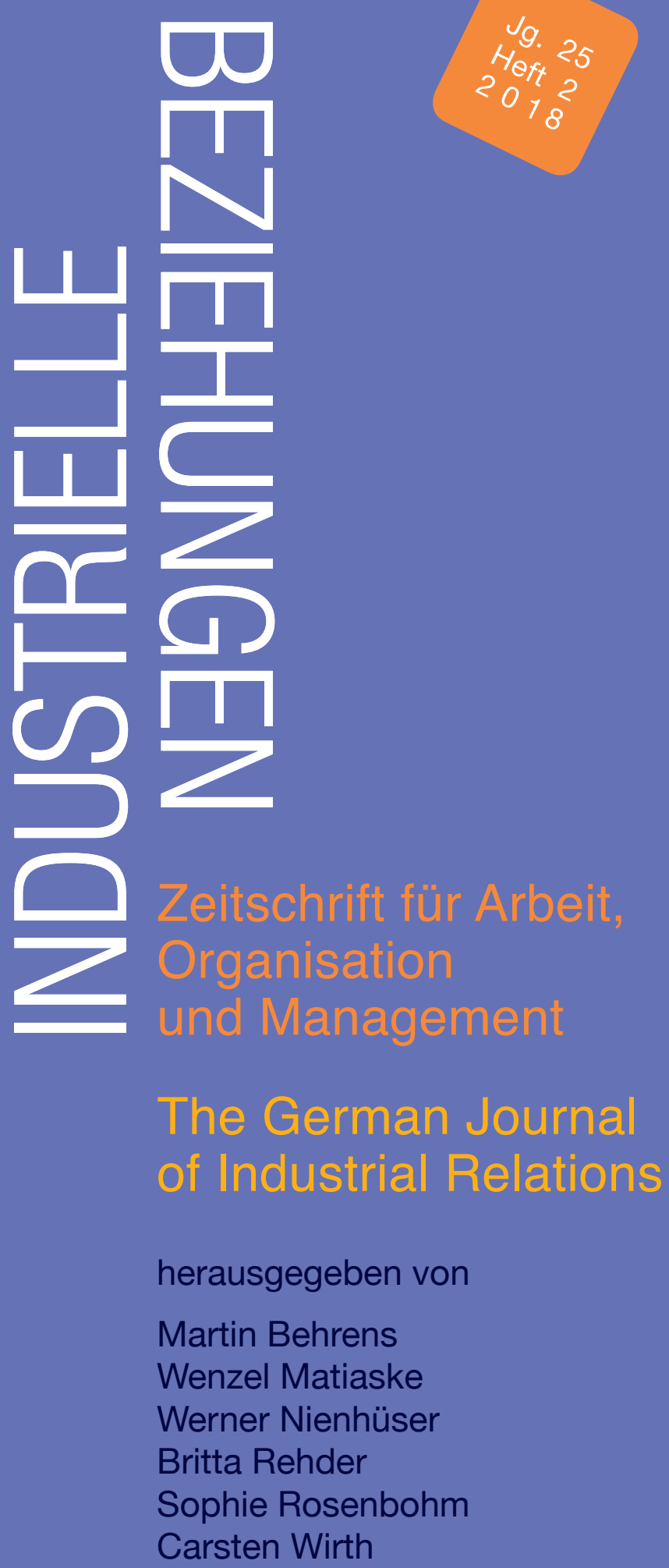

B: Verlag Barbara Budrich 


\section{Inhalt}

Sabrina Zajak, Britta Rehder

Editorial: Soziale Bewegungen und industrielle Beziehungen

Holm-Detlev Köhler, José Pablo Calleja Jiménez

Soziale Bewegungen und gewerkschaftliche Erneuerung in Spanien

Sabrina Zajak, Giulia Gortanutti, Johanna Lauber, Ana-Maria Nikolas

Talking about the same but different?

Understanding social movement and trade union cooperation

through social movement and industrial relations theories

Elisabeth Fink

Transnational Social Movement Unionism als Vitalisierungsstrategie

und Chance für Gewerkschafterinnen?

Das Beispiel des Bekleidungssektors Bangladeschs

\section{Melanie Kryst}

Transnationale Bündnisse von Gewerkschaften und NGOs.

Strategien in Interaktion

\section{Oliver Thünken}

Bewegung im Betrieb.

Organizing-Projekte und die Revitalisierung der industriellen Beziehungen 
Annett Schulze, Wolfgang Hien, Ernst von Kardorff

Der Beitrag der Neuen Sozialen Bewegungen zum Arbeits- und Gesundheitsschutz eine Fallstudie zur Transformation und Verstetigung von Protestkommunikation in (in-)formellen Netzwerken 


\section{Sabrina Zajak, Britta Rehder}

\section{Editorial: Soziale Bewegungen und industrielle Beziehungen}

In den industriellen Beziehungen wurden die Gewerkschaften als soziale Bewegungen wiederentdeckt (vgl. auch Beiträge in Grote \& Wagemann, 2018; Ipsen \& Taipa, 2017). Die Literatur über gewerkschaftliche Revitalisierung und Social Movement Unionism knüpft bisher allerdings nur sehr lose an die theoretischen Konzepte und empirischen Befunde der Bewegungsforschung an (Dörre \& Schmalz, 2014). Dies lässt eine grundlegende und umfassendere Analyse der Beziehungsgeflechte zwischen sozialen Bewegungen und Gewerkschaften auf der einen sowie Versuche der Integration der industriellen Beziehungs- und Bewegungsforschung auf der anderen Seite unterberücksichtigt. Zudem werden soziale Bewegungen meist nur in ihren Interaktionsbeziehungen mit den Gewerkschaften untersucht, nicht aber in ihrem Zusammenspiel mit der betrieblichen Arena der Arbeitsbeziehungen. So wissen wir bisher kaum etwas darüber, ob Forderungen sozialer Bewegungen nach mehr Partizipation und Demokratisierung von Unternehmen dazu beitragen, etablierte Mitbestimmungsstrukturen entweder zu stärken oder aber zu verdrängen bzw. zu ersetzen. Der Austausch und Dialog zwischen den Forschungsgebieten ist in dem Maße relevant, in dem die Bedeutung sozialer Bewegungen im sozialen und politischen Prozess weltweit (wieder) zu wachsen scheint. Nicht wenige Beobachter_innen sehen Kooperationen zwischen sozialen Bewegungen und Gewerkschaften als wichtiges Heilmittel gegen die Auswüchse neoliberaler Globalisierung und deren wirtschaftliche und politische Krisendynamiken ebenso wie als einen Garanten gesellschaftlicher Solidarität und Zusammenhalts. Dabei lassen sich Allianzen in verschiedenen Themenfeldern auch jenseits der Erwerbsregulierung feststellen, z.B. in Handels- und Austeritätsprotesten ebenso wie in den Bereichen (globaler) Umweltregulierung, der Flüchtlingspolitik oder im grenzüberschreitenden Kampf für die Regulierung transnationaler Unternehmen. Gleichzeitig ist es nicht selbstverständlich, dass es zu Bündnissen kommt, und wir wissen bisher wenig darüber wie und unter welchen Bedingungen ideologische Differenzen, unterschiedliche historische Entwick-

* Sabrina Zajak, Institut für soziale Bewegungen, Ruhr-Universität Bochum, Clemensstr. 17-19, 44789 Bochum. E-Mail: sabrina.zajak@rub.de

Britta Rehder, Fakultät für Sozialwissenschaft, Ruhr-Universität Bochum, Universitätsstr. 150, 44801 Bochum. E-Mail: britta.rehder@rub.de 
lungspfade und Konkurrenzverhältnisse zwischen unterschiedlichen Organisationsformen überwunden werden.

Dieses Schwerpunktheft versammelt daher sowohl empirisch als auch konzeptionelltheoretisch angelegte Beiträge zum Thema ,Industrielle Beziehungen und soziale Bewegungen'. Die Beiträge verfolgen dabei verschiedene Ansätze der Theorieintegration. Sie arbeiten auf verschiedene Weise heraus, welche theoretischen Konzepte der Bewegungsforschung besonders anschlussfähig und gewinnbringend für die Perspektive der industriellen Beziehungen sind und was beide Bereiche voneinander lernen können. In der Bewegungsforschung spielen z.B. Theorieschulen eine große Rolle, die im weitesten Sinne den interpretativen oder konstruktivistischen Ansätzen nahestehen (z.B. Framing oder kollektive Identitätskonstruktionen). Diese werden in der Literatur über industrielle Beziehungen bisher nur sehr zögerlich rezipiert. Dort werden eher Ressourcen, Institutionen oder Machtverhältnisse als theoretische Ausgangsbasis genommen. Diese Theoriedivergenz liegt u.a. in der Entwicklung beider Disziplinen begründet. Die Bewegungsforschung als jüngere Disziplin hat sich in ihrer Entstehungsgeschichte explizit gegen strukturalistische Erklärungsansätze und die Betrachtung institutioneller Akteure gewandt. Dies ändert sich aktuell jedoch mit der Rückbesinnung auf gemeinsame Wurzeln in marxistischen Traditionen (della Porta, 2015). So spricht Yon beispielweise von einem „long-awaited homecomming“ (Yon, 2016, S. 82) und bezieht sich damit auf die Wieder-Einbeziehung der Arbeiterbewegung in die Bewegungsforschung. Ebenso lässt sich eine Rückbesinnung der Gewerkschaften auf ihren Ursprung als soziale Bewegung und eine Ausweitung des politischen Mandats über die Arbeitnehmerinteressen hinaus beobachten.

Theoretisch stellen die hier versammelten Beiträge folgende Schwerpunkte in den Vordergrund: Der Beitrag von Köhler und Jiménez zu gewerkschaftlicher Erneuerung in Spanien verwendet den Machtressourcenansatz und das Konzept des „Social Movement Unionism“, um die Zusammenarbeit zwischen Gewerkschaften und sozialen Bewegungen im Kontext der spanischen Wirtschaftskrise zu erklären. Zajak, Gortanutti, Lauber und Nikolas arbeiten die Gemeinsamkeiten in den Theorien der Bewegungsforschung und der Forschung über industrielle Beziehungen heraus. Sie wenden sich gegen Konzepte des Social Movement Unionism, welche in erster Linie auf Ressourcentheorien beruhen. Vielmehr arbeitet der Beitrag die Gemeinsamkeiten und gegenseitigen Anknüpfungspunkte in Hinblick auf Erklärungsfaktoren heraus, die (a) den politökonomischen Kontext, (b) Ressourcenmobilisierung und (c) die Entwicklung gemeinsamer Identitäten und Ideologien berücksichtigen. Der Text von Fink nimmt ebenfalls ressourcenbasierte Theorien des Social Movement Unionism als Ausgangpunkt. Allerdings kritisiert sie die Genderblindheit dieses Ansatzes und ergänzt ihn um eine Geschlechterperspektive. Darüber hinaus plädiert ihre Studie für eine stärkere Berücksichtig spezifischer nationaler und lokaler Kontextfaktoren und gesellschaftlicher Strukturmerkmale, wenn dieser Ansatz auf verschiedene Länder des globalen Südens (in ihrem Fall in Bangladesch) angewendet werden soll. Krysts Beitrag betrachtet die Kooperation von sozialen Bewegungen und Gewerkschaften aus Sicht von Interaktionstheorien. Damit erweitert sie die bisherige Betrachtung von Kooperationen, indem sie diese als gemeinsame Strategien, verstanden als interaktive Sequenzen erfolgsorientierten Handelns, analysiert. Thünkens Beitrag verlässt die Debatte über die Kooperation von Gewerkschaften und sozialen Bewegungen und wendet sich dem Zusammenspiel von sozialer Be- 
wegung und betrieblichen Arbeitsbeziehungen zu. Dabei fokussiert er auf die Analyse neuer Organizing-Ansätze. Schulze, Hien und von Kardorff wenden sich ebenfalls dem Eindringen sozialer Bewegungen in einem Kernbereich der Erwerbsregulierung zu: dem betrieblichen Arbeits- und Gesundheitsschutz. Dabei verwenden die Autor_innen Kommunikations- und Netzwerkansätze aus der Bewegungsforschung. Sie argumentieren, dass der Wandel von Protestkommunikation in kontinuierliche Konfliktkommunikation, die verschiedene Kanäle nutzt, um Gewerkschaften, aber auch den Staat und die Gesellschaft zu erreichen, ausschlaggebend war für den Einfluss sozialer Bewegungen auf ein Kernthema betrieblicher Interessenvertretung.

Empirisch gehen die Beiträge auf unterschiedliche Phänomene des Verhältnisses sozialer Bewegungen und den Akteuren und Strukturen der industriellen Beziehungen ein. Diese werden in verschiedenen Länderkontexten innerhalb und außerhalb Europas diskutiert ebenso wie in ihren transnationalen Zusammenhängen. So untersucht der Beitrag von Köhler und Jiménez die Revitalisierungsstrategien sowie die Chancen und Erneuerungspotentiale, die sich aus Allianzen zwischen den Gewerkschaften und den verschiedenen Strömungen der neuen sozialen Protestbewegungen in der Nachfolge der 'Indignados' (Empört Euch) Bewegung ergeben. Dabei unterscheidet der Beitrag zwischen verschiedenen Formen der Kooperation (Ad-hoc-Koalition, Unterstützungskoalition, Koalition gegenseitiger Unterstützung, nachhaltige Koalition), die sich in der Intensität der Zusammenarbeit, aber auch in ihrem Revitalisierungspotential, unterscheiden. Der Beitrag von Zajak et al. vergleicht die Kooperation von sozialen Bewegungen und Gewerkschaften im Kontext des Anti-Austeritätsnetzwerkes „Alter-Summit“ und der Mobilisierung gegen die transatlantische Handels- und Investitionspartnerschaft mit den USA (TTIP) in Berlin, Oktober 2015. Er zeigt, dass instrumentelle und identitätsbasierte Kooperation keine Gegensätze sind. Es gibt jedoch Situationen, in denen strategische Entscheidungen über Ressourcen und politischen Einfluss entscheidender sind als ideologische Nähe (TTIP) und vice versa (Alter-Summit). Die Autorinnen verweisen darauf, dass es unterschiedliche Entwicklungspfade von Kooperation gibt und diese auch von den sehr kontextspezifischen Faktoren des jeweiligen Kooperationsevents abhängen. Der Beitrag von Fink verlässt den europäischen Kontinent und widmet sich der Kooperation von sozialen Bewegungen (in Form von NGOs) und Gewerkschaften in der bangladeschischen Textilindustrie. Dabei arbeitet sie die Besonderheiten des bangladeschischen Kontexts heraus. Dort galten Kooperationen zwischen NGOs und Gewerkschaften durch die starke Depolitisierung zivilgesellschaftlicher Organisationen auf Grund der finanziellen Abhängigkeit von ausländischen Geberorganisationen lange als kaum realisierbar. Fink weist dennoch auf ein Beispiel der Vernetzung und Solidarisierung von Frauen hin. Damit macht sie die Relevanz von Mehrfachungleichheiten und intersektionalen Problemlagen, die insbesondere Frauen in ihrer Vernetzungsarbeit ausgesetzt sind, deutlich; sie verweist aber auch auf neue Möglichkeiten zur Organisierung, die sich aus einer Kongruenz nationaler und transnationaler Diskurse ergeben. Gemeinsames Handeln auf transnationaler Ebene am Beispiel des European Banana and Agro Industrial Product Action Networks (EURO-BAN) bildet den Fokus im Artikel von Kryst. Es scheint, dass sich die Zusammenarbeit zwischen Gewerkschaften und Bewegungsorganisationen in Form von gemeinsamer Kampagnenarbeit für die Regulierung transnationaler Unternehmen fest etabliert hat. Deswegen geht der Beitrag auch nicht der Frage nach dem Warum der Kooperati- 
on nach, sondern er beschäftigt sich vielmehr mit den spezifischen interaktiven Strategien, mit denen Gewerkschaften und Bewegungen gemeinsam ihre Ziele zu erreichen suchen. Ihre Analyse von EURO-BAN ergibt ein komplexes Zusammenspiel von konfrontativen und kooperativen Strategien sowie die Adressierung multiple Akteure (einzelne Unternehmen, Verbände, Öffentlichkeit und Staat). Damit verdeutlicht dieser Beitrag, wie das gemeinsame Handeln auch die Akteure und ihre Strategiewahl beeinflusst. Das, so ließe sich schlussfolgern, stellt Forschungsansätze in Frage, die von einer recht statischen Betrachtungsweise der Akteure und dem Sinn und Nutzen von Kooperation für nur einen Akteur ausgehen. Der Beitrag von Thünken arbeitet den Bewegungscharakter des Organizing-Ansatzes am Beispiel eines Organizing-Projekts der IG Metall in der Windindustrie heraus. Dabei interessiert er sich insbesondere für die möglichen Komplementaritäten und Reibungsflächen zwischen direkter Partizipation und repräsentativer Interessenvertretungsstruktur. Soziale Bewegung im Betrieb sieht er vor allem in einer stärkeren, gleichwohl häufig auch ungeordneten und nur situativen Beteiligung, Mobilisierung und Aktivierung der Belegschaften. Thünken verweist auch auf die besondere Rolle von Betriebsräten in diesem Prozess. Sie können zu Protagonisten einer beteiligungsorientierten Erweiterung der betrieblichen Interessenvertretung werden. Sie können sich jedoch auch gegen diese Ansätze wenden und damit den Organizing-Prozess ausbremsen. Schulze, Hien und von Kardorff schließlich erinnern uns daran, dass die Frage der Kooperation zwischen Arbeitnehmer_innenvertretung und sozialen Bewegungen nicht neu ist. In ihrer historisch angelegten Fallstudie über den Verein „Arbeit \& Gesundheit e.V.“ arbeiten sie die Rolle sich verfestigender Kommunikationszusammenhänge in informellen Netzwerken heraus, die dazu in der Lage sein können, divergierende organisationale Identitäten zu überwinden. Koalitionen aus Be-

triebsrät_innen und Aktiven der Gesundheitsladenbewegung fungierten als „Knowledge Broker" und Brückenköpfe der Integration von Beschäftigten- und Gesundheitsinteressen. Sie leisteten damit einen wesentlichen Beitrag zur Regulierung des betrieblichen Arbeitsund Gesundheitsschutzes.

\section{Literatur}

Grote, J. R. \& Wagemann, C. (2018). Social Movements and Organised Labour: Passions and Interests. New York: Routledge.

Della Porta, D. (2015). Social Movements in Times of Austerity: Bringing Capitalism Back into Protest Analysis. Cambridge, Malden: Polity Press.

Ibsen, C.L. \& Tapia, M. (2017). Trade union revitalisation: Where are we now? Where to next? Journal of Industrial Relations, 59 (2), 170-19. doi: 10.1177/0022185616677558

Dörre, K. \& Schmalz, S. (2014). Der Machtressourcenansatz: Ein Instrument zur Analyse gewerkschaftlichen Handlungsvermögens. Industrielle Beziehungen., 21 (3), 217-237.

Yon, K. (2016). A long-awaited homecoming: the labour movement in social movement studies. In O. Fillieule \& G. Accornero (Hrsg.), Social movement studies in Europe: the state of the art (S. 54-68). New York, Oxford: Berghahn. 


\section{Holm-Detlev Köhler", José Pablo Calleja Jiménez** Soziale Bewegungen und gewerkschaftliche
Erneuerung in Spanien}

\section{Zusammenfassung}

Die spanischen Gewerkschaften erleiden einen kontinuierlichen Verlust an Mitgliedern und gesellschaftlichem Einfluss. Gleichzeitig haben neue soziale Bewegungen die Rolle des sozialen Protests und der politischen Opposition übernommen. Der vorliegende Beitrag untersucht die Wirkungen und Möglichkeiten von Allianzen zwischen Gewerkschaften und sozialen Bewegungen im Kontext der Debatten um gewerkschaftliche Erneuerung und Bewegungsgewerkschaften. Unter Rückgriff auf den Machtressourcenansatz werden die Chancen und Dilemmata einer verstärkten Zusammenarbeit von sozialen Bewegungen und Gewerkschaften im Kontext der lang anhaltenden Wirtschaftskrise in Spanien ausgelotet. Aus gewerkschaftlicher Sicht repräsentieren die neuen Protestbewegungen gleichzeitig eine Konkurrenz und Bedrohung sowie eine Chance zur Erneuerung durch die Mobilisierung neuer komplementärer Machtressourcen.

Schlagwörter: Gewerkschaften in Spanien, Gewerkschaftliche Erneuerung, Soziale Bewegungsgewerkschaft, Machtressourcen

\section{Social movements and trade union revitalization in Spain}

\section{Abstract}

Spanish trade unions continue to suffer a continuous loss of membership and social influence. At the same time, new social movements have taken up the mantle of social protest and political opposition. This paper examines the effects and possibilities of alliances between trade unions and these new social movements in the context of the debates surrounding trade union revitalization and social movement unionism. In the context of the ongoing economic crisis in Spain, the paper applies the power resources approach to explore opportunities and dilemmas of increased cooperation between social movements and trade unions. From a trade union point of view, the new protest movements represent

* Prof. Dr. Holm-Detlev Köhler, Professor für Soziologie an der Universität von Oviedo, Campus del Cristo, 33006 Oviedo, Spanien. E-Mail: hkohler@uniovi.es

** Prof. Dr. José Pablo Calleja Jiménez, Professor für Soziologie und Sozialarbeit an der Universität von Oviedo, Área de Trabajo Social y Servicios Sociales, Facultad "Jovellanos", 33203 Gijón (Asturias), Spanien. Email: josepablo@uniovi.es

*** Artikel eingegangen: 29.8.2017, revidierte Fassung akzeptiert nach doppelt-blindem Begutachtungsverfahren: 12.3 .2018 
on the one hand competition and threat but on the other hand an opportunity for renewal by mobilizing new complementary power resources.

Key words: trade union revitalization, social movement unionism, Spain, power resources (JEL: $\mathrm{H} 12$, J50, J51, J52)

\section{Einführung}

Die Krise der Gewerkschaften und deren Verhältnis zu den nicht mehr ganz so "neuen" sozialen Bewegungen ist seit Jahrzehnten ein Dauerthema der Sozialwissenschaften. Seit den 1990er Jahren ist dazu aus den angelsächsischen Ländern die Debatte um die strategische Erneuerung der Gewerkschaften (Trade Union Revitalization Studies) gestoßen. Dabei spielt das Konzept der sozialen Bewegungsgewerkschaft (Social Movement Unionism), d.h. die Rückbesinnung der Gewerkschaften auf ihren Ursprung als soziale Bewegung und die Suche nach Allianzen und nachhaltigen Kooperationsformen mit zivilgesellschaftlichen Bewegungen, eine zentrale Rolle. Die aktuellen Schwierigkeiten der spanischen Gewerkschaften, effektive Antworten auf die Herausforderungen der neoliberalen Krisenpolitik seit dem Ausbruch des lang anhaltenden wirtschaftlichen Niedergangs $\mathrm{zu}$ finden, und das gleichzeitige Aufleben neuer sozialer Protestbewegungen unabhängig von den Gewerkschaften haben diese Debatte nach Spanien gebracht.

Der vorliegende Beitrag beruht auf den Ergebnissen eines längeren Forschungsprojektes zu Revitalisierungsstrategien der spanischen Gewerkschaften (Calleja Jiménez, 2016) ${ }^{1}$ und untersucht unter Rückgriff auf den Machtressourcenansatz die Chancen und Erneuerungspotentiale möglicher Allianzen zwischen den Gewerkschaften und den verschiedenen Strömungen der neuen sozialen Protestbewegungen in der Nachfolge der „Indignados“ (Empört Euch)-Bewegung des 15.-Mai 2011. Dazu wird zuerst ein kurzer Überblick über die Situation der spanischen Gewerkschaften gegeben. Im Anschluss werden der Machtressourcenansatz und das Konzept des Social Movement Unionism vorgestellt und auf unseren Untersuchungsgegenstand zugeschnitten. Im folgenden zentralen Teil des Artikels werden die verschiedenen aktiven sozialen Protestgruppen auf ihr Potential für eine Allianz mit den Gewerkschaften und die darin steckenden Möglichkeiten für die Mobilisierung zusätzlicher gewerkschaftlicher Machtressourcen hin untersucht. Der Beitrag schließt mit einem kurzen Ausblick auf Chancen und Widerstände eines Social Movement Unionism in Spanien.

\section{Die spanischen Gewerkschaften}

Gewerkschaften und industrielle Beziehungen in Spanien sind im Wesentlichen das Resultat einer demokratischen Neugründung im Verlauf des Übergangs von der Diktatur zur

1 Im Rahmen dieses Forschungsprojektes haben wir 42 Interviews mit insgesamt 48 Gewerkschaftsvertretern und -vertreterinnen der verschiedenen Organisationsebenen (Industrieverband, Dachverband, lokal, regional, national) und zusätzlich mit einigen Experten, Expertinnen und Mitgliedern von Bürgerinitiativen durchgeführt. 28 der 42 Interviews fielen auf die beiden Mehrheitsgewerkschaften CCOO und UGT. 
Demokratie in den 1970er Jahren. Die sozialistische UGT (Unión General de Trabajadores) hatte die Diktatur im Exil überlebt und erlangte mit politischer Unterstützung der internationalen Sozialdemokratie schnell wieder eine dominante Position. Die zweite historische Gewerkschaft, die anarchosyndikalistische CNT (Confederación Nacional del Trabajo), kehrte dagegen sehr geschwächt und ohne politische Unterstützung aus dem 40-jährigen Exil zurück. Auf der anderen Seite hatten sich mit dem Aufkommen einer demokratischen Untergrundbewegung in den 1960er Jahren neue klandestine Gewerkschaften im Inland gegründet. Dazu gehörten vor allem die kommunistische CCOO (Comisiones Obreras) und die christlich-soziale USO (Unión Sindical Obrera). In dem heftigen Konkurrenzkampf der ersten Jahre nach der Legalisierung der Gewerkschaften (1977) setzten sich schließlich UGT und CCOO als hegemoniale Gewerkschaftsverbände durch (Köhler, 1993). Neben diesen spanischen Gewerkschaftsbünden existieren im Baskenland (ELA und LAB) und in Galizien (CIG) starke regionalistisch-nationalistische Gewerkschaften, während sich in Katalonien trotz einer starken nationalistischen Unabhängigkeitsbewegung die nationalen Bünde UGT und CCOO in ihrer Vormachtstellung behaupten konnten. Dazu trug vor allem die relative Autonomie der regionalen Verbände bei, welche die katalanisch gesinnten Beschäftigtengruppen weitgehend integrieren konnten.

Die Konzentration der überwältigenden Vielfalt gewerkschaftlicher Organisationen auf diese wenigen repräsentativen Verbände in den ersten Jahren des demokratischen Übergangs ist wesentlich einer Politik der demokratischen Stabilisierung und Regierbarkeit geschuldet, die mit dem Gewerkschaftsgesetz von 1985 ein Repräsentativitätskriterium festschrieb, welches den Gewerkschaften mit mehr als 10\% der Betriebsratssitze ein faktisches Repräsentationsmonopol zuteilte. Das seitdem konsolidierte Gewerkschaftssystem ist durch einen relativ niedrigen Organisationsgrad mit 17-18\% der Lohnabhängigen gekennzeichnet, die sich vor allem im öffentlichen Dienst, den traditionellen Industriesektoren und den Banken konzentrieren, wo stabile Arbeitsbedingungen bestehen. Etwa die Hälfte der Beschäftigten beteiligt sich an den alle vier Jahre durchgeführten Betriebsratswahlen, auf die in allen Betrieben mit mehr als fünf Beschäftigten ein Recht besteht. Die in Spanien extrem hohe Anzahl von Mikro-Unternehmen mit weniger als sechs Beschäftigten fällt aus dieser Vertretungsstruktur heraus, eine von den Gewerkschaften seit vielen Jahren angeprangerte gesetzliche Lücke. Das starke Gewicht der gewählten Vertretungen bei relativ geringem Mitgliederstand hat viele Autoren und Autorinnen dazu veranlasst, in Spanien von Wählerstatt Mitgliederorganisationen zu sprechen (Torrecilla, 1990; Valverde, 1991). Die automatische Allgemeinverbindlichkeit (erga omnes) von Tarifverträgen gewährleistet, dass ca. drei Viertel der spanischen Beschäftigten unter Tarifbedingungen arbeiten. Darüber hinaus sind die Gewerkschaften auf allen Ebenen in die politische Konzertierung und Aufsicht wichtiger sozialpolitischer Institutionen (Arbeitsämter, Sozialversicherungen) einbezogen.

Die spanischen Gewerkschaften sind dadurch von Beginn an auf institutionelle Machtressourcen orientiert, da die Wirtschafts- und Arbeitsmarktstruktur den Aufbau organisatorischer und struktureller Machtressourcen erschwert. Die institutionelle Machtbasis beruht auf drei wesentlichen Elementen: den Betriebsratswahlen, den flächendeckenden Branchentarifverhandlungen und der politischen Konzertierung. Rigby und García Calavia (2017) haben diese institutionellen Machtressourcen Durkheimische Institutionen genannt. Wolfgang Streeck (2009) unterschied Durkheimische Institutionen von Williamsonschen Institu- 
tionen. Erstere beruhen nicht auf Eigeninteressen, sondern auf einem gesellschaftlichen Konsens, der durch Regierungen und oft auch durch die Verfassung gesichert wird. Letztere dagegen stützen sich auf die Marktmacht und Stärke der Verbände. Die gesetzlichen Vertretungs- und Verhandlungskompetenzen verleihen den spanischen Gewerkschaften eine marktunabhängigere Stabilität, auf die sie sich lange verlassen konnten.

Die Entwicklung der spanischen Gewerkschaften seit der Demokratisierung kann grob in drei Perioden unterteilt werden. Seit dem Ende der nationalen Sozialpakte zur Konsolidierung des demokratischen Übergangs (1977-1984) bis zur Mitte der 1990er Jahre waren politische Konzertierung und institutionelle Beteiligung nur schwach konsolidiert, und der gewerkschaftliche Einfluss erfolgte eher indirekt über öffentlichen Druck und soziale Mobilisierung. In der darauffolgenden Periode bis zum Ausbruch der Krise 2008 waren die Gewerkschaften sowohl unter den konservativen Volkspartei- (Partido Popular 1996-2004) als auch unter den sozialistischen Regierungen (Partido Socialista Obrero Español 20042011) stark in konzertierte Aktionen und tripartistische Verhandlungsrunden eingebunden. Dadurch wurden sie zu einem politischen Stabilitätsfaktor und konnten ihre institutionellen Machtressourcen ausbauen. Diese institutionelle Machtbasis wurde im Verlauf der neoliberalen Krisenbewältigungspolitik stark ausgehöhlt, insofern die Gewerkschaften weder die empfindlichen Sozial- und Rentenkürzungen verhindern konnten noch von der Regierung mehr als ernstzunehmender Verhandlungspartner wahrgenommen wurden. In einigen Fällen wurden sie direkt geschwächt, indem ihnen öffentliche Gelder gestrichen und Freistellungsregelungen für Betriebsräte reduziert wurden. Darüber hinaus erleiden die Gewerkschaften eine Legitimitätskrise in der spanischen Öffentlichkeit, die sie aufgrund ihrer langjährigen institutionellen Beteiligung für die verfehlte Politik in den spekulativen Immobilienboomjahren (1993-2007) und die überall grassierende Korruption mitverantwortlich macht. Dass es trotzdem immer wieder zu sporadischen Abkommen mit der Regierung bspw. über eine Sozialhilfe für Langzeitarbeitslose (2014) oder die Erhöhung des gesetzlichen Mindestlohns (2017) kommt, wird von Analysten als „Schlagzeilen-Konzertierung“ (Avdagic, Rhodes, \& Visser, 2005, S. 8), „Krisenkorporatismus“ (Urban, 2012, S. 229) oder „fragmentierte symbolische Kooperation“ (Huke \& Tietje, 2014) interpretiert. In einer Defensivhaltung wird versucht, die Verluste so gering wie möglich zu halten und institutionelle Positionen für den lang ersehnten Aufschwung zu retten.

Der Niedergang von gewerkschaftlicher Macht und Einfluss ist ein globales und europäisches Phänomen mit zahlreichen externen und internen Gründen (Gumbrell-McCormick \& Hyman, 2013; Lehndorff, Dribbusch, \& Schulten, 2017). Zu ersteren zählen die Folgen der ökonomischen Globalisierung, der wirtschaftliche Strukturwandel, die neoliberale Hegemonie in der Politik und den öffentlichen Diskursen, die Individualisierung und der Verlust der Arbeiterklassenidentität sowie die Prekarisierung der Arbeitsmärkte. Intern sind die Gewerkschaften oft durch bürokratische Prozesse und Rituale (Beschlusslage, Sitzungen, Antragsverfahren, Gremien, Wahlen, Kongresse) geprägt, die es ihnen nicht erlauben, effektiv und flexibel auf die neuen Herausforderungen zu reagieren. Der Mangel an einer effektiven Widerstandsstrategie setzt eine Abwärtsspirale gewerkschaftlicher Schwächung in Gang (Turner, 2004, S. 5), in der es zur Abwanderung enttäuschter Mitglieder und fortschreitender Machtverschiebung zugunsten des Kapitals und den diesem wohlgesonnenen Regierungen kommt. Diesem nachhaltigen Trend zur Schwächung der Gewerkschaften in 
Betrieb und Gesellschaft kann gemäß den Studien zur Revitalisierung der Gewerkschaften allein durch eine gezielte strategische Erneuerung begegnet werden. Diese bestünde in einer koordinierten Mobilisierung verschiedener Machtressourcen, die in einem kumulativen Prozess zu einer Wiedererstarkung der erneuerten gewerkschaftlichen Organisationen führten (Calleja, 2016).

Die Notwendigkeit einer strategischen Erneuerung für die spanischen Gewerkschaften zeigt sich zuallererst in rückläufigen Mitgliedszahlen. Nach inoffiziellen Angaben haben die beiden großen Gewerkschaften seit dem Ausbruch der Krise ca. ein Fünftel ihrer Mitgliedschaft eingebüßt (Abbildung 1). Das staatliche Meinungsforschungsinstitut CIS (Centro de Investigaciones Sociológicas) bestätigt zudem in regelmäßigen Umfragen den Vertrauensverlust der Gewerkschaften in der Bevölkerung, die den Arbeitnehmerorganisationen gemeinsam mit den politischen Parteien die niedrigsten Werte bei der Wertschätzung gesellschaftlicher Institutionen zuteilt (CIS, 2015). Die Präsenz der Gewerkschaften reduziert sich immer stärker auf wenige Sektoren mit traditionell hohem Organisationsgrad, während sich ein wachsender Teil prekärer, jugendlicher Beschäftigter und Arbeitsloser nicht von den Gewerkschaften vertreten fühlt und seine sozialen Forderungen und Proteste viel stärker in den neuen sozialen Bewegungen ausdrückt (Antón, 2007; López Calle, 2007). Diejenigen, die gewerkschaftliche Unterstützung in den prekären Arbeitsmarktsegmenten am nötigsten hätten, sind kaum gewerkschaftlich organisiert und vertreten.

Abbildung 1: Veränderung der Mitgliedszahlen von CCOO und UGT 2009-2015

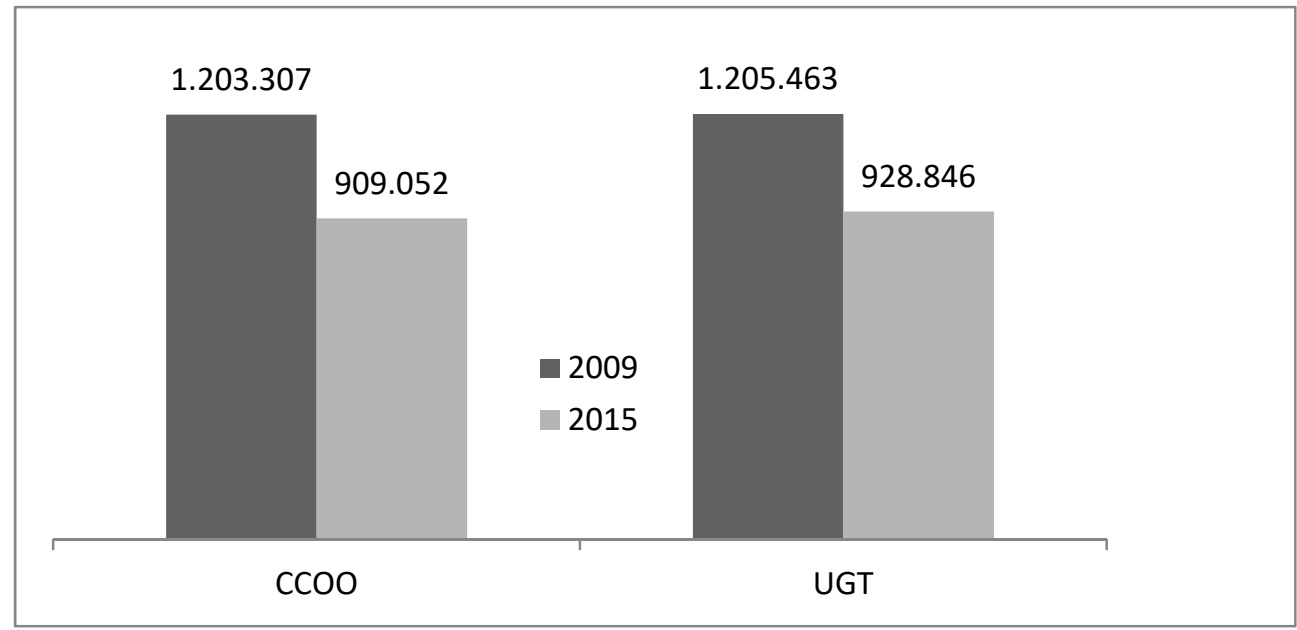

Quelle: Expansión (7.3.2016) auf Basis von Angaben der Dachverbände

Zusammenfassend befinden sich die spanischen Gewerkschaften vor der Notwendigkeit einer strategischen Reorientierung und Erneuerung, da sich ihre traditionellen Machtinstrumente wie die punktuelle Mobilisierung in Generalstreiks und Demonstrationen und die politische Konzertierung zunehmend als stumpf und wirkungslos erweisen; eine Tendenz, die sich auch in anderen Mittelmeerländern beobachten lässt (Lehndorff et al., 2017). Die Generalstreiks gegen die sozialen Kürzungen und die Arbeitsmarktreformen 2010 und 2012 
hatten keinen spürbaren Einfluss auf die neoliberale Krisenpolitik. Vertrauensverlust und Distanz zur Bevölkerung und Arbeiterschaft sind Ausdruck der gewerkschaftlichen Krise. Auf der anderen Seite haben sich neue soziale Bewegungen zum Sprachrohr der sozialen Proteste entwickelt und spürbare politische Erfolge inkl. des Aufbrechens des verkrusteten ZweiParteien-Systems in Form der neuen Protestpartei Podemos (Wir Können) erzielt. Im Folgenden analysieren wir die Chancen einer gewerkschaftlichen Erneuerung durch eine Zusammenarbeit mit den neuen sozialen Protestbewegungen. Dazu greifen wir auf die theoretischen Debatten der sog. Labor Revitalization Studies (Frege \& Kelly, 2004; Hälker \& Vellay, 2007) und den Machtressourcenansatz (Gumbrell-McCormick \& Hyman, 2013) zurück.

\section{Gewerkschaften als soziale Bewegung}

Seit Beginn der Debatten über Strategien der gewerkschaftlichen Erneuerung wird argumentiert, dass sich die Gewerkschaften wieder in soziale Bewegungen zurückverwandeln müssen (Frege et al., 2004, S. 137). Historisch haben sich die Gewerkschaften als soziale Bewegungen herausgebildet, wenn auch oft unter Einfluss bestehender ständischer Berufsverbände, und in der soziologischen Literatur erscheinen sie häufig als Paradebeispiel für „alte“ soziale Bewegungen. Demgegenüber zeichnen sich „neue“ soziale Bewegungen durch vielfältige Themenschwerpunkte jenseits des traditionellen Klassenkonflikts (Touraine, 1981; Offe, 1985; Laraña et al., 1994) und zeitgemäßere „flüchtige“ Formen und Diskurse aus (Baumann, 2003). Sie können aktuelle soziale Probleme und Debatten schnell aufnehmen und in kollektive Aktionen umsetzen. Autoren wie Turner \& Kilian (1987) betonen die flexiblen Organisationsformen und breiten Bündnisse oft heterogener Akteure dieser neuen Bewegungen gegenüber den stark institutionalisierten Formen kollektiver Aktion der Gewerkschaften. So analysiert Alain Touraine (1981) soziale Bewegungen als kollektive Akteure, deren Handeln auf den Kampf um Historizität gerichtet ist, d.h. um die Neudefinition der in einer Gesellschaft dominanten Normen und Interpretationsmuster. Ähnlich argumentiert Diani (2015), der soziale Bewegungen als dynamischen Formierungsprozess verschiedener sozialer Akteure begreift, die sich gemeinsam auf einer Seite eines sozialen Konflikts vereinen. Soziale Bewegungen umfassen dabei viele Organisationen, die sich um ein soziales Ziel bündeln. Die internen Beziehungen können sowohl in solidarischer Kooperation wie in Konkurrenz bestehen (Zald \& McCarthy, 1980). In aktuellen Debatten stehen das Internet und die Organisation in sozialen Netzen im Vordergrund, für Castells (2012) die zentrale und geeignete Technologie und ein demokratisches Instrument zur Selbstorganisation, Koordinierung, Mobilisierung und Entscheidungsfindung.

Eine Erneuerung in Form einer Rückbesinnung auf den Ursprung als soziale Bewegung erfordert von den Gewerkschaften eine Ausweitung des politischen Mandats über die Arbeitnehmerinteressen hinaus zu denjenigen der Arbeiterschaft als Bürgerinnen und Bürger. Neue Diskursformen, Organisationskulturen und politische Ziele müssten Gegenstand sowohl interner Debatten wie einer strategischen Öffnung zu Allianzen mit neuen sozialen Protestbewegungen werden. Vor über 20 Jahren forderte Peter Waterman (1993) bereits eine gewerkschaftliche Öffnung zu neuen postmaterialistischen Werten, wie sie von Bürgerbewegungen, Frauen-, Ökologie-, sexuellen Befreiungs-, oder basisdemokratischen Grup- 
pen vertreten werden. Amanda Tattersal (2011) zufolge bedingt der Grad einer gegenseitigen Öffnung den beiderseitigen politischen Gewinn.

Gumbrell-McCormick \& Hyman (2013, S. 30f) unterscheiden hinsichtlich des Potentials zur gewerkschaftlichen Revitalisierung vier traditionelle und drei komplementäre Machtressourcen ${ }^{2}$. Die traditionellen Machtressourcen umfassen strukturelle Macht (Stellung auf dem Arbeitsmarkt und im Produktionsprozess), gesellschaftliche Macht (personelle und materielle Ressourcen), Organisationsmacht (Mitglieder und deren Bereitschaft zu kollektivem Handeln) und institutionelle Macht (Beteiligung im politischen System, Korporatismus). Diese traditionellen Machtressourcen, welche die Gewerkschaften in den fordistischen Jahrzehnten des vergangenen Jahrhunderts prägten, sind seit vielen Jahren einem kontinuierlichen Erosionsprozess ausgesetzt. Um diesen Machtverlust zu kompensieren und den Trend umzukehren, ist diesen Autoren zufolge die Mobilisierung zusätzlicher komplementärer Machtressourcen notwendig, die nicht unbedingt neu sind, wohl aber lange vernachlässigt wurden. Dazu gehört in erster Linie die diskursive oder moralische Macht, die Fähigkeit der Bevölkerung, die sozialpolitischen Ziele der Gewerkschaften zu vermitteln und effektive Strategien zu deren Erreichung bereitzustellen. Die Frage, wozu sind wir eigentlich da? (Hassel, 2012) stünde im Mittelpunkt interner und öffentlicher Debatten über unterschiedliche Kommunikationsmedien. Die Rückgewinnung moralischer Macht ist der Ausgangspunkt für eine Erweiterung der Mitgliederbasis und der Mobilisierungsfähigkeit unter Einbezug neuer sozialer Gruppen. Der Aufbau diskursiver Machtressourcen geht Hand in Hand mit der zweiten komplementären Machtressource, der Koalitionsmacht bzw. der strategischen Zusammenarbeit mit nahestehenden Bürgergruppen und sozialen Organisationen. Eine dritte komplementäre Machtressource ist die strategische oder logistische Macht, die Fähigkeit in Zeiten knapper Ressourcen diese intelligent einzusetzen und klare Prioritäten zu setzen (ein zentraler Punkt in der angelsächsischen Organizing-Debatte). Die Rückkehr in die Gesellschaft in Form strategischer Allianzen mit nahestehenden sozialen Bewegungen gehört zum ursprünglichen Repertoire der Gewerkschaften als „sekundäres“ Aktionsfeld (Frege, Heery, \& Turner, 2004, S. 138) neben den schon von den Webbs ([1894], 1990) ausgemachten drei primären Instrumenten der gegenseitigen Versicherung, der Tarifverhandlungen und der legal-normativen Rechtsgarantien.

Die Mobilisierung dieser komplementären und lange Zeit vernachlässigten Machtressourcen ist eine zentrale Quelle für gewerkschaftliche Revitalisierungsstrategien, zumal sie sich direkt auf die Stärkung der traditionellen Machtressourcen auswirkt. Die dezidierte Suche nach Allianzen mit sozialen Bürgerbewegungen bildet den Kern einer so verstandenen Erneuerungsstrategie, und die Vielfalt der Protestbewegungen, die sich in den letzten Jahren in Spanien gegen die neoliberale Austeritätspolitik gebildet haben, erscheint dafür als strategische Gelegenheit (Tarrow, 2004). In seiner klassischen Studie sprach Allan Flanders (1970, S. 15) vom Doppelcharakter der Gewerkschaften als Vertreter von Gruppeninteressen und als soziales „Schwert der Gerechtigkeit“. Dieses Schwert könnte, so die zentrale

2 Wir ziehen den Machtressourcenansatz von Gumbrell-McCormick \& Hyman, insbesondere deren Unterscheidung zwischen traditionellen und komplementären Machtressourcen, demjenigen von Dörre et al. (vgl. Brinkmann et al., 2008; Schmalz \& Dörre, 2014; Huke \& Tietje, 2014) vor, da er expliziter auf das Potential zu gewerkschaftlicher Erneuerung abstellt. 
These der Revitalisierungsstudien, durch einen Strategiewandel neu geschärft und dadurch der schleichende Machtverlust aufgehalten werden.

Warum tun sich die Gewerkschaften so schwer, diesen Strategiewandel zu vollziehen? Auch in dieser Frage spielen interne und externe Faktoren eine Rolle. Eine lang eingeübte und stark routinisierte Organisationspraxis zu ändern, ist nur mit einer starken Führung und klarem politischem Willen möglich. Solange alle dem Niedergang zusehen und darauf warten, dass andere den ersten Schritt tun, verlängert sich allein die Lethargie. Zweitens müssen neue Vertrauensverhältnisse aufgebaut werden zu Gruppen und Bewegungen, die den großen Gewerkschaften misstrauisch und distanziert gegenüberstehen. Eine Hinwendung zu sozialen Protestbewegungen beinhaltet für die Gewerkschaften eine viel stärker konfliktorientierte Politik und dadurch ein Aufgeben einiger institutionalisierter „Insider“-Positionen (Byford, 2009). Dies ist nach langen Jahren des dominanten Vertrauens in gesicherte institutionelle Machtressourcen ein schwieriger und risikobeladener Prozess. Drittens ist die strategische Wahl der Koalitionspartner auf Seiten der neuen Protestbewegungen alles andere als einfach. Viele dieser Gruppen sind kurzlebig und schwach organisiert und für dauerhafte produktive Allianzen ungeeignet.

\section{Strategische Allianzen mit wem?}

Die verstärkte und dauerhafte Kooperation mit zivilen Bürger- und Protestgruppen birgt für die spanischen Gewerkschaften im aktuellen Kontext einer ungerechten Verteilung der Lasten der Wirtschaftskrise, einer wachsenden sozialen Ungleichheit, einer dauerhaften Massenarbeitslosigkeit und Prekarisierung der Arbeitsmärkte sowie einer vielschichtigen Staatskrise mit korrupten Apparaten und regionalen Unabhängigkeitsbestrebungen ein großes Potential, an neue Mitgliedsgruppen, erfolgreichere Mobilisierungs- und kollektive Aktionsformen, ein aufgewertetes Image und andere Erneuerungsressourcen zu gelangen. Gleichwohl existieren gerade im spanischen Fall auf beiden Seiten, den großen Gewerkschaftsbünden und den sozialen Protestbewegungen, hohe Misstrauensbarrieren und in deren Gefolge Widerstände, sich ernsthaft anzunähern (Kloosterboer, 2007) ${ }^{3}$. Hinzu kommt, dass viele kleinere regionale und radikalere Gewerkschaften stark in den sozialen Protestbewegungen mitwirken und wenig Interesse an einer Zusammenarbeit mit den großen institutionalisierten Mehrheitsgewerkschaften haben.

Amanda Tattersall $(2005 ; 2011)$ hat mit Blick auf ein effektives gewerkschaftliches Erneuerungspotential eine Typologie von Koalitionen zwischen Gewerkschaften und sozialen Protestgruppen erarbeitet und warnt vor oberflächlichen Scheinallianzen oder „Briefkopfkoalitionen“ (Tattersall, 2011, S. 75), die nichts zur Stärkung und Erneuerung der Gewerkschaften beitragen. Die vermeintliche Stärke der Koalition wird dabei mit der Anzahl der unterzeichnenden Organisationen verwechselt, ohne dass dahinter ein verbindlicher Kompromiss und effektive Zusammenarbeit stünden. Form und Partnerwahl erscheinen so als eine ent-

3 In den Interviews mit Aktivisten und Aktivistinnen der Protestgruppen wurde immer wieder betont, dass es den Gewerkschaften nur darum gehe, bei Demonstrationen in der ersten Reihe mit ihren Fahnen zu erscheinen, um dann doch wieder mit Arbeitgeberinnen und Arbeitgebern und Regierungen Konzessionsverhandlungen einzugehen. 
scheidende strategische Wahl für Gewerkschaften auf der Suche nach neuen Machtressourcen.

Tabelle 1: Typologie von Koalitionen zwischen Gewerkschaften und Bürgerbewegungen

\begin{tabular}{|c|c|c|c|c|}
\hline & $\begin{array}{l}\text { Ad hoc } \\
\text { Koalition } \\
\end{array}$ & Unterstützungskoalition & $\begin{array}{l}\text { Koalition gegenseitiger } \\
\text { Unterstützung } \\
\end{array}$ & $\begin{array}{l}\text { Nachhaltige } \\
\text { Koalition }\end{array}$ \\
\hline $\begin{array}{l}\text { Gemeinsames } \\
\text { Interesse }\end{array}$ & $\begin{array}{l}\text { Spezifisches } \\
\text { Thema/Event } \\
\text { Auf Initiative der } \\
\text { Gewerkschaft } \\
\text { oder Bürger- } \\
\text { gruppe }\end{array}$ & $\begin{array}{l}\text { - Spezifisches } \\
\text { Thema/Event } \\
\text { Von Gewerkschaften re- } \\
\text { lativ unabhängiges The- } \\
\text { ma }\end{array}$ & $\begin{array}{l}\text { - Gemeinsames Interesse } \\
\text { der beteiligten Organi- } \\
\text { sationen }\end{array}$ & $\begin{array}{l}\text { - Themen aus der } \\
\text { Arbeitswelt }\end{array}$ \\
\hline $\begin{array}{l}\text { Struktur und } \\
\text { Strategie }\end{array}$ & $\begin{array}{l}\text { Episodische } \\
\text { Beteiligung } \\
\text { Taktische, nicht } \\
\text { strategische } \\
\text { Beteiligung }\end{array}$ & $\begin{array}{l}\text { - Kurzfristige Koalition } \\
\text { Entscheidungen } \\
\text { - Begrenzte, informelle Be- } \\
\text { teiligung }\end{array}$ & $\begin{array}{l}\text { Gemeinsame Organi- } \\
\text { sierung und Entschei- } \\
\text { dungen, gegenseitige } \\
\text { Vertrauensbildung } \\
\text { Mittelfristige } \\
\text { Orientierung } \\
\text { Politische und organi- } \\
\text { satorische Ähnlichkei- } \\
\text { ten der beteiligten Or- } \\
\text { ganisationen } \\
\end{array}$ & \begin{tabular}{|l} 
- Dezentralisierte \\
Beziehungen zwi- \\
schen Mitgliedern \\
der Gewerkschaf- \\
ten und Bürger- \\
gruppen \\
Langfristige Orien- \\
tierung, gegensei- \\
tige Stärkung
\end{tabular} \\
\hline $\begin{array}{l}\text { Organisation/ } \\
\text { Beteiligung der } \\
\text { Gewerkschaft }\end{array}$ & $\begin{array}{l}\text { - Instrumentelle } \\
\text { Beteiligung } \\
\text { - Campaign }\end{array}$ & $\begin{array}{l}\text { - Hauptamtliche Gewerk- } \\
\text { schaftsvertreterInnen } \\
\text { ohne direkte Beteiligung } \\
\text { der MitgliederInnen } \\
\text { - } \text { Rent-a-crowd }\end{array}$ & $\begin{array}{l}\text { - Gemeinsame Mobilisie- } \\
\text { rung und Beteiligung } \\
\text { der Mitgliederlnnen, } \\
\text { oft Doppelmitglied- } \\
\text { schaften } \\
\text { Greater buy-in }\end{array}$ & $\begin{array}{l}\text { - Aktive Basisbetei- } \\
\text { ligung, Kooperati- } \\
\text { on auf allen Ebe- } \\
\text { nen } \\
\text { - Significant buy-in, } \\
\text { incl. finanzieller } \\
\text { Ressourcen }\end{array}$ \\
\hline
\end{tabular}

Quelle: Eigene Zusammenstellung nach Tattersall (2005)

Die Auswirkungen der neoliberalen Krisenpolitik mit empfindlichen Kürzungen im Sozialund Gesundheitswesen und Einschnitten in den Arbeitnehmerrechten haben in den vergangenen Jahren zu mehreren Erfahrungen mit gemeinsamen Aktionen von Gewerkschaften und zivilgesellschaftlichen Gruppen geführt. So organisierten die Gewerkschaften im Jahr 2012 einen „Sozialgipfel“, ein Zusammenschluss von ca. 150 Organisationen und Bürgergruppen, dessen politische Wirkung allerdings nicht die Erwartungen erfüllte und dessen Aufrufe kaum Widerhall fanden. Nachdem es nicht gelungen war, die gewerkschaftsfeindliche Arbeitsmarktreform (2012) zu verhindern, fiel dieses Organisationsbündnis wieder auseinander. Im Sinne Tattersalls kam der Sozialgipfel nicht über den Charakter einer „Unterstützungskoalition“ hinaus.

Sehr viel erfolgreicher waren die „Bürgerfluten“ (mareas ciudadanas) in den von Kürzungen und Privatisierungen bedrohten öffentlichen Dienstleistungssektoren (Gesundheit, Erziehung, Verwaltung) (Huke \& Tietje, 2014b; Huke, 2017). In diesen „Koalitionen gegenseitiger Unterstützung“" schlossen sich die gewerkschaftlich organisierten Beschäftigten mit sozialen Organisationen und Nutzergruppen zu gemeinsamen Aktionen zusammen, um so bspw. die Privatisierung von Krankenhäusern zu verhindern. Die Organisationsform war sehr inklusiv, flexibel und horizontal unter breiter Basisbeteiligung. Auch wenn die The- 
men eher defensiv waren und einige Autoren und Autorinnen eine korporativistische Tendenz ausmachten (Gil, 2016), können die Bürgerfluten als erfolgreiche Zusammenarbeit von gewerkschaftlichen mit zivilen Organisationen angesehen werden. Für die Gewerkschaften beinhalten sie ein klares Erneuerungspotential, indem sie auch traditionelle Machtressourcen, wie z.B. die Positionen in Tarifverhandlungen und in der Öffentlichkeit, insgesamt stärken. In mancher Hinsicht erfüllen sie sogar das Kriterium einer „,nachhaltigen Koalition“, insofern es ihnen gelungen ist, Erfahrungen kollektiver Protestformen gegen öffentliche Sparpolitik zu bündeln und als Aktionsrepertoire zu speichern. Problembeladen sind allerdings häufig die Beziehungen zwischen den in diesen Sektoren starken berufsständischen Organisationen (Ärzte-, Pflegepersonal-, Lehrer-, Richter-, Beamtenverbände) und den großen „Klassengewerkschaften“. Die Beschränkung auf Defensivforderungen im öffentlichen Dienst bildet eine weitere Barriere hinsichtlich eines breiten gewerkschaftlichen Erneuerungspotentials. Weder kommt es zu proaktiven Initiativen für Strukturreformen im öffentlichen Dienst, noch bilden sich ähnlich inklusive Koalitionen in der privaten Wirtschaft. Zurzeit befinden sich die „Bürgerfluten“ in einer Latenzphase, bereit erneut aktiv zu werden, falls sich die Angriffe auf die öffentlichen Dienste wiederholen.

Eine weitere Erfahrung gemeinsamer Mobilisierung gegen das neoliberale Krisenmanagement sind die seit mehreren Jahren in vielen Städten durchgeführten „Märsche für Menschenwürde" (marchas de la dignidad) unter Beteiligung vieler Protestgruppen, die sich im Gefolge der „Empört-Euch“-Bewegung 2011 (Indignados), auch Bewegung 15. Mai genannt, gebildet hatten. Hier zeigten sich deutlich die Probleme und erwähnten Misstrauensbarrieren gegenüber einer Annäherung zwischen den neuen Protestbewegungen und den großen Gewerkschaften. Die Märsche werden sehr stark von radikaleren kleinen Gewerkschaften und linken Gruppen unterstützt, die den beiden Mehrheitsgewerkschaften CCOO und UGT sehr kritisch gegenüberstehen. Insgesamt war die Bewegung 15. Mai, die monatelang die zentralen Plätze der spanischen Städte in Form eines basisdemokratischen Protests gegen die korrupte politische Klasse und die sozial ungerechte Politik besetzt hielt, explizit auch gegen die großen Gewerkschaften gerichtet. Der Slogan „Sie repräsentieren uns nicht“ und die Forderung nach einer von Grund auf erneuerten Demokratie schließt die institutionell eingebundenen Gewerkschaften als mitverantwortlich für die Krise des demokratischen Systems ein (Huke, 2017). Die Märsche sind somit eine „nachhaltige Koalition“ vieler kleiner radikaler, lokaler oder regionaler Gewerkschaftsgruppen außerhalb der beiden großen Mehrheitsgewerkschaften mit den heterogenen Protestgruppen, an denen sich Mitgliedsgruppen der Mehrheitsgewerkschaften allenfalls sporadisch beteiligen. Während die kleinen radikalen Gewerkschaften von der aktiven Mitarbeit in den Protestbewegungen profitieren und gleichzeitig ihre Erfahrungen mit Mobilisierungen und Protestaktionen einbringen, vertieft sich der Graben zwischen diesen Bewegungen und den Mehrheitsgewerkschaften.

Neben diesen nationalen Erfahrungen mit gewerkschaftlich-zivilgesellschaftlichen Koalitionen existieren zahlreiche lokale Plattformen, in denen sich Belegschaften mit lokalen Bürgergruppen zusammenschließen. Dabei geht es entweder um lokale politische Konflikte oder um Arbeitskonflikte, bei denen die Arbeitsplätze bestimmter Werke oder Filialen bedroht sind ${ }^{4}$. In diesen Fällen mobilisieren die Belegschaften, oft in klarer Diskrepanz zu den

4 Beispiele sind die Plattformen „Arbeiterversammlung im Kampf“

(https://www.facebook.com/asambleadetrabajadoresenlucha/) oder „Coca Cola im Kampf“ 
auf institutionelle Verhandlungen konzentrierten Gewerkschaften, die lokale Bevölkerung und Bürgergruppen, um darüber einen verstärkten Druck auf Unternehmen und Regierungen auszuüben. Dies sind klare Beispiele dafür, wie zivilgesellschaftliche Koalitionen die geschrumpfte Machtbasis der Gewerkschaften ausweiten und erneuern können, ein Beispiel für „nachhaltige Koalitionen“ auf lokaler Ebene. Die Strategien dieser Belegschaften erinnern in vielem an das angelsächsische Organizing, obwohl die Initiative hier stärker auf autonome, nicht gewerkschaftlich dominierte Machtressourcen zielt. Wie Abbildung 2 zeigt, ist in den Arbeitskonflikten der Krisenjahre auch die Zahl unbefristeter Erzwingungs- oder Kampfstreiks ${ }^{5}$ gestiegen, die häufig auf die Solidarität der lokalen Bevölkerung angewiesen sind, da die meisten spanischen Gewerkschaften nicht über Streikkassen verfügen.

Abbildung 2: $\quad$ Anzahl der Streiks mit einer Dauer von mehr als 30 Tagen

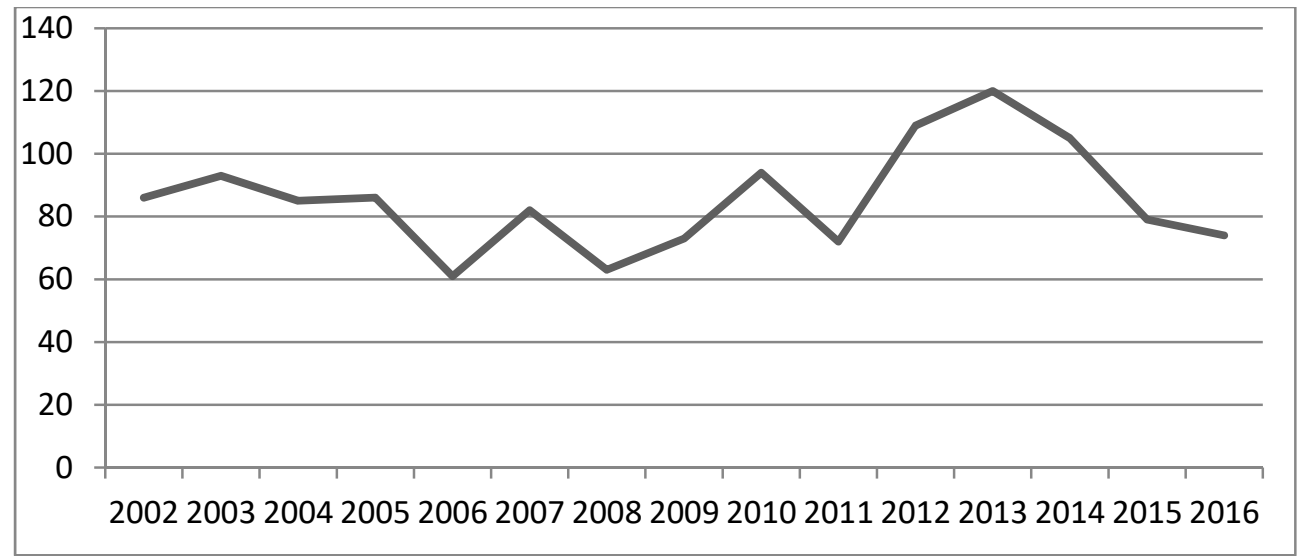

Quelle: Eig. Darstellung gemäß der offiziellen Streikstatistik des Ministeriums für Beschäftigung und Soziales

Ein illustratives Beispiel ist der Streik der Auftragsfirmen der Telefongesellschaft Movistar gegen die prekären Arbeitsverhältnisse 2016, der von der Kooperativbank Coop57 durch einen zinslosen Kredit finanziell unterstützt wurde. Die Belegschaften organisierten gemeinsam mit sozialen Bürgergruppen ein Benefiz-Sportfest, über dessen Einnahmen der Kredit zurückgezahlt wurde (Oñederra, 2016). Der darüber hinaus eingefahrene Überschuss von mehreren Tausend Euro dient als Fonds zur Unterstützung anderer Arbeitskämpfe.

Derartige lokale Koalitionen zwischen Belegschaften und Bürgergruppen unter selektiver Beteiligung lokaler Gewerkschaftsgruppen sind in den Krisenjahren durchaus häufig aufgetreten und haben die Arbeitswelt als gesellschaftliches Konfliktfeld wieder stärker ins öffentliche Bewusstsein gehoben. Sie sind über die sozialen Netzwerke auch untereinander

(https://www.facebook.com/groups/837762996256846/?fref=ts). Vgl. auch Köhler \& González Begega (2016).

5 Erzwingungs- oder Kampfstreiks sind im Unterschied zu den üblichen Demonstrationsstreiks auf die Erreichung eines bestimmten, klar benannten Ziels gerichtet (bspw. den Erhalt eines Standortes) und daher oft nicht verhandelbar. Sie enden kaum mit einem Kompromiss, sondern mit Sieg oder Niederlage der im Streik mobilisierten Belegschaften und sozialen Gruppen (Gallas \& Nowak, 2012). 
verbunden, einen nachhaltigen Einfluss auf eine gewerkschaftliche Erneuerung ist bislang jedoch nicht sichtbar. Die 2018 wieder aufgelebten „Märsche gegen die Prekarität“ (Marchas contra la precariedad), eine Plattform vieler Beschäftigtenkollektive, die regelmäßig Protestaktionen in vielen Städten gegen die prekären Arbeitsverhältnisse organisieren, finden ebenfalls ohne Beteiligung der großen Gewerkschaften und in klarer Distanz zu diesen statt.

Unsere begleitende Analyse der Beziehungen und Spannungen zwischen sozialen Protestbewegungen und Gewerkschaften seit dem Ausbruch der Krise und dem Auftreten der Indignados-Bewegung zeigt ein sehr uneinheitliches und vielschichtiges Bild. Das sehr heterogene und komplexe Panorama sozialer Bewegungen in Spanien erfordert von den Gewerkschaften strategische Wahlentscheidungen auf der Suche nach Koalitionspartnern, mit denen sie wesentliche politisch-ideologische Ziele teilen. Die neuen sozialen Protestbewegungen im Gefolge der 15. Mai-Bewegung haben viele Menschen wachgerüttelt und ein breites, oft diffuses Amalgam von politischen Forderungen hervorgebracht, die sich aber um eine gemeinsame Grundüberzeugung gruppieren: Die Politik darf sich nicht der wirtschaftlichen Macht unterordnen. Diese Grundüberzeugung ist eine hervorragende Ausgangsbasis für Koalitionen mit den Gewerkschaften. Nichtsdestotrotz werden die großen Gewerkschaften in vielen Teilen der Bevölkerung als den Wirtschaftsinteressen ergebene Organisationen und Teil des politischen Systems wahrgenommen. Eine Annäherung an die inzwischen sehr verstreuten neuen Protestbewegungen könnte für sie wichtige neue Mitgliederpotentiale in der jungen, von der Prekarisierung der Arbeitsmärkte besonders betroffenen, Bevölkerung erschließen und den notwendigen Input für eine personelle und organisatorische Erneuerung liefern. Gruppen wie „Jugend ohne Zukunft“ (Juventud sin Futuro) und das „Büro für Prekäre“ (Oficina Precaria) gehörten zu den Initiativgruppen der 15. Mai-Bewegung und thematisierten arbeitsmarkt- und gewerkschaftspolitische Themen, ohne jemals in einen ernsthaften Kontakt zu den Arbeitnehmerorganisationen getreten zu sein. Viele ihrer Aktivistinnen und Aktivisten kritisierten das Desinteresse der Gewerkschaften an den spezifischen Jugendproblemen in Betrieb und Arbeitsmarkt und sind heute in Podemos oder anderen neuen politischen Gruppen aktiv.

Unter den aktiven neuen sozialen Protestgruppen bieten sich unserer Analyse zufolge zumindest vier Strömungen als potentielle Koalitionspartner für Gewerkschaften an. Im Kampf um soziale Gerechtigkeit gegen die Folgen der Wirtschafts- und Finanzkrise haben die Plattformen gegen Wohnungszwangsräumungen aufgrund nicht bezahlter Hypotheken (Plataformas de Afectados por la Hipoteca) große Unterstützung erfahren. Die derzeitige Bürgermeisterin von Barcelona und Vorsitzende der katalonischen Podemos Partei Ada Colau gehört zu den Gründerinnen dieser Bewegung. In den Jahren des spekulativen Immobilienbooms (1993-2007) haben die Banken mit großzügigen Angeboten viele Menschen zum Wohnungskauf animiert und sind nun häufig zu Eigentümern dieser Wohnungen geworden, da die Familien die Hypotheken nicht mehr bedienen können. Der Schutz vor Zwangsräumungen und das Recht auf menschenwürdiges Wohnen ist dadurch zu einem wichtigen sozialpolitischen Thema geworden. Die starke Präsenz der Gewerkschaften in Banken und öffentlichen Verwaltungen könnte hier als Potential für eine „Koalition gegenseitiger Unterstützung“ mit diesen Plattformen genutzt werden, um so neue moralische Machtressourcen zu erschließen. 
Auch die Frauenbewegung ist in den Jahren wachsender sozialer Proteste wieder stärker in den Vordergrund getreten und spricht dabei viele Themen der Arbeitswelt an, wie z.B. den Kampf gegen Lohndiskriminierung, die Vereinbarkeit von Beruf und Privatleben und effektivere Gleichstellungsmaßnahmen (Briskin, 2011; Calleja Jiménez, 2016). Angesichts der sowohl personellen als auch inhaltlich deutlich angewachsenen Präsenz der Frauen in den Gewerkschaften liegt hier derzeit das größte Potential für „,nachhaltige Koalitionen“. So haben bspw. die Gewerkschaften gemeinsam mit den Frauenrechtsgruppen für den Internationalen Frauentag am 8. März 2018 zu einem zweistündigen Generalstreik und vielen Protestaktionen im ganzen Land gegen Ungleichheit, prekäre Arbeitsverhältnisse und Gewalt gegen Frauen aufgerufen. Die wachsende Empörung über sexuellen Missbrauch von Frauen und Mädchen und die geschlechtsspezifischen Gewaltakte hat auch die Gewerkschaften erfasst und sensibilisiert. Dieser 8. März wurde zu einem historischen Mobilisierungserfolg; in über 200 Städten gingen insgesamt mehrere Millionen Menschen für effektive Geschlechtergleichheit auf die Straße. Allein in Madrid und Barcelona waren es jeweils mehr als 200.000 .

Eine weitere sozialpolitische Bewegung mit wachsender Unterstützung ist die Forderung nach einem allgemeinen Grundeinkommen. Eine vom gespaltenen und prekären Arbeitsmarkt unabhängige Existenzsicherung hat in Spanien eine große Attraktivität trotz der vielfältigen Probleme einer angemessenen Ausgestaltung und Finanzierung. Einige Gemeinden experimentieren mit diesem Grundsicherungsrecht, und linke Intellektuelle diskutieren und arbeiten in verschiedenen Plattformen zu dem Thema. Eine stärkere Beteiligung der Gewerkschaften an diesen Debatten und die Aufnahme in den gewerkschaftspolitischen Forderungskatalog wäre für beide Seiten eine zusätzliche Machtressource. Für die „Bürgerbewegung für ein garantiertes Grundeinkommen" bedeutet eine gewerkschaftliche Unterstützung zusätzliche Legitimität gegenüber häufig anzutreffender Kritik, dass ein Grundeinkommen die Zentralität sicherer Beschäftigung und öffentlicher Sozialleistungen aushöhlen würde (Raventos, 2016). Für die Gewerkschaften bietet sich die Möglichkeit der Annäherung an die vielen jugendlichen Aktivisten und Aktivistinnen und ein Mitgliedspotential, welches sich derzeit überwiegend an der Protestpartei Podemos orientiert. Die Gesetzesinitiative für eine allgemeine Sozialhilfe für alle Bürger und Bürgerinnen ohne Einkommen, die im Februar 2017 von CCOO und UGT ins Parlament eingebracht wurde, könnte ein erster Schritt zumindest im Sinne einer „Unterstützungskoalition“ sein.

Das Migrations- und Flüchtlingsproblem ist in den letzten Jahren zu einem sozialpolitischen Dauerthema geworden und viele Solidaritätsgruppen engagieren sich in der Aufnahme und Hilfe der aus den Krisengebieten eintreffenden Menschen. Eine verstärkte Zusammenarbeit mit Menschenrechts- und Flüchtlingshilfegruppen im Kampf gegen Rassismus und Ausländerfeindlichkeit liegt daher für Gewerkschaften nahe. Dazu gehört auch der Kampf gegen Ausländerfeindlichkeit in den eigenen Reihen, denn das Argument der Verteidigung der eigenen Arbeitsplätze und des angeblichen Lohndumpings der ausländischen Arbeitskräfte findet auch bei Gewerkschaftsmitgliedern Widerhall. Die jährlichen Berichte der spanischen Sektion von ,SOS Rassismus“ dokumentieren zahlreiche Fälle von Ausbeutung und Diskriminierung ausländischer Arbeitskräfte in überwiegend prekären Arbeitsverhältnissen. Die in den letzten zwei Jahrzehnten stark angewachsene Einwanderungsbevölkerung konnte bislang von den Gewerkschaften nicht organisiert werden. Koalitionen mit 
Hilfsorganisationen für Flüchtlinge und Asylsuchende sind bislang nur selten und allenfalls auf lokaler Ebene anzutreffen.

$\mathrm{Zu}$ guter Letzt steht eine weitere Internationalisierung und Kooperation mit transnationalen Bewegungen für eine sozial gerechtere und ökologisch nachhaltigere Globalisierung auf der gewerkschaftlichen Revitalisierungsagenda (Antenas, 2008). Dies ermöglicht nicht nur den Zugang zu komplementären moralischen Machtressourcen, sondern auch zu neuen effizienten Formen kollektiver Aktion, wie z.B. der Boykott bestimmter Marken oder Kampagnen gegen menschenunwürdige Arbeitsverhältnisse entlang der immer länger werdenden transnationalen Wertschöpfungsketten. Gerade die europäischen Gewerkschaften sind hier zu einer Führungsrolle aufgerufen im Kampf gegen Renationalisierungstendenzen, die in den Krisenjahren in vielen Ländern und Sektoren aufkamen (Beneyto \& Rocha, 2016). Die spanischen Gewerkschaften vertreten eine klare pro-europäische Position und arbeiten aktiv in den europäischen Gewerkschaftsbünden mit. So haben sie bspw. am 14. November 2012, dem europäischen Protesttag des Europäischen Gewerkschaftsbundes, in Spanien zu einem Generalstreik aufgerufen, sind dabei allerdings vor allem von den mittelund nordeuropäischen Kolleginnen und Kollegen alleine gelassen worden.

Seit den Wahlen 2015 und der zugespitzten Krise um die Unabhängigkeitsbestrebungen Kataloniens haben sich zumindest vorübergehend die Kontextbedingungen für eine weitergehende Annäherung zwischen Gewerkschaften und sozialen Bewegungen verschlechtert. Mit dem Einzug der neuen Parteien Podemos und Ciudadanos (Bürgerpartei mit liberaltechnokratischer Orientierung) ist das lange dominante Zwei-Parteien-System einem sehr viel fragmentierteren Mehrparteiensystem ohne klare Mehrheiten gewichen. In Katalonien versuchte eine knappe Parlamentsmehrheit einen verfassungswidrigen einseitigen Abspaltungsprozess vom spanischen Staat voranzutreiben, ein institutioneller Dauerkonflikt, der das gesamte politische Leben in Spanien dominiert und lähmt. Die katalonische Unabhängigkeitsbewegung entwickelte sich in den letzten Jahren zur stärksten sozialen Bewegung der jüngeren Geschichte, mobilisiert Hunderttausende von Menschen in vielen Massenprotesten und hat die katalonische Gesellschaft polarisiert und tief gespalten. Diese Spaltung durchzieht auch die linken Parteien PSOE und Podemos sowie die Gewerkschaften, deren katalonische Landesverbände zu Beginn die Forderung nach einem Unabhängigkeitsreferendum („Das Recht der Katalanen zu entscheiden“) unterstützten, angesichts der verfassungswidrigen einseitigen Unabhängigkeitserklärung diese Unterstützung aber einstellten.

Um die sozialen Bewegungen ist es seither in ganz Spanien nicht nur aufgrund der Dominanz dieses Konflikts in der politischen Öffentlichkeit, sondern auch durch die Tatsache, dass viele Aktivisten und Aktivistinnen nun für Podemos in den Parlamenten und Institutionen arbeiten, sehr ruhig geworden. Der Druck auf die Gewerkschaften zur Erneuerung durch Koalitionen mit sozialen Protestgruppen, der von ihnen in den Jahren 2011-2015 ausging, ist dadurch stark abgeflaut. Auf der anderen Seite suchen die geschwächten Minderheitsregierungen auf allen Ebenen wieder stärker die Gewerkschaften als Verhandlungspartner und zur Unterstützung für politische Vorhaben mit wechselnden, unsicheren Mehrheiten. Dadurch eröffnet sich den Gewerkschaften die Möglichkeit einer Wiedergewinnung verlorener institutioneller Machtressourcen.

Mit dem Einzug der gewerkschaftskritischen Protestpartei Podemos in die Parlamente und dem gleichzeitigen Einbruch der sozialistischen PSOE ist auch das Verhältnis der Ge- 
werkschaften zu den politischen Parteien komplizierter geworden. Insbesondere in den Reihen der CCOO häufen sich Gruppen, die sich für eine Kooperation mit Podemos und damit eine weitere Distanzierung zur sozialistischen Partei aussprechen. Inmitten der politischen Dauerkrise und Fragmentierung und des schwächer gewordenen Erneuerungsdrucks seitens der sozialen Protestbewegungen spricht trotzdem vieles für eine fortschreitende Revitalisierung der Gewerkschaften durch internen Wandel. Der sich zur Zeit vollziehende Generationswechsel in den Gewerkschaftsvorständen, wie er durch den neuen CCOO-Generalsekretär Unai Sordo repräsentiert wird, könnte sich dabei positiv auf ein offeneres und jüngeres Profil der Arbeitnehmerorganisationen auswirken. Der Rückzug der Führungspersonen, die seit der Demokratisierung die spanischen Gewerkschaften geprägt und vertreten haben, ist auf der einen Seite ein Verlust an Erfahrung und gelebtem Kompromiss, birgt jedoch auf der anderen Seite Chancen für eine forcierte Verjüngung und Erneuerung.

\section{Ausblick}

Walther Müller-Jentsch (1994, S. 643) nannte die Arbeitskraft „die Brücke zwischen Produktionssystem und Zivilgesellschaft" und die Gewerkschaften daher die zentrale vermittelnde Instanz zur Verknüpfung von politischen und wirtschaftlichen Bürgerinteressen. Diese intermediäre Rolle gilt es in Spanien zurückzuerobern in einer Zeit, in der soziale und politische Bürgerrechte hart umkämpft sind, während die industriellen Bürgerrechte unter heftigen Beschuss geraten sind. Das vergangene Jahrzehnt einer lang anhaltenden wirtschaftlichen Rezession brachte für die spanischen Gewerkschaften einen Rückgang der Mitgliederzahlen, des politischen Einflusses und des gesellschaftlichen Rückhalts, während gleichzeitig neue Protestbewegungen zum Sprachrohr der sozialen Unruhen und politischen Forderungen wurden. Diese neuen Protestgruppen und Organisationsformen sind auf der einen Seite sehr instabil und heterogen, beweisen aber auf der anderen Seite die Fähigkeit, den aktuellen politischen Unmut gegenüber der sozial verwerflichen Krisenpolitik und der korrupten politischen Klasse zu kanalisieren; eine Fähigkeit, die den traditionellen linken Parteien und Gewerkschaften weitgehend abhanden gekommen ist. Für die Gewerkschaften bedeuten diese Bewegungen daher gleichzeitig eine Bedrohung in ihrer Monopolstellung als „manager of discontent“ (Wright Mills, 1948, S. 9), gleichzeitig aber auch eine Revitalisierungschance bei der Suche nach einer strategischen Erneuerung. Koalitionen und Kooperationen mit den neuen sozialen Bewegungen bergen zahlreiche Potentiale zur Erschließung neuer (alter) gewerkschaftlicher Machtressourcen auf dem Weg zurück in die Gesellschaft. Die starke katalonische Unabhängigkeitsbewegung, die das politische Leben in Spanien seit 2015 weitgehend paralysierte, zeigt allerdings die zunehmende Fragmentierung und Spaltung der spanischen Gesellschaft; eine Fragmentierung, die sowohl durch die Gewerkschaften als auch durch die sozialen Bewegungen geht und nachhaltige Koalitionen und Erneuerungsstrategien zusätzlich erschwert.

Für lange Zeit institutionell eingebundene und abgesicherte Organisationen bedeutet eine strategische Wende zu einer sozialen Bewegungsgewerkschaft zahlreiche Risiken und organisationsinterne Barrieren. Nur starke Impulse von der Basis bei gleichzeitigem Wandel in den Gewerkschaftsführungen versprechen Revitalisierungserfolge in Zeiten widriger 
wirtschaftlicher und politischer Rahmenbedingungen (Voss, 2010). Bislang haben die groBen spanischen Gewerkschaften eher defensiv auf die neuen Herausforderungen und Machtverluste reagiert, ihre Diskurse weitgehend beibehalten und lediglich Fusionen der Industrieverbände zu wenigen großen Einzelgewerkschaften vorangetrieben. Die traditionelle institutionelle Machtbasis bleibt dabei formell erhalten, insofern weiter Tarifverhandlungen und bilaterale Vereinbarungen durchgeführt werden ${ }^{6}$. Diese Institutionen verlieren jedoch aus gewerkschaftlicher Sicht ihre Gestaltungskraft und drohen, zu hohlen „Zombie-Institutionen“ zu verkommen. Arbeitgeber- wie Arbeitnehmerverbände legitimieren sich dabei über Vereinbarungen zu wenig konfliktträchtigen Themen (Aus- und Weiterbildung, Vereinbarkeit von Beruf und Familie, Gesundheitsschutz) und verbreiten gemeinsame politische Erklärungen (öffentliche Investitionen, Wirtschaftsförderung, sozialer Dia$\log$ ), während sich viele Unternehmen die neuen Arbeitsgesetze zunutze machen, um einseitig aus den Branchentarifverträgen auszusteigen. Charakter und Ziele der neuen bzw. erstarkten sozialen Protestbewegungen gegen die sozialen Verwerfungen des neoliberalen Krisenmanagements und die korrupte politische Klasse bieten unserer Analyse zufolge vielfältige Anknüpfungspunkte für nachhaltige Koalitionen mit den Gewerkschaften bei Machtgewinn auf beiden Seiten. Insbesondere der Zugang zu neuen jüngeren, weiblicheren und multikulturelleren Mitgliedsgruppen birgt für die spanischen Gewerkschaften ein hoch attraktives Aktionsfeld. Neben neuen komplementären Machtressourcen würden dabei auch traditionelle Positionen in Tarifverhandlungen und politischen Konzertierungskartellen gestärkt. Bislang allerdings agieren die spanischen Arbeitnehmerorganisationen noch überwiegend zögerlich im Warten auf bessere Verteilungsbedingungen in einer unterstellten wirtschaftlichen Erholung. „Die spanischen Gewerkschaften bieten das Bild eines Kapitäns, der sich weigert, das sinkende Schiff mit dem Namen „Konzertierung“ zu verlassen“ (Gago, 2013, S. 1100).

\section{Literatur}

Antenas, J. (2008). Los sindicatos ante la globalización. ¿Hacia qué nuevas formas de solidaridad internacional? Cuadernos de Relaciones Laborales, 26 (1), 35-55.

Antón, A. (2007). Jóvenes trabajadores y sindicalismo en España. Análisis de un desencuentro (Doktorarbeit). Madrid: Universidad Complutense de Madrid.

Avdagic, S., Rhodes, M. \& Visser, J. (2005). The emergence and evolution of social pacts: A provisional framework for comparative analysis. N-05-01. Brussels: Eurogov.

Bauman, Z. (2003). Flüchtige Moderne, Frankfurt am Main: Suhrkamp.

Beneyto, P. \& Rocha, F. (2013). Acción sindical y relaciones laborales transnacionales. Congreso de la Federación Española de Sociología. Madrid, 10-12 julio.

Bernaciak, M., Gumbrell-McCormick, R. \& Hyman, R. (2014). European trade unionism: from crisis to renewal? Brussels: European Trade Union Institute.

Brinkmann, U., Choi, H.-L., Detje, R., Dörre, K., Holst, H., Karakayali, S. \& Schmalstieg, C. (2008). Strategic Unionism: Aus der Krise zur Erneuerung der Gewerkschaften?. Wiesbaden: VS Verlag für Sozialwissenschaften.

6 Immerhin gelang es den Gewerkschaften durch einen erneuerten Rahmentarifvertrag 2015 (III Acuerdo para el Empleo y la Negociación Coleciva AENC) mit dem Arbeitgeberverband, den Trend zu abnehmender Tarifdeckung zu stoppen und die Tarifverhandlungen wiederzubeleben (CES, 2016; 2017). 
Briskin, L. (2011). Union Renewal, Postheroic Leadership, and Women's Organizing. Crossing Discourses, Reframing Debates. Labor Studies Journal, 36 (4), 508-537. doi: $10.1177 / 0160449 X 11422608$

Byford, I. (2009). A Comparative Study of Trade Union Renewal Strategies: Partnership, Organising and Social Unionism (Doktorarbeit). Bristol: University of the West of England.

Calleja, J.P. (2016). Estrategias de revitalización de los sindicatos españoles. (Doktorarbeit). Valencia: Universidad de Valencia.

Castells, M. (2012). Redes de indignación y esperanza. Madrid: Alianza.

CES (Consejo Económico y Social) (2016). Memoria sobre la Situación Socioeconómica y Laboral. Madrid: CES.

CES (Consejo Económico y Social) (2017). Revista Cauces 36 (Cuadernos del Consejo Económico y Social).

CIS (2015). Barómetro de abril de 2015 del Centro de Investigaciones Sociológicas. Estudio no 3082. Madrid: CIS.

Diani, M. (2015). Revisando el concepto de movimiento social. Encrucijadas. Revista crítica de ciencias sociales, 9, 1-16.

Flanders, A. (1970). Management and Unions. London: Faber \& Faber.

Frege, C., Heery, E. \& Turner, L. (2004). Union Strategies in Comparative Context. In C. Frege \& J. Kelly (Hrsg.), Varieties of Unionism. Strategies for Union Revitalization in a Globalizing Economy. Oxford: Oxford University Press. doi: 10.1093/acprof:oso/9780199270149.001.0001, doi: 10.1093/acprof:oso/9780199270149.003.0003

Gago, A. (2013). Los sindicatos mayoritarios CCOO y UGT ante la crisis económica: ¿Declive o revitalización? Anuario del Conflicto Social 2012, 1075-1104.

Gallas, A. \& Nowak, J. (2012). Agieren aus der Defensive. Ein Überblick zu politischen Streiks in Europa mit Fallstudien zu Frankreich und Großbritannien. In: A. Gallas, J. Nowak \& F. Wilde (Hrsg.). Politische Streiks im Europa der Krise. Hamburg: VSA.

Gil, M.A. (2016). Mareas, movimientos sociales y sindicalismo. Madrid: Fundación $1^{\circ}$ de mayo CCOO.

Gumbrell-McCormick, R. \& Hyman, R. (2013). Trade Unions in Western Europe. Hard Times, Hard Choices. Oxford: Oxford University Press. doi: 10.1093/acprof:oso/9780199644414.001.0001

Hälker, J. \& Vellay, C. (Hrsg.) (2007). Union renewal-Gewerkschaften in Veränderung. Düsseldorf: Hans Böckler Stiftung.

Hassel, A. (2012). What are unions for? The changing role of trade unions in modern economies. Madrid: Fundación Alternativas, Doc. 2012/06.

Huke, N. \& Tietje, O. (2014a). Zwischen Kooperation und Konfrontation. Machtressourcen und Strategien der spanischen Gewerkschaften CCOO und UGT in der Eurokrise. Industrielle Beziehungen, 21 (4), 371-389.

Huke, N. \& Tietje, O. (2014b). Gewerkschaftliche Erneuerung in der Eurokrise. Neue Organisationsformen der spanischen Gewerkschaften während des Protestzyklus ab 2011. PROKLA, 44 (4), $531-548$.

Huke, N. (2017). „Sie repräsentieren uns nicht“. Soziale Bewegungen und Krisen der Demokratie in Spanien. Münster: Westfälisches Dampfboot.

Kloosterboer, D. (2007). Innovative Trade Union Strategies. Amsterdam: Stichting FNV Pers.

Köhler, H.-D. \& González Begega, S. (2016). Tenneco-Gijón. A case of local worker resistance against a global player. In V. Pulignano, H.-D. Köhler \& P. Stewart (Hrsg.). Employee and employer relations in an era of change. Challenges and responses from a multi-level perspective in Europe (S. 17-36). Brussels: ETUI. 
Köhler, H.-D. (1993). Spaniens Gewerkschaftsbewegung. Demokratischer Übergang, Regionalismus, ökonomische Modernisierung. Münster: Westfälisches Dampfboot.

Köhler, H-D. \& Calleja, J.P (2017). Spain: A peripheral economy and a vulnerable trade union movement. In Lehndorff, S., Dribbusch, H. \& Schulten, T. (Hrsg.). Rough Waters: European trade unions in a time of crises. Brussels: ETUI.

Laraña, E., Johnston, H. \& Gusfield, J. R. (1994). New Social Movements. Philadelphia: Temple University Press.

Lehndorff, S., Dribbusch, H. \& Schulten, T. (Hrsg.) (2017). Rough waters. European trade unions in a time of crisis. Brussels: ETUI.

López Calle, P. (2007). La desmovilización general: jóvenes, sindicatos y reorganización productiva. Madrid: Catarata.

Martín Valverde, A. (1991). European Employment \& Industrial Relations Glossary: Spain. London/Luxembourg: Eurofound. doi: 10.1111/j.1468-2338.1991.tb00637.x

Müller-Jentsch, W. (1994). Über Produktivkräfte und Bürgerrechte. In N. Beckenbach \& W. van Treeck (Hrsg.), Umbrüche gesellschaftlicher Arbeit, Soziale Welt SB 9, 643-661.

Offe, C. \& Wiesenthal, H. (1980). Two logics of collective action: Theoretical notes on social class and organizational form. In: Political Power and Social Theory, 1, 67-115.

Offe, C. (1985). New Social Movements: Challenging the Boundaries of Institutional Politics. Social Research, 52 (4), 317-868.

Oñederra, U. (2016). Coop57: una herramienta complementaria a la lucha sindical. II Encuentro de profesionales del asesoramiento laboral y social UPV/EHU: "Negociación colectiva y control sindical. Aspectos laborales y económicos ". Leioa, 29-30 septiembre 2016.

Raventos, D. (2016). Los sindicatos y la renta básica. Sin Permiso, 18.12.2016.

Rigby, M. \& García Calavia, M.A. (2017). Institutional resources as a source of trade union power in Southern Europe. European Journal of Industrial Relations. doi: 10.1177/0959680117708369

Rojo Torrecilla, E. (1990). Las tareas pendientes. Política y Sociedad, 5, 31-44.

Schmalz, S. \& Dörre, K. (2014). Der Machtressourcenansatz: Ein Instrument zur Analyse gewerkschaftlichen Handlungsvermögens. Industrielle Beziehungen, 21 (3), 217-237.

Streeck, W. (2009). Re-forming Capitalism: Institutional Change in the German Political Economy. Oxford: Oxford University Press.

Tarrow, S. (2004). El poder en movimiento. Los movimientos sociales, la acción colectiva y la política. Madrid: Alianza.

Tattersall, A. (2005). There is Power in Coalition: A framework for assessing how and when unioncommunity coalitions are effective and enhance union power. Labour and Industry, 16 (2), 97 112. doi: 10.1080/10301763.2005.10669325

Tattersall, A. (2011). The Power of Union-Community Coalitions. Renewal, 19 (1), 75-82.

Touraine, A. (1981). The voice and the eye. An analysis of social movements. Cambridge: Cambridge University Press.

Turner, L. (2005). From transformation to revitalization: A new research agenda for a contested global economy. Journal of Industrial Relations, 32 (4), 383-399.

doi: $10.1177 / 0730888405279071$

Urban, H-J. (2012). Crisis corporatism and Trade Union Revitalisation in Europe. In S. Lehndorff (Hrsg.), A triumph of failed ideas: European models of capitalism in the crisis (S. 219-241). Brussels: ETUI.

Waterman, P. (1993). Social-Movement Unionism: A new Union Model for a New World Order. Fernand Braudel Center Review, 16 (3), 245-278.

Webb, S. \& Webb, B. ([1894] 1990). Historia del Sindicalismo 1666-1920. Madrid: Ministerio de Trabajo y Seguridad Social. 
Wright Mills, C. (1948). The new men of power: America's labor leaders. New York: Harcourt Brace.

Zald, M. N., \& McCarthy, J.D. (1980). Social Movement Industries: Competition and Cooperation among Movement Organizations. In: L. Kriesberg (Hrsg.), Research in Social Movements, Conflict and Change (S. 1-20). Greenwich: JAI Press. 


\title{
Talking about the same but different? Understanding social movement and trade union cooperation through social movement and industrial relations theories"
}

\begin{abstract}
In the context of continuing political, social, and economic crises, trade unions in most European countries are seen as weakened, protest as having little influence, and the solidarity between European populations as damaged. Under these circumstances, scientists and practitioners have placed hope in the cooperation of social movements and trade unions in order to revitalise trade unions and achieve common goals. However, the conditions for forming alliances between trade unions and social movement organisations have, thus far, been primarily researched, and partially theorised, from the point of view of different disciplines. In doing so, approaches that emphasise the strategic alignment with resources and context diverge from approaches that highlight the relevance and necessity of shared ideologies or identities. This contribution aims to bring existing approaches from movement and industrial relations research into dialogue with each other and calls for a further integration of both perspectives. It contributes to a more holistic understanding of joint movement and trade union action current concepts such as social movement unionism cannot provide. It uses two examples to show that instrumental, strategy-driven modes and identity-based, culturally-driven modes of cooperation are not contradictory. There are situations in which strategic decisions on resources and political influence are more decisive than ideological proximity and vice versa. These findings are of social and scientific relevance for understanding mechanisms of solidarity construction and processes of bridging differences even in increasingly fragmented and unequal societies.
\end{abstract}

Keywords: Social movements, trade unions, cooperation, cross-organisational cooperation, transnational cooperation (JEL: J51, J59, Z13)

* Sabrina Zajak, Giulia Gortanutti, Johanna Lauber, Ana-Maria Nikolas, Ruhr-Universität Bochum, Institut für soziale Bewegungen, Clemensstr. 17-19; 44789 Bochum; corresponding author: sabrina.zajak@ rub.de We are grateful for the very constructive and helpful feedback from Marissa Brookes and Britta Rehder, the participants at the cross-movement mobilization conference in Bochum, where we discussed the paper, and the constructive feedback of the anonymous reviewers. We also thank the Hans-Böckler Foundation, who provided funding for a research project on cooperation between social movements and trade unions (http://www.isb.ruhr-uni-bochum.de/forschung/graduiertenkollegs/transnationale-allianzen/index.html.de), that this paper is based on.

** Artikel eingegangen: 31.08.2017, revidierte Fassung akzeptiert nach doppelt-blindem Begutachtungsverfahren: 8.3.2018 


\section{Sprechen wir über das selbe, nur anders? \\ Wie Bewegungs- und Industrielle-Beziehungs-Forschung \\ Kooperationen zwischen sozialen Bewegungen und Gewerkschaften erklären.}

\section{Zusammenfassung}

Im Kontext anhaltender politischer, sozialer und ökonomischer Krisen gelten Gewerkschaften in den meisten europäischen Ländern als geschwächt, Protest als wenig einflussreich und der Zusammenhalt zwischen europäischen Bevölkerungen als beschädigt. Um Gewerkschaften zu revitalisieren und gemeinsame Ziele zu erreichen, wird von Wissenschaft und Praxis Hoffnung in die Kooperation von sozialen Bewegungen und Gewerkschaften gesetzt. Allerdings wurden die Entstehungsbedingungen von Allianzen zwischen Gewerkschaften und sozialen Bewegungsorganisationen bisher nur aus der Sicht der jeweiligen Disziplin erforscht und theoretisiert. Dabei stehen sich Ansätze gegenüber, die entweder strategische Ausrichtung auf Ressourcen und Kontext betonen oder die Relevanz und Notwendigkeit geteilter Ideologien oder Identitäten hervorheben. Dieser Artikel bringt Bewegungs- und industrielle Beziehungsforschung miteinander in Dialog und fordert eine Integration beider Ansätze. Er leistet damit einen Beitrag zu einem holistischeren Verständnis von gemeinsamem Bewegungs- und Gewerkschaftshandeln, was von bisherigen Konzepten wie dem „social movement unionism“ nicht geleistet wird. An zwei Beispielen zeigt der Beitrag, dass instrumentelle, strategie-zentrierte und kulturbezogene, identitätsbasierte Kooperation keine Gegensätze sind. Es gibt jedoch Situationen, in denen strategische Entscheidungen über Ressourcen und politischen Einfluss entscheidender sind als ideologische Nähe und vice versa. Erkenntnisse über Mechanismen der Solidarisierung und Überbrückung von Unterschieden sind gerade in zunehmend fragmentierten Gesellschaften von wissenschaftlicher und gesellschaftlicher Bedeutung.

Schlagwörter: Soziale Bewegungen und Gewerkschaften, Kooperation, gewerkschaftliche Revitalisierung, kollektive Identität, Austeritätspolitik, Handelspolitik

\section{Talking about the same, but different?}

Why do trade unions and social movement organisations work together? Social movement organisations and trade unions have organised joint protest events, shared campaigns, or worked together using a variety of strategies of political influence. These often have been labelled social movement unionism (Ford, 2009; Mathers, Upchurch \& Taylor, 2019; Nowack 2017; Zajak, Piper \& Egels-Zanden, 2017). Still, there have also been occasions where they have competed with each other; organising separate events (e.g. the May 1st trade union demonstrations or alternative social movement demonstrations) or reaching out to the same target group (e.g. precarious workers or the unemployed) (Choi \& Mattoni, 2010). For the most part, however, they ignore each other. They operate in different spheres (the industrial sphere versus the public sphere) and usually have neither incentive nor necessity to work together. They differ in their organisational structure (bureaucratic and hierarchical versus networks based on informal and decentralised participation), underlying democratic principles (representative democracy versus undertakings in direct democracy), 
or motives of collective action (material and employment related concerns versus postmaterialist values) (Grote \& Wagemann, 2019). Indeed, both social movement and industrial relations literature have stressed that trade unions and social movements represent distinct organisational forms. It is against this background that social movement and industrial relations theory developed rather independently and have followed "their own avenues" (Grote \& Wagemann, 2019, preface), despite having shared roots in Marxist thinking (Yon, 2016).

Industrial relations scholars take the inherent conflicts of interest between employers and employees as a basic starting point for their analyses. They study the diverse institutional arrangements that shape the employment relationship, ranging from norms and power structures on the shop floor to collective bargaining arrangements at different levels (Dunlop, 1993 [1958]; Jackson, Kuruvilla, \& Frege, 2013; Pries, 2010; Müller-Jentsch, 1995). Social movement scholars, on the other hand, explicitly distance themselves from explanations grounded in class relations as a sufficient condition for mobilisation and protest, arguing that factors such as resource mobilisation, political opportunities, framing, and identities are paramount (Della Porta \& Diani 2010; Rucht, 2017; McAdam, McCarthy, \& Zald, 1996). Touraine (1984) linked the decline in prominence of Marxist theories to the emergence of new post-industrial social movements in Europe and to the fact that trade unions had, to a great extent, been incorporated in the (neo-) corporatist structures of the state. This led to a decreasing interest in trade unions in social movement theories. Despite this, empirical studies began to explore the relationship between social movements and trade unions, but they did so from the perspective of either social movement studies or industrial relations (IR), or to be more precise from the field of labour studies within IR. ${ }^{1}$

For social movement scholars, the temporary neglect of trade unions changed when researchers re-discovered and re-included capitalism in their analysis (della Porta, 2015; Barker, Cox, Krinsky, \& Nilsen, 2013). Especially in the context of the European economic crisis, studies began to re-consider trade unions as relevant actors (Kanellopoulos, Kostopoulos, Papanikolopoulos, \& Rongas, 2017; della Porta et al., 2012). ${ }^{2}$ Social movement scholars started looking into the development of cooperation across organisational differences from the cultural perspective, which has become dominant in social movement theories, focussing on processes of brokerage, bridge building and the construction of a joint identity (Baumgarten, 2014; Flesher Fominaya, 2010)

Among industrial relations scholars, the interest in social movement-trade union cooperation developed in the context of the trade union revitalisation debate (Schmalz \& Dörre, 2013; Rehder, 2008; Frege \& Kelly, 2003). Taking into account the decline of unionisation and collective bargaining, social movements have increasingly been considered as strategic partners who could compensate for the loss of structural, associational and institutional

1 A lot of work on trade unions has been done in the "sociology of work", "industrial sociology", "political economy" and "labour history", which could also add valuable perspectives, concepts, and empirical evidence, especially concerning cultural aspects. However, this is beyond the scope of this paper (for example Bieler et al. 2015; Gallas 2015; Jansen 2013).

2 Yon speaks of a "long-awaited homecoming" of the labour movement in social movement studies (Yon, 2016, p.82). Empirically, trade unions have (historically) always been part of social movements. For example, in a longitudinal study of protest events in Germany, Rucht showed a significant amount of trade union participation (2007). 
power of trade unions (Tattersall, 2010; Fletcher \& Gapasin, 2008; Turner, 2006; Frege \& Kelly, 2004). A concept, which should capture this dynamic, is social movement unionism. The term was introduced to capture social movement and trade union cooperation with the overall aim of democratizing all social relations (Waterman, 1991). ${ }^{3}$ Thus, in contrast to cultural approaches, which are key in social movement studies and stress the importance of shared identities and worldviews, this perspective predominantly focused on strategic considerations in order to gain additional modes of political and economic influence (Schmalz \& Dörre, 2013; Webster, 2015; Brookes, 2013).

In sum, to answer our question on why trade unions and social movements cooperate, the literatures on industrial relations and social movements provide two explanations: one perspective stresses the strategic considerations on how to increase power, influence and resources; the other perspective emphasises the relevance of shared world views, common identities and other cultural similarities. What we do not know is how these factors relate to each other. Which combination is more likely to result in the initialisation or disintegration of cooperation? By cooperation we mean working together, for example organising a campaign or protest event on more than one occasion. We use the word cooperation or alliance instead of collective action to indicate: firstly that we are looking at organisations not individuals; secondly, that the actors still keep some autonomy and distinctiveness - they do not merge into a single entity (see Rucht, 2004, p. 203); and thirdly, avoidance of the normative bias inherent in concepts such as social movement unionism or networks of labour activism (Zajak et al., 2017). The contribution of this paper is two-fold: first this article follows Grote \& Wagemann's (2019) call “to take a position of analytical equidistance with respect to both forms of collective action". By looking at how cooperation is conceptualised within social movement studies and IR theories, we show that both research fields do consider similar factors when explaining cooperation between collective actors - the politicaleconomic context, resources and culture - albeit in different ways. By including factors from both research fields, we contribute to the development of a more holistic model of cooperation between these collective actors. Second, based on the combination of these three explanatory dimensions, we identify and differentiate between various pathways that lead to cooperation. We choose two examples that contrast one case where shared roots and understandings made cooperation possible, despite limited strategic chances to reach certain goals or increase organisational resources (the Alter Summit network), with another case where movement organisations and trade unions cooperated in spite of significant ideological differences (Anti TTIP network). Our results suggest taking a closer look at the pathways and drivers that lead to cooperation or its break-up. Next, we give an overview of the key theoretical concepts from both research fields - social movement studies and IR - before presenting our two examples.

3 The term has been used widely and across a broad range of countries (see also Köhler et al.'s and Fink's contribution in this volume). However, the concept is based on a normative view, claiming that cooperation with social movements is necessary for trade unions not only to revitalize but also to become more democratic and less hierarchic (Waterman 1991, Nowak 2017). The concept has little value for explaining why cooperation empirically emerges in some contexts but not in others and why sometimes cooperation is sustained while in other times it dissolves. 


\section{Paths to cooperation between trade unions and social movements}

Both social movement and industrial relations research use similar dimensions to explain collective action, but give differing names to specific theories or analytical concepts. In social movement studies, resource mobilisation theory, political process theory, collective identity, and framing concepts have been most influential in the study of collective action (Rucht \& Roth, 2007; Hellmann \& Koopmans, 1998). In labour studies, the resource dimension has been dealt with in the power resource approach, context is considered in the political-economic perspective, and cultural aspects play a role in concepts of ideology and class consciousness (Bieler et al., 2015; Gumbrell-McCormick \& Hyman, 2013). Table 1 summarises the main dimensions.

Table 1:Explanatory dimension of cooperation

\begin{tabular}{lll}
\hline Explanatory dimensions & Social movement theory & Industrial relations \\
\hline Context & - Political opportunity structure & - Political-economic context \\
\hline Resources & - Resource mobilization & - Power resources \\
\hline Culture & - Framing & - Ideologies \\
& - Collective identity & - Class-consciousness \\
\hline
\end{tabular}

Source: own compilation

The question, then, is which combination of factors best explains cooperation. Movement research long ago stressed that looking at only one theoretical paradigm (political opportunities, resources or framing/identities) is not enough to understand mobilisation or collective action (McAdam et al., 1996). This can also be said for trade union actions. In the following section, we cross-fertilize both disciplines and point out various indicators in all three dimensions, which will help us to understand joint actions involving social movements and trade unions.

\section{Dimension I: Context}

Social movement and IR scholars have both stressed the crucial importance of institutions for explaining the strategies and strength of movements and trade unions (Tarrow, 1996; Müller-Jentsch, 1995). In social movement studies, the most prominent approach to conceptualise how context affects the development and outcome of social movement is political process theory, with its key concept of political opportunity structure (POS). Activists do not choose their goals at random. The frequency and intensity of protest actions depends to a large extent on the openness of the political system (Meyer, 2004). "Political opportunities are understood as signals that encourage or discourage actors to form social movements" (Tarrow, 1996, p. 54). Political pluralism, divisions of elites, institutional access, or decline in repression all count as favourable opportunities (Meyer \& Minkoff, 
2004). ${ }^{4}$ The presence of potential allies has also been treated as an opportunity dimension, as finding allies is "critical for a movement's survival, particularly when it is in an outsider position" (Rucht, 2004, p. 197). From POS theory we can derive two broader aspects that define incentives for social movement-trade union cooperation.

Firstly, one basic premise of the POS approach is that the political context shapes the grievances around which movements organise, thereby shaping social movements. Groups tend to cooperate with each other and formulate joint tactics, goals, and claims based on those shared grievances (Goldstone \& Tilly, 2001). Grievances can emerge as a response to the immediate political environment, but they can also be more deeply rooted in societal cleavage structures (Kriesi, 2004). Going back to Lipset \& Stein (1967), social cleavage theory argues that political action is deeply rooted in key conflicts within society. Key divides include class conflict, religious divides, core and periphery cleavages, and, as more recently stated, cosmopolitan or transnational cleavage (Hooghe \& Marks, 2018; Eggert \& Giugni, 2015). Kriesi et al. (2012) argued that the more prominent the class cleavage in society would grow, the narrower the space for cultural protest, associated with so called "new social movements", would be. In terms of cooperation between trade unions and social movements, the cleavage argument suggests that the strong relevance of class cleavage would weaken so called "new social movements" and make them less appealing as cooperation partners for trade unions. This strongly resonates with research in IR, which found that strong unions are less likely to cooperate with social movements. GumbrellMcCormick \& Hyman (2013) found that the decline of traditional participatory power influences trade unions to search and use alternative power resources through coalition building. In countries with stronger and more coordinated institutions, cooperation with business and with state agencies is considered a core strategy and, thus, strategizing with social movement organisations may be less necessary (Frege et al., 2004).

Still, this assumption could also be challenged. As della Porta et. al. (2017) state, the austerity crisis in Europe has transformed the cleavage structure in affected countries by enhancing the precarisation of labour and a proletarisation of the middle class. A strengthening of the class cleavage, however, would imply a weakened interest from trade unions in cooperating with "new social movements". Nevertheless, the fact that European societies are under severe social stress also means that many different groups are affected and can become mobilizing actors and therefore potential cooperation partners. Being exposed to similar threats of economic depression, austerity policies, and arcane, high-speed political decision-making might create a particularly fertile ground for alliance formation (Roose, Sommer, \& Scholl, 2018; Zajak, 2018). With this in mind, Alter Summit is an interesting example of a European wide coalition of trade unions and social movement organisations in response to the European crisis. We show below that these contradictory aspects are not mutually exclusive, but represent two tendencies that organisations are exposed to in the aftermath of the economic crisis in Europe: on the one hand, fragmentation due to the national search solutions, and, on the other hand, the welding of organisations through a new European cleavage structure.

4 The term structure has been largely abandoned in political opportunity research, as most scholars have agreed that opportunities have to be perceived, interpreted, and framed, and depend on the specific historic context and situation (Gamson and Mayer, 1996, p.283). 
Secondly, the availability of institutionalised access of one organisation can increase the interest of others in cooperating with that organisation. We can assume that activist organisations that wish to increase their influence through improved institutional access will develop an interest in joining forces with trade unions. Insider organisations might also be able to strengthen their position by participating in a broader network, for example during consultation procedures with DG Trade in the European Union (Fogarty, 2013). This assumption is challenged by the perspectives of IR scholars who study the participation of trade unions and co-determination in diverse institutional arrangements (Berger et al., 2018; Pries, 2010:). Trade unions that have institutionalised sources of influence (e.g. Germany or Nordic countries) (Bernaciak, Gumbrell-McCormick, \& Hyman, 2014) are expected to be less likely to cooperate. Trade unions that are not well integrated in corporatist structures, countries like Greece, Spain and Portugal, are more open to cooperating with social movements.

Overall, using the industrial and political context as explanatory context suggests that different organisational forms might work together due to strategic considerations, even if they do not share the same specific goals, identities, or frames. Closely linked to theories dealing with context are approaches that take the relevance of resources into consideration. Resource mobilization theory (RMT) in social movement studies and the power resource approach (PRA) in labour studies both share the perspective of strategic choice with context theories. ${ }^{5}$

\section{Dimension 2: Resources}

According to resource mobilization theory (RMT), a group with a minimum of resources must start the mobilisation process and reach out to attract more resources from others (Jenkins, 1983; Polanska \& Piotrowski, 2015). Social movement resource mobilisation theorists remain relatively vague when it comes to specifying resources. Tilly (1978, p. 10), for example, lists:

"labour, power, goods, weapons, votes and any number of other things, just so long as they are usable in acting on shared interests".

Predefining resources is difficult because resources can vary across contexts and depend on the goals that the collective actors strive to achieve and the tactics and strategies they adopt (Etzioni, 1968). Despite the variety of potential resources, it is of course possible that organisations strive to gain the same resources. In cases in which these organisations have different interests, it is likely that they will be in a competitive relation and cooperation will not occur between them. A helpful differentiation was made by Rogers (1974) and Jenkins (1983), who suggested differentiating between types of resources by asking whether they enable the exertion of power or whether they serve the mobilisation process itself. Overall, social movement research has been more interested in resources that serve the mobilisation process than with power resources (in contrast to the approaches in IR). From this point of

5 Resource mobilization theory has also inspired the development of the power resource approach e.g. in Kelly's work (1997, 1998), also Darlington (2012). 
view, organisations as such are considered a key resource, because they contribute to the emergence, growth, and maintenance of movements over time by providing infrastructure for communication between the different components that form a movement, as well as facilitating communication with organisations from other movements or with institutions and individuals (Kendall, 2005). This perspective suggests that cooperation is more likely to occur between organisations that share similar organisational characteristics in terms of income, number of paid staff and internal committees, chapters, and number of members (Andrews, Edwards, Al-Turk \& Hunter, 2016). ${ }^{6}$ Following these insights, we assume that the more similar the movement and trade union organisations are, the more likely it is that cooperation will occur. In other words, social movements which have developed, or integrated institutionalised social movement organisations are more likely to work with trade unions than movements that do not have this type of organisation in their constituency. The latter often relies on more disruptive power resources (cf. McCarthy \& Walker, 2010; Caniglia \& Carmin, 2010). Similarly, unions that employ disruptive strategies have a decentralised structure, have limited organisational characteristics, and depend directly on their ability to mobilise (e.g. anarchist unions), could be more prone to cooperate with movements that prioritise the same resources.

As movement scholars tend to be vague about the type and nature of resources, we suggest adding the power resource approach developed within union revitalisation studies, as it is more specific. This strand of research tried to identify new power resources that could help to revitalise trade unions. Despite some variation between different approaches, structural, associational, institutional, coalitional, and discursive/symbolic power resources count as the main pillars of the power resource approach (Brookes, 2013; Schmalz \& Dörre, 2014; Webster, 2015; Zajak, 2017). The basic assumption emerging from this perspective is that trade unions seek alliances with social movements when they lose associational power (the ability to organise workers and to mobilise them to take collective action) (Silver, 2003; Wright, 2000), structural power (the ability to disrupt), or institutional power (exerting leverage through social partnership institutions) (AK Strategic Unionism, 2013). The assumption is that unions that lose members and the ability to disrupt production or that experience a decrease of their institutional access will cooperate with social movements under two conditions: movement organisations either have the ability to leverage institutions (Brookes, 2013) or the ability to win over the public and thus possess symbolic power, through their ability to influence what is publicly perceived as right or wrong (McGuire, 2013; Chun, 2009; Webster, Lambert, \& Bezuidenhout, 2008). However, not all trade unions view symbolic power as a necessary or relevant resource, and thus do not perceive cooperation with social movements to be a good strategic choice. As Ibsen \& Tapia (2017) have shown, many unions have responded to the collapse of collective bargaining and membership decline through a strategic re-orientation, organising new members and mobilising the existing members, thereby shifting focus from institutionalised power resources to trade unions' original associational power source (Urban, 2010; Frege, 2004). It is therefore possible that unions that strongly emphasise membership will only cooperate with movement organisations if they expect new membership through activism. Unions will

6 In social network analysis, it is called homophily principle when similar organisations or individuals work together (McPherson et al., 2001). 
not cooperate with movement organisations if they consider the organisation unable to leverage symbolic power (i.e. because they consider the organisation or their action repertoires as illegitimate).

Overall, PRA has been developed to explain cooperation from the trade union perspective but does not really consider which resources the potential cooperation partner, that is not a trade union, needs. It is possible that organisations, even in a favourable political context and in the presence of opportunities to increase influence through cooperation, might not cooperate because of a different assessment of what would count as an appropriate resource. Similarly, unfavourable opportunity structures could be ignored or altered when the alliance structure is able to acquire sufficient resources to overcome obstacles in the political-economic context. Still, what is viewed as a power resource (or not) is a matter of shared frames and ideology - in other words we need to include the cultural dimension to understand cooperation.

\section{Dimension 3: Culture and shared identities}

The last dimension refers to cultural factors like frames, shared identities, classconsciousness, and ideologies as key factors in explaining collective action. The hypothesis resulting from this perspective is straightforward: alliance formation can hardly be understood "without reference to cultural processes of identity formation and group solidarity" (Buechler, 1993, p. 230). The aspect of cultural influence is reflected in both social movement and industrial relation research, but with different intensities regarding theoretical relevance and empirical application and preferring different concepts and approaches. Obviously, there is no such thing as "the one" cultural approach, just like there are many definitions of culture (for a recent overview in social movement studies see Baumgarten et al., 2014). While some cultural approaches define any strategic choice as a cultural practice (Hardy \& Robin, 2014; for a broader discussion of the strategy concept see also Kryst in this volume), we maintain that we can differentiate between choices made based on strategic considerations - we call that instrumental alliance or strategy-driven cooperation - and cooperation based on shared identities, consciences or world views - we call that identitybased or culturally-driven cooperation.

"Cultural differences in organisational culture, in language, education, or traditions, can create misunderstandings between groups that undermine trust and therefore decrease the likelihood of cooperation between actors with similar strategic goals" (Flesher Fominaya, 2010, p. 17).

However, movement scholars have also highlighted different mechanisms in dealing with cultural differences and settling disagreements (e.g. Polanska et al., 2015). Most importantly, organisations need brokers or bridge builders (Tattersall, 2010), which help to connect organisations across such differences, for example by developing mutual respect and recognition of the issues and grievances of others (Beamish \& Luebbers, 2009; Brookes \& Zajak, 2018). These people help to overcome certain barriers and to construct a new sense of collective identity or, at the very least, a similar interpretation of the problem and its solution (framing). Within social movement studies, a shared identity is considered the most crucial factor for collective action. Cooperation between groups and organisations would 
not be possible without a collective actor that helps to construct imagined communities that "are able to define themselves and their relationship with the environment" (Melucci, 1995, p.43). A collective identity is perceived as being essential for cooperation, as it facilitates the formation of trust and feelings of mutual belonging (della Porta \& Diani, 2010; Melucci, 1995, 1996; Touraine, 1977).

The addition of these factors helps us to further specify our assumptions for cooperation between social movements and trade unions as follows:

Firstly, we can assume that organisations that stress differences and conceptualise social movement organisations as being different, as "others", might not cooperate, even when opportunities are present, or resources needed (Flesher Fominaya, 2010; Snow, 2001). In contrast, identities that are "highly elastic" in nature seem to facilitate cooperation, even with groups that, on the surface, do not seem to share goals and commonalities. A particularly relevant example of this is the Global Justice Movement (Flesher Fominaya, 2010). Similarly, we could speculate that organisations that stress solidarity, understood as 'perception of commonalities of interest and purpose which extend, but do not abolish, consciousness of distinct and particularistic circumstances' (Hyman, 2001, p. 170) as a strong norm, are more likely to cooperate with each other.

Secondly, there are also autonomous activist groups that reject the idea of a shared collective identity or representative politics and emphasise the role of individual expression. ${ }^{7}$ We can assume that organisations stressing autonomy and self-realization reject cooperation with most trade unions, which are the organisational expression of representative politics and collectivistic decision making.

Thirdly, groups that share similar frames are also more likely to cooperate. Frames are "interpretive schemata" used to simplify reality by "selectively punctuating and encoding" actions and events "within one's present or past environment" (Snow \& Benford, 1992, p. 137). Following Benford \& Snow's (2000) differentiation of prognostic and diagnostic framing, we assume that organisations are more likely to cooperate when they are able to define a social grievance as a problem and identify its causes ("diagnostic framing") and if they have similar strategies of problem handling ("prognostic framing").

Conversely, divergent frames, particularly when connected to identity and belief systems, ${ }^{8}$ can be a barrier in the construction of alliances between organisations. Such differences are difficult to overcome because they are based on experience and routinized social practice (Baumgarten et al., 2014), but also because values shape the understanding of legitimate and appropriate actions. As Polletta explains, "culture sets the terms of tactical choice" (Polletta, 2008, p. 86), emphasising the culturally rooted nature of more radical and moderate tactics.

Cultural differences have been researched by labour scholars in regards to trade union ideologies and, from a Marxist perspective, class-consciousness. In Industrial Relations: A Marxist Introduction, Richard Hyman defines class-consciousness as:

"the recognition that all who sell their labour in order to live, by virtue of that very fact, have common interests in opposition to those who own and control capital" (Hyman, 1975, p. 178).

7 This is why some scholars like McDonald (2002) began to argue against the concept of collective identity.

8 In contrast to frames that are constructed strategically and are defined as being a response to the context, instead of one's own ideology or belief systems. 
It is important to underscore that there is a difference between class-consciousness and class-identity, as the latter is understood as the recognition of a role as an agent of class (Hyman, 2001), but this recognition is not politically conscious enough "to challenge a class-based society" (Anderson, 1977, p. 334). This is particularly relevant when discussing the role of trade unions. Workers may acknowledge that they need to cooperate with other workers to defend their interests against the interests of the employers, but this cooperation does not necessarily lead to a questioning of capitalist society and its mode of production as a whole (Hyman, 2001). Trade unions may, but do not necessarily have to, arise due to an emerging class-consciousness (Moore, 2011) and therefore reflect different positions vis-àvis capitalism. Whether or not a union is likely to seek cooperation with social movements seems to be related to the role that class-identity plays in its ideological orientation. Hyman describes an "eternal triangle" (2001, p.3) of three ideological orientations within which all trade unions can be positioned: class opposition (where the union seeks to mobilize its membership to challenge the existing social and economic order); integrationist unionism (where the union conceives of itself as a social partner that accepts the broad constitution of society and a plurality of legitimate interests but seeks reform in the interest of its class); and business unionism (where the union defines its sphere of representation in the market) (Hyman, 2001). Frege et al. (2004) used Hyman's (2001) distinction to explain the cooperation of trade unions with social movement organisations in different countries. They observed that trade unions with class opposition background tend to prefer militancy to cooperation with capital and thus tend to build coalitions of protest with social movement organisations. Furthermore, integrationist unionism leads to a strong tendency to build coalitions, particularly coalitions of influence, where alliance partners have multiple access points and opportunities to exert influence, while business unionism oriented trade unions tend not to cooperate with social movements at all (Frege et al., 2004, p. 13). In a recent study, Andreta, Bosi, \& della Porta (2016) came to a similar conclusion on trade union and social movement cooperation in Italy. We consider the specification of the nature of organisations and their ideological positions as crucial for understanding which types of organisation tend to cooperate and which do not. Movement and trade union organisations might refrain from cooperating with each other, even if the organisations think that cooperation would increase their power or leverage, due to ideological differences or perception of the other as distinct or illegitimate. The interesting question is then, if and how such differences can be overcome through 'cooperation work', such as by reconstructing, aligning, or amplifying frames (Benford \& Snow, 2000), developing more abstract master frames (Gerhards \& Rucht, 1992) or collective identity work (e.g. "the enemy of the enemy is my friend" logic).

\section{Pathways to cooperation}

Different combinations of factors can lead to cooperation. We can, for example, assume the following. It is highly likely that organisations will cooperate if there are incentives set by the institutional environment, if resource gains can be expected, and the organisations share similar goals and world views - thus all factors (institutional incentives, resource gains and shared identities) are present (path I). On the other hand, if all these factors are absent it is 
plausible that organisations will tend to ignore each other and not cooperate (path II). However, more interesting are those cases in which we see contradictory incentives, for instance it is possible that a strong shared belief system leads to cooperation, despite an unfavourable context or expected loss of resources (path III). In contrast, the context can be open for new mobilisation and resource gains could be expected, all of which should make the strategic choices of working together likely, even if the organisations differ in terms of their world views, identities, or underlying ideologies (path IV). This reasoning follows Olson's argument on the "logic of collective action" (1965), in which he stresses that individuals make a rational decision to cooperate when they might benefit from a certain action or good which they alone could not achieve or.

This is why in our example we will focus on the paths III and IV. ${ }^{9}$ We will use the example of Alter Summit to show that developed shared identities, the belief in transnational solidarity, and shared frames against austerity politics facilitated cooperation ("identity based, culturally-driven cooperation"), in spite of how unlikely it seemed that organisations would increase their access or influence through the network. We will then use the case of protests against the Transatlantic Trade and Investment Partnership negotiations in Germany to illustrate how approaches drawn from social movement theories and labour studies can help to understand the impact of strategic choices on cooperation ("instrumental or strategy-driven cooperation").

\section{Two examples of paths to cooperation}

In the following section, we provide a brief example of each of the two cases of cooperation. The first case (Alter Summit) exemplifies cooperation primarily occurring as the result of prior shared experiences, shared interpretations, and framing of the problem ("identitybased, culturally-driven cooperation"), despite a significant lack of influence or expected resource gains. The second case, anti-TTIP mobilisation, highlights how cooperation between trade unions and social movement organisations occurred regardless of the fact that they had very different positions in terms of their overall goal and their ideological differences in relation to free trade ("instrumental or strategy-driven cooperation"). These examples should provide a brief illustration of two significantly different paths to cooperation. The illustrations are largely based on desk-research and 10 qualitative interviews with involved organisations conducted as part of a larger research project. ${ }^{10}$

9 Also interesting are cases where all factors are favorable and still no cooperation emerges and cases where everything seems to speak against cooperation but it still happens. However, these cases also seem very rare and exceptional and therefore we focus only on III and IV in this article. Other combinations of factors are also possible. For example, closed opportunities, a lack of shared identities, but the involvement of resource strong organizations willing to share those resources. Future studies could further explore different variants of these pathways and the contextual conditions under which they become relevant.

10 Research group "Transnational Alliances between Social Movements and Trade Unions. In depth case studies are still work in progress and will be presented at a later date on our project website http://www.isb.ruhruni-bochum.de/forschung/graduiertenkollegs/transnationale-allianzen/index.html.en. 


\section{Example 1: Alter Summit}

Alter Summit is a network of trade unions and social movement organisations from various European member states, founded in 2012/2013 in order "to strengthen the people's struggle against austerity and for genuine democracy". ${ }^{11}$ In the run-up to the network formation, the initiating organisations ${ }^{12}$ had known each other and worked together for many years in the European Social Forum and had subsequently built the Joint Social Forum, before forming Alter Summit as the latest attempt to consolidate their cooperation. These previous joint experiences facilitated the establishment of personal ties and gave participating organisations the time and place to develop a shared identity, attempting to build "a united movement for a democratic, social, ecological and feminist Europe". ${ }^{13}$ Alter Summit is an interesting case that highlights how collective identities developed over time, based on and a further strengthening of the belief in transnational solidarity, and shared frames opposing austerity politics.

This facilitated cooperation, contrary to what could be predicted using resource approaches (resource mobilization theory and power resource approach alike). Firstly, the development of the new network was resource consuming for all organisations: representatives had to be sent to the European meetings and financial contributions were required. For smaller and resource-poorer organisations (e.g. SAT-Andalucía) investing money, knowhow, and working hours was a challenge they had to overcome. Secondly, the network offered few opportunities for national trade unions to increase institutional, associational, or discursive power resources. Trade unions engaged the European Union, where neither national unions, nor social movement organisations, have significant access to the political processes. Some social movement organisations might have gained material resources through cooperation with big national trade unions in the Alter Summit network, but they could not increase their institutional access or discursive visibility either. On the contrary, cooperating with unions is difficult for some movement organisations (e.g. some 15-M initiatives), as some perceive trade unions as an auxiliary part of the capitalistic system. For trade unions, it was unlikely that they would gain more members or discursive power, as Alter Summit was not well known and did not significantly engage in public campaigning or the organisation of public protest. On the contrary, trade unions could lose public legitimacy by using an alternative channel of cooperation beside the European Trade Union Confederation (ETUC). Thirdly, the joint framing against austerity politics presented a challenge for some of the organisations involved, as austerity-measures affected countries differently and, for the most part, not at all. Of the 22 countries from which the Alter Summit organisations come from, only Spain, Greece and Portugal ${ }^{14}$ were directly affected by austerity policy.

11 Alter Summit, 2012: Functioning, Retrieved from: http://www.altersummit.eu/alter-sommet/article/functionning, searched on 10.12.2017.

12 Some of the key-organisations: transform! europe, CNE, FGTB, ATTAC-France, CGT, ATTAC-Deutschland, Nicos Poulantzas Institute, TNI, ATTAC-Spain, CC.OO., AEDH.

13 Alter Summit, 2013: The Manifesto, Retrieved from: http://www.altersummit.eu/manifeste/article/themanifesto, searched on 24.01.2018.

14 Ireland and Cyprus were also affected by austerity policy but there are no Alter Summit member organisations from these countries. 
To understand why organisations still invested their resources in the Alter Summit network, we must take a closer look at the cultural and contextual factors. The founding organisations of the network had years of joint work in which to converge their ideological background and to develop shared framings regarding the causes of the crisis (which started in 2007/2008, years before Alter Summit was created), interpreting it as a systemic crisis of capitalism. During international gatherings of leftist movements, networks, and organisations such as Florence $10+10$ in 2012, founding organisations of Alter Summit had the opportunity to develop shared prognostic framings, looking for collective strategies to assisted the fight against the austerity crisis. These interactions helped to construct the shared understanding that building a European network where having diverse organisations "support[ing] and strengthen[ing] each other's struggles" was an important step en route to stopping austerity and challenging the European balance of power. ${ }^{15}$ The European debt crisis and the prevalent austerity measurements gave them plausible opportunity to consolidate their cooperation, rooted in the belief that a European network between "different types of organisations and movements, especially trade unions, social movements and networks of researchers and institutes" is necessary, with the goal "to effectively influence and exert all its weight on the EU policies". ${ }^{16}$

However, a shared perspective on the crisis, ideological closeness and a belief in transnational solidarity were not enough to maintain cooperation, at least not for German trade unions like GEW, IG Metall, Verdi and DGB youth. Although involved in the social forums prior to and at the beginning of Alter Summit, they left the network after a few meetings as they began to view it as being ineffective. They were not only dissatisfied with the meagre media attention that the new network attracted, they also perceived the other participating organisations as being insignificant, meaning that the symbolic power resources they apparently anticipated were lacking. Additionally, for strategic reasons and in order to maintain their associational power resources among their members, they perceived the ETUC to be a more legitimate European channel for political action. This suggests that integrationist unions (like GEW, Verdi \& IG Metall) prefer to cooperate with social movements in instrumental coalitions, while cultural factors continue to hold the rest of the network together.

\section{Example two: Anti-TTIP Mobilization}

To illustrate how approaches from social movement theories and labour studies can help to understand strategy-driven cooperation we will now look at the protest march against the Transatlantic Trade and Investment Partnership (TTIP) in Berlin, Germany on October $10^{\text {th }}$, 2015.

Negotiations regarding a trade and investment agreement between the European Union and the United States started in 2013. The European Commission believed that TTIP would not only provide a boost for the economy, including growth in jobs, especially of those in

15 Alter Summit, 2013: The Manifesto, Retrieved from: http://www.altersummit.eu/manifeste/article/themanifesto, searched on 24.01.2018.

16 Alter Summit, 2012: Functioning, Retrieved from:

http://www.altersummit.eu/alter-sommet/article/functionning, searched on 10.12.2017. 
export-oriented industries (European Commission, 2013), but also that it would "set the standard - not only for our future bilateral trade and investment but also for the development of global rules" (European Commission, 21.02.2013). Numerous organisations, networks, and groups of the civil society in several European countries shared the belief that TTIP would set a standard but were not in agreement with the European Commission's positive assessment. In Germany, an exceptionally large and heterogeneous alliance emerged, criticising the lack of transparency during the negotiations and, in part, the agreement itself. The alliance mobilised in the form of a European Citizen Initiative (ECI) and several large protest marches, against the passage of TTIP and for transparent and democratically controlled negotiations (European Initiative against TTIP and CETA; Trägerkreis Großdemonstration am 10. Oktober 2015 in Berlin, 29.08.2015; Trägerkreis der bundesweiten Großdemonstrationen "CETA \& TTIP STOPPEN! - Für einen gerechten Welthandel!"). The alliance in Germany was particularly surprising as Germany, the forerunner in export, stood to reap significant benefits from TTIP and German trade unions, supporters of the export orientation of the German industry, seemed unlikely to join mass protest against TTIP. And yet the alliance that organised the largest protest in Berlin on October $10^{\text {th }}, 2015$ consisted of, among others, the German Trade Union Confederation (Deutscher Gewerkschaftsbund, DGB), Attac Germany, Brot für die Welt (a developmental aid organisation affiliated with the Protestant church), Naturfreunde Deutschland (an organisation with roots in the socialist and environmental movement), Greenpeace, Mehr Demokratie (which lobbies for more direct democracy elements in German politics), and Arbeitsgemeinschaft Bäuerliche Landwirtschaft (ABL - the German member of the global network of the peasants' movement, Via Campesina). These organisations hardly shared a collective identity or classconsciousness and the cooperation also did not seem to build on common ideologies or worldviews. Even the frames regarding TTIP itself are heterogeneous as some of the organisations renounce free trade outright and therefore aim to prevent TTIP (e.g. NaturFreunde Deutschland; Attac), while other organisations, for example the DGB, do not reject trade agreements in general, but demanded a modification of TTIP (Gegenblende das DGBDebattenportal, 2015). The lowest common denominator might be found in the shared belief in the need to intervene in the TTIP negotiations. To understand why and which organisations cooperated based on such a small common ground, it is necessary to take context and resources into account.

At first glance, no cooperation would be indicated based on the contextual factors from both social movement and industrial relations studies: German trade unions of the DGB continue to be embedded in social partnership institutions and Germany still counts as a coordinated market economy, where trade unions would seek influence through institutional channels rather than through public protest. Also, from a resource perspective, it seems unlikely that they would gain more members, increased access, or any kind of material resources by cooperating with social movement organisations in joint protest events. Even their legitimacy and discursive power could be at stake given that the DGB is involved in Labour20, a Network of trade unions trying to represent trade unions' demands within the G20 and supports the Trade Union Advisory Council (TUAC) of the OECD. Therefore, in other trade related contexts the DGB seeks to be perceived as a legitimate voice within consultations, as opposed to protesting and questioning the legitimacy of these consultations. 
To understand why trade unions and social movements cooperated nonetheless, the concept of shared grievances can offer possible explanations: the original TTIP proposal included an Investor-State-Dispute-Settlement (ISDS) mechanism and regulatory cooperation which were both perceived to be an extraordinary threat to democracy not only at a European, but also at a national, level (European Initiative against TTIP and CETA). These mechanisms could affect every area of legislation, from labour law to consumers' rights and environmental protection, and created an opportunity for a large alliance of various social movements and organisations. For the German trade unions this threat may have had significant weight, as it could have potentially undermined their institutional power resources at the national level. Another shared grievance can be seen in the negotiation process itself, which started out as a very secretive process, taking measures to keep documents of the negotiation content confidential (arrangements on TTIP negotiating documents, 05.07.2013), thereby making it almost impossible for trade unions, as well as for social movements, to gain access to detailed information. These specific circumstances of trade negotiation may have made it impossible for the German trade unions to rely on their institutional power resources, thus creating an incentive to ally with social movements in order to strengthen their discursive power resources. For the social movement organisations involved, cooperation with the German trade unions meant benefitting from a huge increase in resources in terms of outreach and infrastructure. For example, the organisation of busses and mobilisation of union members contributed to the size of the TTIP protest in Germany.

The position of the unions may have been influenced by a third factor: though they can be perceived as following the integrationist model, their link to the Social Democratic Party (SPD) has weakened (Dribbusch \& Birke, 2014). Given that the SPD had been part of the governing coalition during the negotiations, and that their chairman, Sigmar Gabriel, had been heavily in favour of TTIP, German trade unions may have had another incentive to search for new allies outside the party system. At the same time, it is possible that social movements may have speculated that old ties between German trade unions and the Social Democratic Party could help to influence the European Parliament and German government, thus perceiving unions to be, partially, insiders.

Finally, cooperation mainly took place between "resource similar" organisations, just as resource mobilisation theory predicts. Trade unions cooperated with large and relatively formal social movement organisations like Attac, BUND, and Campact. The organisational similarities probably facilitated bridge building across the ideational differences of social movements and trade unions vis-à-vis globalization, global governance and trade.

These brief illustrations of two cases show that the factors that explain cooperation can be very different, depending on the specific actor constellation and setting - an aspect which receives little consideration in conceptualizations of social movement unionism.

\section{Conclusion}

This paper examined prominent theories within social movement studies and industrial relations in order to theorise and hypothesise factors and conditions that influence cooperation between social movement organisations and trade unions. We departed from earlier studies, 
which looked into cooperation through the particular viewpoint of either industrial relations or social movement theories. Our paper contributes to increasing the understanding of cooperation between social movement organisations and trade unions by further integrating various analytical dimensions of both social movement and industrial relations theory (Grote \& Wagemann, 2019). We used concepts and indicators from both theories to distinguish between different pathways to and drivers of cooperation, resulting from different combinations of these factors. We chose two cases to highlight the differences between instrumental, strategy-driven cooperation and identity-based, culturally-driven cooperation. Our results suggest that we cannot simply assume that a shared identity or shared strategic goals are necessary conditions for cooperation; both aspects are important, but to varying degrees under different circumstances. Thus, different paths to cooperation are possible and more systematic and comparative research, within and across countries, is needed in order to be more precise about the specific combination of factors leading to cooperation or the breaking of alliances. The outline of the different pathways suggested in this paper could be a first step towards such a comparison, which future studies can explore. Further research is imperative as it increases our understanding of how different organisational forms can cooperate with each other, even across cleavage structures or deep ideological divides. Such cross-organisational and cross-ideological cooperation is paramount in ostensibly increasingly fragmented societies.

\section{Bibliography}

Alter Summit (2012). Functioning. Abgerufen von http://www.altersummit.eu/alter-sommet/article/functionning

Alter Summit (2013). The Manifesto. Abgerufen von http://www.altersummit.eu/manifeste/article/the-manifesto

Anderson, P. (1977). The Limits and possibilities of Trade Union Action. In T. Clarke \& L. Clemens (eds.), Trade Unions under Capitalism. Glasgow: Fontana.

Andreta, M., Bosi, L. \& della Porta, D. (2016). Participants in trade union-staged demonstrations: a cross-country comparison. Transfer: European Review of Labour and Research, 22 (3), 295-313. doi: $10.1177 / 1024258916657991$

Andrews, K. T., Edwards, B., Al-Turk, A. \& Hunter, A. K. (2016). Sampling Social Movement Organisations. Mobilization: An International Quarterly, 21 (2), 231-246. doi: 10.17813/1086-671X-21-2-231

Arbeitskreis Strategic Unionism (2013). Jenaer Machtressourcen Ansatz 2.0. In S. Schmalz \& K. Dörre (eds.), Comeback der Gewerkschaften? Machtressourcen, innovative Praktiken, internationale Perspektiven (S. 345-376). Frankfurt, New York: Campus Verlag.

Arrangements on TTIP negotiating documents (2013). Letter from Ignacio Garcia Bercero, Chief EU Negotiator for TTIP, to L. Daniel Mullaney, Chief US Negotiator for TTIP; Brussels: European Commission. Abgerufen von http://trade.ec.europa.eu/doclib/docs/2013/july/tradoc_151621.pdf

Attac Deutschland (o. J.). TTIP \& CETA etc. in die Tonne! Abgerufen von http://www.attac.de/kampagnen/freihandelsfalle-ttip/freihandelsfalle-ttip/

Barker, C., Cox, L., Krinsky, J. \& Nilsen, A.(eds.). (2013). Marxism and Social Movements. Leiden: Brill. doi: 10.1002/9780470674871.wbespm123

Baumgarten, B. (2014). Culture and Activism across Borders. In B. Baumgarten, P. Daphi \& P. Ullrich, Conceptualizing Culture in Social Movement Research (S. 91-113). London: Palgrave Macmillan. doi: 10.1057/9781137385796 
Beamish, T. D. \& Luebbers, A. J. (2009). Alliance Building across Social Movements: Bridging Difference in a Peace and Justice Coalition. Social Problems, 56 (4), 647-676. doi: $10.1525 /$ sp.2009.56.4.647

Benford, R. D. \& Snow, D. A. (2000). Framing Processes and Social Movements: An Overview and Assessment. Annual Reviews Sociology, 26, 611-639.

doi: 10.1146/annurev.soc.26.1.611

Berger, S., Pries, L. \& Wannöffel, M. (2018). The Palgrave International Handbook of Workers' Participation. London: Palgrave MacMilan.

Bernaciak, M., Gumbrell-McCormick, R. \& Hyman, R. (2014). Trade Unions in Europe, Innovative Responses to Hard Times. Berlin: Friedrich Ebert Stiftung.

Bieler, A., Erne, R., Golden, D., Helle, I., Kjeldstadli, K., Matos, T. \& Stan, S. (eds.). (2015). Labour and Transnational Action in Times of Crisis. London: Rowman\&Littlefield.

Brookes, M. (2013). Varieties of Power in Transnational Labor Alliances: An Analysis of Workers' Structural, Institutional, and Coalitional Power in the Global Economy. Labor Studies Journal, 38 (3), 181-200. doi: 10.1177/0160449X13500147

Buechler, S. M. (1993). Beyond Resource Mobilization? Emerging Trends in Social Movement Theory. Sociological Quarterly, 34, 217-235. doi: 10.1111/j.1533-8525. 1993.tb00388.x

Caniglia, B. \& Carmin, J. (2010). Scholarship on social movement organisations: Classic views and emerging trends. Mobilization: An International Journal, 10 (2), 201-212.

Choi, H. \& Mattoni, A. (2010). The contentious field of precarious work in Italy: political actors, strategies and coalitions. Journal of Labor and Society, 13 (2), 213-243. doi: $10.1111 / \mathrm{j} .1743-4580.2010 .00284 . x$

Chun, J. J. (2009). Organising at the Margins: The Symbolic Politics of Labour in South Korea and the United States. Ithaca: Cornell University Press. doi: 10.7591/9780801458453

Della Porta, D., Fernández, J., Kouki, J. \& Mosca, L. (2017). Movement Parties Against Austerity. Cambridge: Polity Press.

Della Porta, D. (2015). Social Movements in Times of Austerity: Bringing Capitalism Back into Protest Analysis. Cambridge, Malden: Polity Press. doi: 10.1086/686050

Della Porta, D. \& Diani, M. (2010). Social Movements: An Introduction (2. ed.). Oxford: WileyBlackwell.

Diani, M. (1992). The concept of social movement. The Sociological Review, 40, 1-25. doi: 10.1111/j.1467-954X.1992.tb02943.x

Diani, M. (2015). The cement of civil society: studying networks in localities. Cambridge: Cambridge University Press. doi: 10.1017/CBO9781316163733

Diani, M. \& McAdam, D. (2003). Social movements and networks: Relational approaches to collective action. Oxford: Oxford University Press. doi: 10.1093/0199251789.001.0001

Dörre, K. \& Schmalz, S. (2013). Comeback der Gewerkschaften? Machtressourcen, innovative Praktiken, internationale Perspektiven. Frankfurt/New York: Campus.

Dörre, K., \& Schmalz, S. (2014). Der Machtressourcenansatz: Ein Instrument zur Analyse gewerkschaftlichen Handlungsvermögens. Industrielle Beziehungen. The German Journal of Industrial Relations, 21 (3), 217-237. doi: 10.1688/IndB-2014-03-Schmalz

Dribbusch, H. \& Birke, P. (2014). Die DGB-Gewerkschaften seit der Krise. Entwicklungen, Herausforderungen, Strategien. Friedrich Ebert Stiftung. Abgerufen von www.fes-centralasia.org/files/assets/publikationen/GEW_DT_de.pdf

Dunlop, J. T. (1993 [1958]). Industrial relations systems. Boston: Harvard Business School Press.

Eggert, N. \& Giugni, M. (2015). Does the class cleavage still matter? The social composition of participants in demonstrations addressing redistributive and cultural issues in three countries. International Sociology, 30 (1), 21-38. doi: 10.1177/0268580914555935 
Etzioni, A. (1968). The Active Society. New York: Free Press.

European Commission (2013). Transatlantic Trade and Investment Partnership: Opening free trade negotiations with the United States. Published version of a Speech by Karel de Gucht. Abgerufen von http://trade.ec.europa.eu/doclib/docs/2013/february/tradoc_150581.pdf

European Initiative against TTIP and CETA (o. J. a). Alliance. Abgerufen von https://stop-ttip.org/supporting-organisations/?noredirect=en_GB

European Initiative against TTIP and CETA. (o. J. b). Short Introduction. Abgerufen von https://stop-ttip.org/what-is-the-problem-ttip-ceta/?noredirect=en_GB

Flesher Fominaya, C. (2010). Collective Identity in Social Movements: Central Concepts and Debates. Sociology Compass, 4 (6), 393-404. doi: 10.1111/j.1751-9020.2010.00287.x

Fletcher, B. \& Gapasin, F. (2008). Solidarity Divided. Berkeley: University of California Press.

Fogarty, E. (2013). States, Nonstate Actors, and Global Governance: Projecting Polities. New York: Routledge.

Ford, M. (2009). Workers and Intellectuals. NGOs, Trade Unions and the Indonesian Labour Movement. Singapore: NUS Press.

Frege, C. M. \& Kelly, J. (2003). Union Revitalization Strategies in Comparative Perspective. European Journal of Industrial Relations, 9 (1), 7-24. doi: 10.1177/095968010391002

Frege, C. Heery, E., \& Turner, L. (2004). The New Solidarity? Trade Union Coalition-Building in Five Countries. Abgerufen von http://digitalcommons.ilr.cornell.edu/articles/1008

Frege, C. M. \& Kelly, J. (eds.). (2004). Varieties of Unionism: Strategies for Union Revitalization in a Globalizing Economy. Oxford: Oxford University Press. doi: 10.1093/acprof:oso/9780199270149.001.0001

Gallas, A. (2015). Politisierte Streiks: Zur Dynamik und Deutung von Arbeitskämpfen in Großbritannien. Arbeits- und Industriesoziologische Studien, 8 (2) 67-91.

Gamson, W. \& Meyer, D. (1996). Framing Political Opportunity. In D. McAdam, J. McCarthy, \& M. Zald (eds.), Comparative Perspectives on Social Movements: Political Opportunities, Mobilizing Structures, and Cultural Framing (S. 275-90). Cambridge: Cambridge University Press. doi: $10.1017 / \mathrm{CBO} 9780511803987.014$

Gegenblende das DGB-Debattenportal (2015). TTIP: Gemeinsam regeln, statt deregulieren. Abgerufen von http://gegenblende.dgb.de/34-2015/++co++f3888362-6119-11e5-b892-52540066f352

Gerhards, J. \& Rucht, D. (1992). Mesomobilization. Organizing and Framing in Two Protest Campaigns in West Germany. American Journal of Sociology, 98, 555-596. doi: 10.1086/230049

Goldstone, J. \& Tilly, C. (2001). Threat (and opportunity): popular action and state responses in dynamics of contentious action. In R. Aminzade et al. (eds.), Silences and Voices in the Study of Contentious Politics (S. 179-94). Cambridge: Cambridge University Press. doi: 10.1017/CBO9780511815331.008

Grote, J. R. \& Wagemann, C. (forthcoming 2019). Social Movements and Organised Labour: Passions and Interests. New York: Routledge.

Gumbrell-McCormick, R. \& Hyman, R. (2013). Trade unions in Western Europe: Hard times, hard choices. Oxford: Oxford University Press. doi: 10.1093/acprof:oso/9780199644414.001.0001

Hardy, C. \& Robyn, T. (2014). Strategy, Discourse and Practice: The Intensification of Power. Journal of Management Studies, 51 (2), 320-348. doi: 10.1111/joms.12005

Hellmann, K.-U. \& Koopmans, R. (eds.). (1998). Paradigmen der Bewegungsforschung. Opladen: Westdeutscher Verlag. doi: 10.1007/978-3-663-10990-7

Hooghe, L. \& Marks, G. (2018). Cleavage theory meets Europe's crises: Lipset, Rokkan, and the transnational cleavage. Journal of European Public Policy, 25 (1), 109-135.

doi: $10.1080 / 13501763.2017 .1310279$ 
Hyman, R. (1975). Industrial Relations: A Marxist Introduction. London: Macmillan. doi: 10.1007/978-1-349-15623-8

Hyman, R. (2001). Understanding European Trade Unionism: Between market, class and society. London: Sage.

Ibsen, C. L. \& Tapia, M. (2017). Trade union revitalisation: Where are we now? Where to next? Journal of Industrial Relations, 59 (2), 170-191. doi: 10.1177/0022185616677558

Jackson, G., Kuruvilla, S. \& Frege, C. (2013). Across Boundaries: The Global Challenges Facing Workers and Employment Research. British Journal of Industrial Relations, 51 (3), 425-439. doi: 10.1111/bjir.12039

Jansen, J. (2013). From movement to organization: constructing identity in Swedish trade unions. Labor History, 54 (3), 301-320. doi: 10.1080/0023656X.2013.809925

Jenkins, J. C. (1983). Resource Mobilization Theory and the Study of Social Movements. Annual Reviews of Sociology, 9 (5), 527-553. doi: 10.1146/annurev.so.09.080183.002523

Kanellopoulos, K., Kostopoulos, K., Papanikolopoulos, D. \& Rongas, V. (2017). Competing modes of coordination in the Greek anti-austerity campaign, 2010-2012. Social Movement Studies, 16 (1), 101-118. doi: 10.1080/14742837.2016.1153464

Kelly, J. (1997). The future of trade unionism: injustice, identity and attribution. Employee Relations, 19 (5), 400-414. doi: 10.1108/01425459710186296

Kelly, J. (1998). Rethinking Industrial Relations: Mobilisation, Collectivism and Long Waves. London: Routledge. doi: 10.4324/9780203213940

Kendall, D. (2005). Sociology in our time. Stamford: Cengage Learning.

Kriesi, H. (2004). Political Context and Opportunity. In H. Kriese, D. Snow \& S. Soule (eds.), The Blackwell Companion to Social Movements (S. 67-90). Oxford: Blackwell Pubishing Ltd. doi: 10.1002/9780470999103.ch4

Kriesi, H., Grande, E., Dolezal, M., Helbling, M., Höglinger, D., Hutter, S. \& Wüest, B. (2012). Political conflict in western Europe. Cambridge: Cambridge University Press. doi: 10.1017/CBO9781139169219

Lipset, S. M. \& Stein R. (eds.). (1967). Party Systems and Voter Alignments: Cross-National Perspectives, New York, London: Free Press.

Mathers, A., Upchurch, M. \& Taylor, G. (2019). Social movement theory and trade union organizing. In: G. Grote \& C. Wagemann (eds.), Social Movements and Organised Labour: Passions and Interests. New York: Routledge.

McAdam, D., McCarthy, J. \& Zald, M. (eds.). (1996). Comparative Perspectives on Social Movements: Political Opportunities, Mobilizing Structures, and Cultural Framings. New York: Cambridge University Press. doi: 10.1017/CBO9780511803987

McCarthy, J. D. \& Walker, E.T. (2010). Legitimacy, Strategy, and Resources in the Survival of Community-Based Organisations. Social Problems, 57 (3), 315-340. doi: $10.1525 / \mathrm{sp} .2010 .57 .3 .315$

McDonald, K. (2002). From Solidarity to Fluidarity: Social movements beyond 'collective identity' the case of globalization conflicts. Social Movement Studies, 1 (2), 109-128. doi: 10.1080/1474283022000010637

McGuire, D. (2013). Re-Framing Trade Union Mobilisation against the General Agreement on Trade in Services (GATS). München: Rainer Hampp Verlag.

McPherson, M., Smith-Lovin, L. \& Cook; J. M. (2001). Birds of a Feather: Homophily in Social Networks. Annual Review of Sociology, 27 (1), 415-444. doi: 10.1146/annurev.soc.27.1.415

Melucci, A. (1995). The Process of Collective Identity. In H. Johston \& B. Klandermans (eds.), Social Movements (S. 41-63). Minneapolis: University of Minnesota Press. 
Melucci, A. (1996). Challenging Codes: Collective Action in the Information Age. Cambridge: Cambridge University Press. doi: 10.1017/CBO9780511520891

Meyer, D. S. (2004). Protest and Political Opportunities. Annual Review of Sociology, 30 (1), 125145. doi: 10.1146/annurev.soc.30.012703.110545

Meyer, D. S. \& Minkoff, D. C. (2004). Conceptualizing Political Opportunity. Social Forces, 82 (4), 1457-1492. doi: $10.1353 /$ sof.2004.0082

Moore, S. (2011). New Trade Union Activism. Class Consciousness or Social Identity. London: Palgrave Macmillan. doi: 10.1057/9780230294806

Müller-Jentsch, W. (1995). Auf dem Prüfstand: das deutsche Modell der industriellen Beziehungen. Industrielle Beziehungen. The German Journal of Industrial Relations, 2 (1), 11-24.

NaturFreunde Deutschland (2017). Beschluss des 30. ordentlichen Bundeskongresses der NaturFreunde Deutschlands. Abgerufen von https://www.naturfreunde.de/freihandelsabkommen-stoppen-fuer-eine-gerechte-weltwirtschaft

Nowak, J. (2017). Mass Strikes in India and Brazil as the Terrain for a New Social Movement Unionism. Development and Change, 48 (5), 965-986.

Olson, M. (1965). The Logic of Collective Action: Public Goods and the Theory of Groups, Second printing with new preface and appendix Harvard University Press.

Polanska, D. V. \& Piotrowski, G. (2015). The transformative power of cooperation between social movements: Squatting and tenants' movements in Poland. City, 19 (2-3), 274-296. doi: 10.1080/13604813.2015.1015267

Polletta, F. (2008). Culture and Movements. The ANNALS of the American Academy of Political and Social Science, 619 (1), 78-96. doi: 10.1177/0002716208320042

Pries, L. (2010). Erwerbsregulierung in einer globalisierten Welt. Wiesbaden: VS, Verlag für Sozialwissenschaften. doi: 10.1007/978-3-531-91956-0

Rehder, B. (2018). Revitalisierung der Gewerkschaften? Die Grundlagen amerikanischer Organisierungserfolge und ihre Übertragbarkeit auf deutsche Verhältnisse. Berliner Journal für Soziologie, 18 (3), 432-456. doi: 10.1007/s11609-008-0029-0

Rogers, M. (1974). Instrumental and infra-resources. American Journal of Sociology, 79 (6), 1418 1433.

doi: $10.1086 / 225708$

Roose, J., Sommer, M. \& Scholl, F. (eds). (2018). Protest, Resilienz und Kämpfe um Deutungshoheit. Europas Zivilgesellschaft in der Wirtschafts- und Finanzkrise. Wiesbaden: Springer VS.

Rucht, D. (2004). Movement Allies, Adversaries, and Third Parties. In D. A. Snow, S. A. Soule \& H. Kriesi (eds.), The Blackwell Companion to Social Movements (S. 197-216). Malden, Oxford, Carlton: Blackwell Publishing. doi: 10.1002/9780470999103.ch9

Rucht, D. (2017). Studying Social Movements: Some Conceptual Challenges. In S. Berger et al. (eds.), The History of Social Movements in Global Perspective (S. 39-62). London: Palgrave Macmillan. doi: 10.1057/978-1-137-30427-8_2

Rucht, D. \& Roth, R. (eds.) (2007). Die Sozialen Bewegungen in Deutschland seit 1945: Ein Handbuch. Frankfurt a. M.: Campus.

Silver, B. (2003). Forces of Labor: Workers' Movements and Globalisation since 1870. Cambridge/New York: Cambridge University Press. doi: 10.1017/CBO9780511615702

Snow, D. (2001). Collective Identity and Expressive Forms. CSD Working Papers. Abgerufen von http://escholarship.org/uc/item/3vs886v9.pdf doi: 10.1016/B0-08-043076-7/04094-8

Snow, D. A. \& Benford, R. D. (1992). Master frames and cycles of protest. In A. D. Morris \& C. McClurg Mueller (eds.), Frontiers in social movement theory (S. 133-155). New Haven, London: Yale University Press. 
Tarrow, S. (1996). Social Movements in Contentious Politics: A Review Article. The American Political Science Review, 90 (4), 874-883. doi: 10.2307/2945851

Tattersall, A. (2010). Power in Coalition. Ithaca, NY: ILR Press.

Tilly, C. (1978). From Mobilization to Revolution. Massachusetts: Addison-Wesley.

Touraine, A. (1977). The Self-Production of Society. Chicago: The University of Chicago Press.

Trägerkreis der bundesweiten Großdemonstrationen "CETA \& TTIP STOPPEN! - Für einen gerechten Welthandel!”. (o. J.). Trägerkreis der bundesweiten Großdemonstrationen in sieben Städten in Berlin, Frankfurt/Main, Hamburg, Köln, Leipzig, München und Stuttgart am 17. September 2016. Abgerufen von http://ttip-demo.de/home/netzwerk/

Trägerkreis Großdemonstration am 10. Oktober 2015 in Berlin (29.08.2015). Abgerufen von https://web.archive.org/web/20150829174039/http://ttip-demo.de:80/home/netzwerk/

TTIP Unfairhandelbar (o. J.). Mitgliederliste. Abgerufen von http://www.ttip-unfairhandelbar.de/start/wer-wir-sind/mitgliederliste/\#V-Anker

Turner, L. (2006). Globalization and the logic of participation: Unions and the politics of coalition building. Journal of Industrial Relations, 48 (1), 83-97. doi: 10.1177/0022185606059315

Urban, H.-J. (2010). Niedergang oder Comeback der Gewerkschaften. Aus Politik und Zeitgeschichte. 13-14 (60), 3-7.

Webster, E. (2015). Labour after Globalisation: Old and New Sources of Power. ISER Working Paper No. 2015/1.

Webster, E., Lambert, R. \& Bezuidenhout, A. (2008). Grounding Globalization: Labour in the Age of Insecurity. London: Blackwell. doi: 10.1002/9781444303018

Wright, E. O. (2000). Working-Class Power, Capitalist-Class Interests and Class Compromise. The American Journal of Sociology, 105 (4), 957-1002. doi: 10.1086/210397

Yon, K. (2016). A long-awaited homecoming: the labour movement in social movement studies. In O. Fillieule \& G. Accornero (eds.), Social movement studies in Europe: the state of the art (S. 54-68). New York, Oxford: Berghahn.

Zajak, S. (2019). Social movements and trade unions in cross-movement counter mobilization. A Polanyian view on social movement and trade union cooperation. In J.R. Grote \& C. Wagemann (eds.), Social Movements and Organized Labour. Passions and Interests. The Mobilization Series on Social Movements, Protest and Culture. Surrey: Ashgate Verlag.

Zajak, S. (2017). Institutional Layering and the Emerging Power of Labour in Bangladesh. Development and Change 48 (5), 1007-1030. doi: 10.1111/dech.12327

Zajak, S., Piper, N. \& Egels-Zanden, N. (2017). Introduction: Networks of Labour: Collective Action across Asia and Beyond. Development and Change, 48 (5), 899-921. doi: 10.1111/dech.12336 


\section{Transnational Social Movement Unionism als Vitalisierungsstrategie und Chance für Gewerkschafterinnen? Das Beispiel des Bekleidungssektors Bangladeschs}

\section{Zusammenfassung}

Der Beitrag analysiert die Chancen und Grenzen eines transnationalen Social Movement Unionism (SMU) im Kontext des Bekleidungssektors Bangladeschs. SMU galt in Bangladesch insbesondere aufgrund des Prozesses der Depolitisierung zivilgesellschaftlicher Organisationen im Anschluss an die AidDependency des Landes als kaum realisierbar. Unberücksichtigt blieb hierbei aber weitestgehend die Rolle der Kategorie Geschlecht. Vor dem Hintergrund meines empirischen Materials, das zwischen 2010 und 2015 in Form von Interviews mit Angehörigen von Gewerkschaften und Labour-NGOs erhoben wurde, argumentiere ich, dass erste Ansätze von SMU erkennbar sind. Darüber hinaus zeigt der Blick auf den Bekleidungssektor Bangladeschs, dass das Potenzial dieses Organisierungskonzeptes sich insbesondere mit Blick auf die Arbeiterinnen und Gewerkschafterinnen offenbart. Ferner wird anhand dieses empirischen Beispiels die transnationale Rahmung des Arbeitsrechtsaktivismus verdeutlicht, der sich vom SMU der 1980er Jahre deutlich unterscheidet und als wegweisende Perspektive zu grenzüberschreitender Kooperation dienen kann. Nichtsdestotrotz hinterfragt der Beitrag die Notwendigkeit einer geographischen Lokalisierung des gegenwärtigen SMU und plädiert vielmehr für eine stärkere Berücksichtigung gesellschaftlicher Strukturkategorien innerhalb der Labour Studies sowie für eine größere Wachsamkeit gegenüber Organisierungsformen jenseits des traditionellen gewerkschaftlichen Musters.

Schlagwörter: Bangladesch, Bekleidungssektor, Social Movement Unionism, Gender

\section{Transnational Social Movement Unionism as a Revitalisation Strategy and Chance for Female Trade Unionists? A Case Study from Bangladesh's Ready-made Garment Sector}

\section{Abstract}

The paper analyses the opportunities and limits of Social Movement Unionism (SMU) in the context of the Bangladeshi garment sector. In the past, the concept of SMU was considered unrealistic in

\footnotetext{
* Elisabeth Fink, Gunta-Stölzl-Str. 23, 80807 München. E-Mail: lisfink@yahoo.com

** Artikel eingegangen: 30.8.2017, revidierte Fassung akzeptiert nach doppelt-blindem Begutachtungsverfahren: 8.3.2018
} 
Bangladesh, largely because of the de-politicization of civil society organizations, a result of the country's dependency on aid. The role of gender in relation to SMU in Bangladesh, however, remains on the whole ignored. Drawing on interviews with trade unionists and representatives of labour NGOs, conducted between 2010 and 2015, I argue evidence prevails to suggest that some aspects of SMU prevail. Furthermore, the role of female workers and trade unionists highlights the organizing potential of transnational SMU. In addition, the paper describes how the transnational framing of workers' rights activism, which differs from the SMU of the 1980s, might serve as an example for establishing solidarity across national borders. The contribution, however, questions the fixed geographical framings of current forms of SMU and instead emphasizes the importance of analyzing different social categories as well as paying more attention towards organizing beyond the traditional union model.

Key words: Bangladesh, Ready-made garment sector, Social Movement Unionism, Gender (JEL: F54, F66, J51, J83, L31, N35, P16)

\section{Einleitung: Social Movement Unionism in Bangladesch?}

Eine Kooperation zwischen transnationalen NGOs (TNGOs) ${ }^{1}$ und Gewerkschaften scheint im Kontext des Bekleidungssektors Bangladeschs zunächst nahezuliegen: Die schwachen Gewerkschaften können seit der Etablierung des Sektors in den 1980er Jahren keine nennenswerten Mitgliederzahlen vorweisen, (T)NGOs engagieren sich jedoch zunehmend im Sektor. Allianzen zwischen (T)NGOs und Gewerkschaften werden gleichwohl von Seiten der Gewerkschaften äußerst kritisch betrachtet. Sie befürchten eine NGOisierung der Gewerkschaftsbewegung. Im Zusammenhang mit der Aid-Dependency des Landes ${ }^{2}$ konnten sie beobachten, dass eine NGOisierung von Bewegungen mehrheitlich in deren Depolitisierung mündete (vgl. Nazneen, 2017; Kabeer, Mahmud \& Isaza Castro, 2010; Feldman 2003). Zusätzlich zu den ohnehin vorhandenen Spannungen zwischen diesen beiden Organisationsformen tritt im Kontext des Bekleidungssektors Bangladeschs demnach die ,double divide" (Anner \& Evans, 2004) zwischen dem globalen Norden und Süden folgendermaßen in Erscheinung: NGOs aus dem globalen Norden stehen unter dem Verdacht der hegemonialen Einhegung, des Boykotts und Protektionismus, des US-Imperialismus oder neokolonialer Dominanz. Gewerkschaften, die sich im linksradikalen politischen Spektrum verorten, lehnen eine Kooperation mit NGOs daher kategorisch ab. Nichtsdestotrotz liegen

1 Ich verwende die zunehmend geläufigere Bezeichnung, transnationale` statt, internationale “ NGO (TNGO statt INGO). Während der Begriff ,international ‘ im Forschungsfeld der Internationalen Beziehungen insbesondere für die Beziehungen zwischen Staaten verwendet wird, beschreibt der Begriff ,transnational ${ }^{\star}$ vielmehr Interaktionen auf nicht-staatlicher Ebene (vgl. Pries, 2010, S. 13). Die Bezeichnung TNGO wird somit im Gegensatz zu INGO dem zivilgesellschaftlichen und somit nicht-gouvernementalen Charakter dieser Organisationsform gerechter. Gleichwohl handelt es sich bei diesen Abgrenzungen (zivilgesellschaftlich vs. gouvernemental) um Idealtypen. Beispielsweise stehen NGOs vielfach in einem direkten finanziellen Abhängigkeitsverhältnis zum Staat.

2 Zum Zeitpunkt seiner Gründung im Jahr 1971 war der Staat Bangladesch vollends von sogenannten Entwicklungsgeldern aus Ländern des globalen Nordens abhängig. Diese Abhängigkeit führte zu einer massiven Beeinflussung, wenn nicht gar Dominanz, nationaler (Entwicklungs-)Politiken durch die Geberländer und -institutionen (vgl. Sobhan, 1982; Van Schendel, 2009, S. 144ff.). 
aber auch hier positive Erfahrungen mit Transnational Advocacy-Netzwerken vor. Zudem eröffnen grenzüberschreitende gewerkschaftliche Kooperationen die Perspektive für übergreifende zivilgesellschaftliche Bündnisse, die nicht zwangsläufig mit einer Kompromittierung der gewerkschaftlichen Position einhergehen müssen. In diesem Zusammenhang ist ebenso hervorzuheben, dass in der Gewerkschaftslandschaft des Bekleidungssektors Bangladeschs gegenwärtig ein frauenpolitischer Durchbruch zu verzeichnen ist: Erstmals sind mehrere Führungspositionen von Frauen besetzt. Dieser Prozess geht in erster Linie auf das jahrzehntelange frauenbewegte Engagement der Arbeiterinnen und Gewerkschafterinnen zurück, wurde aber zudem von ausländischen Trade Union Support Organisations und (T)NGOs unterstützt. Es liegt folglich eine widersprüchliche und unübersichtliche Ausgangslage bezüglich transnationaler Kooperationen vor, die im Rahmen dieses Beitrags anhand der Frage nach den Chancen und Grenzen von Transnational Social Movement Unionism (TSMU) im Kontext des Bekleidungssektors Bangladeschs erörtert wird.

Vor dem oben skizzierten Hintergrund widerspreche ich der These von Zia Rahman \& Peter Langford (2010), dass SMU auf den Kontext Bangladeschs, und somit auch auf den Bekleidungssektor des Landes, nicht übertragbar sei. Die beiden Autoren kritisieren, dass dem Konzept eurozentrische Annahmen zugrunde lägen. Obgleich diese Kritikperspektive grundsätzlich nachvollziehbar ist, ignorieren Rahman und Langford allerdings ihrerseits nahezu gänzlich die Beschäftigtenstruktur des Bekleidungssektors in Bangladesch: Über 80 Prozent sind Frauen. Angesichts dieses offensichtlich ungleichen Geschlechterverhältnisses und dem weltweit bekannten Problem der unzureichenden Geschlechterdemokratie in Gewerkschaften, dem unter anderem durch SMU begegnet werden soll, ist diese Auslassung nicht nur erstaunlich, sondern vielmehr nachlässig, da sie unwillkürlich zu entsprechenden Leerstellen in der Analyse führt.

Im Gegensatz zu Rahman und Langford argumentiere ich, dass erste Ansätze von TSMU erkennbar sind und das Potenzial dieses Mobilisierungskonzeptes sich am Beispiel des Bekleidungssektors Bangladeschs insbesondere mit Blick auf die Arbeiterinnen und Gewerkschafterinnen offenbart. Ferner wird anhand dieses empirischen Beispiels die transnationale Rahmung des Arbeitsrechtsaktivismus verdeutlicht, der sich vom SMU der 1980er Jahre deutlich unterscheidet und als wegweisende Perspektive zu grenzüberschreitender Kooperation dienen kann. Der Beitrag unterstreicht folglich die Chancen von SMU und verdeutlicht darüber hinaus die Notwendigkeit, sowohl die (selbst-)kritische Perspektive des Ansatzes auf bisherige Forschungsweisen der Labour Studies als auch auf konventionelle gewerkschaftliche Praxen ernst zu nehmen. Andernfalls wird sein (nach wie vor vorhandenes) innovatives Potenzial bezüglich der Wiederbelebung von Gewerkschaften und der Bündelung emanzipatorischer zivilgesellschaftlicher Ressourcen schlicht verspielt. Trotz der Potenziale des Ansatzes treten im Kontext von TSMU in Bangladesch auch Herausforderungen und Ambivalenzen zutage, auf die im Folgenden eingegangen wird.

Der Beitrag basiert auf Empirie, die ich im Rahmen der Arbeiten an meiner Dissertation erhoben habe (Fink, 2018). Während der explorativen Forschungsphase im Jahr 2010 und der Haupterhebungsphase im Jahr 2012, die jeweils in Bangladeschs Hauptstadt Dhaka stattfanden, habe ich insgesamt 47 ExpertInneninterviews mit WissenschaftlerInnen sowie VertreterInnen von Gewerkschaften und NGOs durchgeführt. Im Jahr 2015 fand eine Rückmeldungsphase in Dhaka statt, während der ich die InterviewpartnerInnen an den zent- 
ralen Ergebnissen meines Dissertationsprojekts teilhaben ließ und mich zudem über die Entwicklungen im Anschluss an das Desaster von Rana Plaza informierte (für eine ausführlichere Darstellung der methodischen Vorgehensweise s. Fink, 2018). Bei dem Einsturz des Rana Plazas in Savar, einem Vorort Dhakas, kamen am 24. April 2013 mindestens 1.134 BekleidungsarbeiterInnen ums Leben (das Schicksal von 166 vermissten Personen konnte bis heute nicht abschließend geklärt werden) und 2.535 wurden zum Teil schwer verletzt (vgl. Moazzem \& Islam, 2015). Seitdem steht der Begriff ,Rana Plaza“ nicht nur für die verheerendste Fabrikkatastrophe Bangladeschs, sondern als Synonym für die ausbeuterische Bekleidungsindustrie im globalen Süden.

Der Artikel ist folgendermaßen aufgebaut: Als ersten Schritt erläutere ich mein Verständnis von SMU und rekapituliere Rahman und Langfords Kritik an dem Konzept. Um das schwierige Verhältnis von Gewerkschaften und NGOs in Bangladesch und die hiermit verbundenen Grenzen von TSMU verstehen zu können, folgt ein kurzer Rückblick auf deren Geschichte. Sodann wird auf die Position von Frauen in den Bekleidungsgewerkschaften Bangladeschs eingegangen, um das Potenzial von TSMU anhand ihrer Rolle verdeutlichen zu können. Anhand dieses empirischen Beitrags wird schlussendlich aufgezeigt, inwiefern Forschungen zu SMU von dem analytischen Instrumentarium der Gender Studies, wie z.B. der Intersektionalität, profitieren könnten.

\section{Social Movement Unionism in der Diskussion}

Der Begriff Social Movement Unionism (SMU) ist in den späten 1980er Jahren insbesondere mit Blick auf Länder des globalen Südens entstanden, in denen Gewerkschaften Teil einer breiten gesellschaftlichen Bewegung gegen autoritäre Regierungen waren (vgl. Waterman, 1993). Vor dem Hintergrund von Südafrikas COSATU (Congress of South African Trade Unions) und Brasiliens CUT (Central Única dos Trabalhadores-Unified Workers' Central) entstand die Hoffnung, dass diese Formen der Organisierung den Weg in die gewerkschaftliche Zukunft weisen könnten (vgl. ebd., S. 268). Angesichts der Krise der Gewerkschaften war ein wesentlicher Bestandteil dieser Perspektive, deren Agenda um Anliegen jenseits der Fabriktore zu erweitern, um somit deren gesamtgesellschaftliche Relevanz zu stärken. Vor dem Hintergrund der Geschichte des Scheiterns sozialistischer Projekte sollte die Revitalisierung der ArbeiterInnenbewegung durch neue Konzeptualisierungen von Protest, Widerstand und gesellschaftlichen Visionen erreicht werden, die gemeinsam mit Menschen entworfen werden, die üblicherweise nicht zum klassischen Klientel von Gewerkschaften zählen. Dazu zählen insbesondere die Angehörigen der sogenannten neuen sozialen Bewegungen (z.B. die Queer- und Frauenbewegung, Menschenrechts- und Umweltbewegung), die sich von der , alten“ ArbeiterInnenbewegung abwandten, da sie ihre Interessen dort entweder überhaupt nicht vertreten oder lediglich nachrangig behandelt sahen. Kurzum: Angestrebt wurde eine Demokratisierung und Revitalisierung von ArbeiterInnenbewegung und Gewerkschaften, die insbesondere durch eine Öffnung hin zu den neuen sozialen Bewegungen vonstattengehen sollte (vgl. ebd., S. 266-268). Darüber hinaus ist die explizit internationale Ausrichtung von SMU darauf angelegt, auf die veränderten wirtschaftlichen und politischen Rahmenbedingungen unter den Bedingungen der globalen 
ökonomischen Restrukturierung im Rahmen der neoliberalen Globalisierung adäquat zu reagieren (vgl. Waterman, 1993, S. 245-248).

Die (Watermansche) Definition von SMU offenbart den sowohl empirischen als auch normativen Charakter des Konzeptes. Während COSATU und CUT Ende der 1980er und zu Beginn der 1990er als empirische Referenzen einer neuen Organisierungsform innerhalb eines nationalen Rahmens galten, entsprach der internationalistische Anspruch des Konzeptes mehr einer Vision. Obgleich COSATU und CUT als Beispiele für SMU nunmehr historisch sind und das Konzept als solches von Anbeginn umstritten war (vgl. von Holdt, 2002), ist es nicht ad acta gelegt, sondern dessen Existenz wird angesichts regelmäßig auftretender Koalitionsbildungen zwischen Gewerkschaften und anderen zivilgesellschaftlichen Akteuren, immer wieder aufs Neue geprüft (vgl. bspw. Nowak, 2017; Serdar, 2012; Shlyk, 2009). Gegenwärtig postuliert Jörg Nowak (2017, S. 981) beispielsweise, dass aktuelle Formen von SMU sich vom ,alten' SMU insofern unterscheiden, als dass sie nicht mehr auf der nationalen Ebene auftreten, sondern vielmehr auf der lokalen und regionalen Ebene. Transnationale SMU gäbe es hingegen, so Nowak, äußerst selten (vgl. ebd., S. 983). Vor diesem Hintergrund kritisiert er Ansätze wie Networks of Labour (NOLA) (vgl. Zajak, Egels-Zandén \& Piper, 2017; Zajak, 2017), die versuchen einen neuen Analyserahmen für gegenwärtige Erscheinungsformen transnationaler Kooperation zwischen mehreren verschiedenen Akteuren zu entwickeln, als „,voluntaristisch“ (ebd., S. 983). Jenseits einer Diskussion über die Berechtigung normativer Forschung, die sich hieran entfachen ließ, irritiert an diesem Argument, dass SMU als zentrales Konzept, auf das Nowak rekurriert, selbst einen stark normativen Charakter aufweist. Darüber hinaus kann die Organisierung rund um den Bekleidungssektor Bangladeschs durchaus als Beispiel für einen transnationalen SMU dienen. Transnationale feministische Diskurse schufen hier ab den späten 1980er Jahren den Nährboden für gegenwärtige Solidarisierungen über nationalstaatliche Grenzen hinweg. Vor diesem Hintergrund plädiere ich zum einen für eine stärkere Berücksichtigung von sozialen Strukturkategorien, wie beispielsweise der des Geschlechts, sowie von transnationalen feministischen Diskursen innerhalb der Labour Studies. Zum anderen hinterfrage ich die Notwendigkeit einer geographischen Lokalisierung des gegenwärtigen SMU. Ist solch eine Festschreibung überhaupt möglich und falls ja, welchen analytischen Mehrwert hätten wir hiervon? Gewinnbringender erscheint mir vielmehr eine kontextsensible Analyse seiner jeweiligen Erscheinungsformen. Zentral ist hierbei jedoch gewiss - wie von Waterman intendiert -, eine große Wachsamkeit gegenüber Organisierungsformen jenseits des traditionellen gewerkschaftlichen Musters. Dieses bedeutet zweifellos, dass das zuweilen 'konservative' analytische Repertoire der Labour Studies einer Diversifizierung bedarf, was unter anderem auch anhand der Begriffsgeschichte des SMU-Konzeptes ersichtlich ist.

SMU ist seit seiner Entstehung in den späten 1980er Jahren Gegenstand vielfältiger Aneignungen und Umdeutungen geworden, was letztlich dazu führte, dass SMU zwar in aller Munde ist, jedoch selten dasselbe damit gemeint ist (vgl. Scipes, 2014). Der kleinste gemeinsame Nenner aller gegenwärtigen Interpretationen von SMU ist wohl, dass das Konzept den Versuch darstellt, auf die Krise der Gewerkschaften mit einer Öffnung hin zu den neuen sozialen Bewegungen zu reagieren (vgl. Waterman, 1993). Jenseits dieser Minimaldefinition ist jedoch beispielsweise umstritten, welche Rollen den unterschiedlichen Akteuren innerhalb von SMU zukommen. Scipes (2014) unterscheidet diesbezüglich zwischen 
der seiner Ansicht nach verkürzten nordamerikanischen Rezeption im Anschluss an Kim Moody sowie der Ausrichtung, die sich in der Tradition von Peter Watermans Konzeptualisierung verortet. Während erstere eine avantgardistische Rolle des Proletariats vorsieht, versteht letztere die neuen sozialen Bewegungen und die ArbeiterInnenbewegung als gleichberechtigt. Die Adaption von Moody (1997) von SMU beraubt den Ansatz folglich seines kritischen Impetus, in dem abermals eine Hierarchie zwischen den verschiedenen Bewegungen hergestellt wird. Demgegenüber knüpft mein Verständnis von SMU an Waterman an, jedoch verwende ich dennoch im Folgenden die Bezeichnung Transnational Social Movement Unionism (TSMU) statt den durch Waterman zuletzt verwendeten Begriff des NISU (New International Social Unionism) (vgl. Waterman, 2004). Zum einen, da die Bezeichnung, transnational' meiner Perspektive nach sowohl die Distanz zu früheren Internationalismen orthodox marxistischer Prägung deutlich macht, als auch die Wortpaarung von Transnational Social Movement den zivilgesellschaftlichen und bewegungsorientierten Fokus adäquater reflektiert. Zudem soll durch diese begriffliche Distanzierung deutlich werden, dass mein Verständnis von TSMU im Gegensatz zu Watermans weniger utopischvisionären Charakter hat. Waterman, der im Jahr 2017 verstarb, verwehrte sich zuletzt generell gegenüber einer empirischen Verwendung von SMU und bezeichnete bloße Allianzen zwischen Gewerkschaften und sozialen Bewegungen nicht als SMU, sondern imaginierte vielmehr deren Synthese (vgl. Waterman, 2004). Hiervon abweichend erkenne ich fruchtbare Allianzen zwischen diesen beiden Organisations- bzw. Bewegungsformen durchaus als SMU an. Kurzum: Ich verstehe TSMU als eine Mobilisierungsstrategie, die (transnationale) Allianzen zwischen Gewerkschaften und sozialen Bewegungen vorsieht. Die sozialen Bewegungen werden hierbei häufig in der institutionalisierten Form einer NGO repräsentiert. Das Ziel dieser Allianzen ist ein Prozess der Demokratisierung und (Re-) Vitalisierung von Gewerkschaften, der mit einer breiteren und nachhaltigeren Organisierung von Beschäftigten einhergeht.

In Watermans Definition von SMU ist ersichtlich, dass Forderungen der Frauenbewegung inkorporiert wurden. Fernab eines Business Unionism reichen die im Rahmen von SMU formulierten Ziele klar über den Arbeitsplatz hinaus. So gehört beispielsweise die gerechte Verteilung von Hausarbeit zwischen den Geschlechtern ebenso wie die Bekämpfung von Sexismus und Rassismus am Arbeitsplatz, in Gewerkschaften und hierüber hinaus, zu den Zielen von SMU (vgl. Waterman, 1993, S. 266). Nichtsdestotrotz zeichnet sich die übrige SMU- und Gewerkschaftserneuerungs-Literatur eher durch eine geringe Berücksichtigung der Kategorie Geschlecht aus. Ebenso nehmen Fragen der Gewerkschaftserneuerung in den Gender Studies eher eine randständige Position ein. In einem sehr lesenswerten Artikel geht Jan Kainer (2009) der Frage nach, warum zwischen der Gewerkschaftserneuerungs-Literatur und den Gender Studies bisher nur wenige Berührungspunkte existieren. Insbesondere die nichtvorhandene Resonanz aus den Gender Studies führt sie darauf zurück, dass die Idee von SMU für Frauen in Gewerkschaften alles andere als neu ist, sondern vielmehr von ihnen seit jeher praktiziert wird. Schließlich sind es, so Kainers Argument, insbesondere die frauenbewegten Gewerkschafterinnen, die versuch(t)en, Gewerkschaften für die Anliegen von Frauen, die bspw. auch über die Lohnarbeit hinausreichen, zu sensibilisieren und selbige unter anderem hierüber zu demokratisieren. Teil dieses Demokratisierungsprozesses war, analog zu gleichzeitig stattfindenden entsprechenden Entwicklungen in 
den Frauenbewegungen, den singulären Fokus auf (weiße Mittelschichts-)Frauen auszuweiten und die gesellschaftliche Wirkungsmacht von sozialen Kategorien wie ,Rasse', Migration, Behinderung und sexueller Orientierung ernst zu nehmen (vgl. Kainer, 2009, S. 26). Ein hierfür bevorzugtes Mittel war spätestens seit den 1970er Jahren, auf nationaler wie transnationaler Ebene, die Bildung von Koalitionen mit Bewegungsorganisationen und NGOs. Jenes Engagement sei bisher allerdings vom überwiegend männlichen Mainstream der Gewerkschaftserneuerungs-Literatur nicht entsprechend gewürdigt worden und folglich erscheine die Koalitionsbildung mit anderen zivilgesellschaftlichen Akteuren hier als ,innovative und neue' Idee (2009, S. 32). Ebenso macht Alicia Schmidt Camacho (1999) in einem Rückblick auf die Gewerkschaftsgeschichte der USA darauf aufmerksam, dass es in erster Linie die Angehörigen der Bürgerrechtsbewegung waren, die den begrenzten Wirkungsbereich des Business Unionism entlarvten. Folglich stellte SMU für gewerkschaftlich engagierte People of Colour (PoC) in den USA häufig die einzige Möglichkeit dar, um ihren Anliegen über das Vehikel der Bürgerrechtsbewegung Gehör zu verschaffen und in die Gewerkschaften hineintragen zu können (Schmidt Camacho, 1999, S. 94). Die Kritik lautet folglich, dass die Begründer von SMU die Etablierung eines vermeintlich neuen Ansatzes für sich reklamierten, den Feministinnen und $\mathrm{PoC}$ längst praktizierten. Hiermit ging einher, dass das Potenzial einer beispielsweise geschlechtersensiblen SMU-Perspektive für Mobilisierung und Organisierung lange schlicht nicht gesehen wurde, was wiederum zu der Krise der Gewerkschaften beitrug. Diese problematische Ausgangssituation findet sich auch in Bangladesch. Wie eingangs erwähnt, wurde die Frage der Übertragbarkeit von SMU auf den Kontext Bangladesch, bisher nur von Rahman und Langford diskutiert, die hierauf eine abschlägige Antwort geben. Sie kritisieren, dass SMU ein eurozentrisches Modell sei, das den durch Kolonialismus und Imperialismus geprägten Kulturen der industriellen Beziehungen in Ländern des globalen Südens nicht gerecht werde. Im Einzelnen lauten ihre zentralen zwei Kritikpunkte, dass erstens weder Gewerkschaften noch NGOs in Bangladesch ihre Existenz ohne die Unterstützung Dritter absichern können und ihre Autonomie, die als Voraussetzung einer Allianzbildung auf Augenhöhe im Rahmen von SMU gilt, daher nicht gegeben sei (vgl. Rahman \& Langford, 2010, S. 55). Die beiden Autoren postulieren zweitens, dass SMU einen Mittelschichts-Bias aufweise, und somit der durch Imperialismus, Kolonialismus und Neoliberalismus herbeigeführten brutalen Lebensrealität in Ländern des globalen Südens nichts Wirksames entgegenzusetzen habe. Initiativen der Gewerkschaftserneuerung dürften sich daher, so die Autoren weiter, einzig auf die Bekämpfung von transnationalen Unternehmen, den kapitalistischen Kernländern, und ihren supranationalen Verbündeten konzentrieren (vgl. ebd., S. 59).

Der erstgenannte Kritikpunkt von Rahman und Langford trifft den Kern der schwierigen Voraussetzungen für SMU in Bangladesch und wird im Folgenden eingehender diskutiert. Der zweite Punkt wiederum ist eine etwas verklausuliert formulierte Wiederauflage des Haupt- und Nebenwiderspruchsargument, das die Anliegen der neuen sozialen Bewegungen, so auch der Frauenbewegung, durch den Verweis auf deren vermeintliche Nachrangigkeit zu diskreditieren versucht. An dieser Stelle tritt das große Beharrungsvermögen innerhalb der Labour Studies zutage, unter dessen Vorzeichen SMU weniger einer tatsächlichen Öffnung hin zu sozialen Bewegungen, als vielmehr deren Subsumtion entspricht. Im Rahmen dieses Artikels wird hingegen aufgezeigt, wie erst durch die gezielte Adressierung 
des vermeintlichen Nebenwiderspruchs des ungleichen Geschlechterverhältnisses, Organisierungspotenziale aufgezeigt werden können, die einen breiten und nachhaltigen Widerstand gegen ausbeuterische Arbeitsverhältnisse ermöglichen. Über die Rehabilitierung der Idee von SMU für den Kontext Bangladeschs hinaus, besteht das Anliegen dieses Artikels folglich darin, den zentralen Stellenwert der Berücksichtigung der spezifischen Verortung der Beschäftigten für Mobilisierungs- und Organisierungspraxen zu unterstreichen. Mit Blick auf die Bekleidungsindustrie Bangladeschs bedeutet dies, nicht nur den sozialen Platzanweisern der Klasse und geographischen Lokalität, sondern zumindest ebenso der Kategorie Geschlecht einen angemessenen Platz in der Analyse einzuräumen. Letztlich kann so zudem verdeutlicht werden, inwiefern die Labour Studies von der Perspektive der Gender Studies profitieren könnten, in der die Bedeutung unterschiedlicher Strukturkategorien im Hinblick auf die Analyse von Macht- und Herrschaftsverhältnissen spätestens seit der Debatte um das Paradigma der Intersektionalität prominent diskutiert wird. Das Charakteristikum dieses Forschungsparadigmas besteht im Gegensatz zu einer additiven Analyse mehrerer Kategorien vielmehr in der Untersuchung ihrer Wechselwirkungen. Angestrebt wird hierbei die Wechselwirkungen dieser Kategorien auf sowohl der Mikro-, Meso-, als auch Makroebene zu untersuchen (vgl. Crenshaw, 1991; Lutz, Herrera Vivar \& Supik, 2010). Wird diese Perspektive auf den Bekleidungssektor Bangladeschs in seiner transnationalen Verwobenheit angelegt, kann m.E. folgende These im Hinblick auf Strategien kollektiver Aktion formuliert werden: Während die Verortung der Beschäftigten einerseits Mobilisierung aufgrund des hohen Grades der Ausbeutung, des desolaten Zustandes der Gewerkschaften sowie ihrer männlichen Dominanz erschwert, eröffnen andererseits (trans-) nationale zivilgesellschaftliche Diskurse Gelegenheitsfenster zur Organisierung (vgl. Fink, 2018).

\section{Zivilgesellschaft und NGOs in Bangladesch}

Neben der Unabhängigkeitsbewegung als zentrale (historische) zivilgesellschaftliche Größe des Landes weist Bangladesch eine lange karitative Tradition auf (vgl. Lewis, 2011). Naturkatastrophen und Hungersnöte sowie der Unabhängigkeitskrieg mit seinen vielen Opfern und Geschädigten trugen in Anknüpfung an diese Tradition letztlich zur Etablierung des modernen NGO-Sektors bei. Im Rahmen der Aid-Dependency und entwicklungspolitischen Lösungen wie Good Governance hatten an der Errichtung dieses Sektors internationale Entwicklungsorganisationen und ausländische NGOs einen großen Anteil. Somit entstand eine neue Generation von ,Entwicklungs-NGOs' und der NGO-Sektor erfuhr ab den 1990er Jahren einen regelrechten Boom (vgl. Karim, 2001). Obgleich anfangs viele NGOs an Zielen der sozialen Mobilisierung orientiert waren, gaben die meisten jedoch diesen Anspruch - bedingt durch rechtliche Einschränkungen, Vorgaben (transnationaler) Geldgeber oder die Furcht vor der Verärgerung mächtiger Akteure - im Laufe der Zeit auf und konzentrierten sich vollends auf die Vergabe von Mikrokrediten (vgl. Karim, 2016; Kabeer \& Haq Kabir, 2009; Feldman, 2003; Stiles, 2002). Darüber hinaus wird konstatiert, dass NGOs durch den Prozess der Institutionalisierung und Transnationalisierung zu einer allgemeinen Depolitisierung der Zivilgesellschaft beigetragen haben. Die Denkschule des „Developmen- 
talism“ (van Schendel, 1995, zitiert nach White, 1999, S. 325) habe so weit um sich gegriffen, dass beispielsweise Armut nur mehr als technisches Problem verstanden werde, dem es durch entsprechende ,Projekte' oder den Zugang zu Mikrokrediten zu begegnen gelte. Fragen der gesellschaftlichen Machtverhältnisse würden somit ausgeklammert. Den Beschäftigten der NGOs, die zumeist der oberen Mittelklasse angehören und internationale Ausbildungen genossen haben, wird zudem vorgeworfen, mit ihrer Arbeit in erster Linie den eigenen sozialen Statuserhalt zu verfolgen. Im Kontrast zu ihrem international überwiegend positiven Image werden NGOs in Bangladesch folglich in erster Linie als eigennützige Organisationen gesehen, die das Los der armen Bevölkerung als ,Business-Idee ' für das eigene Fortkommen instrumentalisieren (vgl. Lewis, 2011, S. 125). Zusätzlich zu diesem ohnehin miserablen Ruf von NGOs, kommt innerhalb der Gewerkschaftsszene überdies erschwerend hinzu, dass das US-amerikanische Solidarity Center ${ }^{3}$ im Bekleidungssektor lange Zeit die einzig aktive NGO darstellte. Das imperialistische Erbe des Solidarity Centers und sein teils konkurrierendes sowie überhebliches Auftreten gegenüber den Gewerkschaften Bangladeschs, nährten vielmehr bereits existierende bangladeschische Narrative des Imperialismus und der Verschwörung, anstatt selbige zu entkräften (vgl. Rahman \& Langford, 2014). Andere im Bekleidungssektor aktive (T)NGOs werden von den Gewerkschaften als Konkurrenz wahrgenommen. Die (T)NGOs würden sich zwar in karitativer Absicht den ArbeiterInnen zuwenden, etablierten aber hierdurch, so die zentrale Kritik, eine Servicementalität, durch die sie die Beschäftigten von den Gewerkschaften entfremden (vgl. Fink, 2014). Vor diesem Hintergrund meidet ein großer Teil der Gewerkschaften NGOs und betrachtet deren Engagement im Bekleidungssektor äußerst kritisch. Die Gewerkschaften Bangladeschs können wiederum ihrerseits mit keinem guten Image aufwarten.

\section{Gewerkschaften in der Bekleidungsindustrie}

Bangladeschs Gewerkschaften haben sektorenübergreifend folgende zentrale Probleme: Eine starke Anbindung an politische Parteien; einen hohen Grad der Fragmentierung der Gewerkschaftslandschaft; eine sehr geringe Organisierungs- und Unterstützungsbasis; die Arbeiterferne der Gewerkschaftsfunktionäre; ein Strategie- und Kompetenzdefizit; Korruption sowie die geringe Repräsentation von Frauen (vgl. Faruque, 2009; Badruddin, 2004; Dan-

3 Das Solidarity Center (SC), dessen offizielle Bezeichnung American Center for International Labor Solidarity (ACILS) lautet, ist eine ,Quasi-NGO‘, die durch den US-amerikanischen Gewerkschaftsdachverband AFL-CIO (American Federation of Labor and Congress of Industrial Organizations) ins Leben gerufen wurde. Das SC ist dafür bekannt, während des Kalten Krieges in den jeweiligen Länderbüros die außenpolitischen Interessen der US-Regierung vertreten zu haben und wurde dafür wiederholt des Gewerkschaftsimperialismus bezichtigt (vgl. Scipes, 2012). Seinen Etat bestreitet das SC zu 95 Prozent aus Regierungsmitteln, die über die entwicklungspolitische Ausführorganisation USAID (United States Agency for International Development) sowie die durch den Kongress finanzierte Stiftung NED (National Endowment for Democracy) an das SC ausgezahlt werden (vgl. Bass, 2012, S. 104). Die Bezeichnung NGO ist daher fraglich. In Bangladesch ist das SC seit Jahrzehnten sehr aktiv, gehörte zu den ersten (ausländischen) zivilgesellschaftlichen Akteuren im Bekleidungssektor und trug unter anderem wesentlich dazu bei, eine Gewerkschaft namens BIGUF (Bangladesh Independent Garment Workers Union Federation) zu gründen. BIGUF entstand auf Initiative von vier ehemaligen Arbeiterinnen und zeichnete sich von Anbeginn durch einen hohen frauenpolitischen Anspruch aus (vgl. bspw. Dannecker, 2002). 
necker, 2000). All diese Defizite finden sich auch in den Gewerkschaften des Bekleidungssektors wieder, die hierin kaum präsent sind. So wurde 2009 auf Basis einer Befragung geschätzt, dass in lediglich 120 von damals insgesamt 4.500 Fabriken eine Betriebsgewerkschaft existiert (vgl. Faruque, 2009, S. 24). Der Organisierungsgrad war somit mit weniger als 5 Prozent verschwindend gering. Zwar ist im Anschluss an Rana Plaza eine vergleichsweise hohe Zahl an Neuregistrierungen von Gewerkschaften zu verzeichnen, die bis zum Frühjahr 2017 auf 571 angestiegen ist (vgl. Hossain Ovi, 2017). Es wird jedoch vermutet, dass unter anderem aufgrund der nach wie vor existierenden starken Repression durch das Fabrikmanagement nur ein Bruchteil dieser Gewerkschaften tatsächlich aktiv ist (vgl. ebd.). Überdies wäre auch ein Verhältnis von insgesamt circa 570 aktiven Betriebsgewerkschaften zu gegenwärtig knapp 4.500 Bekleidungsfabriken (vgl. BGMEA, 2017) nach wie vor sehr gering. Dies bedeutet, dass selbst mehrere Jahre nach dem Einsturz von Rana Plaza, das auf dramatische Weise die Konsequenzen des Fehlens einer Arbeitnehmervertretung deutlich gemacht hat ${ }^{4}$, keine bedeutenden Erfolge in Bezug auf die Realisierung der Vereinigungsfreiheit zu verzeichnen sind. De facto sind Gewerkschaften innerhalb der Produktionsstätten also nach wie vor kaum präsent. Hieran hat bisher auch der Bangladesh Accord on Fire and Building Safety nichts Wesentliches ändern können, der unter dem Eindruck von Rana Plaza zwar in erster Linie auf Gebäudesicherheit abzielt, aber von globalen Gewerkschaften entworfen wurde und durchaus das Ziel der Involvierung und Stärkung von Gewerkschaften formuliert (vgl. Zajak, 2017; Anner, 2015).

Die von mir interviewten GewerkschafterInnen begrüßen die Unterstützung seitens transnationaler Advocacy-Netzwerke, wie beispielsweise der Clean Clothes Campaign deutlich. Ebenso sehen Sie einen großen Bedarf hinsichtlich von Capacity Building-Maßnahmen durch beispielsweise (T)NGOs. Jegliches weiteres Engagement dieser Akteure im Sektor betrachtet die Mehrheit vor dem Hintergrund der oben erläuterten Erfahrungen jedoch kritisch. Nichtsdestotrotz gehen manche Gewerkschaften unter anderem vor dem Hintergrund ihrer schwierigen finanziellen Lage Kooperationen mit (T)NGOs ein. Aufgrund des ohnehin geringen Organisierungsgrades und der unregelmäßigen Zahlung von Mitgliedsbeiträgen ist die finanzielle Situation der Gewerkschaften äußerst prekär. Ohne externe Unterstützungsgelder, wie beispielsweise Spenden, Zuwendungen von nahestehenden Parteien oder auch Projekte mit NGOs könnte die Arbeit kaum aufrechterhalten werden.

Zusammenfassend muss bezüglich der Situation von NGOs und Gewerkschaften in Bangladesch folglich festgehalten werden, dass die Bedingungen für die Realisierung von SMU schwierig sind: Erstens fallen NGOs, denen im normativen Modell von SMU die Rolle der politischen Impulsgeber zukommt, vielmehr mehrheitlich durch ihren apolitischen Charakter auf. Zweitens sind weder NGOs noch Gewerkschaften, wie von Rahman und Langford (2010) diagnostiziert, in dem Maße autonom, als sie beispielsweise Entscheidungen zu etwaigen Bündnisbildungen ohne die Rücksichtnahme auf ihre jeweiligen Unterstützer fällen könnten. Vor diesem Hintergrund ist drittens das Verhältnis zwischen NGOs und Gewerkschaften vielfach durch Argwohn und Konkurrenz gekennzeichnet. Nichtsdestotrotz

4 Am Tag vor dem Einsturz bemerkten die Beschäftigten große Risse im Gebäude und evakuierten es. Am folgenden Tag wurden sie von den Fabrikbesitzern unter Androhung des Entzugs ihres Monatslohns dazu genötigt, wieder ihre Arbeit im Gebäude aufzunehmen. In den Fabriken gab es keine Gewerkschaft, die auf das Recht auf einen sicheren Arbeitsplatz hätte pochen können. 
existieren aber vereinzelt, wie im folgenden Abschnitt aufgezeigt wird, Allianzen zwischen diesen Organisationsformen, die deutliche Schnittstellen mit dem Modell von SMU aufweisen.

\section{Frauen in den Bekleidungsgewerkschaften Bangladeschs}

Während Frauen in den 1990er Jahren in den Bekleidungsgewerkschaften kaum aktiv waren und keine Führungspositionen einnahmen (vgl. Dannecker, 2000, S. 34) entspricht dies gegenwärtig nicht mehr dem Status quo. Obgleich die Repräsentation von Frauen in Gewerkschaften nach wie vor gering ist (vgl. BILS, 2009, S. 8), wird seit einigen Jahren von einer neuen Generation innerhalb der Gewerkschaftsszene des Bekleidungssektors gesprochen. Diese Generation zeichnet sich dadurch aus, dass sie weiblich und parteipolitisch unabhängig ist sowie, im Gegensatz zu ihrer Vorgängergeneration der studierten männlichen Berufsgewerkschafter, vor ihrer gewerkschaftlichen Laufbahn selbst als Arbeiterinnen tätig war. Darüber hinaus steht diese Generation mehrheitlich mit ausländischen Labour Support-Organisationen und transnational agierenden Akteuren in Kontakt. Somit kann festgehalten werden, dass die Transnationalisierung und Feminisierung von Gewerkschaftsarbeit in einem deutlichen Zusammenhang steht. Gewerkschafterinnen, die sich in ihrer Rolle diskriminiert sehen, identifizieren in der transnationalen Unterstützung zum einen die Möglichkeit, frauenspezifische Angebote für Arbeiterinnen anzubieten und zum anderen ihrem marginalen Status innerhalb der Gewerkschaftsbewegung etwas entgegenzusetzen. Ausländische zivilgesellschaftliche Organisationen wiederum unterstützen insbesondere Gewerkschafterinnen, um sie in ihrem Kampf für mehr Geschlechterdemokratie innerhalb der Gewerkschaftsszene zu unterstützen. (Trans-)nationale zivilgesellschaftliche Diskurse der Frauenemanzipation und Geschlechterdemokratie eröffnen somit Gelegenheitsfenster zur Organisierung (vgl. Fink, 2018). Dass Kontakte mit transnationalen Akteuren jedoch keine zwingende Voraussetzung für eine gewerkschaftliche Laufbahn sind, ist ebenso zu konstatieren. Während der Erhebungsphase meiner Dissertation (2010-2015) stellten Frauen in fünf Bekleidungsföderationen das Amt der Vorsitzenden und ich hatte die Gelegenheit mit weiteren zehn Gewerkschafterinnen zu sprechen, die jeweils andere zentrale Führungsaufgaben, wie etwa die der stellvertretenden Vorsitzenden, in ihren Föderationen einnahmen. Fünf dieser Gewerkschafterinnen entwickelten ihre gewerkschaftliche Laufbahn in engem Kontakt mit transnationalen Organisationen. Die übrigen zehn wiesen zumindest anfänglich keinerlei derartige Verbindungen auf, was sich jedoch änderte, nachdem sie Positionen in Föderationen innehatten. Einige von ihnen nahmen an den Trainings- und Vernetzungskursen der bangladeschischen NGO INCIDIN (Integrated Community and Industrial Development Initiative) teil, die folglich in der Berufsbiographie dieser Gewerkschafterinnen jeweils besondere Erwähnung fand. INCIDIN versteht sich als bewegungsnahe Organisation und bietet seit 2002 ein Qualifizierungs- und Vernetzungsprogramm für weibliche Gewerkschaftsvorsitzende an. Dieses Programm wurde anfänglich durch die TNGO Oxfam im Rahmen der Kampagne Make Trade Fair unterstützt, die unter anderem auf die Verbesserung der Arbeitsrechtssituation von weiblichen Beschäftigten am südlichen Ende transnationaler Wertschöpfungsketten abzielt. Über das Angebot an die weiblichen Gewerkschafts- 
vorsitzenden hinaus, waren breit angelegte Capacity Building-Maßnahmen für insgesamt 22 Gewerkschaftsföderationen Bestandteil des Programms von INCIDIN, die mithilfe von Gender Mainstreaming-Komponenten, die Rolle von Frauen in Gewerkschaften nachhaltig stärken sollten. Gegenstand der Fortbildungen für die weiblichen Gewerkschaftsvorsitzenden waren Computerkurse sowie Schulungen über Öffentlichkeitsarbeit und das Arbeitsrecht. Das Ziel des Projektes beschränkte sich aber nicht auf die bloße Wissensvermittlung, sondern sollte ebenso einen Raum zur Vernetzung und zum Dialog bieten, um so zum einen der Fragmentierung der Gewerkschaftsszene entgegenzuwirken und zum anderen einen strategischen Austausch zwischen weiblichen Gewerkschaftsvorsitzenden zu ermöglichen. INCIDIN zielt zudem darauf $a b$, insbesondere Gewerkschafterinnen über die Grenzen von Bangladesch hinaus zu vernetzen und Koalitionen mit anderen Gewerkschaften und zivilgesellschaftlichen (Bewegungs-)Akteuren zu ermöglichen. Hierzu diente beispielsweise eine gemeinsame Reise von INCIDIN-MitarbeiterInnen und Gewerkschafterinnen zum vierten Weltsozialforum nach Mumbai im Jahr 2004. Ebenso konnte INCIDIN in der Vergangenheit Kontakte mit globalen und ausländischen Gewerkschaften, Stiftungen und JournalistInnen herstellen, die jeweils zu Einladungen der Gewerkschafterinnen in diverse Länder Europas und Asiens geführt haben.

Das Engagement von INCIDIN erfährt seitens der Gewerkschaften einhellige Zustimmung. Die von mir interviewten Gewerkschafterinnen betonen die Wichtigkeit des Dreiklangs von Qualifizierung, Vernetzung über Gewerkschaftsgrenzen hinweg und internationalem Austausch, von dem sie ihrer Aussage nach sehr profitieren. INCIDIN sticht folglich als positives Beispiel unter den übrigen im Bekleidungssektor aktiven (T)NGOs heraus. Obgleich die Kooperation von INCIDIN mit den Gewerkschaften eindeutig durch eine Unterstützungsleistung seitens der NGO gekennzeichnet ist und damit nicht dem Idealbild einer gleichberechtigten Partnerschaft im Sinne von SMU entspricht, sind doch andere zentrale Charakteristika des Konzepts erkennbar. Insbesondere sind hierbei der Versuch der geschlechterpolitischen Demokratisierung der Gewerkschaften sowie die Vernetzung über Gewerkschaftsgrenzen und nationale Grenzen hinaus zu nennen. Diesem Fokus in INCIDINs Arbeit geht die Einsicht voraus, dass insbesondere Gewerkschafterinnen zur Vitalisierung der Gewerkschaften beitragen können. Um im Einzelnen zu illustrieren, welche Impulse zur Gewerkschaftserneuerung von Frauen ausgehen, die im Rahmen von Koalitionen mit NGOs wie INCIDIN idealerweise positiv verstärkt werden könnten, wird im Folgenden ein Blick darauf geworfen, was die Gewerkschafterinnen dazu motiviert, sowie welche Organisierungsformen und Strategien sie anwenden, um sich innerhalb der männlich dominierten Gewerkschaften durchzusetzen.

\section{Organisierungsformen, Motivation und Strategien}

Die favorisierte Organisierungsform meiner Interviewpartnerinnen stellt die separate Organisierungsstrategie dar. Darüber hinaus organisieren sie sich vereinzelt auch außerhalb von Gewerkschaften. Unter ersterem ist eine Organisierung in separaten Strukturen innerhalb von bestehenden Gewerkschaften, wie beispielsweise der Etablierung von Frauenkomitees, zu verstehen (vgl. Broadbent \& Ford, 2008, S. 5), was zweifelsohne die gängigste Organisierungsstrategie von Frauen in Bangladeschs Bekleidungssektor darstellt (vgl. BILS, 2009, S. 13). Eine Organisierung außerhalb von Gewerkschaften ist etwa ein Engagement im 
Rahmen von (Frauen-)Arbeitsrechts-NGOs, die bestehenden Gewerkschaften insbesondere aufgrund ihrer männlichen Dominanz vorgezogen wird (vgl. ebd., S. 7). Diese Organisierungsform wird jedoch äußerst ambivalent betrachtet, was anhand des beruflichen Werdegangs von Uma Nilanjan ${ }^{5}$ anschaulich verdeutlicht werden kann. Nilanjan wandte sich zunächst frustriert von einer Gewerkschaft ab, um in einer Frauen-NGO zu arbeiten, die Arbeit dieser Organisation jedoch ebenso als defizitär erachtete und daher ihre eigene FrauenNGO gründete. Ihre Beweggründe schildert sie folgendermaßen:

"While working for the trade union I realized, that I can't help the girls and women properly because as a
trade unionist I am not supposed to interfere in family matters. The law doesn't allow this and my colleagues
in the trade union didn't support this either. But some of the girls have very problematic family matters,
which need to be solved. (...) I was also unhappy in the trade union because of our position as women in the
union and our rights, we felt so dwarfish there. We didn't get what we deserve [lacht]. Then I learned about
the work of NGOs, which work for women's empowerment and because I was so unhappy in the federation I
decided to work for a NGO. There I worked with distressed women and after having worked there for a
while, I noticed that the NGO actually gives up before they achieve the target, which they settled. For exam-
ple, if I want to achieve women's empowerment, I need to empower women to a certain level. But before the
NGO gained that, they gave up. They gave up because the project duration was limited to a certain period of
time. But women's empowerment isn't done in one year, you cannot simply stop after some time, it's a con-
tinuing process. That is actually the main difference between trade unions and NGOs. The trade union works
continuously, the NGO doesn't. But unfortunately, trade unions don't focus enough on women's empower-
ment."

Aus diesem Zitat geht unmissverständlich hervor, dass Nilanjan die Organisierung innerhalb einer Gewerkschaft im Grunde vorzieht, da ihr die fehlende Nachhaltigkeit sowie der marktförmige Projektcharakter in der Arbeit von NGOs insbesondere aus feministischer Perspektive widerstrebt. Gleichzeitig ist in ihrer Aussage ebenso die Ambivalenz gegenüber Gewerkschaften erkennbar, in deren Arbeit sie zwar die nötige Nachhaltigkeit sieht, jedoch programmatische Defizite identifiziert. Während die NGO sich der Lebens- und Arbeitssituationen von Frauen zwar zeitlich begrenzt aber dennoch in einer ganzheitlichen Perspektive widme, zeichne sich die Gewerkschaft durch eine mehrheitliche Ignoranz gegenüber den spezifischen Anliegen von weiblichen Beschäftigten aus. Diese Position Nilanjans steht beispielhaft für sowohl die Ambivalenz von Feministinnen gegenüber diesen beiden Organisationsformen als auch die kritische Reflexion des eigenen Engagements, die weltweit zu teils dilemmatischen Suchbewegungen nach der jeweils geeigneten Organisierungsform führt (vgl. bspw. Britwurm, Douglas \& Ledwith, 2012; Alvarez, 1999, 2009; Broadbent \& Ford, 2008). Obgleich sich vor diesem Hintergrund die Mehrheit der frauenbewegten bangladeschischen Gewerkschafterinnen dennoch für ein Engagement in einer Gewerkschaft entschied, zog Nilanjan es aufgrund der in der obigen Interviewpassage angesprochenen Missachtung von Frauen in Gewerkschaften vor, eine Frauen-NGO zu gründen. Der wesentliche Schlüsselmoment in ihrem Entscheidungsprozess war die Erinnerung an ihr Vorbild Mamata Banerjee, die im indischen Westbengalen Parteivorsitzende der Partei All India Trinamool Congress ist. Uma Nilanjan hofft, als Vorsitzende einer NGO diese Vorbildfunktion nun für jene Frauen, für die sie sich engagiert, einnehmen zu können. Dass weibliche Vorbilder in der Motivation und Arbeit der Gewerkschafterinnen eine große Rolle spielen, ist aus mehreren Interviews hervorgegangen. Zum Beispiel dienen die Vorbilder

5 Sämtliche Namen meiner Interviewpartnerinnen sind Pseudonyme. 
ebenso zur Untermauerung der eigenen politischen Haltung. Die Gewerkschafterin Tamina Robin reagiert beispielsweise auf den Versuch einiger ihrer Gewerkschaftskollegen, Arbeiterinnen über die Zuschreibung eines Sex-Arbeiterinnenstatus zu diskreditieren, mit folgender an Rosa Luxemburg angelehnten Argumentation:

"Some male trade union leaders, very few but some, said: 'Tamina-Apa ${ }^{6}$, lots of sex workers are working in the garment factories'. But our attitude is that sex workers are very exploited women of the society. Rosa Luxemburg was working a lot for them. She published a journal for sex workers. So our attitude is not that sex workers are bad or something like that. I think our attitude is completely different, our values are completely different."

Über den hohen Stellenwert von Vorbildern hinaus, erwähnen alle Gewerkschafterinnen den Zuspruch der Arbeiterinnen als zentrale Motivationsquelle für ihre Arbeit. Sämtliche Gewerkschafterinnen berichteten, dass sich Arbeiterinnen ihnen gegenüber - im Gegensatz zu ihren männlichen Kollegen - erstmals öffnen konnten und nur über sie den Zugang zu Gewerkschaften fanden. Dieser große Zuspruch bekräftigt die Gewerkschafterinnen darin, ihre Position, trotz der Diskriminierung innerhalb der Gewerkschaften, zu behaupten. Anika Begum war hierdurch sogar dazu motiviert, sich gegen den Widerstand ihres Ehemanns durchzusetzen, der ebenso in ihrer Gewerkschaft tätig ist:

"I was fighting and I never gave up [lacht]. In fact, I told my husband as his wife, as his relative, I always told him that he could leave anytime, that he could quit. Because the simple fact is that the workers want me."

Der große Zuspruch der Arbeiterinnen half Anika Begum letztlich auch dabei, sich einerseits gesellschaftlichen Restriktionen zu widersetzen, aber andererseits ebenso die sich widersprechenden gesellschaftlichen Rollenerwartungen, die an sie als Ehefrau und Gewerkschaftsfunktionärin herangetragen werden, zu versöhnen:

"There were several problems with my husband. We are husband and wife and in our country there are a lot
of prejudices. Initially, when I wanted to run for president, he was against it and he asked me: 'What will the
others say? What will they say if you are the president but I'm not? So I developed a logic for him and my-
self: Whenever I gave a speech at a rally I didn't do that as his wife. I told him that I will go there as a lady,
as a normal person, as a labour leader. And I will do all other related tasks on my own. I told him that I
wouldn't act as his wife. It was very good that the workers wanted me. This way, my husband was finally
forced to let me do my work."

In den obigen Zitaten klingt bereits an, dass die Gewerkschafterinnen den großen Zuspruch, den sie erfahren, auf die Tatsache zurückführen, dass sie Frauen sind und auf die Arbeiterinnen daher besser eingehen könnten. In der folgenden Interviewpassage wird nunmehr explizit benannt, dass die Gewerkschafterinnen sich insbesondere durch ihr Geschlecht und ihre hiermit zusammenhängende Sensibilität für die Anliegen der weiblichen Beschäftigten, zu ihrer Tätigkeit berufen fühlen:

"Actually, only very few of the federation leaders are female, most of them are male. But we, [Aufzählung der Namen von vier Gewerkschaftspräsidentinnen], we are all leaders. When we sit together and work together, they [männliche Gewerkschafter] do not like it. But women are changing, women are getting strong-

6 Der bengalische Begriff Apa bedeutet große Schwester und wird über die Bezeichnung verwandtschaftlicher Verhältnisse hinaus, in der Regel in freundschaftlichen oder beruflichen Kontexten für die respektvolle Anrede älterer Freundinnen oder Kolleginnen verwendet. 
er. They do not like that, but so what? We don't care! We are working together and we are working for the workers. 85 percent of the workers are female. We know their problems."

Aus der obigen Aussage, die während eines Vernetzungstreffens zwischen Gewerkschafterinnen im Büro der NGO INCIDIN getätigt wurde, treten zudem drei weitere Aspekte zutage: Erstens der Stellenwert des Zusammenhaltes zwischen den Frauen über die Gewerkschaftsgrenzen hinaus. Dies ist insbesondere vor dem Hintergrund der starken Fragmentierung der Gewerkschaften erwähnenswert und eröffnet eine Perspektive zu deren Überwindung durch die Frauensolidarisierung. Zweitens wird deutlich, dass es einer großen Kraftaufwendung, politischem Kampfeswille und der Vernetzung bedarf, um die eigene Position zu behaupten. Und drittens identifiziert Nilanjan einen gegenwärtigen Prozess der Stärkung unter Gewerkschafterinnen und womöglich auch Arbeiterinnen. Letztere Beobachtung Nilanjans ist insofern bezeichnend, als sie der ersten Generation der Bekleidungsgewerkschafterinnen und somit den ,Veteraninnen“ unter ihnen angehört. In den Aussagen ihrer Generation bezüglich der Anfänge ihrer gewerkschaftlichen Laufbahn dominiert ein Kampfvokabular, das verdeutlicht, dass ihr Weg äußerst steinig war. Daher betont Alia Rakib, die in den 1970er Jahre innerhalb einer Partei politisch sozialisiert wurde sowie zur selben Zeit bereits in der Frauenbewegung Bangladeschs engagiert war, und somit unter meinen Interviewpartnerinnen auf den längsten Zeitraum politischer Erfahrung zurückblicken kann:

"In the past we could not reach high positions in trade unions. As women we were deprived. When you see today's women, it is the result of our fight. We have reached this by doing a lot of struggle."

Demgemäß schildert sie, dass sie sich insbesondere zu Beginn ihres gewerkschaftlichen Engagements an manchen Fronten wortwörtlich bewaffnen musste:

"In the first federation in which I worked, when we went out on the streets for rallies we had to take sticks with us. We, the young women, we used to take wooden sticks with us so that we could defend ourselves. Because all the people on the streets were looking at us, they were teasing and harassing us. They used bad words against us. Men also tried to abuse us. (...) Not the men of our federation but the men on the streets."

Unter anderem aufgrund solcher Erfahrungen entschieden sich Rakib und die Kolleginnen ihrer Generation höchstwahrscheinlich auch für eine Strategie der ,Entweiblichung` oder vielmehr Dethematisierung ihres Geschlechts:

„No one thought that I am a woman [lacht]. From the beginning we, me and my female colleagues, did that. No one treated me as a woman. Everybody knows me as a political leader.”

Diese Strategie der Dethematisierung des Geschlechts, das zugunsten der Betonung der politischen oder gewerkschaftlichen Rolle in den Hintergrund gedrängt wird, offenbart einen deutlichen Strategiewandel zwischen der ersten und zweiten Generation von Gewerkschafterinnen im Bekleidungssektor. Während die erste Generation ihr Geschlecht als ,Störfaktor' ansah, den es möglichst zu verbergen galt, da er die politische Arbeit und das persönliche Fortkommen deutlich erschwerte, legitimiert die gegenwärtige Generation ihre Position mit Verweis auf ihr Geschlecht. Dieser Strategiewechsel ist in Verbindung mit nationalen und transnationalen Diskursen der Frauenbewegung zu verorten, die ,Frausein “ weniger als Defizit denn als wertvolle Ressource für das jeweilige Engagement umdeuteten (vgl. Nazneen, 2017; Ferree \& Tripp, 2006). Dieser Diskurswandel ist Bestandteil des bereits erwähnten Gelegenheitsfensters für Gewerkschafterinnen, das zum einen dazu dient, das En- 
gagement im Kontext Bangladeschs zu legitimieren und zum anderen eine vermehrte (transnationale) Koalitionsbildung und Unterstützung mit sich bringt.

Trotz ihrer Erfahrung des zuweilen auch mit physischen Mitteln ausgetragenen Kampfes gegen Männer, stellt Alia Rakib aber unmissverständlich klar, dass es nicht das Anliegen von Frauen sei, gegen einzelne Männer zu kämpfen, sondern vielmehr die gesellschaftliche ,Superstruktur' zu verändern, die im weiteren Verlauf des Gruppeninterviews von einer anderen Teilnehmerin ,Patriarchat' genannt wird:

\footnotetext{
"But now the women learned to fight, they learned about trade unions, they learned about society, they learned about family. What they learned is huge. Now we are always fighting. Now women know how to fight against the super structure. They don't want to go against men. They want to go against the super structure."
}

Rakib identifiziert folglich gegenwärtig sowohl eine umfassendere Bildung von Frauen, die sie dazu befähigt, gesellschaftliche Zusammenhänge zu erkennen und gegen sie anzugehen, als auch die Zunahme einer hiermit einhergehenden Selbstbehauptung. Dass die Selbstbehauptung innerhalb der Gewerkschaften nach wie vor vonnöten ist, betonen sämtliche Interviewpartnerinnen. Sie sehen sich mit einer Vielzahl an teils subtilen Mechanismen konfrontiert, die ihren Stand innerhalb der Organisationen erschweren. Hierzu gehört beispielsweise die Anberaumung von spätabendlichen Treffen, die Gewerkschafterinnen aufgrund familiärer Verpflichtungen, sicherheitsrelevanter Überlegungen oder/und gesellschaftlicher Restriktionen nicht wahrnehmen können. Ebenso werden Gewerkschafterinnen bei Versammlungen häufig just zu dem Zeitpunkt, an dem Diskussionen an Wichtigkeit gewinnen, gebeten, ihren Platz in der ersten Reihe für männliche Gewerkschafter frei zu machen. Zudem wird ein Phänomen der ,rhetorischen Modernisierung' (Wetterer, 2003) konstatiert, das darin besteht, verbal Zugeständnisse zu erbringen und sich in einer Gleichheitsrhetorik zu üben, dieses Gleichheitsversprechen dann aber nicht in die Tat umzusetzen (vgl. hierzu ebenso BILS, 2009, S. 15). Ebenso muss das geschlechterpolitische AgendaSetting nach wie vor erkämpft werden. In diesem Zusammenhang verweist Tamina Robin darauf, dass sie das Thema der sexuellen Belästigung am Arbeitsplatz zwar auf der Agenda ihrer Gewerkschaft platzieren konnte, dies aber nach wie vor der Überzeugungsarbeit bedarf:

"For example, the question of sexual harassment in the factory. Our organization raised this question for the first time and demanded that sexual harassment in the factory should be stopped. Whenever we raise this issue, the other leaders of different organizations they say: 'Oh Tamina-Apa do not raise this question, it is really bad. We should not talk about sexual harassment'. Then I ask: 'What do you mean? If I have a disease and if I want to cure that disease, I should mark the disease first and I should diagnose it and I should treat it. Otherwise how can I cure it?' It is a very big problem here, the sexual harassment."

Bezüglich der Position von Frauen in den Bekleidungsgewerkschaften Bangladeschs kann somit festgehalten werden, dass im Gegensatz zu den Anfängen der Industrie, gegenwärtig Frauen sowohl als Mitglieder innerhalb der Gewerkschaften als auch in Führungspositionen präsent sind. Der Zugang zu den Führungsämtern wurde, ebenso wie geschlechterpolitische Themensetzungen, hart erkämpft und beides bedarf nach wie vor der Verteidigung, obgleich innerhalb der Gewerkschaftsbewegung Zugeständnisse bezüglich der Repräsentation von Frauen erbracht wurden. Dies ist der stärkeren Präsenz und Gegenwehr von Gewerkschafterinnen zuzuschreiben, die insbesondere aufgrund von Bildungs- und Qualifizie- 
rungserfolgen sowie der Allianzbildung über Gewerkschaftsgrenzen hinweg gegenwärtig selbstbewusster auftreten. Kurzum: Es ist die Existenz einer neuen weiblichen, parteipolitisch unabhängigeren und transnational vernetzten Generation von Gewerkschafterinnen zu konstatieren. Überdies sind erste Ansätze eines (Transnational) Social Movement Unionism erkennbar, da beispielsweise die Kooperation mit progressiven NGOs, wie etwa INCIDIN gesucht wird, die ihrerseits in ihrer Arbeit von einer TNGO unterstützt wurde, um die Anliegen von Frauen in Gewerkschaften zu stärken.

\section{Resümee: Potenziale von TSMU im Bekleidungssektor Bangladeschs}

Entgegen Rahman und Langfords (2010) abschlägigem Urteil bezüglich der Realisierungsmöglichkeiten von (T)SMU in Bangladesch möchte ich abschließend vor dem Hintergrund der geschilderten Beobachtungen die Potenziale dieser Organisierungsform in folgenden fünf zentralen Punkte hervorheben: Erstens konnten Kooperationen zwischen Gewerkschaften und (T)NGOs, Frauen in ihrem ,Marsch durch die Gewerkschaften ' bereits unterstützen und somit zu deren Stärkung beitragen. Dies geht mit einer inhaltlichen Demokratisierung der Gewerkschaften einher, da die Gewerkschafterinnen beanspruchen, die Problemlagen der ArbeiterInnen in einer ganzheitlicheren Perspektive anzugehen, die auch Aspekte umfasst, welche zuvor aufgrund ihres vermeintlich privaten Charakters außen vor gelassen wurden. So ist die Skandalisierung von sexueller Gewalt am Arbeitsplatz oder die Thematisierung der Mehrfachbelastung von Frauen durch Fabrik-, Haushalts- und Fürsorgearbeit auf die Interventionen der Gewerkschafterinnen zurückzuführen.

Mit der stärkeren Präsenz von Frauen und der durch sie erwirkten thematischen Diversifizierung geht zweitens die Verhandlung und Transformation von Geschlechterbeziehungen und -verhältnissen in Gewerkschaften sowie hierüber hinaus einher. Hiervon zeugen sowohl Hinterfragungen der gesellschaftlichen Stigmatisierung von Sexarbeit seitens der Gewerkschafterinnen als auch die Auseinandersetzung um geschlechtlich kodierte Rollenzuschreibungen angesichts der Übernahme eines gewerkschaftlichen Postens. Die Nachhaltigkeit dieses Prozesses wird unter anderem durch die NGO INCIDIN im Rahmen von Gender Mainstreaming-Komponenten in Capacity Building-Maßnahmen versucht zu gewährleisten.

Drittens hat das Engagement von Trade Union Support Organisations und (T)NGOs zu wichtigen Qualifizierungserfolgen der Gewerkschafterinnen geführt. Durch vergleichbare Angebote könnte zukünftig die Rolle der ArbeiterInnen in den Gewerkschaften gestärkt und somit am ungleichen Kräfteverhältnis zu den studierten Berufsgewerkschaftern gerüttelt werden. Die Basisnähe der Gewerkschaften wäre hierdurch eher gegeben.

Hiermit zusammenhängend deutet viertens die gezielte Nachfrage seitens der Arbeiterinnen nach Gewerkschafterinnen auf eine größere Akzeptanz von Gewerkschaften und somit auf einen perspektivisch höheren Grad der Organisierung der weit überwiegend weiblichen Beschäftigten hin.

Fünftens birgt das Moment der Vernetzung und Frauensolidarisierung über gewerkschaftliche Grenzen hinaus, das durch die NGO INCIDIN Unterstuitzung findet, die Per- 
spektive der Überwindung der Fragmentierung der Gewerkschaftslandschaft, was letztlich wiederum mit einer Rehabilitierung und Stärkung der Gewerkschaften einhergehen könnte.

Trotz dieses Potenzials, das in Kooperationen von Gewerkschaften mit (T)NGOs liegt, bleiben abschließend ebenso die limitierenden Faktoren dieser Organisierungsstrategie festzuhalten: Zum einen existieren aufgrund des skizzierten Prozesses der Depolitisierung der bangladeschischen Zivilgesellschaft nur wenige Organisationen, deren Engagement mit dem von INCIDIN vergleichbar ist. Zum anderen müssen im Falle bestehender Kooperationen Gewerkschaften wie auch NGOs, angesichts vielfältiger Abhängigkeiten im transnationalen Gefüge (vgl. Zajak, 2017), Tendenzen der Depolitisierung oder gar Disziplinierung stetig entgegenarbeiten (vgl. Fink, 2018). TSMU vor diesem Hintergrund aber schlicht als Option für Bangladesch zu verwerfen, würde bedeuten, das oben skizzierte Potenzial dieser Mobilisierungsform für Organisierung und gewerkschaftliche Erneuerung nicht anzuerkennen und zudem Gelegenheitsfenster der Organisierung zu verspielen. Für die Labour Studies bedeutet dies zweierlei: Erstens muss der eindimensionale Fokus auf Beschäftigte als einer vermeintlich einheitlichen Interessensgruppe durch eine Analyse ihrer spezifischen Verortung mittels beispielsweise des Analyseparadigmas der Intersektionalität ersetzt werden. So konnten in diesem Beitrag durch die Differenzierung der Gewerkschaftsmitglieder nach Geschlecht, Alter, Klasse und geographischer Lokalität sowohl die Schwierigkeiten der Organisierung (männliche Dominanz der Gewerkschaften, desolater Zustand der Gewerkschaften bedingt durch Geschichte des Kolonialismus und Imperialismus), die Differenzen innerhalb der Gewerkschaften (Generations-, Geschlechter- und Bildungsunterschied) sowie die Chancen für Revitalisierung und Mobilisierung (Nachfrage nach Gewerkschafterinnen, thematische Diversifizierung durch Frauen, Solidarisierung über Gewerkschaftsgrenzen hinweg, transnationale Ressourcen und Gelegenheitsfenster) herausgearbeitet werden. Die gleichzeitige Berücksichtigung der Mikroebene (Verhandlung von geschlechtlich kodierten Identitäten) sowie der Meso- und Makroebene (Verfasstheit von Gewerkschaften und zivilgesellschaftlichen Organisationen, Geschlechterverhältnisse innerhalb dieser Organisationen, transnationale zivilgesellschaftliche Diskurse und labour governance) erlaubt hierbei, die unterschiedlichen Ebenen in Beziehungen zu setzen, sowie Wechselwirkungen, Diskursverschiebungen und nicht zuletzt Gelegenheitsfenster zur Organisierung, die sich aus einer Kongruenz nationaler und transnationaler Diskurse ergeben, zu identifizieren.

In Zusammenhang mit dieser analytischen Diversifizierung muss innerhalb der Labour Studies sowie der Gewerkschaftsbewegung zweitens eine tatsächliche Offenheit gegenüber sozialen Bewegungen praktiziert werden, die darin besteht, deren Anliegen als gleichberechtigt zu akzeptieren. Für Forschungen zu SMU bedeutet dies konkret, von der vermeintlich avantgardistischen Position von Gewerkschaften Abstand zu nehmen und sich gegenüber den demokratisierenden Interventionen, die von den Angehörigen der sozialen Bewegungen ausgehen, wachsam zu zeigen. In diesem Sinne sind Studien, die Organisierungsformen jenseits des traditionellen gewerkschaftlichen Musters zum Gegenstand haben, zu begrüßen (vgl. bspw. Nowak, 2017; Zajak, Egels-Zandén \& Piper, 2017). In dieser Annäherung an soziale Bewegungen, wäre es zudem im Sinne eines Akzeptanzgewinns seitens der zuvor von den Gewerkschaften und Labour Studies vielfach vernachlässigten Gruppen nicht zuletzt hilfreich, die historischen Vorläufer (der Watermanschen Prägung) von SMU, 
wie beispielsweise die Frauen- oder amerikanische Bürgerrechtsbewegung, als solche anzuerkennen und zu würdigen.

\section{Literatur}

Alvarez, S. E. (1999). The Latin American Feminist NGO 'Boom'. International Feminist Journal of Politics, 2, 181-209. doi: 10.1080/146167499359880

Alvarez, S. E. (2009). Beyond NGOization? Reflections from Latin America. Development, 52 (2), 175-184. doi: 10.1057/dev.2009.23

Anner, M. (2015). Stopping the Race to the Bottom. Challenges for Workers' Rights in Supply Chains in Asia. Berlin: Friedrich-Ebert-Stiftung.

Anner, M., Bair, J. \& Blasi, J. (2013): Towards Joint Liability in Global Supply Chains: Addressing the Root Causes of Labor Violations in International Subcontracting Networks. Comparative Labor Law and Policy Journal, 35 (1), 1-43.

Anner, M. \& Evans, P. (2004). Building Bridges Across a Double Divide: Alliances between US and Latin American Labour and NGOs. Development in Practice, 14 (1-2), 34-47. doi: 10.1080/0961452032000170613

Badruddin, U. (2004). The Emergence of Bangladesh: Class Struggles in East Pakistan, 1947-1958, Vol.1. Karachi: Oxford University Press.

Bass, G. N. (2012). Organized Labor and U.S. Foreign Policy: The Solidarity Center in Historical Context. FI Electronic Theses and Dissertations. Paper 752. Abgerufen von http://digitalcommons.fiu.edu/etd/752

BGMEA (2017). Trade Information. Abgerufen am 08.08.2017 von http://bgmea.com.bd/home/pages/TradeInformation.

BILS (Bangladesh Institute of Labour Studies). (2009). Women's Participation in Trade Unions in Bangladesh. Status, Barriers and Overcoming Strategies. Abgerufen von http://www.ilo.org/wcmsp5/groups/public/@asia/@ro-bangkok/@ilodhaka/_documents/publication/wcms_125374.pdf

Britwurm, A. O., Douglas, K. \& Ledwith, S. (2012). Women, Gender and Power in Trade Unions. In M. Williams \& S. Mosoetsa (Hrsg.), Labour in the Global South: Challenges and Alternatives for Workers (S. 41-64). Geneva: International Labour Office.

Broadbent, K. \& Ford, M. (2008). Introduction. In K. Broadbent \& M. Ford (Hrsg.), Women and Labour Organizing in Asia. Diversity, Autonomy and Activism (S. 1-15). Routledge: New York.

Crenshaw, K. (1991). Mapping the Margins. Intersectionality, Identity Politics, and Violence against Women of Color. Stanford Law Review, 43 (6), 1241-1299. doi: 10.2307/1229039

Dannecker, P. (2000). Collective Action, Organisation Building and Leadership. Women Workers in the Garment Sector in Bangladesh. Gender and Development, 8 (3), 31-39. doi: $10.1080 / 741923779$

Dannecker, P. (2002): Between Conformity and Resistance: Women Garment Workers in Bangladesh. Dhaka: Dhaka University Press.

Faruque, A. A. (2009). Current Status and Evaluation of Industrial Relation System in Bangladesh. ILO. Abgerufen von www.ilo.org/wcmsp5/groups/public/@asia/@robangkok/@sro-new_delhi/documents/ publication/wcms_123336.pdf

Fink, E. (2014). Trade Unions, NGOs and Transnationalisation: Experiences from the Ready-made Garment Sector in Bangladesh. ASIEN, 130, 42-59.

Fink, E. (2018). Transnationaler Aktivismus und Frauenarbeit. Social Movement Unionism in Bangladesch. Frankfurt/New York: Campus. 
Feldman, S. (2003). Paradoxes of Institutionalisation. The Depoliticisation of Bangladeshi NGOs. Development in Practice, 13 (1), 5-26. doi: 10.1080/0961452022000037955

Ferree, M. M. \& Tripp, A. M. (Hrsg.) (2006). Global Feminism. Transnational Women's Activism, Organizing, and Human Rights. New York: New York University Press.

Hossain Ovi, I. (23. April 2017). Garment Workers' Rights Still a Far Cry. Dhaka Tribune. Abgerufen von http://www.dhakatribune.com

Kabeer, N. \& Haq Kabir, A. (2009). Citizenship Narratives in the Absence of the Working Poor in Bangladesh, Working Paper 331, Institute of Development Studies at the University of Sussex Brighton, 1-65.

Kabeer, N., Mahmud, S. \& Isaza Castro, J. G. (2010). NGO's Strategies and the Challenge of Development and Democracy in Bangladesh, Working Paper 343, Institute of Development Studies at the University of Sussex Brighton, 1-66.

Kainer, J. (2009). Gendering Union Renewal: Women's Contributions to Labour Movement Revitalization. In J. R. Foley \& P. L. Baker (Hrsg.) (2009), Unions, Equity, and the Path to Renewal (S. 15-39). Vancouver: UBC Press.

Karim, L. (2001). Politics of the Poor? NGOs and Grassroots Political Mobilisation in Bangladesh, Polar, 24 (1), 92-107. doi: 10.1525/pol.2001.24.1.92

Karim, L. (2016). Resistance and its Pitfalls: Analyzing NGO and Civil Society Politics in Bangladesh. In D. Courpasson \& S. Vallas (Hrsg.), The SAGE Handbook of Resistance (S. 461-475). Thousand Oaks, CA: SAGE. doi: 10.4135/9781473957947.n25

Lewis, D. (2011). Bangladesh. Politics, Economy and Civil Society. Cambridge: Cambridge University Press. https://doi.org/10.1017/CBO9781139017138

Lutz, H., Herrera Vivar, M. T. \& Supik, L. (Hrsg.). (2010). Fokus Intersektionalität: Bewegungen und Verortungen eines vielschichtigen Konzeptes. Wiesbaden: VS Verlag für Sozialwissenschaften. doi: 10.1007/978-3-531-92555-4

Moazzem, K. \& Islam, A. (2015). Moving Beyond the Shadow of the Rana Plaza Tragedy. In Center for Policy Dialogue (Hrsg.), Search of a Closure and Restructuring Strategy. Fourth Monitoring Report. Abgerufen von http://cpd.org.bd/wp-content/uploads/2013/07/Fourth-Monitoring-Report-Rana-Plaza-TragedyFINAL-April-2015.pdf

Moody, K. (1997). Workers in a Lean World: Unions in the International Economy. London and New York: Verso.

Nazneen, S. (2017). The Women's Movement in Bangladesh. A Short History and Current Debates. Friedrich-Ebert-Stiftung, Dhaka.

Nowak, J. (2017). Mass Strikes in India and Brazil as the Terrain for a New Social Movement Unionism. Development and Change, 48 (5), 965-986. doi: 10.1111/dech.12320

Rahman, Z. \& Langford, T. (2010). The Limitations of Global Social Movement Unionism as an Emancipatory Labour Strategy in Majority World Countries. Socialist Studies, 6 (1), 45-64. doi: $10.18740 / \mathrm{S} 44597$

Rahman, Z. \& Langford, T. (2014). International Solidarity or Renewed Trade Union Imperialism? The AFL-CIO and Garment Workers in Bangladesh, Working USA: The Journal of Labor and Society, 17 (2), 169-186. doi: 10.1111/wusa.12106

Rock, M. (2001). The Rise of the Bangladesh Independent Garment-Workers' Union (BIGU). In J. Hutchison \& A. Brown (Hrsg.), Organising Labour in Globalising Asia (S. 27-47). London and New York: Routledge.

Schmidt Camacho, A. (1999). On the Borders of Solidarity: Race and Gender Contradictions in the "New Voice" Platform of the AFL-CIO. Social Justice, 26 (3 [77]), 79-102. 
Scipes, K. (2012). Globalization from Below. Labor Activists Challenging the AFL-CIO Foreign Policy Program. Critical Sociology, 38 (2), 303-323. doi: 10.1177/0896920511399938

Scipes, K. (2014). Social Movement Unionism or Social Justice Unionism? Disentangling Theoretical Confusion within the Global Labor Movement. Class, Race and Corporate Power, 3 (2), Article 9. Abgerufen von http://digitalcommons.fiu.edu/classracecorporatepower/vol2/iss3/9

Serdar, A. (2012). Strategies for Revitalizing Labor Movement: Union Organizing and Building Alliances with Community in Argentina. Economic and Industrial Democracy, 33 (3), 403-420. doi: 10.1177/0143831X11411326

Shlyk, A. (2009). Social Movement Unionism in Poland. Towards Revitalization of Organized Labor? Theory in Action, 2 (1), 158-184. doi: 10.3798/tia.1937-0237.08034

Sobhan, R. (1982). The Crisis of External Dependence. The Political Economy of Foreign Aid to Bangladesh. Dhaka: University Press Limited.

Stiles, K. (2002). International Support for NGOs in Bangladesh. Some Unintended Consequences. World Development, 30 (5), 835-846. doi: 10.1016/S0305-750X(02)00012-8

Van Schendel, W. (2009). A History of Bangladesh. Cambridge: Cambridge University Press. doi: 10.1017/CBO9780511997419

Von Holdt, K. (2002). Social Movement Unionism: The Case of South Africa. Work, Employment and Society, 16 (2), 283-304. doi: 10.1177/095001702400426848

Waterman, P. (1993). Social Movement Unionism: A New Model for a New World Order? Review, $16(3), 245-278$.

Waterman, P. (2004). Adventures of Emancipatory Labour Strategy As the New Global Movement Challenges International Unionism. Journal of World-System Research, 10 (1), 217-253. doi: 10.5195/JWSR.2004.315

Wetterer, A. (2003). Rhetorische Modernisierung. Das Verschwinden der Ungleichheit aus dem zeitgenössischen Differenzwissen. In G.-A. Knapp \& A. Wetterer (Hrsg.), Achsen der Differenz. Gesellschaftstheorie und feministische Kritik 2 (S. 286-319). Münster: Westfälisches Dampfboot.

White, S. C. (1999). NGOs, Civil Society, and the State in Bangladesh. The Politics of Representing the Poor. Development and Change, 30 (2), 307-326. doi: 10.1111/1467-7660.00119

Zajak, S. (2017): International Allies, Institutional Layering and Power in the Making of Labour in Bangladesh. Development and Change, 48 (5), 1007-1030. doi: 10.1111/dech.12327

Zajak, S., Egels-Zandén N. \& Piper, N. (2017). Networks of Labour Activism: Collective Action across Asia and Beyond. An Introduction to the Debate. Development and Change, 48 (5), 899 921. doi: 10.1111/dech.12336 


\section{Transnationale Bündnisse von Gewerkschaften und NGOs. Strategien in Interaktion ${ }^{* *}$}

\section{Zusammenfassung}

Globalisierte Produktionsmuster erschweren traditionelle Arbeiternehmervertretung und stellen Gewerkschaften und NGOs vor neue Herausforderungen. Private Governanceformen und die Nutzung von Konsumentenmacht stehen zur Debatte. Kooperationen von Gewerkschaften und NGOs gelten als erfolgsversprechende Bündnisse in einer globalen, unregulierten Ökonomie. Dieser Artikel analysiert die Strategien dieser neuen Bündnisse in der transnationalen Arbeitsregulierung. Strategien werden definiert als interaktive, multiple Sequenzen erfolgsorientierten Handelns im Zeitverlauf. Im Mittelpunkt dieses Beitrags stehen strategische Interaktionen, die zeigen, auf welche Weise Gewerkschaften und NGOs gemeinsam handeln - nicht trotz, sondern wegen originär unterschiedlicher strategischer Präferenzen. Anhand eines Fallbeispiels werden typische Strategien von Gewerkschaften und NGOs und ihr Zusammenspiel in der transnationalen Governancearchitektur von Arbeit nachgezeichnet.

Schlagwörter: Gewerkschaft, NGOs, Koalitionen, transnationale Regulierung von Arbeit

\section{Transnational Coalitions of Labour Unions and NGOs. Strategies in Interaction}

\section{Abstract}

Globalised production regimes hamper traditional ways of workers representation and present new challenges for labour unions and NGOs. Here, private forms of governance and consumer power are under discussion. Cooperation of labour unions and NGOs represent promising coalitions in a globalized, unregulated economy. This article analyses these new coalitions and their common strategies to transnationally regulate labour. Strategies are defined as interactive, multiple sequences of successoriented activities over time. This paper focuses specifically on strategic interactions that outline in which ways labour unions and NGOs act jointly - not despite, but because of originally different stra-

* Melanie Kryst, Universität Marburg, FB Gesellschaftswissenschaften und Philosophie, 35037 Marburg. E-Mail: melanie.kryst@gmx.de.

** Artikel eingegangen: 31.08.2017, revidierte Fassung akzeptiert nach doppelt-blindem Begutachtungsverfahren: 14.3 .2018 
tegic preferences. Utilizing a case study approach the article retraces typical trade union and NGO strategies and their interplay in the realm of transnational labour governance.

Key words: strategies, labour unions, NGOs, coalitions, interactive mechanisms, transnational labour governance (JEL: J 51; J 83)

\section{Einleitung}

In Zeiten der Globalisierung sehen sich Gewerkschaften und NGOs (Non-governmental organizations) weltweit verzweigten Produktionswegen gegenübergestellt, die traditionelle Arbeitnehmervertretung erschweren. Strategien von Arbeitsaktivisten in globalen Governancekontexten sind vielfältig. Der transnationale Raum wird von Gewerkschaften und NGOs erschlossen (Pries, 2010). Jenseits von Bemühungen um transnationalen sozialen Dialog oder (national)staatliche Regulierung entwickeln sich private Governanceformen, wie z.B. Labeling oder Verhaltenskodizes, und multinationale Unternehmen werden durch Konsumentenkampagnen unter Druck gesetzt. Der Markt wird zur neuen politischen Arena (Bartley, 2007; King \& Pearce, 2010).

Transnationale Kooperationen zwischen Gewerkschaften und NGOs werden als erfolgsversprechende Bündnisse in einer globalen, unregulierten Ökonomie gewertet (s. Übersicht in Fichter, Gester \& Zeuner, 2004). Sowohl in der Gewerkschafts- als auch in der Bewegungsforschung werden sie unter dem Vorzeichen einer möglichen Stärkung der Handlungsfähigkeit diskutiert. Implizit werden komplementäre Funktionen der beiden Akteursgruppen angenommen: Gewerkschaften als traditionelle Akteure der Arbeitsregulierung, stark verankert in den staatlichen Politikarenen und erprobt in Verhandlungen mit Unternehmen, scheinen ein ideales Pendant zu kleinen, schnell agierenden und medienerfahrenen NGOs zu bilden. Eine schlagkräftige Paarung kann entstehen. Bisherige Forschung und Praktikereinsichten beschäftigen sich vor allem mit der Entstehung und Gestalt von Gewerkschafts-NGOBündnissen (zum Beispiel Krüger, 2002; Anner \& Evans, 2004; Braun \& Gearhart, 2004; Egels-Zandén \& Hyllman, 2011). Es werden auf der einen Seite bündnisbildende Faktoren, wie zum Beispiel eine geteilte Zielperspektive (Gallin, 2000) oder Arbeitsweise (Della Porta, 2006), beschrieben. Auf der anderen Seite werden mögliche Konfliktpunkte betont, etwa durch eine unterschiedliche Organisationsidentität (Ford, 2009).

Wenig beachtet bleibt neben der Bündnisbildung das gemeinsame Handeln von Gewerkschaften und NGOs, das bisher nur in wenigen Ausnahmen untersucht wurde (Ford, 2009; Kryst, 2012; Egels-Zandén, Lindberg \& Hyllman, 2015). Dieser Beitrag geht der Frage nach, welche Strategien Gewerkschaften und NGOs gemeinsam in der transnationalen Governancearchitektur von Arbeit entwickeln. Mittels eines Ansatzes, der Strategien als Sequenzen erfolgsorientierten Handelns definiert (aufbauend auf Jasper 2004, 2012; Raschke \& Tils, 2013), werden Strategien in ihrem dynamischen, wechselseitigen Zusammenspiel erfasst. Eine induktive Bündnisanalyse zeigt, wie Gewerkschaften und NGOs in ihrer Strategiebildung den transnationalen sozialen beziehungsweise tripartistischen Dialog mit dem transnationalen Aktivismus kombinieren. Strategien von Gewerkschaften und NGOs befinden sich in Interaktion - nicht trotz, sondern wegen originär unterschiedlicher Präferenzen der Bündnispartner. 
Im Folgenden wird nach einer Gegenüberstellung der Ausgangsbedingungen für Gewerkschaften und NGOs und deren Zusammenspiel in Bündnissen ein interaktionistischer Strategiebegriff entwickelt, der auf jüngsten Forschungsansätzen aufbaut. Übersetzt in den Kontext der globalen Governancearchitektur von Arbeit ermöglicht ein Analyserahmen die Untersuchung von Gewerkschafts- und NGO-Strategien in Interaktionen. Aufbauend auf Ergebnissen einer exemplarischen Fallstudie des European Banana and Agro Industrial Product Action Networks (EUROBAN) (Kryst, 2017) werden zunächst Strategien des Gewerkschafts-NGO-Bündnisses typologisiert. In der Darstellung der Interaktionsmechanismen der beiden Strategietypen werden schließlich deren dynamischen Kombinationen und Interdependenzen benannt, und damit der interaktive Charakter der Strategien von Gewerkschaften und NGOs in transnationalen Bündnissen zur Arbeitsregulierung betont.

\section{Strategien von Gewerkschaften und NGOs in der transnationalen Governancearchitektur von Arbeit}

Sowohl die Gewerkschafts- als auch die Bewegungsforschung zeigt ein zunehmendes Interesse an Bündnisbildungen vor dem Hintergrund der Globalisierung. Die interagierenden Strategien der beiden Akteursgruppen - bislang noch mangels eines ausgeprägten Strategiebegriffs vernachlässigt - stehen im Fokus dieses Beitrags.

\subsection{Gewerkschafts-NGO-Bündnisse}

Bündnisse von Gewerkschaften und NGOs werden zumindest implizit unter der Annahme komplementärer Merkmale der ,alten' und ,neuen“ Akteure der Arbeitsregulierung beschrieben (z.B. in Krüger, 2002; Scherrer, 2002, S. 124-125). Gewerkschaften und NGOs sind in sich keine homogenen Gruppen, dennoch sind sie jeweils geprägt von charakteristischen Organisationsformen und Arbeitsweisen, Handlungssphären, sowie Problem- und Interessenlagen in der Arbeitsregulierung. Sie erscheinen damit als distinktive Bündnispartner, die die Problematik der globalen Arbeitsstandards auf unterschiedliche, aber potentiell kombinierbare Weise bearbeiten.

Gewerkschaften auf der einen Seite sind zentral durch ihre Mitglieder definiert, legitimiert und diesen gegenüber verpflichtet. Auf ihrer Primärmacht, den Beschäftigten in Unternehmen, gründet sich ihre Organisationsmacht, die als zentral für die Handlungsfähigkeit und Stärke von Gewerkschaften gegenüber Arbeitgebern gilt (Schroeder, 2014, S. 23). Als Interessengruppen bringen sie zudem die Interessen ihrer Mitglieder im politischen Willensbildungs- und Entscheidungsprozess zur Geltung. Die Verbesserung von Arbeitsbedingungen ist das Kerngeschäft von Gewerkschaften in den Betrieben, den Tarifverhandlungen oder dem politischen Raum - den drei klassischen Arenen gewerkschaftlichen Handelns (Schroeder, 2009). Als professionalisierte Organisationen verstanden, lassen sich Gewerkschaften durch eine definierte Anzahl an Mitgliedern, ein eher passives Mitgliederverständnis, gewählte Vertreter sowie Bürokratisierung und Zentralisierung charakterisieren (Avdagić \& Crouch, 2006).

Vor allem Gewerkschaften sind vor dem Hintergrund wirtschaftlicher Globalisierungsprozesse mit Problemen ihrer Einflussmöglichkeiten konfrontiert. Zum einen erodiert das 
Verhältnis zu Partnern in der politischen Sphäre (Evans 2010, S. 356), zum anderen sind Unternehmen durch globale Produktionsprozesse und die Logik des Wettbewerbsstaates weniger verpflichtungsfähig (Streeck, 1996, S. 186ff.). Gewerkschaften haben in dieser Situation sinkende Mitgliederzahlen zu verzeichnen (Streeck \& Rehder, 2005, S. 65). Internationales Gewerkschaftshandeln wird erschwert durch mangelhafte Organisationsstrukturen jenseits der nationalen Ebene (Koch-Baumgarten, 1999, S. 11f.) und verbleibt bisweilen als „Restposten“ (Reutter \& Rütters 2003, S. 512).

Dennoch, den Gewerkschaften kann noch immer eine Verhandlungsmacht in der globalen Governancearchitektur von Arbeit eingeräumt werden. Ansätze des pragmatischen Internationalismus messen Ergebnisse internationalen Gewerkschaftshandelns an zurückgeschraubten, realitätsnäheren Erwartungen hinsichtlich der Regulierungsdichte und -intensität. Gewerkschaften sind - so staatliche und gesellschaftliche Strukturen es ihnen ermöglichen - zentrale Akteure im Bereich der Selbstregulierung von Arbeit (Koch-Baumgarten, 2006, 2011). Sie tragen zu Komponenten einer transnationalen Governancearchitektur von Arbeit bei: durch Lobbyarbeit der globalen Gewerkschaftsverbände in internationalen Organisationen wie der Internationalen Arbeitsorganisation (ILO), durch internationale Rahmenvereinbarungen (IFAs) oder gar durch ein einzigartiges internationales Kollektivvertragssystem in der Transportschifffahrt sowie durch ihre Teilnahme an NGO-Bündnissen (Koch-Baumgarten \& Kryst, 2015). Diese besondere Rolle der Gewerkschaften sollte in Beschreibungen privater Governanceformen von Arbeit (Hassel, 2008) nicht weiter vernachlässigt werden.

NGOs auf der anderen Seite sind „Organisationen des ,dritten Sektors““(Janett, 1997), die sich zwischen die Sphären von staatlicher Gewalt und wirtschaftlicher Macht schieben. NGOs werden hier verstanden als der institutionelle Kern von sozialen Bewegungen (Cohen \& Rai, 2000, S. 12). Als Organisationen bilden sie das Gestell und den nach außen gerichteten Arm der sozialen Bewegung (Janett, 1997, S. 146), wobei professionelle Vereinigungen und Gewerkschaften von diesem Verständnis ausgeschlossen sind (Roth, 2005: 92ff.). Hinsichtlich der Ziele und Interessenlage lässt sich eine große Bandbreite von Themen ausmachen. Hier wird der Begriff eingeschränkt verwendet für politikorientierte NGOs (Heins, 2002, 132f.) in der Arbeitsregulierung, an anderer Stelle als „labour NGOs“ (Ford, 2009), oder „labor-based NGOs“ (Bronfenbrenner, 2007) beschrieben.

NGOs erfahren seit den 1990er Jahren verstärkte Aufmerksamkeit als relevante Akteure auf internationaler Ebene. Dahinter steht die Annahme, dass sie als zivilgesellschaftliche Akteure in der Weltpolitik zu mehr Demokratie und Effektivität in der Politikumsetzung verhelfen könnten (s. Übersicht in Klein, Walk \& Brunnengräber, 2005). Als NGONetzwerke mit spezifischen transnationalen Handlungsmöglichkeiten (Keck \& Sikkink, 1998) verorten sie sich in der transnationalen Politiksphäre. In der transnationalen Governancearchitektur von Arbeit bleiben sie bisweilen aber hinter den garantieren Einflusskanälen der Gewerkschaften, etwa bei der ILO, zurück (Koch-Baumgarten \& Kryst, 2015).

Besonders bei privaten Governanceformen werden NGOs als zentrale Akteure betont (Hassel, 2008): Die Unterstützung von Labels, die Forderung von Verhaltenskodizes, die Inszenierung von Protesten oder Kampagnen gegenüber transnationalen Unternehmen gehören zum Standardrepertoire von NGOs. Sie wirken mit diesen Instrumenten an der Institutionenbildung im Markt mit (Bartley, 2007; King \& Pearce, 2010). Durch die mangelhaf- 
te Umsetzung der freiwilligen Selbstregulierung von Unternehmen werden NGOs zudem erneut in regulatorischen Initiativen der Arbeitsregulierung in der staatlichen Sphäre aktiv (Kryst, 2012; Fransen \& Burgoon, 2015).

Bündnisbildung wird für beide Akteursgruppen als erfolgsversprechend eingestuft. Ein Bündnis wird hier definiert als eine abgrenzbare Organisationseinheit, die durch die Zusammenlegung von Ressourcen unabhängiger Organisationen aufgebaut wird (Mayer, 2009, S. 220). In der Gewerkschaftsforschung sind Zusammenschlüsse besonders auf globaler Ebene von Interesse (Müller, Platzer \& Rüb 2010), und „coalitional power“ (Brookes, 2013) wird als eine Machtbasis der Gewerkschaften beschrieben. In der Bewegungsforschung werden Bündnisse ebenfalls als relevant für den Erfolg der Bewegung angesehen, sind bislang aber erst in Ansätzen erforscht (Van Dyke \& McCommon 2010). Eine neue Perspektive auf Revitalisierungsstrategien der Gewerkschaften konstatiert Bündnisse mit NGOs als eine Möglichkeit der Gewerkschaften, sich neu zu behaupten (Baccaro, Haman \& Turner, 2003; Frege \& Kelly 2003). Parallel entsteht ursprünglich mit Blick auf Gewerkschaftshandeln im globalen Süden der Ansatz des Social Movement Unionism, der die Bedeutung der Arbeiterbewegung als politischen Bewegungsakteur in Erinnerung ruft und die Bündnisbildungen der Gewerkschaften mit sozialen Bewegungs- oder Gemeindeorganisationen betont (Bronfenbrenner, 2007; Fairbrother \& Webster, 2008).

Konkrete empirische Beispiele von Gewerkschafts-NGO-Bündnissen im Bereich der Arbeitspolitik finden sich verstärkt seit Beginn der 2000er Jahre (z.B. Krüger 2002; Anner \& Evans, 2004; Spooner, 2004; Arenas, Lozano \& Albreda, 2009). Die bisherigen Arbeiten und Praktikereinsichten sind erkenntnisreich, da sie Gemeinsamkeiten und Unterschiede der beiden Akteursgruppen herausarbeiten und daraus potentiell resultierende Spannungen sowie bündnisstärkende Faktoren betonen. Diese sind zum Beispiel funktionelle Faktoren auf Organisationsebene oder die Identität der Organisation (Braun \& Gearhart, 2004), die Verortung in den verschiedenen Sphären der Arbeitsregulierung (Egels-Zandén \& Hyllman, 2011, S. 254) oder die Zielsetzungen (Gallin, 2000, S. 28) und Interessenlagen von Gewerkschaften und NGOs (Compa, 2004). Nur wenige Ausnahmen erforschen bisher jedoch analytisch fundiert das gemeinsame Handeln von Gewerkschaften und NGOs anhand empirischer Fallbeispiele (Ford, 2009; Kryst, 2012; Egels-Zandén, Lindberg \& Hyllman, 2015).

Insgesamt zeigt sich in der bisherigen Forschung ein starker Fokus auf Entstehungsbedingungen von Bündnissen, wobei deren gemeinsames Handeln noch weitestgehend unerforscht bleibt. Es werden Gegensätze zwischen den beiden Akteursgruppen herausgearbeitet, und zugleich Möglichkeiten der Überwindung eben dieser aufgeführt. Unklar bleibt, wie sich das Handeln in Bündnissen kombinieren lässt - selbst, wenn die Akteursgruppen sich nicht auf eine gemeinsame Strategie einigen. Daher wird der Blick auf das Forschungsdesiderat des gemeinsamen strategischen Handelns von Gewerkschaften und NGOs in transnationalen Bündnissen der Arbeitsregulierung gerichtet, welchem im Folgenden ein interaktiver Strategiebegriff gerecht werden soll.

\subsection{Eine interaktionistische Strategieanalyse}

Lange Zeit war der Strategiebegriff in der politikwissenschaftlichen Forschung mit militärischem Handeln (Überblick: Münkler, 2010, S. 45) und den internationalen Beziehungen (Überblick: Schwarz, 2008, S. 102) verknüpft und fand später in der Spieltheorie Verwen- 
dung. Heute wird ein allzu negativ konnotiertes Strategieverständnis kritisiert (Saretzki, 2010, S. 125). Mit dem cognitive turn in den Sozialwissenschaften kommen schließlich Ansätze auf, die sich von bloßen interessengeleiteten Annahmen absetzen. An den Strategiebegriff knüpfen zunächst Ansätze der Politikfeldforschung an, die das Zusammenspiel von (kollektiven) politischen Akteuren untersuchen. Die Bedeutung von Werthaltungen, Argumenten und Ideen vor Kosten-Nutzen-Kalkulationen bei Entscheidungen in Politikfeldern werden betont (z.B. Sabatier, 1998).

Insbesondere in der deutschsprachigen politikwissenschaftlichen Forschung ist in den letzten Jahren ein Aufleben der Debatte über politische Strategie zu beobachten, wobei versucht wird, Grundlagen politischer Strategieanalysen (Raschke \& Tils, 2013; Wiesendahl, 2010) in die praxistaugliche Anwendung zu bringen. Diese beratungsorientierten Überlegungen fokussieren jedoch auf Regierungen und Parteien. Die Betonung kommunikativer Elemente führt zu Überschneidungen mit der Kommunikations- (Schmitt-Beck, 2008) und Political Leadership-Forschung (Glaab, 2008).

Für Gewerkschaften spielen Fragen der Strategie von Anbeginn der Arbeiterbewegung eine Rolle. Historisch ist die Strategie der Einheitsfront und der Volksfront in den 1920er und 1930er Jahren zu nennen (Abendroth 1969). Später wurde in der Gewerkschaftsforschung in den 1970er Jahren implizit die Strategiefrage im klassischen Gegensatz zwischen konfliktorischem und kooperativem Handeln gegenüber Arbeitgebern aufgegriffen (Bergmann, Jacobi \& Müller-Jentsch 1975, S. 26). Eine strenge bipolare Abgrenzung wird heute aber nicht mehr vertreten (Müller-Jentsch, 2008, S. 64ff.). Von strategic choice der Gewerkschaften wird jüngst vor allem vor dem Hintergrund schwindender Einflussmöglichkeiten der Gewerkschaften im globalen Raum und den daraus resultierenden Revitalisierungsstrategien gesprochen (Frege \& Kelly, 2003). Daneben werden vereinzelt Konzepte des Organisationslernens auf Gewerkschaften übertragen (Rehder, 2008).

In der Bewegungs- beziehungsweise NGO-Forschung sind Strategien implizit präsent bei der Frage der Aktionsformen, prominent als bewegungsspezifisches Aktionsrepertoire konzeptualisiert (Tilly, 1978). Daneben gehen Konzepte der politischen Gelegenheitsstrukturen (Eisinger, 1973), der Industrie- (King, 2008) und Unternehmensgelegenheiten (Schurman, 2004) zwar auf die Frage der günstigen Einflussmöglichkeiten von Bewegungsorganisationen ein, stellen selbst aber keine explizit strategischen Überlegungen an. Neuere Ansätze beginnen einen ausgeprägten Strategiebegriff zu entwickeln (Maney, Andrews, KutzFlamenbaum, Rohlinger \& Goodwin, 2012; Meyer \& Staggenborg, 2012), der die agency von Akteuren im Gegensatz zu deren strukturellen Beschränkungen betont und strategische Interaktionen ins Zentrum stellt (Jasper, 2004, 2012; Jasper \& Duyvendak, 2015).

Ich favorisiere einen Strategiebegriff, der sich von einem rein rationalen Verständnis abgrenzt. Letzteres begreift Strategien als rationales Wahlhandeln zur Erfolgsmaximierung in einer überschaubaren, kalkulierbaren Situation. Strategien seien demnach „,erfolgsorientierte Konstrukte, die auf situationsübergreifenden Ziel-Mittel-Umwelt-Kalkulationen beruhen“ (Raschke \& Tils, 2013, S. 127). Der erhoffte Erfolg in der Zukunft soll durch strategische Entscheidungen herbeigeführt werden (Wiesendahl, 2010, S. 21). Dieser Erfolgsorientierung wird hier als Definitionskriterium zwar zugestimmt. Doch ein enges Strategieverständnis eignet sich vor allem dazu, ein instrumentelles Kalkül im Handeln von politischen Akteuren auszumachen (Raschke \& Tils, 2013, 88) und dieses in der politischen Praxis als 
Handreichung für Politiker vorzuschlagen. Für eine empirische Strategieanalyse ist der Begriff aber zu eingeschränkt.

Strategisches Handeln wird hier als soziales und interaktives Handeln definiert. Bei dem Versuch, ihre Ziele in verschiedenen Arenen durchzusetzen, stellen sich strategisch handelnde Akteure auf ihre Adressaten, Gegenspieler, andere institutionenbildende Akteure oder Bündnispartner ein (Jasper, 2004, S. 6). An ihnen wird strategisches Handeln ausgerichtet. Auf Grundlage der bisherigen Literatur definiere ich Strategien daher als interaktive, multiple Sequenzen erfolgsorientierten Handelns im Zeitverlauf. Aus dem hier verwendeten Verständnis leite ich analytisch einen Dreiklang von Strategieelementen ab. Strategien enthalten Bemühungen, um andere zum gewünschten Handeln zu bewegen: „By strategic action, I mean simply a situation in which individuals or groups try to get others to do what they want them to" (Jasper, 2012, S. 24f). Das heißt, es lassen sich analytisch a) ausgewählte Aktionen bzw. Instrumente der strategisch handelnden Akteure benennen, die b) an einen bestimmten Adressaten gerichtet und c) mit inhaltlichen Forderungen ausgestattet sind (s. Abb. 1).

Die Bezugnahme auf einen interaktiven und dynamischen Strategiebegriff ermöglicht Forschung zu Entwicklungen im Zeitverlauf unter Berücksichtigung sich verändernder Akteurskonstellationen. Strategien konkretisieren sich in ,sequences of events“ (Maney et al., 2012, S. 171), die zur Zielerreichung beitragen. Sie sind hier nicht als stringent planbarer Ablauf konzipiert, sondern werden als Prozess verstanden und können parallele und sogar widersprüchliche Sequenzen enthalten. Das heißt weiter, sich in Aktionen, Adressaten und Forderungen manifestierende Strategien stehen in ständiger Interaktion miteinander und bedingen oder behindern sich gegenseitig - ein Zusammenhang, der insbesondere bei gemeinsamen Strategien mehrerer Akteure auftritt. Diese Interaktionsmechanismen sind daher von zentraler Bedeutung, wenn es um die Frage von dynamischer Strategieentwicklung zwischen den Bündnispartnern geht. Mechanismen sind wiederkehrende Prozesse, die spezifische Bedingungen und Ergebnisse verbinden und zeigen, wie diese durch Zwischenschritte zustande kommen (Mayntz, 2004, S. 241). Es gilt nun in der folgenden empirischen Analyse eines Gewerkschafts-NGO-Bündnisses, die Strategien und ihre Interaktionsmechanismen im Zeitverlauf zu identifizieren (s. Abbildung 1).

Abbildung 1: Analyserahmen: Interaktionistischer Strategieansatz

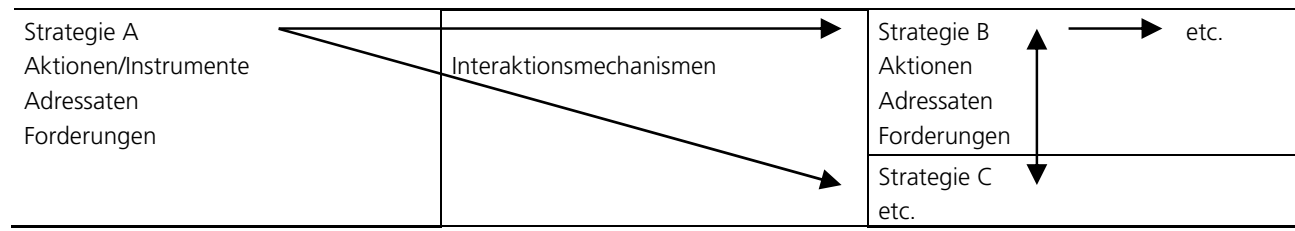

Quelle: Eigene Darstellung.

Im Folgenden werden, einer induktiven Analyse folgend, Strategien von Gewerkschaften und NGOs anhand dieses Ansatzes typologisiert und Interaktionsmechanismen benannt. Als empirische Grundlage dient dabei eine qualitative Fallstudie, die einen exemplarischen Fall mit möglichst großem Erkenntniswert untersucht. Dafür bietet sich ein besonders langfristiges Gewerkschafts-NGO-Bündnis an. Das European Banana Action Network (EURO- 
BAN), gegründet 1994 (Kryst, 2017), wird als europäisch basiertes Bündnis ausgewählt, das sich mit einer transnationalen Ausrichtung um die (Durch-)Setzung von Arbeitsstandards bemüht. EUROBAN ist ein Bündnis von Gewerkschaften und NGOs in Europa, zentrale Organisationen sind beispielsweise Banana Link, Fair Trade International oder Peuples Solidaires. Wichtige Partner sind der IUF (International Union of Food, Agricultural, Hotel, Restaurant, Catering, Tobacco and Allied Workers' Association), daneben Partnerorganisationen in den USA und Lateinamerika. EUROBAN arbeitet mit dem Fokus auf den globalen Bananenhandel und steht einer globalisierten und weitgehend unregulierten Produktionskette gegenüber.

Ziel der folgenden Fallstudie ist es, durch eine ,within-case“-Analyse (George \& Bennett, 2005, S. 19) typische Strategien zu identifizieren und Interaktionsmechanismen durch Process Tracing nachzuzeichnen (George \& Bennett, 2005, S. 12f.). Als Datengrundlage dient eine Dokumentenanalyse von öffentlichen Dokumenten, wie zum Beispiel Newslettern, Pressemitteilungen, Kampagnenmaterial oder Webseiten, sowie von internen Dokumenten, wie zum Beispiel Protokollen, Präsentationen, internen Konzeptpapieren und EMails. Ergänzend wurden acht leifadenstrukturierte Experteninterviews mit Mitgliedern des Bündnisses zwischen Oktober 2013 und Mai 2014 durchgeführt. Eine inhaltsanalytische Auswertung ermöglichte die induktive Bildung von Strategietypen, Rückschlüsse auf Voraussetzungen der einzelnen Strategieelemente, sowie die Analyse der Interaktionsmechanismen der Strategien im Zeitverlauf.

\section{Ergebnis: Strategien des Dialogs und des Aktivismus in Interaktion}

Welche Strategien entwickeln Gewerkschaften und NGOs gemeinsam in der transnationalen Governancearchitektur von Arbeit? Das folgende Kapitel widmet sich der Typologisierung unterschiedlicher strategischer Aktionen, Adressaten und Forderungen von Gewerkschaften und NGOs in der transnationalen Governancearchitektur von Arbeit, um darauffolgend Mechanismen der Strategieinteraktion in Gewerkschafts-NGO-Bündnissen zu identifizieren.

\subsection{Gewerkschafts- und NGO-Strategien: Gegensätze und Graubereiche}

Die Analyse erfolgt im Kräftefeld der Erwerbsregulierung, in dem die Aushandlung, Festlegung und Kontrolle von Arbeitsbedingungen der Erwerbstätigen stattfindet (Pries, 2008, S. 298). Innerhalb dieses Rahmens beschränke ich mich auf das öffentliche Regime, welches Handlungsnormen für eine generelle Norm- und Regelorientierung für Erwerbsarbeit beinhaltet (Pries, 2010, S. 31). Für die transnationale Erwerbsregulierung liegt eine lückenhafte Governancearchitektur vor (Koch-Baumgarten 2006, 2011). Im Gegensatz zu Regulierungen durch eine Zentralgewalt lenkt die Governanceperspektive sinnvollerweise das Augenmerk auf den „Flickenteppich“ (Koch-Baumgarten, 2006, S. 211) der minimalistischen und informellen Regulierungen, bis hin zu ,kleinen“ Koordinationsansätzen (Koch-Baumgarten, 2006, 219). In diesem politisch-institutionellen Aushandlungsprozess der Normsetzung (Bartley, 2007) positionieren sich widerstreitende Akteure mit ihren Strategien. 
Hinsichtlich der gewählten Strategien dominierten bei EUROBAN neben kontinuierlicher Kampagnenarbeit von Beginn an Lobbybemühungen. Anfang der 1990er Jahre brachte sich EUROBAN in die Debatte um ein neues Importregime für Bananen in der EU ein und forderte 1994 den bevorzugten Zugang für sozial-ökologisch produzierte Bananen (Smith, 2015, S. 63). Das Bündnis unterstützte durch Postkartenkampagnen und Lobbying das zu dieser Zeit entstehende Fairtrade-Label für Bananen zulasten alternativer Ansätze der Weltläden, wie sie von Gebana oder Oxfam bereits bestanden (Interview 10.02.2014, Paris). Insbesondere von Gewerkschaftsseite wird diese marktbasierte Lösung dauerhaft intern kritisiert, da sie nicht auf der zwingenden Einbeziehung von Gewerkschaftsrechten aufbaut, wenngleich Fairtrade nach außen von EUROBAN weiter als potentielle Lösung propagiert wird (Interview 25.03.2014, Genf; Interview 14.05.2014, Prag).

Erste Unternehmenskampagnen von EUROBAN adressierten 1997 Del Monte und 1998 Chiquita. Parallel zur Druckausübung auf multinationale Unternehmen wurden diese in Dialogformate eingebunden: 1998 richtete EUROBAN eine erste internationale Bananenkonferenz aus, 2000 ein Treffen mit den vier größten Bananenproduzenten. Folgende Verhandlungen führten 2001 schließlich zur Unterzeichnung der Internationalen Rahmenvereinbarung zwischen dem IUF und Chiquita (Riisgaard, 2004). Ende der 1990er Jahre wurden von EUROBAN erstmals Supermärkte als neue Adressaten aufgegriffen im Rahmen einer Kampagne gegen Tesco und Asda (Smith 2015, S. 89 et seq.), welche in der Folge Mitglieder der neu gegründeten Ethical Trading Initiative wurden. 2002 übte EUROBAN Druck auf das Unternehmen Noboa aus, jedoch ohne Erfolg (Frundt, 2009, S. 190). Erneuter Druck von außen trifft 2006 das Unternehmen Dole (Interview 10.02.2014, Paris). Die jüngste Make Fruit Fair-Kampagne von NGO-Bündnismitgliedern von EUROBAN adressiert große Supermärkte als verantwortliche Akteure für die Durchsetzung von Arbeitsstandards entlang der globalen Lieferkette (Interview 14.04.2014, Paris; Interview 25.03.2014, Genf).

Insbesondere Partnergewerkschaften von EUROBAN sprachen sich daneben für den Ausbau der Dialogstrategie des Bündnisses aus (Interview 25.03.2014, Genf; Interview 10.02.2014, Paris). 2005 wurde die zweite internationale Bananenkonferenz durchgeführt, auf der EUROBAN deutlich härtere Forderungen als auf der ersten stellte (Smith, 2015, S. 75). Das Bündnis brachte einen konkreten Gegenentwurf für ein Handelsregime in die Debatte ein (Parker \& Harrison, 2004) und schlug ein internationales Bananenabkommen vor, das Unternehmen auf die ILO-Kernarbeitsnormen verpflichtet (Smith, 2015, S. 121 et seqq.). EUROBAN war in der Folge maßgeblich am Aufbau des seit 2009 bestehenden World Banana Forums beteiligt, einem Dialogforum (Interview 23.10.2013 (b), Rom), das sich zum andauernden Austausch in Arbeitsgruppen von Gewerkschaften, NGOs und Unternehmen gebildet hat (Interview 23.10.2013 (b), Rom). EUROBAN versuchte zudem staatliche Akteure zu integrieren, allerdings mit nur sporadischem Erfolg (Interview 23.10.2013 (a), Rom). Das World Banana Forum fand danach 2012 und zuletzt 2017 statt.

Für eine Strategieanalyse des EUROBAN-Bündnisses werden hier als erstes Strategieelement Aktionen (Meyer \& Staggenborg, 2012, S. 8f.) beziehungsweise Instrumente (Zimmer \& Speth, 2009, S. 287) benannt. In diesen Mitteln oder Vorgehensweisen (Wiesendahl, 2010, S. 27) manifestiert sich die Art und Weise der Strategie. Im Fall von EUROBAN kann induktiv in Insider- und Outsider-Aktionen des Bündnisses unterschieden 
werden (s. Abb. 2). Als Insider-Aktionen werden dabei Aktionen kodiert, die auf Verhandlungen und beidseitige Abkommen abzielen. Empirische Beispiele von EUROBAN sind etwa Gespräche, Konferenzen oder Pilotprojekte, daneben die Beteiligung an Zertifizierung und Monitoring in Multistakeholder-Initiativen, die Verhandlungen für internationale Rahmenvereinbarungen, sowie Lobbying auf nationaler und internationaler Ebene. OutsiderAktionen hingegen sind solche Aktionen, die auf Veränderungen durch einseitige Zugeständnisse über öffentlichen Druck beziehungsweise über alternative Marktformen abzielen. Beispiele aus dem Fallbeispiel sind Kampagnen und Proteste, sowie die Unterstützung von Marktalternativen durch Buycott, dem gegenteiligen Boycott, oder Informationen über Labels wie Fairtrade. Streiks, als klassisches Gewerkschaftsinstrument, können als eine spezifische Outsider-Aktion beschrieben werden, die stets mit Verhandlungen in Zusammenhang stehen. Während Insider-Aktionen eher - aber nicht nur - durch Gewerkschaften getragen werden, die über das notwendige Netzwerk, die Machtbasis und das Selbstverständnis als Verhandlungspartner verfügen, sind Outsider-Aktionsformen das angestammte Repertoire von NGOs, die auf Skandalisierung und einer Rolle als watch dog aufbauen.

In der Theoretisierung der Ergebnisse bildet sich eine grundlegende strategische Frage gegenüber den Adressaten ab: Miteinander oder gegeneinander? (Raschke \& Tils, 2013, S. 374). Sowohl in der Gewerkschafts- als auch in der NGO-Forschung schlägt sich diese strategische Entscheidung implizit nieder. Dies ist etwa der Fall, wenn zwischen konfliktorischen und kooperativen Gewerkschaften (Bergmann, Jacobi \& Müller-Jentsch, 1975) unterschieden wird. Ebenso wird beim Ansatz des Social Movement Unionism nach strategischen Aktionen gesucht, die die Bewegungscharakteristiken von Gewerkschaften stärken (Fairbrother \& Webster, 2008, S. 211). Daneben unterscheidet die Bewegungsforschung diverse Aktionsformen und sucht nach der Ausbildung von verbandlichen Merkmalen. Es findet sich eine häufig getroffene Unterscheidung in direkte Taktiken und Lobbyismus respektive Routinepolitik (z.B. Clemens, 2005, S. 354). Die empirisch auftretenden OutsiderAktionen weisen auf die Relevanz markt-basierter Aktionen hin. Bei diesen üben Aktivisten öffentlichen Druck auf Unternehmen aus und werden bisweilen als Entrepreneurs aktiv und nehmen eine innovative Rolle im Institutionenaufbau im Markt selbst ein (Bartley, 2007, S. 310). Die Etablierung eines Nischenmarktes durch so genannte Marktbewegungen, durch Labelling- und Zertifizierungsinitiativen, bringen Druck auf Unternehmen durch den Marktmechanismus selbst (King \& Pearce, 2010).

Als weiteres Strategieelement konzeptualisiere ich Adressaten. Adressaten sind die jeweiligen Akteure, an welche sich eine Strategie richtet. Sie werden in bestimmten Arenen (Meyer \& Staggenborg, 2010, S. 8) ausgewählt (s. Tabelle 1). Bei EUROBAN werden zum einen Adressaten innerhalb der Arena der industriellen Beziehungen beziehungsweise des Tripartismus gewählt. Empirische Beispiele sind internationale Organisationen, wie die EU oder die ILO, daneben Regierungen oder Politiker im globalen Norden oder Unternehmensverbände. Auf der anderen Seite richtet EUROBAN sich über die Öffentlichkeit an Adressaten, die unter Druck gesetzt werden sollen. Adressaten in der öffentlichen Marktarena sind zum Beispiel multinationale Unternehmen, Fabriken oder Konsumenten. Daneben sind indirekt vor allem nationale staatliche Akteure mit öffentlichem Druck konfrontiert. Bei ersteren Adressierungen zeigen sich vor allem Gewerkschaften als relevante Akteure, die auf industriellen Beziehungen und einer sozialen Dialogkultur aufbauen können. Bei 
letzterer Adressierung sind es vor allem NGOs, die sich an politischen Gelegenheiten und Marktgelegenheiten orientieren.

Dieses Ergebnis bedeutet den Markt als neue Governancearena zu verstehen. Sowohl in der Verbände- als auch in der Bewegungsforschung wird der Staat häufig als primärer Adressat des Handels beschrieben, etwa im Tripartismus, durch Lobbying auf internationaler Ebene (Zimmer \& Speth, 2009), sowie beim Ansatz der politischen Gelegenheitsstruktur (Eisinger, 1973). Gewerkschaften tragen aber per se als Akteure der Selbstregulierung in der Erwerbsarbeit gemeinsam mit Unternehmen zu privaten Governanceformen bei (KochBaumgarten, 2011). Viele Forschende gehen im Zuge des Governancewandels zumindest implizit von einer staatlichen Regulierungsschwäche und einer Hinwendung zu Unternehmen aus. So machen soziale Bewegungsforscher ihre Theorien anschlussfähig für Analysen, die sich über die Arena der staatlichen Politik hinaus dem Markt zuwenden. Forschung zu Industrie- (King, 2008) oder Unternehmensgelegenheiten (Schurman, 2004) betont den Markt als neue politische Arena. Neuere Ergebnisse zeigen zudem überlappende Formen von staatlicher und nicht-staatlicher Normsetzung durch Arbeitsaktivisten auf (Fransen \& Burgoon, 2015; Kryst \& Zajak, 2017).

Schließlich beschreiben die Forderungen die inhaltliche Dimension der Strategie (Raschke \& Tils, 2013, S. 257). Als spezifische Forderungen bei EUROBAN erkenne ich konkrete, meist moderate Forderungen, die sich auf einen begrenzten Aspekt oder Raum zur Verbesserung von Arbeitsstandards in naher Zukunft beziehen (s. Tabelle 1). Beispiele sind etwa konkrete Lohnforderungen und spezifische Gewerkschaftsrechte, wie zum Beispiel Vereinigungsfreiheit, Versammlungsfreiheit und das Recht auf kollektive Verhandlungen oder andere konkrete Aspekte von Arbeitsstandards, die oftmals auf einer der ILOKernarbeitsnormen fußen. Im Gegensatz dazu kodiere ich umfassende Forderungen, welche allgemeine und weitreichende Forderungen sind, die sich auf einen grundlegenden Wandel im globalen Produktionsprozess beziehen. Diese beiden müssen sich nicht ausschließen, im Gegenteil: Spezifische Forderungen können als Etappen-, umfassende Forderungen als Langfristziele gelten. Beispiele für Letztere sind Forderungen, die auf die allgemeine Verbesserung von Arbeitsstandards hinweisen oder weitere Themen wie Umweltschutz aufnehmen. Im Resultat werden konkrete Forderungen vor allem von Gewerkschaften vertreten, die einer bottom up-Ideologie folgen und sich an Arbeitnehmerinteressen orientieren, während umfassende Forderungen durch NGOs getragen werden, die einem regulativen Ansatz der Arbeitsregulierung folgen und eher Idealen verpflichtet sind.

Grundsätzlich besteht damit hinsichtlich der Forderungen eine Unterscheidung von nicht notwendigerweise gegensätzlichen - spezifischen Zielen und weitreichenden Forderungen der strategischen Akteure (Maney et al., 2012, S. 17; Raschke \& Tils, 2013, S. 257). Dies bedeutet ein Kontinuum von Gewerkschafts- und NGO-Forschung: Für die Gewerkschaften sind meist die spezifischen Interessen von ArbeitnehmerInnen (Ford, 2009, S. 9), oft orientiert an den ILO-Kernarbeitsnormen (Ehmke, Simon \& Simon, 2009, S. 14) eine Ausgangsbasis, die über weiterreichenden Zielvorstellungen dominieren. Bei Untersuchungen zu Labour-NGOs werden neben den spezifischen Interessen ebenso radikalere oder weitreichendere Forderungen (z.B. Spooner, 2004, S. 22ff.) genannt. 
Tabelle 1: Strategien der Arbeitsregulierung in Gewerkschafts-NGO-Bündnissen

\begin{tabular}{|l|l|l|}
\hline $\begin{array}{l}\text { Strategie- } \\
\text { elemente }\end{array}$ & \multicolumn{1}{|c|}{$\begin{array}{c}\text { Strategien des transnationalen sozialen } \\
\text { bzw. tripartistischen Dialogs }\end{array}$} & Strategien des transnationalen Aktivismus \\
\hline Aktionen & In Bündnissen eher verfolgt von Gewerkschaften & \multicolumn{1}{|l|}{ In Bündnissen eher verfolgt von NGOs } \\
\hline Adressaten & $\begin{array}{l}\text { Insider-Aktionen } \\
\text { triellen Beziehungen bzw. der staatlichen Arena }\end{array}$ & $\begin{array}{l}\text { Outsider-Aktionen } \\
\text { der Marktarena }\end{array}$ \\
\hline Forderungen & Spezifische Forderungen & Umfassende Forderungen \\
\hline
\end{tabular}

Quelle: Eigene Darstellung.

Aktionen, Adressaten und Forderungen stehen in einem Zusammenhang zueinander. Im Ergebnis zeigt sich, dass auf der einen Seite Insider-Aktionen eher mit spezifischen Forderungen einhergehen und sich vor allem an Adressaten innerhalb der industriellen Beziehungen, wenn möglich auf transnationaler Ebene, beziehen. Diese Strategieelemente fügen sich zu einer hier benannten Strategie des transnationalen sozialen beziehungsweise tripartistischen Dialogs zusammen. Auf der anderen Seite werden Outsider-Aktionen eher an die Öffentlichkeit oder an Adressaten innerhalb der globalen Marktarena gerichtet und enthalten umfassendere Forderungen. Diese Zusammenhänge werden unter der hier benannten Strategie des transnationalen Aktivismus zusammengefasst. Es zeigt sich bei den Strategien von EUROBAN eine Tendenz von Gewerkschaften innerhalb der Bündnisse Strategien des transnationalen sozialen oder tripartistischen Dialogs zu verfolgen, während NGOs eher Strategien des transnationalen Aktivismus bevorzugen. Insgesamt gibt es jedoch Überschneidungen, sodass nicht immer eine eindeutige Zuordnung vorgenommen werden kann (s. Tabelle 1).

\subsection{Interaktionsmechanismen der Strategien in Gewerkschafts-NGO- Bündnissen}

Die beiden genannten Typen bilden das Kontinuum an variierenden Strategien von Gewerkschafts-NGO-Bündnissen in der transnationalen Governancearchitektur von Arbeit ab. Eine Analyse der interagierenden Strategien von Gewerkschaften und NGOs ermöglicht es, spezifische Abfolgen und Kombinationen zu identifizieren und damit Interaktionsmechanismen zu erläutern. Der Fokus dieser Analyse hebt sich damit ab von der Konzentration auf gegensätzliche oder gemeinsame Strategien von Gewerkschaften und NGOs und daraus potentiell resultierende Konflikte oder Erfolge. Reaktionen der Gegenseite, die zurück in die strategischen Entscheidungen der Akteure einfließen (Balsiger, 2015; Jasper \& Duyvendijk, 2015), sind hier nicht Gegenstand der Analyse. Ich differenziere als Ergebnis des Process Tracings bei EUROBAN induktiv insgesamt fünf Interaktionsmechanismen zwischen den beiden Strategietypen (Kryst, 2017), wovon hier beispielhaft zwei ausgeführt werden:

a) Verhandlungen durch Kampagnen: Im Laufe der Kampagnentätigkeiten von EUROBAN nutzte das Bündnis öffentlichen Druck gegen große Bananenproduzenten, wie Chiquita, Del Monte, Noboa oder Dole, um - im Sinne eines Bumerangmodells (Den Hond \& de Bakker, 2012) - zu Verbesserungen der Arbeitsbedingungen bei deren Zulieferern und Plantagen vor Ort zu gelangen. Dabei interagierten Strategien des transnationalen Aktivis- 
mus mit Strategien der transnationalen industriellen Beziehungen: EUROBAN versuchte, durch Druck auf Unternehmen von außen zu Verhandlungen und schließlich zu bindenden Abkommen zu gelangen (Tabelle 2).

Nach einer ersten Phase des Lobbyings, richteten sich Mitglieder von EUROBAN Ende der 1990er Jahre mittels koordinierter öffentlichkeitswirksamer Kampagnen an verschiedene multinationale Unternehmen in der Bananenproduktion. 1998 startete EUROBAN eine großangelegte Kampagne gegen Chiquita mit Aktivitäten in Lateinamerika und Europa. Das zu der Zeit angegriffene Markenimage von Chiquita bot sich für EUROBAN als geeignete Gelegenheit dar (Smith 2015, S. 82). EUROBAN unterstützte damit die Gewerkschaften in ihrer Verhandlungsmacht: ,the campaign would not stop so long as the company refuses to sit down with the Latin American unions“ (Smith, 2015, S. 85). Nach mehreren Verhandlungen mit dem Unternehmen führte der konstante Druck schließlich 2001 zur Unterzeichnung des ersten IFAs in der Agrarbranche durch Chiquita und den IUF (Riisgaard, 2004). Die Kampagnenarbeit und die Mobilisierung von Konsumenten war ein entscheidender Treiber für die erfolgreichen Verhandlungen (Interview 10.02.2014, Paris). Die Gewerkschaften hingegen konnten die notwendige Verhandlungslegitimität aufbringen und boten ein hilfreiches Netzwerk für die Umsetzung des Abkommens auf lokaler Ebene: „We knew [...] that we had affiliates in most of the countries where Chiquita was owning and growing bananas, that we would be able to work to actually ensure the implementation of the agreement" (Interview 25.03.2014, Genf). Hier wird deutlich, wie NGOs mit Druck von außen dazu beitragen, eine gewerkschaftliche Strategie für transnationale Kollektivverhandlungen erfolgreich umzusetzen.

Darüber hinaus adressierte das Bündnis 2006 das Unternehmen Dole. Das bestehende IFA mit Chiquita schien in dieser Zeit innerhalb des Unternehmens in Frage gestellt, und EUROBAN wollte unter anderem dieses Ergebnis nicht durch einseitigen Kampagnendruck auf einen der beiden Wettbewerber gefährden: „It is also clear that, as [...] the Agreement with COLSIBA and IUF is called into question internally within the company [Chiquita, Anm. d. Aut.] - that pressure on Chiquita's main competitor would be tactically helpful [...] It is also the most ,reactionary' of the big companies" (EUROBAN, 2003, S. 88). Dies führte zu einer Diversifikationsstrategie und einer öffentlichkeitswirksamen Kampagne gegen den Hauptkonkurrenten Dole. Ein Wechsel von Outsider- und Insider-Aktionen gegenüber Dole fand auch in diesem Fall mehrfach zeitlich eng aufeinander und kausal interagierend statt. Der Druck wurde damit industrieweit auf multiplen Angriffspunkten ausgeweitet, um zu Insider-Verhandlungsstrukturen mit Unternehmen über Arbeitsbedingungen zu gelangen.

Zusammengefasst machte der konstante Druck den Dialog mit Unternehmen erst möglich. Diese Abbildung von ,sequential patterning of tactics“ (Den Hond, de Bakker \& de Haan, 2010, S. 648) zeigt eine wiederkehrende Reihenfolge von Aktionsformen. Darüber hinaus wurde Kampagnendruck auf Wettbewerber ausgeweitet und spricht für einen industrieweiten Ansatz bei der Betrachtung von Strategien von Arbeitsaktivisten (Den Hond, de Bakker, \& de Haan, 2010). In den hier genannten Beispielen wirkten Kampagnen stets auf Verhandlungsbemühungen ein. Dieser Mechanismus, der sich teilweise über mehrere Kampagnen- und Verhandlungsrunden entfaltete, bestärkt einen dynamischen Ansatz, um diese Strategien von NGOs und Gewerkschaften in Interaktion zu erklären. 
Tabelle 2: Interaktionsmechanismus a) Verhandlungen durch Kampagnen

\begin{tabular}{|c|c|c|}
\hline Jahr & $\begin{array}{l}\text { Strategien für transnationalen sozialen } \\
\text { bzw. tripartistischen Dialog }\end{array}$ & $\rightarrow$ Strategien für transnationalen Aktivismus \\
\hline 1998 & & $\begin{array}{l}\text { Aktionen: NGO-unterstütze Kampagne gegen } \\
\text { Chiquita; } \\
\text { Adressierung: Chiquita wird auf transnationaler } \\
\text { Ebene adressiert } \\
\text { Forderungen: EUROBAN fordert Dialog des Unter- } \\
\text { nehmens mit Gewerkschaften über Arbeitsstan- } \\
\text { dards }\end{array}$ \\
\hline 2001 & $\begin{array}{l}\text { Aktionen: Verhandlungen mit bananenproduzie- } \\
\text { renden Unternehmen und Abschluss einer interna- } \\
\text { tionalen Rahmenvereinbarung mit Chiquita } \\
\text { Adressierung: IUF und Chiquita als Verhandlungs- } \\
\text { partner } \\
\text { Forderungen: spezifische Forderungen von einzel- } \\
\text { nen Arbeitsstandards sind Gegenstand der Ver- } \\
\text { handlungen }\end{array}$ & $\begin{array}{l}\text { Interaktionsmechanismus: Kampagnendruck bringt } \\
\text { Unternehmen an den Verhandlungstisch }\end{array}$ \\
\hline 2006 & $\begin{array}{l}\text { Interaktionsmechanismus: Kampagnendruck wird } \\
\text { auf einen zusätzlichen Adressaten der Industrie } \\
\text { ausgeweitet, um vorheriges Abkommen zu sichern }\end{array}$ & $\begin{array}{l}\text { Aktionen: Kampagnen gegen Dole, den } \\
\text { Hauptwettbewerber von Chiquita } \\
\text { Adressierung: Dole wird auf transnationaler Ebene } \\
\text { adressiert } \\
\text { Forderungen: allgemeine Verbesserungen der Ar- } \\
\text { beitsstandards }\end{array}$ \\
\hline
\end{tabular}

Quelle: Eigene Darstellung.

b) Verhandlungen statt Kampagnen: In umgekehrter Weise wurden bei EUROBAN im Laufe des Bündnisbestehens Verhandlungsergebnisse mit Adressaten geschützt, indem konfrontative Aktionen gegenüber diesen eingestellt wurden. Etablierte Dialoge mit Unternehmen waren bei EUROBAN nicht automatisch gefeit vor öffentlichkeitswirksamen Aktionen - im Gegenteil, der Druckaufbau war, wie gezeigt, teils inhärenter Teil der Verhandlungsstrategie. Dennoch gab es in jüngster Zeit einen anders gelagerten Interaktionsmechanismus, bei dem Strategien des transnationalen sozialen Dialogs auf Strategien des transnationalen Aktivismus des Bündnisses wirken: EUROBAN schützte den etablierten Dialog mit bananenproduzierenden Unternehmen im Rahmen des World Banana Forums und griff stattdessen Supermärkte mit der konfrontativen Make Fruit Fair-Kampagne an (Tabelle 3).

Bereits frühzeitig versuchte EUROBAN in einen langfristigen Dialog mit Produzenten $\mathrm{zu}$ treten und erreichte die Umsetzung von internationalen Bananenkonferenzen und die Etablierung des World Banana Forums im Jahr 2009. Insbesondere für Gewerkschaften und Produzenten aus dem globalen Süden zeigte sich eine Präferenz für diese Strategie des Dialogs (Interview 12.02.2014, Norwich). Es setzte sich im Bündnis die Idee durch, gemeinsam mit Unternehmen zu arbeiten: ,You change your main operation mode from one of automatic citicism to: 'Ok, let us work on the problems together.' So you become a partner in the solution, not just in raising awareness of the problem“ (Interview, 14.02.2014, Paris). Um den etablierten Dialog nicht durch öffentliche Kampagnen zu gefährden, entschied sich EUROBAN Outsider-Aktionen nicht mehr länger gegen solche Unternehmen anzuwenden, mit denen sich das Bündnis im Dialog befand. Das Risiko des Vertrauensverlustes wurde 
als zu hoch eingeschätzt: „You really think twice because you do not want to break the dialogue that you set up. So you basically do not want to really target the ones you speak to and you start to develop some relationship“ (Interview 14.05.2014, Prag).

Gleichzeitig wurden Outsider-Aktionen jedoch nicht aufgegeben; sie gehören zu den Kernaktionen von einigen Mitglieds-NGOs: ,, a lot of NGOS are at their heart campaigning organisations“ (Interview 12.03.2014, Norwich). Dies führte zu einer komplementären Neuausrichtung gegenüber neuen Adressaten. In der Folge wurden daher Großhändler beziehungsweise Supermärkte als neue Adressaten für Kampagnen des Bündnisses gewählt. Einige NGOs der Koalition starteten die Make Fruit Fair-Kampagne, die Supermärkte angreift und gleichermaßen staatliche Akteure auffordert, deren Supermarktmacht zu regulieren. Somit führten Verhandlungen zunächst zu einer Vermeidung von Kampagnen gegenüber den in Dialoge eingebundenen Unternehmen, und schlussendlich zu einem Adressatenwandel des Bündnisses.

Tabelle 3: Interaktionsmechanismus b) Verhandlungen statt Kampagnen

\begin{tabular}{|l|l|l|}
\hline Jahr & \multicolumn{1}{|c|}{$\begin{array}{c}\text { Strategien für transnationalen sozialen } \\
\text { bzw. tripartistischen Dialog }\end{array}$} & Strategien für transnationalen Aktivismus \\
\hline 2009 & $\begin{array}{l}\text { Aktionen: Dialog im World Banana Forum; } \\
\text { Adressierung: multinationale Unternehmen werden } \\
\text { als Verhandlungspartner zur Zusammenarbeit } \\
\text { adressiert } \\
\text { Forderungen: zunächst moderate Forderungen, um } \\
\text { Dialog nicht zu gefährden }\end{array}$ & \\
\hline 2011 & $\begin{array}{l}\text { Interaktionsmechanismus: Dialog wird geschützt, } \\
\text { keine Kampagnen gegen am World Banana Forum } \\
\text { beteiligte Unternehmen }\end{array}$ & $\begin{array}{l}\text { Aktionen: Kampagnen gegen Unternehmen wer- } \\
\text { den eingestellt; Kampagnen bleiben als Aktions- } \\
\text { form bestehen } \\
\text { Adressierung: Supermärkte als neue Adressaten } \\
\text { Forderungen: Skandalisierung von Arbeitsrechtsver- } \\
\text { letzungen }\end{array}$ \\
\hline
\end{tabular}

Quelle: Eigene Darstellung.

Insgesamt interagierten so vorherige Verhandlungen mit Kampagnen, die vor allem von NGOs des Bündnisses getragen werden, und richteten diese neu aus. Mit einem dynamischen Ansatz kann den verschiedenen Effekten der multiplen Mobilisierungsversuche Rechnung getragen werden (McDonnell, King \& Soule, 2015). Unternehmen reagierten auf Druck von sozialen Bewegungen, indem sie CSR-Maßnahmen in ihrem Unternehmen integrierten. Diese Maßnahmen wiederum, wie im Falle von EUROBAN deutlich zu sehen ist, „,increase a firm's receptivity to future activist challenges“ (McDonnell, King \& Soule 2015, S. 654). Dies bedeutet, je mehr die adressierten Unternehmen sich dem Dialog öffneten, umso effektiver schienen die Bemühungen des Bündnisses zu sein. Verhandlungserfolge sollten bei EUROBAN nun nicht durch weitere konfrontative Kampagnen gefährdet werden. Der folgende Adressatenwandel hatte somit nicht nur mit einer gestiegenen Macht der Supermärkte in den Industrien zu tun, sondern ging auf Grundlage etablierter Dialogstrategien vonstatten.

Abschließend lässt sich somit festhalten, dass in dem Gewerkschafts-NGO-Bündnis Strategien auf spezifische Weise interagierten. Vorherige Strategien und deren Ergebnisse 
erwiesen sich hier als neue strategische Ansatzpunkte. Durch den Interaktionsmechanismus Verhandlungen durch Kampagnen wirkten Strategien des transnationalen Aktivismus auf Strategien des transnationalen sozialen beziehungsweise tripartistischen Dialogs ein. Vice versa bildeten letztere die Ausgangsbasis für erstere durch den Mechanismus Verhandlungen statt Kampagnen. Weitere Interaktionsmechanismen des EUROBAN-Bündnisses (Kryst, 2017) sind zum einen Lobbyingstrategien, bei dem das Bündnis auf marktkonstituierenden Standards aufbaute, um Forderungen an staatliche Entscheidungsträger zu stellen. Zum anderen konnte die zunehmende Einbindung von staatlichen Akteuren in vorherige private Governancebemühungen gezeigt werden, wie sie auch bei anderen Beispielen zu sehen ist (Kryst, 2012; Fransen \& Burgoon, 2015; Kryst \& Zajak, 2017). Daneben war EUROBAN am Aufbau privater Regulierungsinitiativen beziehungsweise Multi-Stakeholder-Initiativen (Mena \& Waeger, 2014, S. 1092) beteiligt und nutzte diese als neue Gelegenheiten für nachfolgende Outsider-Aktionen im Sinne von ,,accountability politics“ (Keck \& Sikkink, 1998).

Diese Ergebnisse stärken das Argument von verschränkten Strategien der Institutionenbildung auf transnationaler Ebene. Strategische Interaktionen sind sowohl im Zeitverlauf zu erkennen als auch parallel in so genannten „trajectories of mobilization“ (Alfinito Vieira \& Quack, 2016) oder „transnational pathways“ (Zajak, 2017), die sich gegenseitig beeinflussen: ,actors situated in one trajectory picked up on the outcomes of other trajectories in order to forward their strategies and projects“ (Alfinito Vieira \& Quack 2016, S. 392). Die hier beschriebenen Mechanismen zeigen, auf welche Weise in GewerkschaftsNGO-Bündnissen vorherige Strategien zu Ausgangspunkten für neue Strategien werden.

Gewerkschaften und NGOs bringen dabei ihre spezifischen Funktionen ein. Die Unterscheidung zwischen strategischen Präferenzen von Gewerkschaften und NGOs stimmt mit jüngsten Beobachtungen einer unterschiedlichen Strategiebasis überein. Gewerkschaftliches Handeln wird auf der Basis von Arbeitnehmermobilisierung charakterisiert, während NGOs die Mobilisierung von Konsumenten für ihre Aktionen favorisieren (Egels-Zandén, Lindberg \& Hyllman, 2015, S. 350f.). Diese Beobachtung endet jedoch nicht notwendigerweise im Konflikt. Zum Beispiel können Gewerkschaften - zumindest für eine gewisse Zeit damit einverstanden sein, gemäß einer NGO-Strategie zu agieren oder eine passive Rolle in Bündnissen einzunehmen (Egels-Zandén, Lindberg \& Hyllman 2015, S. 354). Das hier aufgeführte Beispiel zeigt darüber hinaus, wie Strategieinteraktionen zu zeitlich parallelen oder kausal bedingten Kombinationen der beiden Strategietypen führen. Strategien von Gewerkschaften und NGOs interagieren gewinnbringend in Bündnissen.

\section{Fazit}

Innerhalb von Gewerkschafts-NGO-Bündnissen interagieren Strategien in der globalen Governancearchitektur von Arbeit. Aufbauend auf einem Analyserahmen von Aktionen, Adressaten und Forderungen, arbeite ich auf der einen Seite Strategien des transnationalen sozialen beziehungsweise tripartistischen Dialog heraus, die auf Insider-Aktionen bauen und staatliche Adressaten sowie Unternehmen in den industriellen Beziehungen mit spezifischen Forderungen konfrontierten. Auf der anderen Seite werden Strategien des transnationalen Aktivismus benannt, die Outsider-Aktionen verwenden, um über die Öffentlichkeit 
oder Marktakteure weitreichende Forderungen für private Governance von Arbeit zu stellen. Gewerkschaften bevorzugen ursprünglich erstere Strategien, während NGOs letztere favorisieren. Doch trotz der spezifischen Präferenzen, die die Akteursgruppen einbringen, sind Graubereiche und gegenseitige Unterstützungen sichtbar. Durch die Darstellung eines langanhaltenden Bündnisses kann gezeigt werden, wie über die Zeit Strategien auf transnationaler Ebene kombiniert werden. Ich identifiziere dabei beispielhaft zwei Interaktionsmechanismen, die strategische Entwicklungen im Zeitverlauf abbilden: Verhandlungen durch Kampagnen und Verhandlungen statt Kampagnen.

Mit diesen Ergebnissen trage ich zur Forschung von Gewerkschafts-NGO-Bündnissen bei. Während Kooperationen von Gewerkschaften und NGOs eine gegenseitige Unterstützung nahelegen, konzentrieren sich bisherige Arbeiten meist auf die Phase der Bündnisbildung. Nur wenige Ausnahmen untersuchen gemeinsame Strategieentwicklungen - seien es konfliktreiche (Ford, 2009; Egels-Zandén, Lindberg \& Hyllman, 2015) oder erfolgreiche (Kryst, 2012). Meine Ergebnisse verweisen auf distinktive Strategien von Gewerkschaften und NGOs, wobei jedoch Überlappungen und vor allem interagierende Strategien empirisch evident sind. Dies bedeutet, dass Gewerkschaften und NGOs an ihren originär strategischen Präferenzen festhalten können und sich nicht zwingend auf eine gemeinsame Strategie einigen müssen, sondern - im Gegenteil - ihre unterschiedlichen Strategien sich kausal bedingen. Im vorliegenden Beitrag wurde ein langanhaltendes Bündnis auf seine Strategieinteraktionen hin untersucht. Inwiefern gegenteilige Mechanismen bei nicht komplementären Strategien vorhanden sind, bedarf der Untersuchung weiterer Fallbeispiele. Ähnliche Mechanismen, wie die hier identifizierten, könnten zudem bei reinen NGO- oder reinen Gewerkschaftsbündnissen auftreten. Weitere Forschung müsste hier die Strategiebedingungen, die Gewerkschaften und NGOs mit spezifischen Funktionen in Bündnissen ausstatten, weiter konkretisieren.

Daneben verweist dieser Beitrag auf Forschung zu öffentlicher und privater Governance in der Arbeitsregulierung. Bei der Übersetzung des interaktionistischen Strategiebegriffs in das Feld der Arbeitsregulierung ist es notwendig, neue Formen der privaten Governance in das Handlungsspektrum von Gewerkschaften und NGOs zu integrieren. Dies ist hier in der Form von markt-konstituierenden Aktionsformen als eine Outsider-Aktion geschehen, sowie in der Benennung der Marktsphäre als neue politische Arena. Eine klare Abgrenzung von staatlicher gegenüber privater Governancestrategie wird des Weiteren als zu überspitzt abgelehnt, da es zu kombinierten Formen von öffentlicher und privater Governance durch nichtstaatliche Akteure kommt (Fransen \& Burgoon, 2015; Kryst \& Zajak, 2017).

Zuletzt trägt diese Studie zur Weiterentwicklung eines strategisch-interaktionistischen Ansatzes nicht nur in der Governancearchitektur von Arbeit bei (Jasper, 2004; den Hond, Stolwijk \& Merk, 2014). Strategien sind im politischen Raum omnipräsent. Ob es um Kampagnen von NGOs oder um Verhandlungen von Gewerkschaften mit Arbeitgeberverbänden geht: Die politischen Akteure stellen mittels ausgewählter Aktionen ihre Forderungen an bestimmte Adressaten, um deren Handeln zukünftig zu beeinflussen. Oder anders: Sie versuchen ihr Gegenüber zum gewünschten Handeln zu bewegen. Sie agieren strategisch. Jüngste Forschung betont die Notwendigkeit, dynamische Interaktionen mit in Betracht zu ziehen, um ein umfassenderes Bild von Arbeitsaktivisten in der globalen Arbeitsregulierung zu geben (Den Hond, de Bakker \& de Haan 2010, S. 653; McDonnell, King \& 
Soule 2015, S. 672). Ein interaktiver Strategieansatz analysiert kausale und dynamische Zusammenhänge der Strategieentwicklung und zielte hier auf eine Beschreibung der Interaktionsmechanismen zwischen Strategien von Gewerkschaften und NGOs ab.

\section{Literatur}

Abendroth, W. (1969). Sozialgeschichte der europäischen Arbeiterbewegung. 5. Aufl. Frankfurt/Main: Suhrkamp.

Alfinito Vieira, A. C., \& Quack, S. (2016). Trajectories of Transnational Mobilization for Indigenous Rights in Brazil. Revista de Administração de Empresas, 46 (4), 380-394. doi: 10.1590/S0034-759020160403

Anner, M. \& Evans, P. (2004). Building Bridges across a Double Divide: Alliances between US and Latin American Labour and NGOs. Development in Practice, 14, 34-47. doi: 10.1080/0961452032000170613

Arenas, D., Lozano, J. M. \& Albreda, L. (2009). The Role of NGOs in CSR: Mutual Perceptions among Stakeholders. Journal of Business Ethics, 88, 175-197. doi: 10.1007/s10551-009-0109-x

Avdagić, S. \& Crouch, C. (2006). Organized Economic Interests: Diversity and Change in an Enlarged Europe. In P. Heywood, E. Jones, M. Rhodes \& U. Sedelmeier (Hrsg.), Developments in European Politics (S. 196-215). Houndmills: Palgrave Macmillan.

Baccaro, L., Hamann, K. \& Turner, L. (2003). The Politics of Labour Movement Revitalization: The Need for a Revitalized Perspective. European Journal of Industrial Relations 9 (1), 119-133. doi: $10.1177 / 0959680103009001455$

Balsiger, P. (2015). Managing Protest: The Political Action Repertoires of Corporations. In D. Della Porta \& M. Diani (Hrsg.), The Oxford Handbook of Social Movements (S. 653-665). Oxford: Oxford University Press.

Bartley, T. (2007). Institutional Emergence in an Era of Globalization: The Rise of Transnational Private Regulation of Labour and Environmental Conditions. American Journal of Sociology, 113 (2), 297-351. doi: 10.1086/518871

Bergmann, J., Jacobi, O. \& Müller-Jentsch, W. (1975). Gewerkschaften in der Bundesrepublik. Gewerkschaftliche Lohnpolitik zwischen Mitgliederinteressen und ökonomischen Sachzwängen. Frankfurt: Europäische Verlagsanstalt.

Braun, R. \& Gearhart, J. (2004). Who Should Code your Conduct? Trade Union and NGO Differences in the Fight for Workers' Rights. Development in Practice, 14, 183-196. doi: 10.1080/0961452032000170758

Bronfenbrenner, K. (Hrsg.) (2007). Global Unions: Challenging Transnational Capital Through Cross-Border-Campaigns. Ithaca: Cornell University Press.

Brookes, M. (2013). Varieties of Power in Transnational Labor Alliances. An Analysis of Workers' Structural, Institutional, and Coalitional Power in the Global Economy. Labor Studies Journal, 38 (3), 181-200. doi: 10.1177/0160449X13500147

Clemens, E. (2005). Two Kinds of Stuff. The Current Encounter of Social Movements and Organisations. In G. F. Davis (Hrsg.), Social Movements and Organization Theory (S. 351-366). Cambridge: Cambridge University Press. doi: 10.1017/CBO9780511791000.018

Cohen, L. \& Rai, S. (2000). Global Social Movements. Towards a Cosmopolitan Politics. In R. Cohen, \& S. Rai (Hrsg.), Global Social Movements, (S. 1-17). London: Athlone Press.

Compa, L. (2004). Trade unions, NGOs, and corporate codes of conduct. Development in Practice, 14 (1/2), 210-215. doi: 10.1080/0961452032000170776

Della Porta, D. (2006). Form Corporatist Unions to Protest Unions? On the (difficult) Relations between Organized Labour and new Social Movements. In C. Crouch \& W. Streeck (Hrsg.), The 
Diversity of Democracy. Corporatism, Social Order and Political Conflict (S. 71-97). Cheltenham: Edward Elgar.

Den Hond, F. \& de Bakker, F. (2012): Boomerang politics: how transnational stakeholders impact multinational corporations in the context of globalization. In A. Lindgreen, P. Kotler, J. Vanhamme \& F. Maon (Hrsg.), A Stakeholder Approach to Corporate Social Responsibility: Pressures, Conflicts, Reconciliation (S. 275-292). Aldershot: Gower.

Den Hond, F., de Bakker, D. \& de Haan, P. (2010). The Sequential Patterning of Tactics. Activism in the Global Sports Apparel Industry, 1988-2002. International Journal of Sociology and Social Policy, 30 (11/12), 648-665. doi: 10.1108/01443331011085240

Den Hond, F., Stolwijk, S. \& Merk, J. (2014). A strategic-interaction analysis of an Urgent Appeal System and its outcomes for garment workers. Mobilization: An International Quaterly, 19 (1), 83-111.

Eisinger, P. K. (1973). The Conditions of Protest Behavior in American Cities. American Political Science Review, 67 (1), 11-28. doi: 10.2307/1958525

Egels-Zandén, N. \& Hyllman, P. (2011). Differences in Organizing between Unions and NGOs: Conflict and Cooperation among Swedish Unions and NGOs. Journal of Business Ethics, 101, 249261. doi: 10.1007/s10551-010-0720-x

Egels-Zandén, N., Lindberg, K. \& Hyllman, P. (2015). Multiple Institutional Logics in Union-NGO Relations: Private Labor Regulation in the Swedish Clean Clothes Campaign. Business Ethics: A European Review, 24 (4), 347-360. doi: 10.1111/beer.12091

Ehmke, E., Simon, A. \& Simon, J. (2009). Internationale Arbeitsstandards im globalen Kapitalismus. In E. Ehmke, A. Simon \& J. Simon (Hrsg.), Internationale Arbeitsstandards in einer globalisierten Welt (S. 12-42). Wiesbaden: VS-Verlag für Sozialwissenschaften.

EUROBAN (2003). Minutes of EUROBAN Meeting, Part II. Montreuil/France, 11.-12. Dezember 2003.

Evans, P. (2010). Is it Labor's Turn to Globalize? Twenty-first Century Opportunities and Strategic Responses. Global Labour Journal, 20, 352-379. doi: 10.15173/glj.v1i3.1082

Fairbrother, P. \& Webster, E. (2008). Social Movement Unionism: Questions and Possibilities. Employee Responsibilities and Rights Journal, 20 (4), 309-313. doi: 10.1007/s10672-008-9091-1

Fichter, M., Gester, J. \& Zeuner, B. (2004). Zukunft der Gewerkschaften. Externe Herausforderungen - Interne Problemlagen - Zukunftsoptionen: Eine internationale Perspektive. Arbeitspapier Hans-Böckler-Stiftung, 44 (Teil II), 113-186.

Ford, M. (2009). Workers and Intellectuals. NGOs, Trade Unions and the Indonesian Labour Movement. Singapore: NUS Press.

Fransen, L. \& Burgoon, B. (2015). Global Labour-Standards Advocacy by European Civil Society Organizations: Trends and Developments. British Journal of Industrial Relations, 53, 204-230. doi: 10.1111/bjir.12017

Frege, C. M. \& Kelly, J. (2003). Union Revitalization Strategies in Comparative Perspective. European Journal of Industrial Relations, 9, 7-24. doi: 10.1177/095968010391002

Frundt, Henry J. (2009). Fair Bananas. Famers, Workers, and Consumers Strive to Change an Industry. Tucson, AZ: University of Arizona Press.

Gallin, D. (2000). Trade Unions and NGOs: A Necessary Partnership for Social Development. United Nations Research Institute for Social Development: Civil Society and Social Movement Program, 1.

George, A. L. \& Bennett, A. (2005). Case Studies and Theory Development in the Social Sciences. Cambridge: MIT Press.

Glaab, M. (2008). Analyse: ,Leadership matters` - auch und gerade in Strategiefragen. Forschungsjournal Neue Soziale Bewegungen, 21 (1), 97-101. 
Hassel, A. (2008). The Evolution of a Global Labor Governance Regime. Governance: An International Journal of Policy, Administration, and Institutions, 21 (2), 231-251.

doi: 10.1111/j.1468-0491.2008.00397.x

Heins, V. (2002). Weltbürger und Lokalpatrioten: Eine Einführung in das Thema Nichtregierungsorganisationen. Opladen: Leske + Budrich. doi: 10.1007/978-3-663-11827-5

Janett, D. (1997). Vielfalt als Strategievorteil: Zur Handlungskompetenz von Nicht-Regierungsorganisationen in komplexen Umwelten. In E. Altvater, A. Brunnengräber, M. Haake \& H. Walk (Hrsg.), Vernetzt und verstrickt. Nicht-Regierungs-Organisationen als gesellschaftliche Produktivkraft (S. 146-173). Münster: Westfälisches Dampfboot.

Jasper, J. M. (2004). A Strategic Approach to Collective Action: Looking for Agency in Social Movement Choices. Mobilization, 9, 1-13.

Jasper, J. M. (2012). Choice Points, Emotional Batteries, and Other Ways to Find Strategic Agency at the Microlevel. In G. M. Maney, R. V. Kutz-Flamenbaum, D. A. Rohlinger \& J. Godwin (Hrsg.), Strategies for Social Change (S. 23-42). Minneapolis, London: University of Minnesota Press. https://doi.org/10.5749/minnesota/9780816672899.003.0002

Jasper, J. M. \& Duyvendak, J. W. (Hrsg.) (2015). Players and Arenas: The Interactive Dynamics of Protest. Amsterdam: Amsterdam University Press.

Keck, M. E. \& Sikkink, K. (1998). Activists beyond Boarders: Advocacy Networks in International Politics. Ithaca, New York: Cornell University Press.

King, B. G. (2008). A Social Movement Perspective of the Stakeholder Collective Action and Influence. Business and Society, 47, 21-49. doi: 10.1177/0007650307306636

King, B. G. \& Pearce, N. A. (2010). The Contentiousness of Markets: Politics, Social Movements, and Institutional Change in Markets. Annual Review of Sociology, 35 (1), 249-267. doi: 10.1146/annurev.soc.012809.102606

Klein, A., Walk, H. \& Brunnengräber, A. (2005). Mobile Herausforderer und alternative Eliten. NGOs als Hoffnungsträger einer demokratischen Globalisierung? In A. Brunnengräber, A. Klein \& H. Walk (Hrsg.), NGOs im Prozess der Globalisierung. Mächtige Zwerge - umstrittene Riesen (S. 10-77). Wiesbaden: VS-Verlag. doi: 10.1007/978-3-322-80983-4_2

Koch-Baumgarten, S. (1999). Gewerkschaftsinternationalismus und die Herausforderung der Globalisierung. Das Beispiel der Internationalen Transportarbeiterföderation (ITF). Frankfurt/Main: Campus Verlag.

Koch-Baumgarten, S. (2006). Globale Gewerkschaften und Industrielle Beziehungen in der Global Governance. Industrielle Beziehungen, 13 (3), 205-222.

Koch-Baumgarten, S. (2011). Gewerkschaften und global governance: Grenzen und Möglichkeiten einer grenzüberschreitenden Regulierung von Erwerbsarbeit. Internationale Politik und Gesellschaft, 2, 51-68.

Koch-Baumgarten, S., \& Kryst, M. (2015). Trade unions and Collective Bargaining Power in Global Governance. In A. Marx, J. Wouters, G. Rayp \& L. Beke (Hrsg.), Global Governance of Labour Rights. Assessing the Effectiveness of Transnational Public and Private Policy Initiatives (S. 150-169). Cheltenham, Northhampton: Edward Elgar. doi: 10.4337/9781784711467.00013

Krüger, S. (2002). Nachhaltigkeit als Kooperationsimpuls. Sozial-ökologische Bündnisse zwischen NGOs und Gewerkschaften. Münster: Westfälisches Dampfboot.

Kryst, M. (2012). Coalitions of Labor Unions and NGOs: The Room of Maneuver of the German Clean Clothes Campaign. Interface: A Journal for and about Social Movements, 4 (2), 101-129.

Kryst, M. (2017). Transnationale Bündnisse von Gewerkschaften und NGOs: Eine interaktionistische Strategieanalyse. Dissertation Philipps-Universität Marburg, unveröffentlicht.

Kryst, M. \& Zajak, S. (2017). Mehr Staat durch Markt? Adressierungsstrategien der Anti-SweatshopBewegung in Europa. In P. Daphi, N. Deitelhoff, D. Rucht, D. \& S. Teune (Hrsg.): Protest in 
Bewegung? Zum Wandel von Bedingungen, Formen und Effekten politischen Protests. Sonderband: Leviathan. Baden-Baden: Nomos, S. 63-92.

doi: 10.5771/9783845288413-62

Maney, G. M., Andrews, K. T., Kutz-Flamenbaum, R. V., Rohlinger, D. A., \& Goodwin, J. (2012). An Introduction to Strategies for Social Change. In G. M. Maney, R. V. Kutz-Flamenbaum, D. A. Rohlinger \& J. Goodwin (Eds.), Strategies for Social Change (pp. xi-xxxviii). Minnesota: University of Minnesota Press. doi: 10.5749/minnesota/9780816672899.001.0001

Mayer, B. (2009). Cross-Movement Coalition Formation: Bridging the Labor-Environment Divide. Sociological Inquiry, 79 (2), 219-239. doi: 10.1111/j.1475-682X.2009.00286.x

Mayntz, R. (2004). Mechanisms in the Analysis of Social Macro-Phenomena. Philosophy of the Social Sciences, 34 (2), 237-259. doi: 10.1177/0048393103262552

McDonnell, M.-H., King, B. G. \& Soule, S. (2015). A Dynamic Process Model of Private Politics: Activists Targeting and Corporate Receptivity to Social Challenges. American Sociological Review, 80 (3), 648-678. doi: 10.1177/0003122415581335

Mena, S. \& Waeger, D. (2014). Activism for Corporate Responsibility: Conceptualizing Private Regulation Opportunity Structures. Journal of Management Studies, 36, 249-267. doi: doi.org/10.1111/joms.12092

Meyer, D. S. \& Staggenborg, S. (2012). Thinking about Strategy. In G. M. Maney, R. V. Kutz-Flamenbaum, D. A. Rohlinger \& J. Goodwin (Hrsg.), Strategies for Social Change (S. 3-22). Minnesota: University of Minnesota Press. doi: 10.5749/minnesota/9780816672899.003.0001

Müller, T., Platzer, H.-W. \& Rüb, S. (2010). Transnational company policy and coordination of collective bargaining - new challenges and roles for European industry federations. In: Transfer, 16 (4), 509-524. doi: 10.1177/1024258910383083

Müller-Jentsch, W. (2008). Arbeit und Bürgerstatus. Studien zur sozialen und industriellen Demokratie. Wiesbaden: VS-Verlag.

Münkler, H. (2010). Zum Verhältnis von politischer und militärischer Strategie. In J. Raschke \& R. Tils (Hrsg.), Strategie in der Politikwissenschaft. Konturen eines neuen Forschungsgebiets (S. 45-73). Wiesbaden: VS Springer. doi: 10.1007/978-3-531-92209-6_3

Parker, L. \& Harrison, J. on behalf of EUROBAN (2004). Alternative Trade Policy Proposal: Differentiated Tariffs.

Pries, L. (2008). Die Transnationalisierung der sozialen Welt. Frankfurt/Main: Suhrkamp.

Pries, L. (2010). Erwerbsregulierung in einer globalisierten Welt. Wiesbaden: VS-Verlag. doi: 10.1007/978-3-531-91956-0

Raschke, J. \& Tils, R. (2013). Politische Strategie. Eine Grundlegung. 2. Aufl. Wiesbaden: VSVerlag. doi: 10.1007/978-3-531-19871-2

Rehder, B. (2008). Revitalisierung der Gewerkschaften? Die Grundlagen amerikanischer Organisierungserfolge und ihre Übertragbarkeit auf deutsche Verhältnisse. Berliner Journal für Soziologie, 18 (3), 432-456. doi: 10.1007/s11609-008-0029-0

Reutter, W. \& Rütters, P. (2003). Internationale und europäische Gewerkschaftsorganisationen: Geschichte, Struktur und Einfluss. In W. Schroeder \& B. Weßels (Hrsg.), Die Gewerkschaften in Politik und Gesellschaft der Bundesrepublik Deutschland (S. 512-542). Wiesbaden: Westdeutscher Verlag.

Riisgaard, L. (2004). The IUF/COLSIBA - CHIQUITA framework agreement: a case study. Multinational Enterprises Programme Working Paper No. 94.

Roth, R. (2005). Transnationale Demokratie. Beiträge, Möglichkeiten und Grenzen von NGOs. In A. Brunnengräber, A. Klein \& H. Walk (Hrsg.), NGOs im Prozess der Globalisierung. Mächtige Zwerge - umstrittene Riesen (S. 80-128). Wiesbaden: VS-Verlag.

doi: 10.1007/978-3-322-80983-4_3 
Sabatier, P. A. (1998). The Advocacy Coalition Framework: Revisions and Relevance for Europe. Journal of European Public Policy, 5, 98-130. doi: 10.1080/13501768880000051

Saretzki, T. (2010). Strategie als Herausforderung für die deliberative Demokratietheorie. In J. Raschke, \& R. Tils (Hrsg.), Strategie in der Politikwissenschaft. Konturen eines neuen Forschungsfeldes (S. 121-150). Wiesbaden: VS-Verlag. doi: 10.1007/978-3-531-92209-6_6

Scherrer, C. (2002). Von den NGOs lernen? Wie Gewerkschaften den Prozess der Globalisierung beeinflussen können. In C. Flavin, B. Young, C. Scherrer \& K. Zwickel (Hrsg.), Global Governance. Gewerkschaften und NGOs - Akteure für Gerechtigkeit und Solidarität (S. 116-128). Hamburg: VSA-Verlag.

Schmitt-Beck, R. (2008). Professionalisierte Kommunikation. Acht Thesen zum Verhältnis von politischer Strategie und Öffentlichkeit. Forschungsjournal Neue Soziale Bewegungen, 21 (1), 71 73.

Schroeder, W. (2009). Gewerkschaften in drei Welten. Ein Überblick. Forschungsjournal Neue Soziale Bewegungen, 4, 13-22. doi: 10.1515/fjsb-2009-0404

Schroeder, W. (2014). Handbuch Gewerkschaften in Deutschland. Wiesbaden: Springer VS. doi: org/10.1007/978-3-531-19496-7

Schurman, R. (2004). Fighting "Frankenfoods": Industry Opportunity Structures and the Efficacy of the Anti-Biotech Movement in Western Europe. Social Problems, 51 (2), 243-268. doi: org/10.1525/sp.2004.51.2.243

Schwarz, C. (2008). Analyse: Strategic Studies als akademische Disziplin. Forschungsjournal Neue Soziale Bewegungen, 21 (1), 101-107.

Smith, A. (2015): The Banana Saga: Towards fair and sustainable product chains. Unpublished.

Spooner, D. (2004). Trade Unions and NGOs: The Need for Cooperation. Development in Practice, 14, 19-33. doi: org/10.1080/0961452032000170604

Streeck, W. (1996). Industrielle Beziehungen in einer institutionalisierten Wirtschaft. In U. Beck (Hrsg.), Politik der Globalisierung (S. 169-202). Frankfurt/Main: Suhrkamp.

Streek, W. \& Rehder, B. (2005). Institutionen im Wandel: Hat die Tarifautonomie eine Zukunft? In H. W. Busch, H. P. Frey, M. Hüther, B. Rehder \& W. Streeck (Hrsg.), Tarifpolitik im Umbruch (S. 49-82). Köln: Deutscher Institutsverlag.

Tilly, C. (1978). From Mobilization to Revolution. Reading, MA: Addison-Wesley.

Van Dyke, N. \& McCammon, H. J. (Hrsg.) (2010). Strategic Alliances. Coalition Building and Social Movements. Minneapolis: University of Minnesota Press.

Wiesendahl, E. (2010). Rationalitätsgrenzen politischer Strategie. In J. Raschke \& R. Tils (Hrsg.), Strategie in der Politikwissenschaft. Konturen eines neuen Forschungsfeldes (S. 21-44). Wiesbaden: VS-Verlag. doi: org/10.1007/978-3-531-92209-6_2

Zajak, S. (2017). Transnational Activism, Global Labor Governance, and China. New York: Palgrave Macmillan. doi: org/10.1057/978-1-349-95022-5

Zimmer, A. \& Speth, R. (2009). Verbändeforschung. In V. Kaina \& A. Römmele (Hrsg.), Politische Soziologie. Ein Studienbuch (S. 267-309). Wiesbaden: Springer VS.

doi: org/10.1007/978-3-531-91422-0_11 


\section{Oliver Thünken*}

\section{Bewegung im Betrieb. Organizing-Projekte und die Revitalisierung der industriellen Beziehungen ${ }^{* *}$}

\section{Zusammenfassung}

Der Beitrag argumentiert, dass gewerkschaftliche Organisierung im Rahmen von betrieblichen Organizing-Projekten den Charakter von sozialen Bewegungen annimmt und damit die Verfasstheit der industriellen Beziehungen in Deutschland herausfordert. Während das duale System der Interessenvertretung repräsentative, auf Ausgleich und Kompromiss angelegte und zudem stark verrechtlichte Verhandlungssysteme etabliert, werden im Rahmen von Organizing-Prozessen die Beschäftigten selbst zur aktiven Gestaltung der Interessenpolitik im Betrieb motiviert. Dabei kommt es zu einer bemerkenswerten beteiligungsorientierten Erweiterung des dualen Systems auf betrieblicher Ebene, mit der auch Potenziale für die Revitalisierung der industriellen Beziehungen verbunden sind.

Schlagwörter: Beteiligung, Betriebsräte, Duales System der Interessenvertretung, Gewerkschaften, gewerkschaftliche Erneuerung, Industrielle Beziehungen, Soziale Bewegungen

\section{Social movement unionism at the shop floor. Organizing and the revitalization of industrial relations}

\section{Abstract}

The article argues that union organizing within corporate organizing projects takes on the character of social movements and thus represents a challenge for the constitutional nature of German industrial relations. Whilst the German system establishes representative bargaining systems, based on compensation and compromise as well as strong legalization, the organizing processes in contrast motivates employees to shape actively their policy interests at the company level. This results in a noteworthy participation-oriented expansion of the dual system at the workplace, which in turn has the potential for revitalizing industrial relations (institutions).

Key Words: organizing, work council, union, participation, German industrial relations, social movement unionism (JEL: J52, J53)

\footnotetext{
* Dipl.-Soz.-Wiss. Oliver Thünken, Technische Universität Chemnitz, Institut für Soziologie, Thüringer Weg 9,09126 Chemnitz. E-Mail: oliver.thuenken@soziologie.tu-chemnitz.de

** Artikel eingegangen: 31.8.2017, revidierte Fassung akzeptiert nach doppelt-blindem Begutachtungsverfahren: 16.3 .2018
} 
Nachdem die Diskussion um gewerkschaftliches Organizing zum Ende der 2000er Jahre einen Höhepunkt in Deutschland erreicht hatte und immer mehr DGB-Gewerkschaften Organizing-Projekte auflegten oder Organizing-Module in ihre Schulungsprogramme aufnahmen, ist es um die gewerkschaftliche Erneuerungsstrategie zwischenzeitlich stiller geworden. Hatte Organizing zunächst noch polarisiert, weil damit sowohl weitreichende Hoffnungen auf eine Wiedererstarkung der Gewerkschaftsbewegung als auch Ängste und Befürchtungen verbunden waren, scheint sich mittlerweile eine Beruhigung abzuzeichnen. Auf Seiten der Hoffnungsvollen hat sich eine gewisse Ernüchterung eingestellt. Und von Seiten der Mahner und Kritiker, die mit Organizing die sozialpartnerschaftliche Prägung der Arbeitsbeziehungen bedroht sehen, wird auch deutlich zurückhaltender argumentiert. Dieses Auslaufen der Debatte kann möglicherweise damit erklärt werden, dass die Implementierung von Organizing-Elementen doch weit reibungsloser vonstattengegangen ist, als es seinerzeit allenthalben erwartet wurde. Für die wissenschaftliche Diskussion muss allerdings zunächst konstatiert werden, dass es schlicht an öffentlich zugänglichen Untersuchungen fehlt, die sich Organizing-Projekten widmen und somit die empirische Basis für eine entsprechende Debatte eröffnen würden.

Gerade vor dem Hintergrund dieser empirischen Lücke lohnt ein Blick in die Forschungsergebnisse, die im Rahmen eines Dissertationsprojektes erarbeitet wurden und hier im Folgenden vor dem Hintergrund des Bewegungscharakters von Organizing-Prozessen vorgestellt und kontextualisiert werden sollen. Zu diesem Zweck wird zunächst der Organizing-Ansatz unter besonderer Berücksichtigung seines Bewegungscharakters rekonstruiert. Darauf folgt eine Bestimmung der grundlegenden Charakteristika des dualen Systems der Interessenvertretung, um diese schließlich mit dem Organizing-Ansatz zu kontrastieren und entsprechende Spannungsmomente identifizieren zu können. Auf Grundlage dieser begrifflichen Bestimmungen werden anschließend zentrale Ergebnisse der empirischen Untersuchung eines überregional durchgeführten Organizing-Projekts der IG Metall in der Windindustrie vorgestellt. Auf dieser Grundlage soll der Frage nachgegangen werden, wie Organizing-Prozesse, bei denen die Beschäftigten zur aktiven Gestaltung der Interessenpolitik und Selbsttätigkeit motiviert werden, im Kontext des stark durch Interessenrepräsentation geprägten dualen Systems der Interessenvertretung wirken. Entgegen der Einschätzung, dass der Organizing-Ansatz und das duale System aufgrund ihrer unterschiedlichen Prägung kaum miteinander vereinbar sind, wird im Folgenden die These entwickelt, dass es über die im Rahmen von Organizing-Prozessen aufgebauten Aktivenkreise zu einer beteiligungsorientierten Erweiterung der betrieblichen Interessenvertretung kommt. Über den Bewegungscharakter des Organizing, der sich in der Beteiligung und Mobilisierung der Beschäftigten ausdrückt, werden Legitimität und Vertretungswirksamkeit der Betriebsräte gestärkt, so dass eine Revitalisierung der betrieblichen Interessenvertretung konstatiert werden kann.

\section{Theoretische Grundlagen}

Die folgenden Ausführungen geben einen Überblick zum Stand der Diskussion um gewerkschaftliches Organizing. Dabei werden die internationale Forschungsdebatte der Labor Revitalization Studies (LRS) aufgenommen und wichtige Ergebnisse und theoretische Ansätze 
eingeführt. Dem folgen eine Skizze des dualen Systems der Interessenvertretung und schließlich ein Abriss der Organizing-Debatte in Deutschland.

\subsection{Organizing-Begriff}

Ausgangspunkt für die Beschäftigung mit dem Organizing-Ansatz ist die gewerkschaftliche Krise, die sich insbesondere in sinkenden Mitgliederzahlen und einer damit einhergehenden schwindenden Durchsetzungsfähigkeit der Gewerkschaften ausdrückt (Ebbinghaus \& Göbel, 2014). Unter dem Stichwort Organizing werden spätestens seit den 2000er Jahren auch in Deutschland Fragen der gewerkschaftlichen Erneuerung diskutiert (Hälker \& Vellay, 2007; Bremme, Fürniß \& Meinecke, 2007; Brinkmann et al., 2008; Haipeter \& Dörre, 2011; Schmalz \& Dörre, 2013; Wetzel, 2013; Kocsis, Sterkel \& Wiedemuth, 2013).

Die Organizing-Debatte begann in den USA bereits zum Ende der 1980er Jahre und führte dazu, dass das sogenannte Service-Modell, an dem sich die Mehrheit der US-amerikanischen Gewerkschaften orientierte, durch den alternativen Organizing-Ansatz unter Druck gesetzt wurde (Voss \& Sherman, 2000, S. 310-314; Gumbrell-McCormick \& Hyman, 2014, S. 55-56). Während die traditionelle Gewerkschaftsarbeit im Sinne des Service-Modells die Mitglieder weitgehend als Kundschaft betrachtet und sich auf die Verwaltung der bestehenden Mitglieder konzentriert, setzt das Organizing-Modell auf die Erweiterung des gewerkschaftlichen Organisationsbereiches durch die Erschließung von nicht organisierten Branchen und Beschäftigtengruppen. Ein Teil der US-amerikanischen Gewerkschaftsbewegung identifizierte - ganz im Sinne des Organizing-Modells - zum Ende der 1990er Jahre die Mitgliederfrage als die entscheidende Aufgabe, der sich die Gewerkschaften stellen müssten (Brinkmann et al., 2008, S. 51-56). Bekanntestes Beispiel für eine Gewerkschaft, die sich neuen Formen des Organizing widmete, ist die Dienstleistungsgewerkschaft Service Employees International Union (SEIU). Mit unkonventionellen Methoden gelang es der SEIU, beachtliche Organisierungserfolge bei Beschäftigtengruppen zu erzielen, die innerhalb der US-amerikanischen Gewerkschaftsbewegung lange als unorganisierbar galten. Exemplarisch stehen dafür die Erfahrungen der Kampagne Justice for Janitors (Milkman, 2006; Choi, 2008), die für die Organisierung der überwiegend prekär beschäftigten und migrantisch geprägten Belegschaften im Reinigungsgewerbe stritt. Hier nutzte die Gewerkschaft neben Community-Organizing-Elementen, bei denen migrantische Netzwerke in den Organisierungsprozess einbezogen werden, vor allem konfrontative Taktiken, mit dem Ziel, die vergleichsweise geringe Produktionsmacht der Beschäftigten mit Demonstrationen und Öffentlichkeitsarbeit zu kompensieren. So wurden etwa in Aufsehen erregenden Aktionen die Auftraggeber von Reinigungsfirmen mit den schlechten Arbeitsbedingungen der Reinigungskräfte konfrontiert, um so über die Kundschaft indirekten Druck auf die Reinigungsfirmen auszuüben. Des Weiteren verfolgten die Organizing-Kampagnen das Ziel, die Beschäftigten selbst zu Akteuren der Organisierung zu machen.

Der Organizing-Begriff ist schillernd und auch in der Literatur nicht immer eindeutig bestimmt. Carola Frege (2000, S. 142-144) entwickelt einen Organizing-Begriff entlang dreier Bedeutungsebenen. Auf der methodischen Ebene charakterisieren den OrganizingAnsatz demnach zunächst innovative Werbepraktiken, die auf einer systematischen und planvollen Durchführung von Organizing-Kampagnen beruhen. Zudem propagiere der Organizing-Ansatz auf einer inhaltlichen Ebene die Wiederbelebung von Gewerkschaften als 
umfassende soziale Bewegung der arbeitenden Bevölkerung, die nicht nur die unmittelbaren Probleme am Arbeitsplatz, sondern das ganze Lebensumfeld zum Gegenstand haben müsse. Um durchsetzungsfähig zu werden, bedürfe eine derartige Bewegung zudem der Mitgliedermobilisierung in kollektiven Aktionen, die im Gegensatz zu einer politischen Kultur der Kooperation deutlich konfliktorientiert agiert. Auf einer strukturellen Ebene identifiziert Frege schließlich die Ausrichtung auf die aktive Integration der Mitglieder in die Gewerkschaftsorganisation, die auf einer demokratischen und partizipativen Mobilisierungskultur basiert. Die Mitglieder sollen zur Beteiligung ermutigt und damit die Funktionärsgewerkschaft durch die Beteiligungsgewerkschaft abgelöst werden. Der Bewegungscharakter des Organizing-Ansatzes zeigt sich in dieser Begriffsbestimmung sowohl auf inhaltlicher als auch auf struktureller Ebene. Im Sinne eines Social Movement Unionism (Brinkmann et al., 2008, S. 84-94) gelte es, die Gewerkschaften wieder zu einer umfassenden sozialen Bewegung der arbeitenden Klassen zu machen und dabei über die betrieblichgewerkschaftlichen Kämpfe hinaus gesellschaftspolitische Forderungen zu formulieren und zu diesem Zweck die Mitglieder zu kollektiven Aktionen zu mobilisieren. Diese Aktionsorientierung wird getragen von einer partizipativen Mobilisierungskultur, die die Gewerkschaftsmitglieder zur aktiven Beteiligung an der Entwicklung gewerkschaftlicher Forderungen und der konkreten Ausgestaltung einer Kampagne motiviert. Der hier umrissene Bewegungscharakter des Organizing-Ansatzes wird auch in der entsprechenden Forschungsliteratur reflektiert, die sich unter dem Label Labor Revitalization Studies (LRS) (Kelly \& Frege, 2004; Hyman, 2007) etabliert hat.

Mit besonderer Aufmerksamkeit hat sich ein Teil dieser Forschungsarbeiten der Frage nach der gewerkschaftlichen Führung zugewandt und deren Bedeutung für den organisatorischen Erneuerungsprozess herausgestellt (Voss \& Sherman, 2000). Zugleich betonen die Arbeiten, die sich der Revitalisierungsforschung zuordnen lassen, dass erfolgreiche Erneuerungsprozesse als ein Ineinandergreifen von guter Führung, Mobilisierung und Selbstermächtigung (Empowerment) der Gewerkschaftsbasis zu verstehen sei (vgl. Hurd, Milkman \& Turner, 2003; Voss \& Sherman, 2000, S. 313; Hyman, 2007, S. 198-199). Im Rahmen dieses Forschungsprogrammes der LRS sind in den vergangenen Jahren eine Vielzahl von Studien durchgeführt worden, die sich Organisierungskampagnen von Gewerkschaften widmen und dabei insbesondere das Zusammenspiel von hauptamtlichen Gewerkschaftern und ehrenamtlichen Gewerkschaftsaktivisten in den Blick nehmen. Zentral ist dabei die Frage nach dem strategischen Handlungsvermögen, das Gewerkschaften im Organisierungsprozess entwickeln müssen, um tatsächlich erfolgreich arbeiten zu können. Hierbei greifen die Autorinnen und Autoren auf Ansätze der Forschung zu Sozialen Bewegungen zurück, die auf die Ressourcenausstattung, die Nutzung politischer Gelegenheitsstrukturen und damit verbundener framingProzesse abzielen (McAdam, Tarrow \& Tilly, 2003; Gahan \& Pekarek, 2013; Davis, McAdam, Scott \& Zald, 2005). In Ergänzung dieser Ansätze betont Marshall Ganz (2000, S. 1009), dass die bloße Bestimmung der Ressourcenausstattung oder sich bietender Gelegenheitsstrukturen nicht ausreicht, um den Erfolg oder Misserfolg gewerkschaftlicher Organisierungskampagnen erklären zu können. Vielmehr komme es auf das strategische Handlungsvermögen der handelnden Akteure an, die über entsprechende Fähigkeiten verfügen müssen, um die vorhandenen Ressourcen tatsächlich nutzen zu können und Gelegenheitsstrukturen als solche zu erkennen. Ganz benennt mit Führung und Organisation zwei Ebenen, auf denen 
sich das strategische Handlungsvermögen von Gewerkschaften analysieren lässt. Auf der Ebene Führung problematisiert Ganz die hauptamtlichen Führungskräfte der Gewerkschaft in einer Organisierungskampagne. Hier sind neben dem biographischen Hintergrund und der Einbindung in soziokulturelle Netzwerke insbesondere die Erfahrungen und das Aktionsrepertoire von Führungskräften von Bedeutung. Auf der Ebene Organisation werden darüber hinaus die deliberative Ausrichtung der Kampagne, der Ressourcenfluss und die Verantwortlichkeitsstrukturen thematisiert (Ganz, 2000, S. 1019). Für den hier zu diskutierenden Zusammenhang ist insbesondere die deliberative Ausrichtung einer Kampagne von Bedeutung und damit die Interaktion zwischen gewerkschaftlicher Basis und Führung, die auch Hyman (2007) hervorhebt und als besondere Herausforderung der Gewerkschaftsbewegung beschreibt. Es bedürfe sowohl der Selbstaktivität der gewerkschaftlichen Basis und entsprechender Möglichkeiten der Partizipation als auch einer übergeordneten Führung, die die Schwächen rein dezentral ausgerichteter Gewerkschaftsstrukturen durch Koordination und Abstimmung ausgleichen müsse. Zur genaueren Bestimmung der Partizipation der Gewerkschaftsbasis lassen sich in Anschluss an Linda Jill Markowitz (2000) Basisbestimmungen für eine beteiligungsorientierte Gewerkschaftsarbeit entwickeln. In Auseinandersetzung mit demokratietheoretischen Debatten benennt die Autorin drei Elemente partizipatorischer Demokratie. Diese bedürfe erstens der Bereitstellung aller relevanten Informationen, auf deren Basis dann Entscheidungen getroffen werden können (Markowitz, 2000, S. 41-42). Auf Grundlage dieser transparenten Informationen nennt Markowitz die offene Kommunikation als zweites Element partizipatorischer Kampagnen. Hiermit ist insbesondere gemeint, dass im Rahmen der Kampagne Orte geschaffen werden, an denen offen diskutiert, neue Themen eingebracht, das Vorgehen, die Mittel und auch die Ziele einer Kampagne zur Diskussion gestellt werden können. Damit wiederum verbunden ist das dritte Element, das eine gemeinsame Entscheidungsfindung als Basis für partizipatorische Demokratie benennt, womit betont wird, dass alle Beteiligten tatsächlich eine Entscheidung über die aufgeworfenen Themen treffen können (Markowitz, 2000, S. 43).

Der Organizing-Ansatz erhält seinen Bewegungscharakter ganz wesentlich über seine Orientierung auf die gewerkschaftliche Basis. Letztere gilt es im Rahmen der gewerkschaftlichen Organisierung zu Beteiligung und Selbsttätigkeit zu motivieren, um darauf aufbauend Organisationsmacht zu entwickeln, die dann in Mobilisierungs- und Konfliktfähigkeit umgesetzt werden kann. Mit Organizing stellt sich letztlich die Frage, inwiefern die systematische Beteiligung der gewerkschaftlichen Basis zu einer Revitalisierung der Gewerkschaften beitragen kann. Vor dem Hintergrund der Nutzung von Organizing-Ansätzen im deutschen Institutionensystem der industriellen Beziehungen lassen sich darüber hinaus Fragen der innergewerkschaftlichen Demokratie und der Kompatibilität mit den Institutionen der betrieblichen Interessenvertretung thematisieren.

\subsection{Das duale System der Interessenvertretung}

Zur Bestimmung des deutschen Modells der industriellen Beziehungen liefern die Arbeiten von Walther Müller-Jentsch hilfreiche Hinweise für eine systematische Einordnung. Für Deutschland beschreibt Müller-Jentsch (2017) die Austauschbeziehungen zwischen Kapital und Arbeit mit der von ihm geprägten Wortschöpfung der Konfliktpartnerschaft. Die Konfliktpartnerschaft basiert demnach auf einem „Interessenarrangement zwischen Kapital, Ar- 
beit und Staat“ (Müller-Jentsch, 2017, S. 20), durch das sich ein Organisations- und Institutionensystem der industriellen Beziehungen etablieren konnte, das „Orte geregelter Konfliktaustragung“ (Müller-Jentsch, 2017, S. 6) hervorbringt. Diese „Orte“ fasst MüllerJentsch als Arenen, die entlang unterschiedlicher rechtlicher Grundlagen festlegen, welche Konfliktgegenstände in der jeweiligen Arena bearbeitet werden können. Darüber hinaus werden entlang der verschiedenen Arenen die Akteure und auch die Konflikt- und Austragungsformen bestimmt. Für das deutsche System der industriellen Beziehungen ergibt sich eine Dualität, die einerseits die betriebliche Arena und andererseits die Arena der Tarifautonomie umfasst. In der betrieblichen Arena gelten die rechtlichen Bestimmungen des Betriebsverfassungsgesetzes, das Betriebsräte und Geschäftsleitung als zentrale Akteure bestimmt. Die Arena der Tarifautonomie wird dagegen von Kollektivakteuren getragen: Arbeitgeberverbänden und Gewerkschaften. Müller-Jentsch geht in seiner Konzeption zwar von der Konfliktträchtigkeit der Beziehungen zwischen Kapital und Arbeit aus, betont aber zugleich, dass es zu Interessenarrangements kommen kann, die zu ,relativ dauerhaften Kompromissstrukturen“ (Müller-Jentsch, 2017, S. 20) führen. Die beteiligten Akteure sind demnach in der Lage, innovative institutionelle Lösungen zu finden, um die wiederkehrenden Konfliktkonstellationen geregelt bearbeiten zu können. Einen nationalspezifischen Entwicklungspfad dieser evolutionären Entwicklung stellt nach Müller-Jentsch das duale System der Interessenvertretung für Deutschland dar. Derart institutionalisierte Formen, die staatlicherseits von entsprechenden Rechtsnormen getragen werden, erzeugen demnach eine Pfadabhängigkeit, die zu einer Orientierung an bestehenden Institutionen verpflichten und darüber auch zur Stabilität dieses partnerschaftlichen Interessenarrangements beitragen (Müller-Jentsch, 2017, S. 20). Auch Rudi Schmidt und Rainer Trinczek (1991, S. 170) konstatieren einen kooperativen Charakter der deutschen Arbeitsbeziehungen, den sie als Ausdruck starker Verrechtlichung und Zentralisierung verstehen. Zudem halten sie fest, dass das duale System der Interessenvertretung durch einen repräsentativen Politikmodus charakterisiert sei, der die Einflussmöglichkeiten und Selbsttätigkeit der Beschäftigten deutlich limitiere. Weil sich der Einfluss der Beschäftigten auf die Politik des Betriebsrates auf die alle vier Jahre stattfindenden Betriebsratswahlen reduziere, sprechen Schmidt und Trinzcek (1999, S. 111) von einer ,weitgehenden Exklusion der Belegschaft als relevantem politischen Akteur". Gewerkschaftsmitglieder haben formal zwar weiterreichende Möglichkeiten, sich an der innergewerkschaftlichen Willensbildung zu beteiligen. Allerdings hat sich hier eine faktische Zentralisierung der Entscheidungsbefugnisse bei den Hauptvorständen durchgesetzt (Bergmann, 1979, S. 211; Müller-Jentsch, 1997, S. 142-149; Asshoff, 2014), so dass die einfachen Mitglieder nur wenige Möglichkeiten haben, den Willensbildungsprozess tatsächlich wirkungsvoll zu beeinflussen. Ergebnis ist eine stark von Hauptamtlichen und Funktionsträgern geprägte Organisationsstruktur, die eine Beteiligung von einfachen Gewerkschaftsmitgliedern eher behindert als befördert.

Damit ist zunächst zu konstatieren, dass diese auf Stellvertretung und Interessenrepräsentation orientierten Politikformen sowohl die betriebliche als auch die gewerkschaftliche Interessenvertretung in Deutschland charakterisieren. Die starke Verrechtlichung orientiert insbesondere die Betriebsparteien, aber auch Arbeitgeberverbände und Gewerkschaften an einem Leitbild von Arbeitsbeziehungen, das partnerschaftliche und kooperative Beziehungen stützt. Inwiefern dieses institutionelle Arrangement auch heute noch die von Müller- 
Jentsch nahegelegte Stabilität aufweist, ist allerdings in Frage zu stellen (Haipeter, 2011; Dörre, 2016; Streeck, 2016). Einiges spricht dafür, dass der institutionelle Rahmen und dessen rechtliche Grundlagen zwar erhalten bleiben, die Regelungsinhalte, über die diese Institutionen $\mathrm{zu}$ entscheiden haben, aber immer deutlichere Zeichen der Erosion aufweisen (Dörre \& Schmalz, 2013, S. 24). Zudem lässt sich mit Klaus Dörre (2010) die vermeintliche Stabilität des institutionellen Arrangements der deutschen Arbeitsbeziehungen auch anders problematisieren, indem die Perspektive der Gewerkschaften berücksichtigt wird. Wenn resümiert werden kann, dass die deutschen Gewerkschaften nach dem zweiten Weltkrieg vergleichsweise erfolgreich institutionelle Machtressourcen für sich zu nutzen verstanden, konstatiert Dörre, dass sich damit auch das strategische Handeln von Gewerkschaften entsprechend verschoben habe. Die Fokussierung auf institutionelle Machtressourcen habe dazu geführt, dass die Gewerkschaften ihre primären Machtressourcen (strukturelle und Organisationsmacht) zunehmend vernachlässigten und sich darüber der Gefahr aussetzten, auch institutionelle Machtressourcen einzubüßen (Brinkmann et al., 2008, S. 24-26; Dörre, 2010, S. 883). Vergleichbar mit Müller-Jentschs Postulat der Pfadabhängigkeit geht auch Dörre davon aus, dass derart institutionalisierte Formen der Arbeitsbeziehungen dazu beitragen, dass die entsprechenden Akteure ihr Handeln entlang der bewährten institutionellen Pfade ausrichten. Im Unterschied zu Müller-Jentsch weist Dörre allerdings darauf hin, dass aus gewerkschaftlicher Perspektive darin auch eine Gefahr liegt:

\footnotetext{
„So legen institutionalisierte Arbeitsbeziehungen Verbänden wie Gewerkschaften Handlungsstrategien nahe, die auch dann noch überzeugend erscheinen, wenn sich gesellschaftliche Kräfteverhältnisse bereits gravierend verändert haben. Die Chance institutionelle Macht über ihre Erzeugungsbedingungen hinaus wirksam werden zu lassen, kann kollektive Akteure aber auch dazu animieren, Repräsentationsdefizite mittels institutionenkonformen Verhaltens kompensieren zu wollen. In diesem Fall laufen vor allem die LohnabhängigenOrganisationen beständig Gefahr, Handlungsstrategien zu konservieren, denen die Geschäftsgrundlage längst abhandengekommen ist.“ (Dörre, 2010, S. 891)
}

Dörre argumentiert in der Folge, dass die etablierten institutionellen Rahmenbedingungen dauerhaft nur erhalten bleiben können, wenn es den Gewerkschaften gelinge, mit struktureller und Organisationsmacht die wichtigsten Quellen von Lohnabhängigenmacht nachhaltig $\mathrm{zu}$ reproduzieren und damit letztlich auch den Bestand und die Funktionsweise institutioneller Machtressourcen abzusichern (Dörre, 2016, S. 351). Vor diesem Hintergrund erhalten betriebliche Organisierungsbemühungen von Gewerkschaften und insbesondere Organizing-Kampagnen entscheidende Bedeutung für die Frage nach tauglichen Strategien zur Stärkung der gewerkschaftlichen Organisationsmacht und darüber hinaus für die weitere Entwicklung des Systems industrieller Beziehungen.

\subsection{Organizing-Debatte in Deutschland}

In Deutschland wird die Debatte um Organizing von der Frage nach der Übertragbarkeit bestimmt. Schnell wurde von Seiten der Wissenschaft und aus den Gewerkschaften auf die grundlegenden Unterschiede der Ausgangsbedingungen für gewerkschaftliche Arbeit in den USA und Deutschland hingewiesen. Während sich US-Gewerkschaften einzig über die massive Organisierung von Beschäftigten in eine Verhandlungsposition mit einem Unternehmen bringen können, verfügen deutsche Gewerkschaften im Rahmen des dualen Systems der Interessenvertretung über ,staatliche Organisationshilfen“ (Rehder, 2008, S. 438), 
die sie in gewissen Grenzen unabhängig von der unmittelbaren Organisierung der Beschäftigten macht. Mit einiger Berechtigung argumentieren die Autorinnen und Autoren, die dem Organizing-Ansatz kritisch gegenüberstehen, dass die Mitgliederfrage vor dem Hintergrund des jeweiligen nationalen Systems ganz unterschiedliche Relevanz besitzt und daher auch in Zweifel gezogen werden kann, inwiefern die konfrontativen, auf Mobilisierung und Beteiligung ausgelegten Organizing-Praktiken der US-Gewerkschaften auf die deutschen Verhältnisse übertragen werden können. Britta Rehder (2008, S. 436-438) gibt etwa zu bedenken, dass mit der Orientierung auf die Beteiligung der Gewerkschaftsmitglieder eine zentrale strukturelle Grundlage des deutschen Modells der klassenbasierten Einheitsgewerkschaften in Bewegung kommt, da auf diesem Weg die auf institutionelle Einbindung der Gewerkschaften beruhende Einflusslogik zugunsten der Mitgliedschaftslogik geschwächt werde. Neben der Störung etablierter sozialpartnerschaftlicher Arrangements könnte das auch die Aufgabe der Kollektivrechts-Orientierung der deutschen Arbeitsbeziehungen nach sich ziehen (Rehder, 2014, S. 256-258). Des Weiteren konstatieren die kritischen Stimmen, dass die Fokussierung US-amerikanischer Organizing-Kampagnen auf betriebliche Themen in Deutschland mit den rechtlichen Trennungslinien des dualen Systems kollidiere. Da hier die Betriebsverfassung bestimmte Regulierungsgegenstände auf der betrieblichen Ebene an die Betriebsräte delegiere, seien diese Themen weitgehend vom Einflussbereich der Gewerkschaften getrennt, so dass eine entsprechende gewerkschaftliche Intervention erschwert werde (Frege, 2000, S. 276). Jürgen Prott (2013, S. 239) fürchtet in diesem Zusammenhang „unabsehbare Folgen“ für die Beziehungen zwischen Betriebsräten und Gewerkschaften, wenn letztere im Rahmen von betrieblichen Organisierungskampagnen bewährte Arrangements zwischen Betriebsräten und Gewerkschaften in Fragen der Mitgliederwerbung zur Disposition stellten. ${ }^{1}$ Überhaupt erkennt Prott im Aufbau von Organizing-Aktivenkreisen die Gefahr, dass diese an gewachsenen betrieblichen Strukturen vorbei agieren und darüber etwa bestehende Vertrauensleutestrukturen als ehrenamtliche Repräsentation der Gewerkschaftsmitglieder im Betrieb beschädigen könnten (Prott, 2013, S. 246-247). Im Zusammenhang mit dem Beteiligungsanspruch des Organizing sieht Prott zudem repräsentative Politikformen und demokratische Prinzipien der Gewerkschaften bedroht, da Organizing auf dem folgenden Partizipationskonzept basiere:

„Im Rahmen eines kampagnenförmigen Politikmodus lebt Beteiligung von der unmittelbaren Aktion. Sie
wird eher spontan als geplant, fast immer direkt statt indirekt und grundsätzlich kurzfristig statt langfristig
vorwiegend kleinräumig in Szene gesetzt. Mobilisierte Beteiligung dieses Typs hat damit eine ganz andere
sinnliche Dimension als die langfristig geplante, in repräsentative Muster eingefügte Regelhaftigkeit des in
Gewerkschaftssatzungen verankerten demokratischen Prinzips.“(Prott, 2013, S. 247)

Die von Prott hier vorgenommene Charakterisierung des Organizing-Konzeptes soll im Folgenden als Ausgangspunkt für die Bestimmung eines Spannungsverhältnisses dienen, das sich aus einer Nutzung des Organizing-Ansatzes unter den Bedingungen des dualen Systems der Interessenvertretung ergibt. Während das duale System verrechtlichte Stellvertretungsverhandlungssysteme etabliert, die auf der weitgehenden Passivität der Beschäftig-

1 Trotz der formalen Trennung zwischen den Aufgabenbereichen haben sich zwischen Betriebsräten und Gewerkschaften sowohl auf personaler als auch funktionaler Ebene enge wechselseitige Bezüge herausgebildet (Schmidt \& Trinczek, 1991, S. 179-178). So dienen gewerkschaftlich organisierte Betriebsräte insbesondere als Basis für die gewerkschaftliche Mitgliederwerbung im Betrieb (Behrens, 2005). 
ten/Mitglieder beruhen, setzt der Organizing-Ansatz auf die Aktivierung und Selbsttätigkeit der Beschäftigten/Mitglieder. Damit gehen ganz unterschiedliche Anforderungen an die beteiligten Akteure einher, die bei einem Zusammentreffen beider Konzepte ein Spannungsverhältnis begründen. Im Folgenden soll dieses Spannungsverhältnis zwischen dualem System und Organizing-Ansatz entlang der drei Dimensionen Interessenartikulation (1), Konfliktbearbeitung (2) und Organisation (3) näher bestimmt werden.

Mit der Dimension der Interessenartikulation tritt der repräsentative Charakter des dualen Systems zutage. Betriebsräte und Gewerkschaften müssen Interessen der Beschäftigten/ Mitglieder entlang der gesetzlichen Grundlagen bzw. der gewerkschaftlichen Beschlusslage stellvertretend definieren. Der Betriebsrat fungiert dabei als Repräsentativorgan, auf das die Belegschaft nur alle vier Jahre über die Betriebsratswahl Einfluss nehmen kann. Abgesehen vom Wahlakt sind die Beschäftigten damit auf eine weitgehend passive Rolle verwiesen (MüllerJentsch, 2017, S. 49). ${ }^{2}$ Die Organisationsstrukturen deutscher Gewerkschaften sind wiederum durch einen starken Zentralismus gekennzeichnet, der sich u.a. in einer Kompetenzanhäufung bei zentralen Führungsorganen ausdrückt und die Mitwirkung der Mitglieder bezüglich der Richtungsbestimmung der Politik deutlich limitiert (Müller-Jentsch, 1997, S. 146-147). Auf Seiten des Organizing-Ansatzes steht dagegen die systematische Aufforderung an die Beschäftigten, sich aktiv an der Interessengestaltung zu beteiligen, eigene Themen einzubringen und damit aktiv die betriebliche Interessenpolitik mitzugestalten. Damit stehen Betriebsräte und das hauptamtliche Personal der Gewerkschaften vor der Herausforderung, die tradierte Praxis der Stellvertretung zu reflektieren und systematisch um Elemente zu erweitern, die eine Beteiligung der Beschäftigten an der betrieblichen Interessenpolitik ermöglichen und befördern. Eine derartige Ausrichtung erfordert neben der Bereitschaft, die privilegierte Repräsentationsrolle zumindest partiell aufzugeben, auch die Verfügung über entsprechende zeitliche Ressourcen und spezifische Fähigkeiten der Akteure, die ihnen die Durchführung von Beteiligungsprozessen überhaupt ermöglicht. Spannungen sind zu erwarten, wenn die relevanten Akteure der Interessenvertretung nicht willig oder fähig sind, die entsprechenden Beteiligungselemente in ihre Interessenvertretungspraxis zu integrieren.

Das Spannungsverhältnis zwischen Organizing-Ansatz und dualem System der Interessenvertretung lässt sich auch entlang der zweiten Dimension Konfliktbearbeitung identifizieren. Das duale System delegiert bestimmte Regulierungsgegenstände an verschiedene Akteure und definiert damit zugleich, welche Konflikt- und Austragungsformen zu deren Bearbeitung genutzt werden dürfen. Während die Gewerkschaften für den Abschluss eines Tarifvertrages unter der Einhaltung der entsprechenden rechtlichen Bestimmungen auch zu Streiks aufrufen dürfen, bleiben dem Betriebsrat derartige Kampfmittel untersagt. Er ist laut Betriebsverfassung zur vertrauensvollen Zusammenarbeit mit der Geschäftsleitung verpflichtet und damit auf betriebliche Verhandlungskorridore der Konsultation zwischen Geschäftsleitung und Betriebsrat orientiert. Betriebliche Organizing-Prozesse liegen quer zu diesen Bestimmungen des dualen Systems, weil sie entgegen dieser Aufgabenteilung zwischen Betriebsrat und Gewerkschaft zum einen explizit betriebliche Themen aufgreifen, obwohl diese klar im Aufgabenbereich des Betriebsrates angesiedelt sind und zum anderen

2 Partizipationsrechte, die den Beschäftigten mit der Novellierung des BetrVG 2001 eingeräumt werden, stellen eine partizipative Erweiterung der Betriebsverfassung dar, verändern aber nicht deren grundsätzlich repräsentativen Charakter. 
ganz andere Formen der Konfliktbearbeitung anvisieren. So werden Forderungen und Interessen der Belegschaft nicht (ausschließlich) über Stellvertretungsverhandlungssysteme bearbeitet, sondern vor allem über die direkte Mobilisierung der Beschäftigten, womit es zur direkten Konfrontation von Belegschaft und der Kapitalseite kommt.

Zuletzt zeigt auch die Dimension Organisation deutliche Unterschiede an: Während das duale System Institutionen/Akteure der Interessenvertretung einsetzt, die nach formalen Regeln durch Wahlen aus der Belegschaft bestimmt werden, finden sich im Rahmen von Organizing-Prozessen die Träger eines Organisierungsprozesses in den weitgehend nicht-formalisierten Aktivenkreisen zusammen. Während das duale System also auf regelhaft-geplante und Langfristigkeit ausgelegte Formen der Interessenvertretung basiert, wirken im Rahmen von Organizing-Prozessen spontane Zusammenschlüsse von Beschäftigten, die jenseits formaler Regeln und nur kurzfristig zu Akteuren betriebspolitischer Interventionen werden.

Obwohl die Debatte um Organizing in Deutschland bereits seit Jahren geführt wird, beruht sie im Wesentlichen im Rekurs auf die unterschiedlichen institutionellen Hintergründe, von denen - wie hier überblickartig vorgestellt - angenommen wird, dass sie zu Übertragungsschwierigkeiten und Unvereinbarkeiten führen. Es fällt allerdings auf, dass die Debatte häufig ohne Bezüge auf konkrete Erfahrungen mit Organizing-Projekten in Deutschland auskommt und daher auf eine empirische Leerstelle verwiesen ist. Zu Organizing-Projekten deutscher Gewerkschaften gibt es nur eine Handvoll öffentlich zugänglicher Studien. Während insbesondere die frühen Untersuchungen häufig Konflikte zwischen Betriebsräten und Organizing-Aktivenkreise problematisierten (Bremme, 2007, S. 215; Birke, 2010, S. 148-149), geben neuere Studien vermehrt Hinweise, dass Organizing-Prozesse auch in gelungener Kooperation mit Betriebs- bzw. Personalräten durchgeführt werden können. Oliver Nachtwey und Marcel Thiel sprechen im Zusammenhang mit einer Untersuchung eines OrganizingProjektes im Krankenhauswesen von ,pfadabhängiger Revitalisierung“ (Nachtwey \& Thiel, 2014, S. 274) und betonen, dass durch Organizing-Prozesse nicht nur die gewerkschaftliche Organisationsmacht im Betrieb gestärkt, sondern auch institutionelle Machtressourcen erweitert werden, weil sich die gewerkschaftliche Verankerung im Personalrat verbesserte.

\section{Organizing in der Windbranche: Ergebnisse aus betrieblichen Fallstudien}

Einige Aufschlüsse über die Organizing-Praxis deutscher Gewerkschaften können von der Auswertung der Untersuchungsergebnisse eines überregional koordinierten OrganizingProjekts der IG Metall erwartet werden, das zwischen 2011 und 2013 in der Windindustrie durchgeführt wurde (Dribbusch, 2013; Thünken, 2013). Dazu wurden im Rahmen eines Dissertationsprojektes 35 Experteninterviews mit Betriebsräten, gewerkschaftlichen Aktiven und dem hauptamtlichen Gewerkschaftspersonal (Organizer) geführt und im Rahmen einer qualitativen Inhaltsanalyse ausgewertet. ${ }^{3}$ Auf dieser Basis sind Fallstudien erarbeitet worden, die auf Untersuchungen in vier Produktionsbetrieben, einem Standort mit Service-

3 Die Interviews wurden zum Ende der Laufzeit des Organizing-Projekts geführt und können daher nur eingeschränkt Auskunft über die Nachhaltigkeit der untersuchten Organisierungsprozesse geben. 
und Verwaltungsaufgaben und einem Forschungs- und Entwicklungsstandort basieren (s. Tabelle 1). Die Betriebe waren zu Projektbeginn weitgehend gewerkschaftlich unerschlossen, d.h. es gab nur eine marginale Anzahl oder überhaupt keine Gewerkschaftsmitglieder unter den Beschäftigten, und auch die Betriebsräte waren überwiegend nicht gewerkschaftlich organisiert oder verfügten über keine enge Bindung an die Gewerkschaft. Bis auf den Fallbetrieb Turmbau verfügten alle Betriebe zu Beginn des Organizing-Projekts über einen Betriebsrat. Während das eigentümergeführte Unternehmen Turmbau massiv Druck auf die Beschäftigten ausübte, um eine Betriebsratsgründung zu verhindern, bestanden die Betriebsratsgremien in den anderen Fallbetrieben bereits über mehrere Jahre und hatten nicht mit vergleichbaren Formen des Arbeitgeberwiderstands zu kämpfen. Gleichwohl können nur drei der fünf Betriebsratsgremien des Samples als vertretungswirksame Interessenvertretung (Kotthoff, 1994, S. 64) eingeordnet werden. Für diese drei Fallbetriebe gelten Interaktionsbeziehungen zwischen Betriebsrat und Management, die sich dem Typ der Integrationsorientierten Kooperation zuordnen lassen (Bosch, Ellguth \& Trinczek, 1999, S. 9192). Für diesen Interaktionstyp ist charakteristisch, dass die Betriebsparteien bei wechselseitiger Anerkennung der unterschiedlichen Interessen, auf partnerschaftliche Beziehungen orientiert sind und sich um einen Ausgleich in Verhandlungen bemühen. Die Fallbetriebe Generator und Rotorblatt kennzeichnet dagegen, dass sie zu Projektbeginn u.a. aufgrund personeller Umbrüche in den Gremien nur eingeschränkt arbeitsfähig waren und von Seiten der Unternehmensführung häufig ignoriert und bewusst übergangen wurden. In der Folge hatten die Betriebsräte in beiden Betrieben damit zu kämpfen, dass sie von Teilen der Belegschaft nicht mehr als Interessenvertretung anerkannt wurden. Die Betriebsräte der Fallbetriebe Generator und Rotorblatt werden hier aufgrund ihrer mangelnden Vertretungswirksamkeit als defiziente Form der Interessenvertretung gekennzeichnet (Kotthoff, 1994, S. 64). Tabelle 1 gibt einen entsprechenden Überblick über die Fallbetriebe.

Tabelle 1: Fallbetriebe

\begin{tabular}{|c|c|c|c|c|c|}
\hline Fallbetrieb & Betriebstyp & $\begin{array}{l}\text { Beschäftigten- } \\
\text { gruppen }\end{array}$ & $\begin{array}{l}\text { Beschäftigten- } \\
\text { zahl }\end{array}$ & $\begin{array}{l}\text { Betriebsrat-Typ } \\
\text { zu Projektbeginn }\end{array}$ & $\begin{array}{l}\text { Haltung des Be- } \\
\text { triebsrat zur Ge- } \\
\text { werkschaft }\end{array}$ \\
\hline Generator & Produktion & Fachkräfte & $\begin{array}{l}200 \\
50 \% \text { Leiharbeit } \\
\end{array}$ & $\begin{array}{l}\text { Defiziente Interessen- } \\
\text { vertretung }\end{array}$ & Zusammenarbeit \\
\hline Rotorblatt & Produktion & $\begin{array}{l}\text { Fachkräfte und } \\
\text { Angelernte }\end{array}$ & $\begin{array}{l}730 \\
60 \% \text { Leiharbeit }\end{array}$ & $\begin{array}{l}\text { Defiziente Interessen- } \\
\text { vertretung }\end{array}$ & Zusammenarbeit \\
\hline $\begin{array}{l}\text { Forschung \& } \\
\text { Entwicklung }\end{array}$ & $\begin{array}{l}\text { Forschung \& } \\
\text { Entwicklung }\end{array}$ & $\begin{array}{l}\text { Ingenieurwesen und } \\
\text { Verwaltung }\end{array}$ & 700 & $\begin{array}{l}\text { Integrationsorientierte } \\
\text { Kooperation }\end{array}$ & Distanz \\
\hline Generator II & Produktion & Fachkräfte & 150 & $\begin{array}{l}\text { Integrationsorientierte } \\
\text { Kooperation }\end{array}$ & Zusammenarbeit \\
\hline $\begin{array}{l}\text { Service und } \\
\text { Verwaltung }\end{array}$ & $\begin{array}{l}\text { Service, Mon- } \\
\text { tage \& Ver- } \\
\text { waltung }\end{array}$ & $\begin{array}{l}\text { Montagefachkräfte } \\
\text { und Verwaltung }\end{array}$ & $\begin{array}{l}800 \\
(200 \text { Verwal- } \\
\text { tung, } 600 \text { Mon- } \\
\text { tage) }\end{array}$ & $\begin{array}{l}\text { Integrationsorientierte } \\
\text { Kooperation }\end{array}$ & Ablehnung \\
\hline Turmbau & Produktion & $\begin{array}{l}\text { Fachkräfte und } \\
\text { Angelernte }\end{array}$ & $\begin{array}{l}150 \\
50 \% \text { Leiharbeit }\end{array}$ & Kein Betriebsrat & Kein Betriebsrat \\
\hline
\end{tabular}

Quelle: Eigene Darstellung. 
Im Folgenden wird entlang der Fallstudienberichte der Bewegungscharakter von Organizing-Prozessen herausgearbeitet, der sich zentral in der Orientierung auf die Beteiligung, Mobilisierung und Aktivierung der Belegschaften darstellt (3.1 und 3.2). Unter Punkt 3.3 wird schließlich auf die Rolle der Betriebsräte in diesen Prozessen fokussiert und gezeigt, dass diese sowohl zu Protagonisten einer beteiligungsorientierten Erweiterung der betrieblichen Interessenvertretung werden können, als auch die Möglichkeit besteht, dass sich Betriebsräte einer solchen Orientierung verweigern und damit den Organizing-Prozess ausbremsen.

\subsection{Bewegungscharakter des Organizing und beteiligungsorientierte Erweiterung der betrieblichen Interessenvertretung}

Die Fallstudien dokumentieren, dass es im Rahmen von Organizing-Prozessen zu einer bemerkenswerten beteiligungsorientierten Erweiterung der betrieblichen Interessenvertretung gekommen ist. Die maßgeblichen Träger und Treiber dieser Beteiligung von Beschäftigten an der Interessenvertretungspraxis waren die im Rahmen von Organizing-Prozessen aufgebauten Aktivenkreise. In den Aktivenkreisen trafen sich die gewerkschaftlich interessierten Teile der Belegschaft und planten die Organisierung eines Betriebes. Diese Kreise waren zunächst offene Sammelpunkte, an denen Beschäftigte in den Austausch untereinander und mit den hauptamtlichen Organizern treten konnten. Im Verlauf von Organizing-Prozessen wurden die Aktivenkreise immer mehr zu Trägern eines betrieblichen Organisierungsprozesses, der zentral über die Beteiligung und Mobilisierung der Belegschaften geprägt wurde. Gerade diese Beteiligungsorientierung, die auf die Einbeziehung möglichst großer Teile der Belegschaft eines Betriebes ausgerichtet war, zeigt den Bewegungscharakter von betrieblichen Organizing-Prozessen an. Die Beschäftigten selbst sorgten, zunächst noch unter Anleitung hauptamtlicher Organizer, später mehr und mehr auf sich alleine gestellt, für die Planung und Durchführung einer Kampagne. Im Rahmen der Aktivenkreise trafen sich Beschäftigte um mögliche Themen der Kampagne zu diskutieren, Forderungen zu entwickeln und Aktionen zu planen. Die Aktiventreffen waren dabei weitgehend nicht-formalisiert, d.h. die Teilnahme war z.B. nicht an eine Gewerkschaftsmitgliedschaft oder der Übernahme einer Funktionsträgerschaft gebunden. Die Mitglieder von Aktivenkreisen waren auch keine Träger von Wahlmandaten, sondern stellten einen mehr oder weniger spontanen $\mathrm{Zu}$ sammenschluss von Beschäftigten dar.

Darüber hinaus zeigte sich der Bewegungscharakter des Organizing in der spezifischen Form der Konfliktbearbeitung. Neben der Tatsache, dass im Rahmen von Organizing-Prozessen die Konfrontation mit der Unternehmensleitung gesucht wird, war zentral, dass Forderungen nicht (nur) über formalisierte Verhandlungswege in Form repräsentativer Institutionen wie dem Betriebsrat gestellt wurden. Stattdessen war die Organizing-Konfliktbearbeitung vor allem durch die direkte Mobilisierung der Beschäftigten zu Kundgebungen, Veranstaltungen oder symbolischen Aktionen bei Betriebsversammlungen geprägt, bei denen die Unternehmensleitung direkt mit den Forderungen der Beschäftigten konfrontiert wurde und die Belegschaften damit einen aktiven Part im Verhandlungsprozess übernahmen. Neben die repräsentativ-formalisierten Verhandlungswege, wie sie etwa über entsprechende Rechte des Betriebsrates im BetrVG angelegt sind, trat damit eine Bewegungs- und Konfliktdynamik, die über die Einbeziehung der Beschäftigten einen direktdemokratischen 
und nicht-formalisierten Charakter annahm, der auch zentrale Konstitutionsbedingungen sozialer Bewegungen ausmacht. Dabei zeigen die Fallstudien, dass Aktivenkreise zur Bearbeitung ganz unterschiedlicher betrieblicher Themen genutzt wurden. Während sich die Aktiven des Fallbetriebs Turmbau zunächst der Wahl eines Betriebsrates widmeten, griffen die Aktiven des Produktionsstandortes Generator die Absetzung des Mittagessens, das bis dahin vom Unternehmen zur Verfügung gestellt wurde, auf und organisierten Protest. An zwei Produktionsstandorten (Turmbau und Rotorblatt) wurde unabhängig voneinander die Frage nach einer Änderung des Schichtsystems thematisiert und in Orientierung auf die Verabschiedung einer entsprechenden Betriebsvereinbarung bearbeitet. Am Standort Forschung \& Entwicklung sorgte schließlich ein intransparentes Entgeltsystem für Unmut unter den Beschäftigten, so dass die Aktiven dieses Thema ihrerseits aufgriffen. Des Weiteren spielten Aktivenkreise bzw. die aus diesen hervorgegangenen Vertrauensleute auch im Aushandlungsprozess um einen Tarifvertrag eine zentrale Rolle.

\subsection{Soziale Bewegung im Betrieb: Beteiligung, Mobilisierung und Aktivierung der Belegschaften}

Während die Gegenstände, denen sich die Organizing-Aktivenkreise widmeten, also durchaus verschieden waren, bestand das Charakteristische in der Form der Konfliktbearbeitung dieser Fragen. Nachdem die Aktivenkreise die Bearbeitung eines Themas in Betracht gezogen hatten, wurden zunächst Befragungen innerhalb der Belegschaft durchgeführt. Dies geschah in der Regel über schriftliche Fragebögen, die von den Aktiven an die Beschäftigten verteilt wurden. Dabei galt es, einfache Stimmungslagen, etwa das Interesse an der Beibehaltung des Mittagessens beim Fallbetrieb Generator oder die Zufriedenheit mit dem Schichtsystem beim Fallbetrieb Rotorblatt, zu erfragen. Wenn es entsprechende Rückmeldungen aus der Belegschaft gab, wurde die weitere Bearbeitung eines Themas durch den Aktivenkreis geplant und die Befragungsergebnisse unmittelbar betriebspolitisch genutzt. So organisierten die Aktiven bei Generator nach der Auswertung der Befragung eine Kundgebung zur Wiedereinführung des Mittagessens und mobilisierten die Belegschaft erfolgreich zu einer Aktion in der Mittagspause. Die Geschäftsleitung wurde auf diesem Weg direkt mit der Forderung der Belegschaft konfrontiert und kündigte in der Folge sowohl die Wiedereinführung des Mittagessens als auch die Einbeziehung des Betriebsrates an, der von der Geschäftsleitung in dieser Frage bis dahin ignoriert worden war.

In den Fallbetrieben, die sich der Veränderung des Schichtsystems widmeten, wurden die Umfragen genutzt, um dem Betriebsrat bei anberaumten Verhandlungen mit der Geschäftsleitung den Rücken zu stärken. In den betreffenden Betrieben waren die Betriebsräte aufgrund der Neugründung unerfahren (Turmbau), bzw. vertretungsschwach (Rotorblatt), so dass diese von der Geschäftsleitung nicht als ernstzunehmende Verhandlungspartner betrachtet und daher Verhandlungen über Veränderungen des Schichtsystems frühzeitig abgeblockt wurden. Im Rahmen des Organizing-Prozesses konnten die Betriebsräte zum einen durch ein systematisches Coaching der hauptamtlichen Organizer und zum anderen über den betriebspolitischen Druck, der durch die Beteiligung der Belegschaften in Form von Befragungen sowie der einsetzenden Organisierungsdynamik erzeugt wurde, nachhaltig gestärkt werden. Zudem wurde die Beteiligung der Belegschaften auch im Verlauf der Verhandlungen aufrechterhalten, indem nach jeder Verhandlungsrunde Vertrauensleutetreffen 
stattfanden und über den Stand der Verhandlungen berichtet wurde. Derart informiert konnten die Vertrauensleute der weiteren Belegschaft berichten, deren Anregungen und Kritik aufnehmen und diese wieder in die Verhandlungskommission tragen. In der Folge blieb das Schichtsystem über die gesamten Verhandlungen hinweg ein betriebspolitisches Thema, das von den Belegschaften wiederkehrend diskutiert und über entsprechende Beteiligungsangebote und -aufforderungen aktiv mitgestaltet wurde.

Beim Standort Forschung \& Entwicklung wurde das Entgeltsystem zum bestimmenden betrieblichen Thema, nachdem die Geschäftsleitung eine Neueingruppierung vorgenommen hatte, die auf massive Kritik in der Belegschaft stieß. Da das Entgeltsystem aufgrund intransparenter Eingruppierungsregeln schon längere Zeit für Gesprächsstoff im Betrieb sorgte, hatten sich sowohl der Betriebsrat als auch der Aktivenkreis dieser Frage angenommen. Die gewerkschaftlich Aktiven im Betrieb organisierten mehrere Informationsabende zum Entgeltsystem, bei denen es zu einem intensiven Austausch unter den Beschäftigten kam. In diesem Rahmen konnte ein Selbstaufklärungsprozess der Beschäftigten angestoßen werden, der die undurchsichtigen Entgeltstrukturen des Betriebes offenlegte und darüber eine betriebspolitische Diskussion forcierte. Die gut besuchten Informationsabende öffneten für breite Teile der Belegschaft einen Raum, um sich an dieser betriebspolitischen Diskussion zu beteiligen. In der Folge kam es zwar nicht zur Mobilisierung in Form von Demonstrationen, wie es an den Produktionsstandorten der Fall war, es ist jedoch zu berücksichtigen, dass die betriebsöffentlich angekündigten Infoabende durchaus den Charakter von Kundgebungen mit offenem Mikrophon annahmen, so dass von diesen Veranstaltungen auch ein betriebspolitisches Signal ausging.

$\mathrm{Zu}$ breiter Aktivierung der Beschäftigten führten auch die Tarifverhandlungen, die in drei der sechs Fallbetriebe (Generator, Rotorblatt und Forschung \& Entwicklung) geführt wurden. So bemühten sich die Aktivenkreise schon vor Aufnahme der Verhandlungen um Aktivitäten, die die streikunerfahrenen Belegschaften auf mögliche Warnstreikaktionen vorbereiten sollten. Dazu wurde etwa am Standort Forschung \& Entwicklung zu einem Spaziergang in der Mittagspause aufgerufen, der sich durch gute Beteiligung zu einer gewerkschaftlichen Demonstration über das Betriebsgelände ausweitete. An den Produktionsstandorten wurden immer wieder die Betriebsversammlungen für symbolische Aktionen genutzt. Um die Forderung nach einem Tarifvertrag zu verbreiten, entrollte der Aktivenkreis während der Rede der Geschäftsleitung ein Banner von enormer Größe, das mit einem Slogan (,Tarifvertrag - leider geil!“) versehen war. Dieser Slogan war in der überbetrieblichen Tarifbewegung aus den Betrieben heraus entwickelt worden und große Teile der Belegschaft identifizierten sich damit. Darüber hinaus zeigten die gewerkschaftlichen Aktiven reges Interesse an den Tarifverhandlungen und wählten dazu große betriebliche Tarifkommissionen, die auch entsprechenden Anspruch an Beteiligung und Transparenz hatten. Für den Fallbetrieb Forschung \& Entwicklung lassen sich in diesem Zusammenhang auch die Grenzen der Beteiligung aufzeigen. Während der Verlauf des Organizing-Prozesses im Fallbetrieb durchaus den Basisbestimmungen beteiligungsorientierter Gewerkschaftsarbeit entsprach (vgl. Kapitel 2.1), kam es im Laufe der sich lang hinziehenden Tarifverhandlungen zu einem Konflikt zwischen der gewerkschaftlichen Verhandlungsführung und den Vertrauensleuten, die zwischenzeitlich aus dem Aktivenkreis hervorgegangen waren. Während die Vertrauensleute auf möglichst umfassende Streuung der Informationen zum Stand 
der Verhandlungen pochten, bestand die Verhandlungsführung auf eine zurückhaltende Weitergabe entsprechender Informationen an die Belegschaft und setzte damit den Transparenz- und Beteiligungsbedürfnissen der gewerkschaftlichen Aktiven und Vertrauensleuten eine klare Grenze.

\subsection{Betriebsräte als Treiber und Bremser der Beteiligung}

Die Fallstudien zeigen, dass die betriebliche Interessenvertretung in Form der Betriebsräte entscheidenden Einfluss auf die Beteiligungsdynamik der Organizing-Prozesse nahm. Wenn es gelang, die Betriebsräte für den Organizing-Prozess zu gewinnen, wurden diese zu zentralen Akteuren, die lernten, Beteiligungselemente systematisch in ihre Arbeit zu integrieren und damit auch die Interessenvertretungswirksamkeit des Gremiums zu verbessern. Wenn Betriebsräte die gewerkschaftliche Organisierung im Betrieb dagegen nicht unterstützten, ihr neutral oder sogar ablehnend gegenüberstanden, bestand die Gefahr, dass der Prozess frühzeitig ausgebremst wurde.

Zunächst aber dokumentieren die Fallstudien, dass Betriebsräte durchaus für eine beteiligungsorientierte Interessenvertretungspraxis zu begeistern waren. Besondere Offenheit in diese Richtung bestand in Betrieben, in denen zum Auftakt von Organizing-Prozessen keinerlei arbeits- bzw. durchsetzungsfähige Strukturen bestanden und ein Betriebsrat erst gewählt oder konstituiert und damit häufig auch personell neu zusammengesetzt werden musste. Unter diesen Umständen durchliefen bereits bestehende Betriebsräte oder gewerkschaftliche Aktive, die im Prozessverlauf zu Betriebsratskandidaten aufgebaut wurden, eine Organizing-Bewegungsdynamik, die systematisch auf die Beteiligung der Belegschaft setzte. Diese Fälle charakterisierte eine enge Zusammenarbeit und Abstimmung zwischen Aktivenkreis und Betriebsrat. Auf Seiten der Betriebsräte erforderte das, neben der Bereitschaft entsprechende zeitliche Ressourcen für die Teilnahme an Aktiventreffen, der Vorund Nachbereitung von Diskussionen aufzuwenden, auch eine Offenheit für Aktions- und Konfliktorientierung, die eine Organisierungsdynamik mit sich bringt. Die Fallstudien zeigen, wie isolierte Betriebsratsgremien darüber Handlungsfähigkeit erlangten und in die Lage versetzt wurden, interessenwirksame Interventionen zu führen. Die Beteiligung und Mobilisierung der Belegschaft wirkte dabei zunächst in Richtung einer Stärkung der Legitimation des Betriebsrates gegenüber der Geschäftsleitung, die durch die unmittelbare Mobilisierung der Belegschaft unter Druck gesetzt wurde. Das stärkte offenbar nachhaltig die Verhandlungsposition der Betriebsräte, die in der Folge eine andere Wahrnehmung durch die Geschäftsleitung erfuhren. Die Beteiligung der Belegschaften ermöglichte den Betriebsräten die unmittelbare Aufnahme von Stimmungen und Wahrnehmungen der Beschäftigten und unterstützte damit die Entwicklung des strategischen Handlungsvermögens der Interessenvertretung, das für die erfolgreiche Nutzung betriebspolitischer Gelegenheitsstrukturen von zentraler Bedeutung ist. Voraussetzung für die hier skizzierte beteiligungsorientierte Erweiterung der betrieblichen Interessenvertretung war allerdings, dass die entsprechenden Betriebsräte einer gewerkschaftlichen Organisierung offen und unterstützend gegenüber standen. In diesen Fällen kam es zu einer Verschmelzung von gewerkschaftlichen Aktiven und Betriebsrat, die eine entsprechende Entwicklungsrichtung begünstigte. Es zeigte sich allerdings, dass auch Betriebsräte, die einer gewerkschaftlichen Organisierung grundsätzlich positiv gegenüberstanden, nicht unbedingt den Beteiligungs- und Mobilisierungscha- 
rakter des Organizing-Ansatzes unterstützten. Im Fallbetrieb Generator II pflegte der Betriebsratsvorsitzende derart vertrauensvolle Beziehungen zur Geschäftsleitung, dass dieser trotz ausgewiesener gewerkschaftlicher Überzeugungen einen Konflikt mit der Geschäftsleitung um jeden Preis vermeiden wollte und damit einer typischen Organizing-Bewegungsdynamik den Weg versperrte. Es zeigt sich, dass Betriebsräte, die die traditionellen Verhandlungswege des dualen Systems als wirksam wahrnahmen, offenbar weniger Bereitschaft entwickelten, diese um eine konfliktorientierte Bewegungs- und Beteiligungsdynamik zu ergänzen.

Interessant sind auch diejenigen Fallbetriebe, in denen sich Betriebsratsgremien explizit gegen ein gewerkschaftliches Engagement im Betrieb aussprachen (Service und Verwaltung), bzw. einem solchen zumindest skeptisch gegenüberstanden (Forschung \& Entwicklung). Im ersten Fall führte das dazu, dass der Organizing-Prozess keinerlei betriebsöffentliche Dynamik entfalten konnte und die Organisierung der Belegschaft fast ausschließlich über persönliche Ansprache durchgeführt werden musste. Der personell kleine Aktivenkreis wagte es aufgrund der unnachgiebigen Haltung des Betriebsrates und der noch schwachen gewerkschaftlichen Basis im Betrieb nicht, eine eigenständige Position einzunehmen, die ihn womöglich nicht nur in Konfrontation mit der Geschäftsleitung sondern auch zum Betriebsrat gebracht hätte. Der Fallbetrieb Forschung \& Entwicklung dokumentiert dagegen, wie es den betrieblichen Aktiven und den Organizern gelang, erfolgreich neben dem mehrheitlich der Gewerkschaft skeptisch gegenüberstehenden Betriebsratsgremium Beteiligung und Unterstützung der Belegschaft in einer Bewegungsdynamik aufzubauen. Dies war einerseits möglich, weil es innerhalb des Betriebsrates eine anerkannte Minderheit gab, die den gewerkschaftlichen Organisierungsprozess offen unterstützte. Andererseits vermochte es der Aktivenkreis, eine Gelegenheitsstruktur zu nutzen, die sich mit der Überarbeitung des Entgeltsystems durch die Geschäftsleitung ergeben hatte. Die gewerkschaftlich Aktiven nahmen die Verärgerung der Belegschaft über fehlerhafte Neueingruppierungen auf und organisierten umgehend Informationsabende, die zu wichtigen Orten des Austausches unter den Beschäftigten wurden und entscheidend dazu beitrugen, dass sich der Aktivenkreis als betriebspolitischer Akteur neben dem Betriebsrat etablieren konnte. Hierbei waren die gewerkschaftlichen Aktiven zwar darauf bedacht, eigene Akzente zu setzten, bemühten sich aber zugleich, nicht in Konfrontation zum Betriebsrat zu geraten. Dies erforderte bei konkreten betrieblichen Fragen, wie der Kritik am betrieblichen Entgeltsystem, an dessen Ausarbeitung auch der Betriebsrat beteiligt war, das strategische Geschick der gewerkschaftlich Aktiven. Letztere forderten in diesem Zusammenhang den Abschluss eines Tarifvertrages, verbanden diese Forderung aber nicht mit einem expliziten Angriff auf den Betriebsrat, der sich mehrheitlich für die Lösung der Entgeltproblematik über eine Betriebsvereinbarung stark machte.

\section{Diskussion und Fazit}

Die Auszüge aus den betrieblichen Fallstudien haben gezeigt, dass gewerkschaftliche Organisierungsprozesse im Rahmen von Organizing-Projekten den Charakter sozialer Bewegungen annehmen und damit die Verfasstheit der industriellen Beziehungen in Deutschland 
herausfordern und zugleich Potenziale zur Revitalisierung dieses Institutionensystems entfalten können. Während das duale System der Interessenvertretung repräsentative, auf Ausgleich und Kompromiss angelegte und zudem stark verrechtlichte Verhandlungssysteme etabliert, werden im Rahmen von Organizing-Prozessen die Beschäftigten selbst zur aktiven Gestaltung der Interessenpolitik im Betrieb motiviert. Dabei kommt es zu einer bemerkenswerten beteiligungsorientierten Erweiterung des dualen Systems auf der betrieblichen Ebene. Durch Organizing-Prozesse werden sowohl die gewerkschaftlichen Organisationsstrukturen als auch die Betriebsräte in ihrem repräsentativen Politikmodus herausgefordert. Im Rahmen von Organizing-Prozessen etablieren sich betriebliche Aktivenkreise, die neben dem hauptamtlichen Personal der Gewerkschaft und den Betriebsräten aktiv die Interessenartikulation der Beschäftigten befördern und zugleich betriebspolitisches Engagement entfalten. Die Beschäftigten werden zu aktiven Gestaltern der betrieblichen Interessenpolitik und treten damit aus der weitgehend passiven Rolle heraus, die sie im dualen System einnehmen. Das stellt insbesondere die Betriebsräte vor eine Herausforderung, weil damit eine Veränderung ihrer Interessenvertretungspraxis einhergeht. Sie sind nun mit der Planung und Durchführung von Beteiligungsprozessen konfrontiert, die viel Zeit und Ressourcen in Anspruch nehmen. Auch müssen sich die Betriebsräte mit den neu etablierten Aktivenkreisen auseinandersetzen, die eine unabhängige interessenpolitische Position im Betrieb einnehmen. Zudem wird über das Aufgreifen betrieblicher Konflikte und der damit einhergehenden Mobilisierung der Belegschaft die betriebliche Interessenvertretungspraxis um eine konfliktäre und aktivistische Ausrichtung erweitert. Die Fallberichte dokumentieren, wie Organizing-Prozesse Belegschaften und Betriebsräte buchstäblich in soziale Bewegung versetzen. Wenn Betriebsräte die Organisierungsbestrebungen der Gewerkschaft unterstützen und zugleich Offenheit für die Beteiligung der Belegschaft mitbringen, kann dadurch eine betriebliche Bewegungsdynamik entfaltet werden, durch die die Legitimität und Durchsetzungsfähigkeit des Betriebsrates spürbar gestärkt werden. Damit zeigen die Fallstudien zunächst, dass der Bewegungscharakter des Organizing nicht notwendigerweise in Widerspruch zur formalisierten Interessenvertretung stehen muss, sondern viel mehr eine unterstützende und revitalisierende Wirkung auf letztere ausüben kann. Insbesondere die in enger Kooperation zwischen Betriebsrat und gewerkschaftlichen Aktivenkreis initiierte Beteiligung der Beschäftigten zu konkreten betrieblichen Themen festigt die Bande zwischen Betriebsrat und Belegschaft, wodurch die Legitimität des Betriebsrates und auch dessen Durchsetzungsfähigkeit gegenüber dem Management gestärkt werden können. So wurden zur Unterstützung der Betriebsräte (auch wenn darin nicht das eigentliche Ziel des Organizing-Prozesses besteht) Momente sozialer Bewegung genutzt, bei denen die Beschäftigten in der Interessenartikulation, dem Verhandlungsverlauf sowie in der Planung der Konfliktführung beteiligt und auch zu direkter Konfrontation der Geschäftsleitung mobilisiert wurden. Diese Formen der Konfliktführung im Sinne sozialer Bewegungen wurden bewusst neben oder auch als Kompensation zu nicht vorhandenen, bzw. als nicht wirkungsvoll wahrgenommenen verrechtlichten Verhandlungswegen angewandt, die für das duale System so charakteristisch sind. Der Fallbetrieb Generator zeigt dieses Wechselverhältnis sehr eindrücklich: Nachdem die Geschäftsleitung ohne Einbeziehung des Betriebsrates ankündigte, das Mittagessen zu streichen, stellte der Betriebsrat nicht nur die obligatorische Anfrage bei der Geschäftsleitung, sondern unterstützte darüber hinaus die Mobilisierung der 
Belegschaft zu einer Kundgebung, mit der die Unternehmensleitung unmittelbar mit der Forderung der Belegschaft konfrontiert werden sollte. Die Unternehmensleitung zeigte sich überrascht und sah sich genötigt, die Wiedereinführung des Mittagessens anzukündigen und sicherte zudem die Einbeziehung des Betriebsrates in dieser Frage zu. Tatsächlich wurde der Betriebsrat entsprechend einbezogen und erwirkte eine Verbesserung des Essensservice, der auf weitere Schichten ausgeweitet wurde. Dieser Fall zeigt, dass die institutionalisierten Verhandlungswege des dualen Systems auch missachtet und damit unwirksam sein können. Durch das Ausweichen auf andere Formen der Konfliktbearbeitung gelang es aber offensichtlich, den Betriebsrat wieder ins Spiel zu bringen und die Geschäftsleitung dazu zu bewegen, den Betriebsrat als Verhandlungspartner zu akzeptieren.

Die Fallstudien weisen darüber hinaus aus, dass die Bewegungs- und Beteiligungsdynamik im Rahmen von Organizing-Prozessen dort am stärksten war, wo zu Beginn eines Organisierungsprozesses entweder keine oder nicht arbeitsfähige Strukturen der Interessenvertretung bestanden. Hier griffen gewerkschaftliche Aktive und Betriebsräte aufgrund der fehlenden oder als nicht wirksam wahrgenommenen institutionellen Ressourcen auf die breite Beteiligung und Mobilisierung der Belegschaft zurück und nutzen deren aktivierende Wirkung zur Öffnung des betrieblichen Feldes. Offenbar bestand unter den Bedingungen institutioneller Schwäche eine größere Bereitschaft der betrieblichen Akteure, sich einer Organizing-Bewegungsdynamik zu öffnen. Zudem deuten die Ergebnisse der zugrundeliegenden Untersuchung darauf hin, dass die Bewegungselemente des Organizing-Ansatzes häufig nur vorübergehend genutzt wurden, um als betriebspolitische Initialzündung einer gewerkschaftlichen Organisierungsbewegung in den Betrieben zu dienen. Sobald über sogenannte Aktivenkreise erfolgreich gewerkschaftlich Aktive im Betrieb aufgebaut worden waren, wurden diese - mal mehr mal weniger zügig - in Vertrauensleutestrukturen überführt, deren fähigste Köpfe in einigen Fällen auch zu Betriebsräten wurden. Die Organizing-Elemente spielten demnach also insbesondere in Kontexten schwach entwickelter institutioneller Machtressourcen eine zentrale Rolle, weil die Aktivenkreise dann in einem interessenpolitischen Vakuum intervenieren konnten. Über die breite Beteiligung und Mobilisierung der Belegschaften wurde dann eine Bewegungsdynamik genutzt, die sich deutlich von den Verhandlungssystemen des dualen Systems unterschied, interessanterweise aber letztlich zum Aufbau oder Erneuerung eben dieser Institutionen der Interessenvertretung beitrug. Am Ende der untersuchten Organizing-Prozesse wurden schließlich mit arbeitsfähigen Betriebsräten und in drei der sechs Fallbetriebe auch mit einem abgeschlossenen Tarifvertrag erfolgreich die Basisinstitutionen des dualen Systems der Interessenvertretung etabliert.

Im Spiegel der Mitbestimmungsforschung stellen diese Ergebnisse keine gänzlich neue Entwicklung dar. Eine starke Orientierung der Betriebsräte auf die Belegschaft und die strategische Nutzung deren Mobilisierung hat bereits Kotthoff (1994) in seinen klassischen Betriebsrätestudien ausgemacht. Die enge Bindung des Betriebsrats an die Belegschaft besteht demnach allerdings nur bei einer Minderheit der Betriebsräte, die eine Gegenmachtorientierung aufweisen. Für diesen Betriebsratstyp hat auch Kotthoff enge Kooperationsbeziehungen mit der Gewerkschaft festgestellt, wie sie für die hier untersuchten Fallbetriebe ebenfalls konstitutiv war. Bemerkenswert ist, dass die Gewerkschaften im Rahmen von Organizing-Projekten die entscheidenden Impulse in Richtung einer auf die Beteiligung der Be- 
schäftigten ausgerichteten betrieblichen Interessenvertretung geben und damit klar im Regulierungsbereich der Betriebsräte intervenieren. Mit dieser Ausrichtung stoßen sie bei fest etablierten Betriebsratsgremien durchaus auf Widerstand. Offenheit gegenüber dem beteiligungs- und konfliktorientierten Organizing-Ansatz besteht dagegen in Betrieben mit isolierten und vertretungsschwachen Betriebsräten bzw. in Betrieben ohne Betriebsrat. Unter diesen Bedingungen wird die Beteiligung und Mobilisierung als zusätzliche Machtquelle genutzt, um die Betriebsräte überhaupt arbeitsfähig zu machen und damit die Interessenvertretungswirksamkeit herzustellen, die im Rahmen des dualen Systems der Interessenvertretung zwar angelegt ist, aber von den Akteuren unter den konkreten betrieblichen Zusammenhängen erst mit Leben erfüllt werden muss. Organizing-Projekte können insofern einerseits als pfadkonforme Erneuerungsstrategie verstanden werden, weil sie deutlich auf die Etablierung der Basisinstitutionen des dualen Systems ausgerichtet sind. Andererseits werden im Rahmen von Organizing-Projekten, die durch starke Bewegungsmomente charakterisiert sind, klar pfadfremde Strategien angewandt, die es erlauben, mit Lowell Turner von einer „dialectic between institutions and activism“ (Turner, 2009, S. 309) zu sprechen, wonach institutionelle Arrangements immer wieder einer Aktualisierung durch Basismobilsierungen bedürfen, um tatsächlich wirksam zu sein.

\section{Literatur}

Asshoff, G. (2014). Innere Rechtsverfassung der DGB-Gewerkschaften. In W. Schroeder \& S. Greef (Hrsg.), Handbuch Gewerkschaften in Deutschland (2. Aufl., S. 265-282). Wiesbaden: VSSpringer. doi: 10.1007/978-3-531-19496-7_11

Behrens, M. (2005). Mitgliederrekrutierung und institutionelle Grundlagen der Gewerkschaften. Deutschland im internationalen Vergleich, in: Berliner Debatte Initial, 16 (5), 30-37.

Bergmann, J. (1979). Organisationsstruktur und innergewerkschaftliche Demokratie. In J. Bergmann (Hrsg.), Beiträge zur Soziologie der Gewerkschaften (S. 210-239). Frankfurt am Main: Suhrkamp.

Birke, P. (2010). Die große Wut und die kleinen Schritte. Gewerkschaftliches Organizing zwischen Protest und Projekt. Berlin, Hamburg: Assoziation A.

Bosch, A., Ellguth, P. \& Trinczek, R. (1999). Betriebliches Interessenhandeln (Band 1). Zur politischen Kultur der Austauschbeziehungen zwischen Management und Betriebsrat in der westdeutschen Industrie. Opladen.

Bremme, P. (2007). Respekt und bessere Jobs. Organizing im Hamburger Sicherheitsgewerbe. In P. Bremme, U. Fürniß \& U. Meinecke (Hrsg.), Never work alone. Organizing - ein Zukunftsmodell für Gewerkschaften (S. 194-217). Hamburg: VSA.

Bremme, P., Fürniß, U. \& Meinecke, U. (Hrsg.) (2007). Never work alone. Organizing - ein Zukunftsmodell für Gewerkschaften. Hamburg: VSA.

Brinkmann, U., Choi, H. L., Dörre, K., Holst, H., Karakayali, S. \& Schmalstieg, C. (2008). Strategic Unionism: Aus der Krise zur Erneuerung? Umrisse eines Forschungsprogramms. Wiesbaden: VS-Springer.

Choi, H.-L. (2008). Re-Thinking Justice for Janitors - Strategische Erneuerung der amerikanischen Dienstleistungsgewerkschaft SEIU. WSI-Mitteilungen, 61 (1), 11-17.

Davis, G. F., McAdam, D., Scott, W. R. \& Zald, M. N. (Hrsg.). (2005). Social Movements and Organization Theory. New York: Cambridge.

Dörre, K. (2010). Überbetriebliche Regulierung von Arbeitsbeziehungen. In F. Böhle, G. G. Voß \& G. Wachtler (Hrsg.), Handbuch Arbeitssoziologie (S. 873-912). Wiesbaden: VS-Springer. doi: 10.1007/978-3-531-92247-8_29 
Dörre, K. \& Schmalz, S. (2013). Einleitung: Comeback der Gewerkschaften? Eine machtsoziologische Forschungsperspektive. In S. Schmalz \& K. Dörre (Hrsg.), Comeback der Gewerkschaften? Machtressourcen, innovative Praktiken, internationale Perspektiven (S. 13-38). Frankfurt am Main, New York: Campus. doi: 10.3726/978-3-653-03187-4/5

Dörre, K. (2016). Die neue Konfliktformation. Klassen-Kämpfe in fragmentierten Arbeitsbeziehungen. Industrielle Beziehungen, 23 (3), 348-365.

Dribbusch, H. (2013). Nachhaltig erneuern. Aufbau gewerkschaftlicher Interessenvertretung im Windanlagenbau. In D. Wetzel (Hrsg.), Organizing. Die Veränderung der gewerkschaftlichen Praxis durch das Prinzip Beteiligung (S. 92-118). Hamburg: VSA-Verlag.

Ebbinghaus, B. \& Göbel, C. (2014). Mitgliederrückgang und Organisationsstrategien deutscher Gewerkschaften. In W. Schroeder \& S. Greef (Hrsg.), Handbuch Gewerkschaften in Deutschland (S. 207-239). Wiesbaden: VS-Springer. doi: 10.1007/978-3-531-19496-7_9

Frege, C. M. (2000). Gewerkschaftsreformen in den USA. Eine kritische Analyse des ,Organisierungsmodells'. Industrielle Beziehungen 7 (3), 260-280.

Gahan, P. \& Pekarek, A. (2013). Social Movement Theory, Collective Action Frames and Union Theory: A Critique and Extension. British Journal of Industrial Relations 51 (4), 754-776. doi: $10.1111 / \mathrm{j} .1467-8543.2012 .00912 . x$

Ganz, M. (2000). Ressources and Resourcefulness: Strategic Capacity in the Unionization of California Agriculture, 1959-1966. American Journal of Sociology, 105 (4), 1003-1062. doi: $10.1086 / 210398$

Gumbrell-McCormick, R. \& Hyman, R. (2014). Trade Unions in Western Europe. Hard Times, Hard Choices. Oxford: University Press.

Hälker, J. \& Vellay, C. (2007). (Hrsg.). Union Renewal - Gewerkschaften in Veränderung. Düsseldorf: Hans-Böckler-Stiftung.

Haipeter, T. \& Dörre K. (Hrsg.). (2011). Gewerkschaftliche Modernisierung. Wiesbaden: VS-Springer. doi: $10.1007 / 978-3-531-93332-0$

Haipeter, T. (2011). Einleitung: Interessenvertretungen, Krise und Modernisierung - über alte und neue Leitbilder. In T. Haipeter \& K. Dörre (Hrsg.), Gewerkschaftliche Modernisierung (S. 7-28). Wiesbaden: VS.-Springer. doi: 10.1007/978-3-531-93332-0_1

Hurd, R., Milkman, R. \& Turner, L. (2003). Reviving the American Labour Movement: Institutions and Mobilization. European Journal of Industrial Relations, 9 (1), 99-117. doi: $10.1177 / 0959680103009001453$

Hyman, R. (2007). How can trade unions act strategically? Transfer: European Review of Labour and Research, 13 (2), 193-210. doi: 10.1177/102425890701300204

Kelly, J. \& Frege, C. M. (2004). Conclusions: Varieties of Unionism. In C. M. Frege \& J. E. Kelly (Hrsg.), Varieties of unionism. Strategies for union revitalization in a globalizing economy (S. 181-197). New York: Oxford.

Kocsis, A., Sterkel, G. \& Wiedemuth, G. (Hrsg.). (2013). Organisieren am Konflikt. Tarifauseinandersetzungen und Mitgliederentwicklung im Dienstleistungssektor. Hamburg: VSA.

Kotthoff, H. (1994). Betriebsräte und Bürgerstatus. Wandel und Kontinuität betrieblicher Mitbestimmung. München, Mering: Rainer Hampp Verlag.

Markowitz, L. J. (2000): Worker Activism after successful Union organizing. New York: M.E. Sharpe.

McAdam, D., Tarrow, S. \& Tilly, C. (2003). Dynamics of Contention. New York: Cambridge University Press.

Milkman, R (2006). L.A. Story. Immigrant Workers and the Future of the U.S. Labor Movement. New York: Russel Sage Foundation.

Müller-Jentsch, W. (1997). Soziologie der Industriellen Beziehungen. Eine Einführung (2., erweiterte Aufl.). Frankfurt am Main, New York: Campus. 
Müller-Jentsch, W. (2017). Strukturwandel der industriellen Beziehungen. „Industrial Citizenship“ zwischen Markt und Regulierung (2. Aufl.). Wiesbaden: VS-Springer.

Nachtwey, O. \& Thiel, M. (2014). Chancen und Probleme pfadabhängiger Revitalisierung. Gewerkschaftliches Organizing im Krankenhauswesen. Industrielle Beziehungen 21 (3), 258-276.

Prott, J. (2013). Organizing als riskante gewerkschaftliche Erneuerungsstrategie. In A. Kocsis, G. Sterkel \& G. Wiedemuth (Hrsg.), Organisieren am Konflikt. Tarifauseinandersetzungen und Mitgliederentwicklung im Dienstleistungssektor (S. 235-256). Hamburg: VSA.

Rehder, B. (2008). Revitalisierung der Gewerkschaften? Die Grundlagen amerikanischer Organisierungserfolge und ihre Übertragbarkeit auf deutsche Verhältnisse. Berliner Journal für Soziologie, 18 (3), 432-456. doi: 10.1007/s11609-008-0029-0

Rehder, B. (2014). Vom Korporatismus zur Kampagne. Organizing als Strategie der gewerkschaftlichen Erneuerung. In W. Schroeder (Hrsg.), Handbuch Gewerkschaften in Deutschland (2. Aufl., S. 241-264). Wiesbaden: VS-Springer. doi: 10.1007/978-3-531-19496-7_10

Schmalz, S. \& Dörre, K. (Hrsg.) (2013). Comeback der Gewerkschaften? Machtressourcen, innovative Praktiken, internationale Perspektiven. Frankfurt am Main, New York: Campus.

Schmidt, R. \& Trinczek, R. (1991). Duales System: Tarifliche und betriebliche Interessenvertretung. In W. Müller-Jentsch (Hrsg.), Konfliktpartnerschaft. Akteure und Institutionen der industriellen Beziehungen (S.167-199). München, Mering: Rainer Hampp Verlag.

Schmidt, R. \& Trinczek, R. (1999). Der Betriebsrat als Akteur der industriellen Beziehungen. In W. Müller-Jentsch (Hrsg.), Konfliktpartnerschaft. Akteure und Institutionen der industriellen Beziehungen (3. Aufl., S. 103-128). München, Mering: Rainer Hampp Verlag.

Streeck, W. (2016). Von Konflikt ohne Partnerschaft zu Partnerschaft ohne Konflikt: Industrielle Beziehungen in Deutschland. Industrielle Beziehungen, 23 (1), 47-60.

Thünken, O. (2013). „Ja, dieses Anfassbare“. Wie Aktive den gewerkschaftlichen Strukturaufbau vorantreiben und die betriebliche Interessenvertretung bereichern. In D. Wetzel (Hrsg.), Organizing. Die Veränderung der gewerkschaftlichen Praxis durch das Prinzip Beteiligung (S. 127138). Hamburg: VSA.

Turner, L. (2009). Institutions and Activism: Crisis and Opportunity for a German Labor Movement in Decline. Industrial and Labor Relations Review, 62 (3), 294-312. doi: 10.1177/001979390906200302

Voss, K. \& Sherman, R. (2000). Breaking the Iron Law of Oligarchy: Union Revitalization in the American Labor Movement. In: American Journal of Sociology, 106 (2), 303-349. doi: $10.1086 / 316963$

Wetzel, D. (Hrsg.). (2013). Organizing. Die Veränderung der gewerkschaftlichen Praxis durch das Prinzip Beteiligung. Hamburg: VSA. 


\section{Annett Schulze, Wolfgang Hien, Ernst von Kardorff \\ Der Beitrag der Neuen Sozialen Bewegungen zum Arbeits- und Gesundheitsschutz - eine Fallstudie zur Transformation und Verstetigung von Protestkommunikation in (in-)formellen Netzwerken ${ }^{* *}$}

\section{Zusammenfassung}

Der betriebliche Arbeits- und Gesundheitsschutz ist ein wichtiger Bestandteil gewerkschaftlichen Handelns und spielt bei den Aushandlungsprozessen um Arbeitsbedingungen durchaus eine Rolle. Nachhaltige Beschäftigungssicherung ist zudem ein Interesse, das rechtlich (bspw. im Kontext der Gefährdungsbeurteilungen) und politisch von Arbeitnehmer- wie von Arbeitgeberseite adressiert wird. Der vorliegende Beitrag stellt anhand einer Fallstudie zum Verein Arbeit \& Gesundheit e.V. dar, inwiefern die Neuen Sozialen Bewegungen den Arbeits- und Gesundheitsschutz auf die Agenda von Gewerkschaften, aber auch von Interessenvertretungen und anderen betrieblichen Akteur_innen in arbeitsregulativen Prozessen setzten. Zentrales Anliegen ist es herauszuarbeiten, wie sich Protestkommunikation zu einer auf Dauer angelegten Kommunikation über den betrieblichen Arbeits- und Gesundheitsschutz formieren und so die Position in den Auseinandersetzungen um Arbeitsbedingungen stärken konnte. Dafür war der Aufbau (in-)formeller Netzwerkstrukturen, eine juristische Absicherung des Akteursstatus, das Aneignen von Fachwissen und das Schaffen von Plausibilitätszonen, die für Gewerkschaften relevant wurden, eine zentrale Voraussetzung.

Schlagwörter: (In)formelle Netzwerke, Neue Soziale Bewegungen, Protestkommunikation, Arbeits- und Gesundheitsschutz

* Dr. Annett Schulze, Humboldt-Universität zu Berlin, FB Rehabilitationswissenschaften, 10099 Berlin. E-Mail: annett.schulze@hu-berlin.de

Dr. Wolfgang Hien, Humboldt-Universität zu Berlin, FB Rehabilitationswissenschaften, 10099 Berlin. E-Mail: kontakt@wolfgang-hien.de

Prof. i.R. Dr. Ernst von Kardorff, Humboldt-Universität zu Berlin, KSB-Fakultät, Institut für Rehabilitationswissenschaften, 10099 Berlin. E-Mail: ernst.von.kardorff@rz.hu-berlin.de

Für wertvolle Hinweise in der Diskussion des Beitrags danken wir unserem Kollegen Sascha Blasczyk.

** Artikel eingegangen:31.8.2017

revidierte Fassung akzeptiert nach doppelt-blindem Begutachtungsverfahren: 3.3.2018 


\section{New social movements and health and safety at work. A case study on the transformation and institutionalisation of protest communication in (in)formal networks}

Abstract

Health and safety at work is increasingly at the centre of trade union actions and negotiations concerning employment conditions. Furthermore, sustainable job security is of political and legal interest that needs to be addressed by employers and employees alike. The following article, based on a case study of the Verein Arbeit \& Gesundheit e.V., considers to what extent new social employment as well as health and safety movements are influencing union agendas, employee representative bodies as well as plant actors' regulative procedures. A central consideration of this paper concerns how protest communication can be transformed into a lasting communication structure dealing with employment as well as health and safety issues able to make a strong contribution to disputes surrounding employment conditions. A precondition of this is the creation of informal and formal structures, legally securing actors' status, the appropriation of professional expertise and the creation of plausibility zones relevant to trade unions.

Key words: (in)formal networks, new social movements, protest communication, health and safety at work (JEL: I 18, J 81, L 31)

\section{Einleitung}

Eine der Fragen unseres Projektes „,,Neue Allianzen“ für ,Gute Arbeit‘ mit bedingter Gesundheit - nachhaltige Beschäftigungssicherung durch Kooperation betrieblicher und außerbetrieblicher Akteure "1 richtet sich darauf, inwieweit und auf welche Weise eine nachhaltige Beschäftigungssicherung gesundheitlich beeinträchtigter Arbeitnehmer_innen erreicht werden könnte - und zwar durch eine veränderte Regulierung von Arbeitsbeziehungen unter Nutzung der Synergieeffekte bestehender Netzwerke und der Schaffung neuer Allianzen.

Neue Ideen und neue Praxen in Vernetzungen sind oft auch das Ergebnis von Protest sozialer Bewegung(en). Hier bildet der Arbeits- und Gesundheitsschutz keine Ausnahme. In der Forschung bisher wenig beachtet, spielen Neue Sozialen Bewegungen (im Folgenden NSB; vgl. Roth \& Rucht, 2008) eine gewichtige Rolle dabei, wenn es um Innovationen in der Arbeitsregulation geht. So zeigen sich bei einer Analyse der Entwicklung und Inhalte etablierter Netzwerke und institutioneller Akteure im Feld des Arbeits- und Gesundheitsschutzes immer wieder Spuren von Protest, von Impulsen und Einflüssen der NSB, insbesondere der Gesundheits(laden)bewegung. Von Bedeutung sind insbesondere im Arbeitsund Gesundheitsschutz spezifische Akteur_innen, die als Knowledge Broker, verstanden sowohl als einzelne Akteure als auch als Organisationen, dafür sorgen, dass Wissen geschaffen, geteilt, verstanden und genutzt werden kann (Meyer, 2010, S. 119).

1 Das Projekt ist Teil des Forschungsverbundes „Neue Allianzen für Gute Arbeit bei bedingter Gesundheit“, gefördert von der Hans-Böckler-Stiftung. 
Ein weiterer Grund für die historische Vergleichsperspektive ist, dass Teile der NSB die Idee einer ganzheitlichen Betrachtung der gesundheitlichen Situation von Beschäftigten unter dem Aspekt des Gesundheitsschutzes in die Programmatiken und Praxis etwa der Deutschen Gesetzlichen Unfallversicherung (DGUV) und der Gewerkschaften einbrachten.

Anhand einer Fallstudie zum Verein Arbeit \& Gesundheit e.V. und dessen Beratungsstelle in Hamburg möchten wir daher beispielhaft zeigen, welchen Beitrag Akteur_innen der NSB zum Arbeits- und Gesundheitsschutz geleistet haben. Uns interessieren insbesondere die Bedingungen der Verstetigung, die ein anlassbezogenes oder zeitlich befristetes Protestthema zu einer auf Dauer angelegten Aufgabe transformieren. Grundlage der Analyse sind Expert_innengespräche, die Annett Schulze mit einigen zentralen, teilweise bis heute aktiven, Akteur_innen aus der Entstehungszeit von Arbeit \& Gesundheit e.V. führen konnte. Für deren Zeit und Auskunftsbereitschaft möchten wir uns hier bedanken. ${ }^{2}$

Den Verein Arbeit \& Gesundheit e.V. gründeten offiziell im Jahr 1987 u.a. Engagierte aus der Gesundheitsladenbewegung. Der Verein ist heute institutioneller Träger einer Beratungsstelle, die Betriebe zu Fragen des Gesundheitsschutzes und zur Prävention arbeitsbedingter Erkrankungen berät. Hier finden Betroffene zudem Unterstützung in Anerkennungsverfahren zu Berufskrankheiten und bei Arbeitsunfällen. Seit 2016 trägt der Verein zudem die Perspektive Arbeit \& Gesundheit (PAG) eine Anlaufstelle zur Beratung von Beschäftigten und Betrieben mit dem Ziel, Arbeit gesundheitsgerecht zu gestalten und psychische Gefährdungen in den Blick zu nehmen.

Nach einer theoretischen Einbettung werden wir zunächst den historischen Kontext darstellen, in dem sich die Gesundheitsladenbewegung formierte. Anhand der erhobenen Interviews wird herausgearbeitet, wie die Befragten rückblickend das Verhältnis zu den jeweils anderen Akteur_innen von Beginn an bis heute beschreiben, reflektieren, aber auch rekonstruieren, rationalisieren und legitimieren. Daraus wird exemplarisch abgeleitet, inwiefern sich die Protestkommunikation des Hamburger Gesundheitsladens zu einer auf Dauer angelegten Gesundheitskommunikation in einem rechtlich institutionalisierten Verein entwickeln konnte. Hier bereichern wir mit einer systemtheoretisch orientierten kommunikationswissenschaftlichen Perspektive bisherige Forschungen zu sozialen Bewegungen und skizzieren, inwiefern die Position des Knowledge Brokers (u.a. Meyer, 2010) und die Frage nach Frame-Resonanzen auch für die Analyse von Verstetigungsaspekten jenseits des Austausches innerhalb Sozialer Bewegungen oder aber jenseits des Blicks auf das Verhalten einer NSB gegenüber Gegnern (Benford \& Snow, 2010) hilfreich ist. Abschließend formulieren wir Überlegungen dazu, wie Arbeits- und Gesundheitsschutz als unverzichtbarer Bestandteil betrieblicher Arbeitsregulation strategisch über neue Allianzen u.a. mit gewerkschaftlicher Interessenvertretung und außerbetrieblichen Akteuren verankert werden sollte.

2 Für die gezogenen Schlussfolgerungen trägt das Autor_innenteam die Verantwortung. 


\section{Neue Ideen der NSB auf ihrem Weg in institutionalisierte Routinen - eine netzwerkanalytische Perspektive}

Die Anregung zu neuen Allianzen für eine verbesserte und nachhaltige betriebliche Gesundheitspolitik wirft Fragen auf: nach Bündnispartnern, Kooperationsformen und nach Barrieren, die aus den Eigenlogiken der handelnden Bezugsgruppen resultieren. Zunächst rücken dabei Kommunikations- und Aushandlungsprozesse in und zwischen informellen und formellen Netzwerken in den Blick, die als soziales Gewebe verstanden werden. Die darin geschaffenen Verbindungslinien transportieren Ziele, Inhalte und Verfahren zu den fester gefügten Organisationsstrukturen auf der einen und zu den diffusen sozialen Bewegungsakteuren auf der anderen Seite. Austausch- bzw. Transformationsprozesse (Meyer, 2010, S. 123) auf diesen Verbindungslinien können auch im arbeitsregulativen Feld der betrieblichen Gesundheitspolitik beobachtet werden. Die NSB der 1970er-Jahre setzten nicht nur Impulse für die staatliche Gesundheitspolitik (Lienert, 2009, S. 22f), sondern beeinflussten auch auf betrieblicher Ebene den Arbeits- und Gesundheitsschutz und damit einen Teil arbeitsregulativer Bestimmungen vor Ort, wie es dieser Beitrag thematisiert.

Dabei kristallisieren sich zwei analytisch interessante Dimensionen heraus: erstens kommunikative Aushandlungsprozesse in asymmetrischen Strukturen und zweitens Prozesse der rechtlichen Regulierung, die mit Legitimationsgewinn oder -verlust verbunden sein können. Aus einer Aushandlungsperspektive sind Fragen der Mobilisierung angesprochen: Wer kann welche Ressourcen aufbringen? Welche Rolle spielen dabei Ideen und Wissen, die von Knowledge Brokern nicht nur weitergegeben, sondern auch transformiert werden? Und inwiefern sind hier in-/formelle Vernetzungen von Bedeutung?

Die Akteur_innen der NSB haben das Thema Arbeits- und Gesundheitsschutz im Anschluss an die Programme zur Humanisierung des Arbeitslebens (u.a. Raehlmann, 2015, S. 103-114) erneut und aus einer neuen Perspektive auf die gewerkschaftliche Agenda gebracht. Dass dies gelingen konnte, ist als Resultat einer „losen Kopplung“ (Weick, 1985) von Akteur_innen der NSB, die zugleich Gewerkschaftsmitglieder (,Alte Soziale Bewegung") waren, mit gewerkschaftlichen Strukturen interpretierbar. Die Aushandlungsprozesse zwischen den damaligen Akteur_innen innerhalb von Gewerkschaften und im Betriebsrat (BR) einerseits und in Gesundheitsläden andererseits zeigen, inwiefern die unterschiedlichen Systemtypen der institutionalisierten Organisation und der Bewegung sich in einem günstigen historischen Zeitfenster gegenseitig trotz aller vorgegebenen Reibungsflächen Ermöglichungsräume schaffen konnten (Tratschin, 2016, S. 24). So boten Gewerkschaften den NSB Stabilität, forderten aber zugleich als etablierte Institution die Anerkennung institutioneller Entscheidungswege und -hierarchien. Im sozialpartnerschaftlich verhandelten und gesetzlich geregelten Arbeits- und Gesundheitsschutz zeigt sich dies u.a. in der Anforderung, sich Fachwissen anzueignen, sich zu professionalisieren und letztlich sich zu spezialisieren. Umgekehrt schuf die Gesundheitsladenbewegung mit ihren Gruppen des betrieblichen Arbeits- und Gesundheitsschutzes den Gewerkschaften Optionen auf eine neue Legitimität unter Arbeitnehmer_innen.

Gleichzeitig kann das Verhältnis von Gewerkschaften zu den NSB als ambivalent charakterisiert werden: Die deutschen Gewerkschaften sind aufgrund ihrer gewachsenen institutionalisierten Versäulung stark an feste Organisationsstrukturen und -abläufe sowie an 
komplexe, mitunter komplizierte Abstimmungsprozeduren gebunden. Das erschwert, sich den Ideen eines Social Movement Unionism ${ }^{3}$ und damit der Bündnisbildung mit sozialen Bewegungen zuzuwenden (Fichter, Gester \& Zeuner, 2004, S. 135-136). Die ausgeprägte Formalisierung führt dazu, eher dem Glauben an Einfluss und der Logik von Führung im Sinne eines Sicherns erkämpfter Positionen zu folgen. Gleichzeitig geraten Mitgliederdiskussionen von unten und von dort artikulierte Dringlichkeiten und Themen oder engagierte Perspektiven von außen aus dem Blick. Denn für bürokratisch institutionalisierte kollektive Akteure wie Gewerkschaften und für formelle Netzwerke gelten Satzungen und andere Mitgliedschaftsregeln. An den Schnittstellen zu informellen Netzen treffen unterschiedliche Verhaltenskodizes, Sprachregelungen und historisch gewachsene Normierungen aufeinander. Diese bilden eine Gemengelage, die eine Transformation von Begriffen, Konzepten und Strategien durchaus ermöglicht und damit Prozesse des Wandels begünstigen kann.

Im Vergleich zur Institution Gewerkschaft lassen sich soziale Bewegungen als ,,soziale Gebilde aus miteinander vernetzten Personen, Gruppen und Organisationen (darstellen), die (...) mit gemeinsamen Aktionen Protest ausdrücken, um soziale beziehungsweise politische Verhältnisse zu verändern“ (Rucht \& Neidhardt, 2007, S. 634). NSB grenzen sich von den ,alten sozialen Bewegungen“ wie der Arbeiterbewegung, die sich heute mehrheitlich in Gewerkschaften institutionalisiert haben, dadurch ab, dass sie vielfältig, spontan und dezentral agieren sowie sich in informellen und formellen Netzwerken auf lokaler und überregionaler Ebene zusammenschließen (Rucht, 1993, S. 364, eine schematische Übersicht bietet Kardorff, 1996, S. 29). ${ }^{4}$

Aus einer systemtheoretisch geleiteten kommunikationswissenschaftlichen Sicht lassen sich soziale Bewegungen ,als ein Typus sozialer Systeme“ verstehen (Tratschin, 2016, S. 35). Um Kristallisationspunkte für Mobilisierung und Engagement zu schaffen, Wirkung zu erzeugen und sich zu stabilisieren, tendieren die Vernetzungen in den sozialen Bewegungen zunehmend zur Ausbildung formaler Strukturen mit Organisationskernen und zu Formen selbstreferentieller Kommunikation. Daraus resultiert eine auf die Binnenstrukturen gerichtete Problemselektion. Die entstehenden Selbstbeschreibungen bilden eine spezifische Einheit und grenzen die neu geschaffene Netzwerkformation gegenüber anderen Phänomenen bzw. Systemen ab (Tratschin, 2016, S. 75). Soziale Bewegungen verkörpern somit nicht nur mobilisierende Netzwerke, sondern sind auch ,selbstreferentielle Kommunikationszusammenhänge“" (Tratschin, 2016, S. 12), die soziale Ordnungsformen hervorbringen und Sinn stiften können.

Ein kollektivpsychologisch wichtiges Element der Selbstbeschreibungen sozialer Bewegungen stellt die identitätsbildende Protestkommunikation dar, die erst durch Institutionalisierungsprozesse zu einer auf Dauer angelegten Kommunikation werden kann und unterschiedliche System-Umwelt-Differenzen produziert. Protest wird hier als eine Form der Kommunikation verstanden, die an andere adressiert ist und an deren Verantwortung appelliert (Luhmann, 1991, S. 135); diese also zum Handeln bewegt werden sollen. Der Protest

3 Unter Social Movement Unionism lassen sich neue Formen der Zusammenarbeit und gemeinsamer Aktionen der Gewerkschaften mit sozialen Bewegungen, Bürgerrechtsinitiativen etc. fassen. Moody (1997) geht davon aus, dass sich so Gewerkschaften über diese Öffnung nach außen erneuern und als soziale Bewegungsakteurin revitalisieren.

4 Neuere Entwicklungen von bspw. digitalen Vernetzungsstrategien zeigt Winter (2017, S. 237-252) auf. 
stabilisiert sich qua Organisationsbildung und kann so über einen längeren Zeitraum kommuniziert werden. Dieses eher systemtheoretische Verständnis von sozialen Bewegungen erweitert die ursprüngliche Perspektive von Rucht (1993) auf soziale Bewegungen um die Dimension der Verstetigung. Denn die NSB bedienen sich nicht nur des Protestes als Ausdrucksform, sondern können selbst als ,Selektivitätsverkettungen von Protestkommunikationen“ verstanden werden (Tratschin, 2016, S. 37). Eine auf Dauer angelegte Kommunikation erfordert jedoch, dass die Akteur_innen letztlich nicht nur Verantwortung anmahnen, sondern selbst auch Verantwortung übernehmen, indem sie selbst für Lösungen sorgen. Diese systemtheoretisch basierte kommunikationswissenschaftliche analytische Perspektive wird in der tradierten Bewegungsforschung selten eingenommen (siehe u.a. Tratschin, 2016, S. 13f). Sie lässt aber Verstetigungsprozesse von Bewegungen hin zu institutionalisierten Akteur_innen über den Dreiklang der Zeit-(Bewegungsgeschichte), Sach- (Themenspezifikation) und Sozialdimension (Verantwortliche wie Publikum) analytisch begreifbar werden. Auf einer Metaebene werden hier dimensionale und kategoriale Überschneidungen oder Anknüpfungsmöglichkeiten zum Framing-Ansatz der Bewegungsforschung sichtbar, z.B. wenn es um Plausibilitätszonen und Diffusionsprozesse oder um Fragen der Adressat_innen und Publikumseffekte (Benford, \& Snow, 2000) geht.

Diese analytische Perspektive lässt sich auch auf die Frage nach der Verstetigung des Protestes gegen gesundheitsschädliche Arbeitsbedingungen in den 1970er- und 1980erJahren übertragen. Arbeitsregulation, so verstehen es Windeler und Wirth (2010, S. 585), sei „Medium und Resultat sozialer Kämpfe um Sets von Regeln und Ressourcen auf mehreren, miteinander verknüpften sozialen Ebenen“. Wie wir zeigen werden, haben Ideen der NSB eine bedeutsame Rolle bei der Veränderung dieser Sets im Arbeits- und Gesundheitsschutz gespielt. Beteiligt waren daran vor allem Akteur_innen, die sich oft zugleich in den Gesundheitsläden, der Umwelt- und Anti-Atom-Bewegung engagierten und zudem über arbeitsregulatives Wissen verfügten wie Betriebsräte oder Arbeitsmediziner_innen. Diese Mehrfachmitgliedschaften ermöglichten, zu wichtigen vermittelnden und Brücken bauenden Schlüsselpersonen (Brokern) zu werden.

Für das Verständnis dieser Veränderungen sind erstens die Selbstverortungen der Akteur_innen von Interesse, die über ihre je eigenen Formen von semantischer und symbolischer Politik verfügen, mit deren Hilfe sie Sinnzusammenhänge, Momente der Zugehörigkeit oder des Dissenses definieren. Entscheidend sind zweitens die Themenwahl, deren Rahmungen und die gewählten Ereignisse, die ausschlaggebend für Kommunikationshandlungen wie Protest waren. Bedeutsam sind drittens die Adressat_innen, an die sich der Protest richtet - einerseits die Verantwortlichen für den Missstand und andererseits das Publikum selbst, das entweder betroffen ist oder sich potenziell mit den Betroffenen solidarisieren könnte.

Die Verstetigung eines Teils der Hamburger Gesundheitsladenbewegung als eine Bewegung durch die Zeit zu verstehen, in der jeweils andere Akteur_innen, Konstellationen und Funktionen wirksam werden, zeichnen wir anhand der Entwicklung des Vereins Arbeit \& Gesundheit e.V. vorrangig aus der Binnenperspektive der beteiligten Akteur_innen nach. Die Grundlage der qualitativen Inhaltsanalyse bilden zehn Expert_inneninterviews, deren Aussagekraft durch die Auswahl der Interviewten, durch den Blick zurück aus der heutigen Position und gegenwärtiger Problemstellungen sowie durch die subjektive Erinnerung be- 
stimmt ist. Erfasst werden können nur ihre aktuellen Perspektiven auf das, was von den Befragten als entscheidende Ereignisse und Akteur_innen erinnert wird. Dennoch haben wir mit den unterschiedlichen lokalen und überregionalen Akteur_innen aus dem Gesundheitsladen, dem Deutschen Gewerkschaftsbund (DGB), der Hamburger Kooperationsstelle Hochschulen/Gewerkschaften, einem BR und dem Verein Arbeit \& Gesundheit e.V. eine Multiperspektivität gesichert, die ein kritisches Gegenlesen der unterschiedlich gerahmten Erinnerungen ermöglicht. ${ }^{5}$

Zunächst soll nun der Verein Arbeit \& Gesundheit e.V. historisch eingeordnet werden. Dabei liegt der Fokus auf der Gesundheits(laden)bewegung und ihrem Verhältnis zu Umwelt und Betrieb.

\section{Die Gesundheitsbewegung und Betriebsarbeit in der BRD}

Die Gesundheitsbewegung der 1970er- und 1980er-Jahre war von Erfahrungen auf ganz verschiedenen Ebenen geprägt. Die 68er-Bewegung protestierte gegen die autoritär geprägten gesellschaftlichen Strukturen. Sichtbar wurden die Schatten des Wirtschaftswunderlandes, in dem Härte, Durchhaltevermögen und sozialdarwinistische Haltungen noch zu den vorherrschenden Tugenden gehörten (Hien, 2017). ${ }^{6}$ Den Medizinbetrieb prägten alte Eliten, für die Leistungsfähigkeit den Wert des Menschen bestimmte - eine Mischung aus erbbiologischer Tradition, selektionsmedizinischer Klassifizierung und naturwissenschaftlichem Tunnelblick führte zum isolierenden und organzentrierten Blick der Klinik, wie Foucault (1973) dies beschrieben hat. Behandelt wurde die Lunge, das Herz oder die Haut; vernachlässigt wurde der erkrankte Mensch in seiner umfassenden psycho-sozialen und leiblichen Verfasstheit wie in seiner lebensweltlichen Verortung. Den Protest rahmten die Kritik an der herrschenden Medizin sowie an den industriell hergestellten Gesundheitsrisiken und die Entwürfe einer alternativen Medizin (zur Auseinandersetzung innerhalb der Medizin: Kemper, 2016, S. 111-121). ${ }^{7}$

Das Menschenbild in der Arbeitswissenschaft war zu jener Zeit noch geprägt vom Arbeiter als ,economic man“, der prinzipiell nach seiner Wirtschaftlichkeit beurteilt wurde (Ulich, Zink \& Kubek, 2013, S. 18) und Arbeitsmedizin als Leistungsmedizin verstand. Betrieblicher Erfolg wurde gleichgesetzt mit neuen, als effizienter geltenden Verfahren, deren Konsequenzen noch gar nicht abzuschätzen waren. Die Ansichten der praktisch tätigen Betriebsärzte reichten vom Standpunkt, geschädigte Arbeiter_innen schlicht durch widerstandsfähigere zu ersetzen bis hin zur Erweiterung der Hygienevorschriften (Böschen, 2013, S. 197f).

Seit den 1970er-Jahren zeichnete sich eine verstärkte Diffusion chemischer Technologien in klassische Branchen ab. Neben der flächendeckenden Massenverwendung von Pestiziden in der Landwirtschaft erlebten weitere Bereiche eine Chemisierung (Köhler, 1983):

5 Aufgrund der getroffenen Vereinbarungen werden die Interviews anonymisiert. Archiviert sind diese im Rahmen des Projektes an der Humboldt-Universität zu Berlin.

6 Eine ausführlichere Darstellung findet sich bei Hien (2017).

7 Hier wären Fragen des Diagnostic, Prognostic und Motivational Framing für die Bewegungsforschung ergiebig, die zudem aufzeigen, inwiefern Framing als dynamischer Prozess soziopolitisch und -kulturell eingebettet ist (Benford \& Snow 2000, S. 627). 
PVC und Kunststoffe auf Polyester- und Epoxid-Basis im Maschinenbau, der Elektrotechnik und vielen weiteren Bereichen, chlorierte Kohlenwasserstoffe in der bergbaulichen Hydraulik, Polyurethan-Lacke, -Kleb- und -Dichtstoffe auf Isocyanat-Basis in der Automobilindustrie, im Karosseriebau und im Kfz-Handwerk, ebensolche Stoffe in der Holzindustrie und im Tischlerhandwerk (siehe Datenbanken der Kooperationsstelle Hamburg IFE, 2017). Die Seveso-Katastrophe im Jahr 1976 (Böschen, 2000, S. 217-227; zu den Auswirkungen: Bertazzi, Bernucci, Brambilla, Consonni \& Pesatori, 1998) und das Bekanntwerden der „PVC-Krankheit“" hatten den Blick geschärft.

Diese - hier nur ausschnitthaft und kursorisch angesprochenen - Hintergründe waren es, die zur Gründung von Umweltgruppen, Wissenschaftsläden, einschlägigen Arbeitsgruppen in den Gesundheitsläden, Betriebsgesundheitsgruppen und weiteren Initiativen führten, die ,Gesundheit' auch als politische Kategorie perspektivierten. Zu einem Katalysator wurden zudem die Ideen der italienischen Arbeiterbewegung (Wintersberger, 1978, 1988). Ein gemeinsames Ziel der ansonsten sehr heterogenen Initiativen war es, eine eigenständige Bearbeitung der arbeitsbedingten Gesundheitsrisiken aufzubauen - die „Arbeitermedizin“. Nicht die Arbeit sollte geschützt werden, sondern die Arbeiter_innen. Nicht an die Betriebsärzte und den Medizinbetrieb sollte die Gesundheit delegiert werden: Sie sollte in den Händen der Arbeiter_innen bleiben. „Non delegata“ war somit das zentrale Motto dieser Bewegung.

In den Gesundheitsläden kamen Aspekte der Arbeitswelt auf die Agenda. Es entstanden Arbeits- und Projektgruppen, die Kontakte zu gewerkschaftlichen und betriebspolitischen Gruppen suchten, die entweder bereits Themen arbeitsbedingter Gesundheitsrisiken aufgegriffen hatten oder zu diesen Themen ansprechbar waren. Erfolgreiche Kooperationen entwickelten sich in der gewerkschaftlichen Bildungsarbeit. In Berlin formierte sich 1980 aus Mitgliedern des Gesundheitsladens, gewerkschaftlichen Bildungsarbeiter_innen und Teilen des Kirchlichen Dienstes in der Arbeitswelt ein explizit dem Betrieb gewidmeter Kreis: der „Berliner Infoladen für Arbeit und Gesundheit“ (BILAG), der aufgrund seiner über Jahre erscheinenden „BILAG-Briefe“ bundesweit Bedeutung erlangte (Czock, Göbel \& Guthke, 1990). In den Gesundheitsläden Bochum, Frankfurt und Hamburg bildeten sich Arbeitskreise, die entweder den klassischen Beinamen „Arbeitsmedizin“, doch zunehmend den Titel „Arbeitermedizin“ trugen.

In Hamburg ging die Gründung der Grün-Alternativen Liste (GAL) und ihr Einzug in die Bürgerschaft 1982 einher mit dem Fokus auf umwelt- und arbeitsbedingte Gesundheitsrisiken, die mit dem Boehringer-Skandal $1984^{8}$ in Hamburg ihren vorläufigen Höhepunkt erreichten (GAL-Umweltgruppe, 1984). Der Hamburger Boehringer-Betrieb hatte in Moorfleet, einem Hamburger Stadtteil, jahrzehntelang Hexachlorcyclohexan und andere chlororganische Pestizide produziert, die sowohl innerhalb des Werkes als auch im angrenzenden Moorfleet zu gravierenden Dioxinvergiftungen führten. Bürgerinitiativen machten den Skandal öffentlich. Die GAL setzte das Thema auf die Agenda der Bürgerschaft und sorgte für die Werksschließung. Hauptbetroffene waren die Arbeiter_innen. Viele von ihnen waren bereits schwer erkrankt. Die Belegschaft wies u.a. eine signifikant erhöhte Krebssterblichkeit auf (Altenmüller, 2015). Der Arbeitsmediziner Alfred Manz leitete die vom Senat eingerichtete Beratungsstelle für die ehemaligen Boehringer-Arbeiter_innen,

8 Die Rolle der etablierten Arbeitsmedizin im Boehringer-Skandal griffen Medien kritisch auf (u.a. zu den Verstrickungen mit der Industrie: u.a. Hauch-Fleck, 1989). 
baute diese maßgeblich mit auf und prägte mit seinem Engagement für Erkrankte die Hamburger Arbeitsmedizin.

Im Kontext eines ökologisch sensibilisierten gesellschaftlichen Klimas gelang es, phasenweise im etablierten gewerkschaftlichen Bereich Einfluss zu gewinnen. Unter dem Motto „Tatort Betrieb“ begann die IG Metall Baden-Württemberg 1988 eine Kampagne gegen den Einsatz krebserzeugender Kühlschmierstoffe, die mit dem Thema Lösemittel und Nervenschädigungen durch Lösemittel fortgesetzt wurde (Leisewitz, 1992). Umweltschutz am Arbeitsplatz wurde in eins gesetzt mit Gesundheitsschutz am Arbeitsplatz. Die Aufnahme dieser kritischen Themen durch die IG Metall ist ein gutes Beispiel dafür, wie die Ideen und das Engagement der vielfältig, überwiegend informell, vernetzten Initiativen aus den NSB in die institutionalisierten Netzwerke der Gewerkschaften diffundierten und zu einem zunächst internen Mobilisierungseffekt führten.

1989 gründeten Ökologen, Gewerkschafter und politische Aktivist_innen die Zeitschrift Arbeit-und-Ökologie-Briefe, die thematisch und aktionsfördernd über viele Jahre in die Gewerkschaften und in die Betriebe hineinwirkten. Einzelne BR-Gruppen und gewerkschaftliche Vertrauensleute griffen die Themen auf und forderten, gefährliche Arbeitsstoffe und gefährliche Arbeitsverfahren zu ersetzen - Ansprüche, die das tradierte Gefüge der betrieblichen Machtverhältnisse in Wanken geraten ließen.

Unweigerlich hängen die Arbeitsbedingungen, die die Gesundheit der Beschäftigten gefährden oder schädigen, mit Fragen der Anerkennung von Berufskrankheiten durch die Berufsgenossenschaften (BGen) zusammen. Dies bildete einen entscheidenden Ausgangspunkt für die Gründung des Vereins Arbeit \& Gesundheit e.V. und dessen Beratungsstelle in Hamburg. Aktivist_innen, z.T. aus der Gesundheitsladen-Tradition, z.T. aus Umweltund Arbeitsschutzprojekten der damals noch existierenden Hochschule für Wirtschaft und Politik, schufen eine organisatorische Grundlage für eine längerfristig tragfähige Informations- und Beratungsstelle für Beschäftigte, die arbeitsbedingt belastet und erkrankt sind. Wie sich die Arbeitsgruppe innerhalb des Gesundheitsladens zum Verein Arbeit \& Gesundheit e.V. und den Beratungsstellen transformierte, welche Rolle dabei Gewerkschaften in den Vernetzungen spielten und inwiefern bestimmte kommunikative Handlungen, die Regulationen im Arbeits- und Gesundheitsschutz fokussierten, Veränderungen notwendig machten, soll im Folgenden rekonstruiert werden.

\section{$4 \quad$ Arbeit \& Gesundheit in Hamburg - NSB und zentrale Akteur_innen im Arbeits- und Gesundheitsschutz}

Die Geschichte von Arbeit \& Gesundheit e.V. steht für eine informelle Netzwerkstruktur, die sich inzwischen als eine vermittelnde Netzwerkstruktur etablieren konnte und die netzwerktheoretisch als Vermittlungsinstanz zwischen den Akteur_innen und Anliegen der NSB, gewerkschaftlicher Interessenvertretung und institutionalisiertem Arbeits- und Gesundheitsschutz fungiert. Damit konnten die Akteur_innen, agierend als Knowledge Broker, die „structural holes“ (Burt, 1992) zwischen diesen Bereichen mit ihren unterschiedlichen organisatorischen Verfasstheiten, Interessen und Wissensordnungen überwinden. Zudem gelang es den Akteur_innen durch die Vereinsgründung, die Protestkommunikation zu 
Gesundheitsschädigungen aufgrund von Gefahrstoffen in Betrieben in eine auf Dauer angelegte Kommunikation zu transformieren und damit wesentlich zu Fragen einer gesundheitspräventiven Arbeitsregulation Stellung zu nehmen.

Im Abschnitt 4.1 stehen historische Entwicklungslinien im Vordergrund. In 4.2 interessieren die Themenagenden und die Konfliktlinien in der sich transformierenden Protestkommunikation. In 4.3 zeigen wir, wie Verrechtlichungs- und Verwissenschaftlichungsprozesse zu einer auf Dauer angelegten Kommunikation in Regulationsfragen zum Arbeitsund Gesundheitsschutz werden.

\subsection{Geschichte der Beratungsstelle aus der Perspektive ihrer Mitbegründer_innen}

Die individuelle Lebensgeschichte bestimmte in den Interviews die Perspektive auf die Entstehung des Vereins. Ähnlich wie im Film „8 Blickwinkel“ (Moritz \& Travis, 2008), in dem ein Ereignis abhängig vom Standort der jeweiligen Akteurin oder des jeweiligen Akteurs erzählt wird und das begrenzte Blickfeld die Narration bestimmt, findet sich auch in unseren Interviews ein Kaleidoskop an Erinnerungen. Obwohl mehrere Interviewte betonten, dass es keine lineare Entwicklung in der Geschichte von Arbeit \& Gesundheit e.V. gab, sondern dessen heutige Rolle eher einer Reihe von historischen Zufällen und individuellen, mitunter spontan getroffenen Entscheidungen geschuldet ist, so lassen sich dennoch Stationen herausarbeiten, die für die Sicherung einer auf Dauer angelegten Gesundheitskommunikation in den Bereichen der Arbeitsregulation bis heute bedeutsam geblieben sind.

Institutionalisierungsprozesse kennzeichneten die Entwicklungen in vielen NSB, zuweilen als „Marsch durch die Institutionen“ propagiert wie kritisiert. Akteur_innen, die sich unterschiedlichen Bewegungen zugehörig fühlten, bildeten die Basis für die Verstetigung des Engagements der Arbeitsgruppe (AG) Arbeitermedizin, die später im Gesundheitsladen Hamburg ihren Ort fand. Dem voraus ging der erste Gesundheitstag in Berlin an Pfingsten 1980 - maßgeblich initiiert von dem Arzt Ellis Huber, Mitbegründer des Berliner Gesundheitsladens und späterer Präsident der Dt. Ärztekammer. Mit der Idee des Gesundheitstages, dem noch einige weitere folgen sollten, reagierte Huber auf Impulse zu einer Gegeninitiative kritischer Mediziner_innen und von Patient_innen zu dem vom 14. bis 18. Mai 1980 stattfindenden Deutschen Ärztetag.

Auf dem Gesundheitstag diskutierten mehr als 12000 Teilnehmende Friedens-, Umwelt- und Selbsthilfethemen. Nicht zuletzt spielte die Auseinandersetzung mit der nationalsozialistischen Vergangenheit einer „Medizin ohne Menschlichkeit“ (Mitscherlich) eine wichtige Rolle für die Entwicklung eines neuen Selbstverständnisses von Gesundheit und der Gesundheitsberufe. In diesem Zusammenhang gewann auch die italienische Arbeitermedizin an Bedeutung. In seinem einschlägigen und später oft zitierten Vortrag betonte Helmut Wintersberger auf eben diesem ersten Gesundheitstag in Berlin die Handlungsfähigkeit von Beschäftigten im Betrieb. Für alle unsere Interviewpartner_innen der später gegründeten AG Arbeitermedizin war dies der Beginn ihrer vertieften Auseinandersetzung mit dem betrieblichen Arbeits- und Gesundheitsschutz. Offensichtlich traf Wintersberger mit seiner Erzählung einen Nerv, der in einem Teil der Gesundheitsbewegung für Resonanz sorgte und den Rahmen für die These spannte, dass es legitim sei, sich um die eigene Gesundheit im Betrieb zu kümmern. 
Die Erfahrungen auf dem Berliner Gesundheitstag bestärkten das Engagement zur Gründung eines Hamburger Gesundheitsladens im Jahr 1981. Dessen Räume nutzte neben diversen Initiativen aus der Anti-AKW-, der Öko- oder auch der Antipsychiatriebewegung, auch die AG Arbeitermedizin. Die AG selbst wurde zwar als eigenständig, aber dem Gesundheitsladen und damit den NSB zugehörig wahrgenommen.

Zentral für die Gründung des Vereins Arbeit \& Gesundheit e.V. war jedoch zunächst eine Initiative, die nicht originär im Hamburger Gesundheitsladen entstand: der Leverkusener Entgiftungskongress im Herbst 1985. Die 1980 aus der Umweltbewegung hervorgegangene Partei Die Grünen initiierte diesen zum Thema Chlorchemie; maßgeblich durchgeführt von deren Hamburger Fraktion. Eine AG sollte sich mit dem Thema Gesundheitsschutz am Arbeitsplatz befassen; vorbereitet und koordiniert von einem späteren Gründungsmitglied des Vereins, der sich zu jener Zeit und lokal bekannt intensiv mit dieser Problematik befasste. In der AG trafen sich viele Hamburger_innen, die beschlossen, diesen Austausch in ihrer Stadt fortzusetzen.

Das erste Treffen der sich Arbeit \& Gesundheit nennenden Gruppe fand Anfang 1986 im Hamburger Gesundheitsladen statt. Einige kannten sich aus der AG Arbeitermedizin. Der Informationsaustausch verstetigte sich in einem monatlichen Plenum. Die Gründungsmitglieder kamen aus ganz unterschiedlichen Kontexten: den Naturwissenschaften, der Arbeitsmedizin, der BR-Arbeit etc. Ihr vorheriges Engagement speiste sich aus der AntiAKW-Bewegung, der Gesundheitsladenbewegung, der Umweltbewegung. Das spiegelte sich in den Wissensbeständen, die einzelne Mitglieder nutzten, um strategisch das Thema Gefahrstoffe in gewerkschaftliche Diskussionen einzubringen.

Das Thema Gefahrenstoffe, verbunden mit persönlichen Beziehungen, war ein Treiber unter anderen, der von der Umweltproblematik auch zur Umwelt des Betriebes und dessen Innenleben führte. Persönliche Kontakte nach England ermöglichten einem der Gründungsmitglieder, die Hazards Groups (zur historischen Genese: Brendstrup, 2016) kennenzulernen. Diese berieten in enger Kooperation mit, jedoch institutionell unabhängig von Gewerkschaften zu Fragen des Arbeitsschutzes. Auch die Science Shops, in denen Wissenschaftler_innen und Gewerkschafter_innen zusammenarbeiteten, motivierten zur Vereinsgründung. Das Vorbild waren also bereits Knowledge Broker-Gruppen, die als Intermediäre Fachwissen übersetzten.

Die Gruppe Arbeit \& Gesundheit wollte einen Verein gründen, der zunächst an den Gesundheitsladen angebunden werden sollte. Die Idee wurde verworfen: Für viele im Gesundheitsladen war ein betrieblicher Arbeits- und Gesundheitsschutz nicht das Thema. Dementsprechend hätte Überzeugungsarbeit geleistet werden müssen, die jedoch niemand leisten wollte (Gründungsmitglied, persönliche Kommunikation, 22. Juli 2017). Auch die Themenfülle im Gesundheitsladen wurde als Hindernis gesehen, das Beweglichkeit einschränkte. So entschieden die Akteur_innen pragmatisch, mit der Vereinsgründung einen eigenen Weg zu gehen. Die Argumente der AG Arbeitermedizin mobilisierten demnach nicht in großem Ausmaß; eine Mobilisierungsfähigkeit bereits etablierter Organisationen wie Gewerkschaften ergab sich hier über eine Institutionalisierung als Verein jenseits der Bewegungen. Deutlich wird, dass für die Bewegungsforschung die Frage nach Verstetigung - nicht nur aus strategischer, sondern auch aus pragmatischer Sicht - für die Mobilisierungsfähigkeit (Frame-Resonanzen) und als Teil von Framing-Prozessen fruchtbar sein kann. 
Der Verein sollte eine Beratungsstelle tragen. Die Konzeptentwicklung und der Aufbau der Beratungsstelle warfen Finanzierungsfragen auf. Eine Idee sah vor, die Beratungsstelle über die geplanten Zentren der Humanisierung der Arbeit laufen zu lassen. Die Kooperationsstelle Hochschulen/Gewerkschaften, die Betriebsräte und Gewerkschaftssekretäre mit der Wissenschaft vernetzen sollte, unterstützte dies, u.a. deshalb, weil sie selbst aufgrund fehlender Kapazitäten nicht allen Anfragen und Bitten um Beratung nachkommen konnte. Neben Bund und Land baten die Vereinsaktiven die Gewerkschaften um Unterstützung. Ein Gründungsmitglied vermutet, dass die Gespräche wegen einer grundsätzlichen Abwehrhaltung gegenüber denen ,,von außen“ scheiterten: „Für die waren wir Exoten. Wir kamen nicht aus deren Stall. (...) Wir waren unter Rot-Grün-Verdacht, Rot im Sinne von KGruppen und Maoisten“ (Berater, persönliche Kommunikation, 22. Juli 2017). Dass dies gerade auf das interviewte Gründungsmitglied nicht zutraf, erscheint an dieser Stelle besonders bemerkenswert und als eine Art Ironie der Geschichte.

Aus Sicht eines damaligen DGB-Referatsleiters (persönliche Kommunikation, 5. Juli 2017) seien Gewerkschaften zu einer dauerhaften Finanzierung nicht in der Lage gewesen. Er nahm eher den Stellenabbau wahr, sowohl in den Mitgliedsgewerkschaften als auch beim DGB selbst. Die „mit großer Verve“ als Kooperationsprojekte ins Leben gerufenen Kooperationsstellen oder auch die Technologieberatungsstellen (TBS), selbst institutionell angelegte Knowledge Brokers (Meyer, 2010, S. 119), verblassten in ihrer Wirkkraft, da diese nicht adäquat ausgebaut worden seien.

Schlussendlich entschieden die Vereinsmitglieder, finanziell unabhängig von Gewerkschaften zu bleiben und ihre Beratungsstelle mit Unterstützung des Stadtstaates Hamburg ins Leben zu rufen. Ab März 1989 wurde die Arbeit der Informationsstelle Arbeit \& Gesundheit ehrenamtlich geleistet. Möglich wurde dies mit einer staatlichen Anschubfinanzierung von 5000 DM. Im Oktober 1990 konnten durch die politische Unterstützung des Hamburger Amtes für Arbeitsschutz ABM-Mittel des Arbeitsamtes und Komplementärmittel der Freien und Hansestadt Hamburg für die ersten drei Jahre gewonnen werden, die eine Hauptamtlichenstruktur ermöglichten. Der Preis für diese Mittel war eine intensive politische Lobbyarbeit, in der die Bedeutung der Arbeit der Beratungsstelle immer wieder auch mit Fachwissen belegt werden musste. Wissenschaftliche Erkenntnisse erzeugten Relevanz und entkräfteten Vorurteile. Sichtbar wird ebenso, dass ein Verständnis politischer Prozesse auf Stadtstaatebene wichtig ist, wenn es um das Organisieren von Unterstützung und die dafür notwendige Vernetzungsarbeit geht.

Während die Gesundheitsbewegung in Hamburg 1995 mit der Auflösung des Gesundheitsladens ihr Ende „feierte“ (Aktiver im Gesundheitsladen, persönliche Kommunikation, 5. Mai 2017), wurde der Verein selbst zu einem entscheidenden Akteur im Vernetzen verschiedener in Hamburg Engagierter im betrieblichen Arbeits- und Gesundheitsschutz. Der Austausch endete nicht an den Stadtgrenzen Hamburgs: Auch deutschlandweit und auf europäischer Ebene gab und gibt es regelmäßige Treffen (Berater, persönliche Kommunikation, 22. Juli 2017).

Welche Aushandlungsprozesse in den unterschiedlichen Phasen der Transformationen erinnert und welche Themen damit verknüpft wurden, wird exemplarisch im nächsten $\mathrm{Ab}$ schnitt skizziert. 


\subsection{Protestkommunikation: Themen, Adressat_innen und Konfliktlinien}

Zunächst lässt sich der Hamburger Gesundheitsladen als räumlicher und kommunikativer Kristallisationspunkt für ein breites Spektrum an Themen beschreiben: von der Antikriegspolitik, der Nazimedizin, dem NATO-Doppelbeschluss bis hin zu alternativer Medizin, gesunder Ernährung, Beratung bei Abtreibung und Selbsthilfe (Aktiver im Gesundheitsladen, persönliche Kommunikation, 5. Mai 2017). Alle Initiativen bewegten sich in ihrer Protestkommunikation zur Gesundheitspolitik zwischen den Polen einer Veränderung der Verhältnisse und auf Verhaltensänderungen zielende Strategien individueller Prävention und selbstverantwortlicher Gesundheitssorge. Daraus entstanden immer wieder konflikthafte Positionierungen, die statt problembezogen die Berechtigung jeder dieser Strategien auszuloten, oft auch moralisierend gegeneinander ausgespielt wurden. Trotz dieser Konflikte und als Weg, sie pragmatisch zu umgehen, kam es dann zu eigenständigen Verstetigungsbemühungen außerhalb des Gesundheitsladens wie es nun am Beispiel der AG Arbeitermedizin illustriert werden wird.

In der AG Arbeitermedizin standen zwei Themen im Vordergrund: erstens das der Umwelt (im Sinne von Umweltbelastungen im Betrieb und der Außenwelt durch industrielle Immissionen). Und zweitens eng damit verknüpft das der Gesundheit, verstanden als gesundheitliche Belastungen in der Lohnarbeit). Beide Themenkomplexe eigneten sich für Anschlusskommunikationen im Feld des Arbeits- und Gesundheitsschutzes, die die AG Arbeitermedizin sowohl im Gesundheitsladen als auch in den Betrieben und an der Universität vollzog. Dabei repräsentiert der Perspektivwechsel von der Arbeitsmedizin hin zur Arbeitermedizin nicht nur eine Subjektivierung (also den Blick auf das körperlich-psychische Belastungserleben der Beschäftigten), sondern auch eine Erweiterung des Adressatenkreises mit der Aussage und der Aufforderung: ,Jeder ist Experte seiner eigenen Gesundheit“ (Vereinsmitglied, persönliche Kommunikation, 11. Juli 2017). Damit grenzte sich die AG von der Schulmedizin und der ihren Paradigmen folgenden Arbeitsmedizin ab.

Die Protestkommunikation der AG fokussierte zunächst auf Gefahrenstoffe. Argumentativ wurde das Thema mit einem als defizitär gesehenen, zunächst stoffbezogenen Arbeitsschutz verbunden. So kamen arbeitsregulatorische Fragen auf die Agenda. Zudem setzte sich die AG mit dem Thema krankheitsbedingte Kündigungen auseinander - nach dem Gesundheitstag bspw. in einer interdisziplinär angelegten Veranstaltungsreihe im Gesundheitsladen, an denen u.a. Juristen beteiligt waren. Handlungsleitend war dabei die Frage, wie die Ergebnisse der Ursachenforschung zu Krankheiten von Arbeiter_innen in rechtlich normierte Gewährleistungsansprüche überführt werden könnten. An dieser Stelle gilt es zu betonen, dass die AG Arbeitermedizin den Frame Gesundheit nicht strategisch erweitern wollte (Frame Extension, Benford \& Snow, 2000, S. 624), um möglicherweise die Gewerkschaften mit an Bord zu holen. Vielmehr ergaben sich aufgrund der Mehrfachmitgliedschaften Diffusionsmöglichkeiten in Gewerkschaften, die jedoch weder als Gegner gesehen noch Teil der NSB waren, sondern als Resonanzboden Aspekte aufnahmen und andere, verbunden mit einer Sachzwanglogik des Arbeitsplatzerhalts, ignorierten.

Im Kontext der Arbeitermedizin zog sich ein erster betrieblicher Aktionsradius um die Hamburger Aluminiumwerke, auch bedingt durch ein BR-Mitglied, das selbst in der AG aktiv war. Die Aluminiumhütten emittierten Fluor in einem Ausmaß, das die Umgebung des Werkes schwer schädigte, wie z.B. die Blumen- und Obstplantagen. Auseinanderset- 
zungen zwischen den Ansprüchen der Obstbauern und dem Management der Aluminiumwerke um die industriellen Arbeitsplätze folgten. Das Management regte eine Demonstration für den Erhalt der Arbeitsplätze an - unter dem Motto: „1000 Arbeitsplätze sind wichtiger als 10000 Gladiolen“ (BR-Mitglied, persönliche Kommunikation, 6. Juli 2017). Es suchte sich strategische Partner, auch im BR. Bei den folgenden BR-Wahlen war die Position des Arbeitgebers jedoch nicht mehrheitsfähig. Diejenigen im BR, die auch die Anliegen der Anwohner_innen befürworteten, setzten sich durch. Dieser Konflikt zeigte exemplarisch, dass der Erhalt des Arbeitsplatzes nichts mehr problemlos gegen den Erhalt der Gesundheit und der Umwelt ausgespielt werden konnte.

Das Prinzip ,,non delegata“ der italienischen Arbeitermedizin diffundierte in eine der ersten Aktionen des neu gewählten BRs in den Hamburger Aluminiumwerken. Er organisierte eine innerbetriebliche Befragung von Beschäftigten $\mathrm{zu}$ den gesundheitlichen Beschwerden. Den Fragebogen entwickelten Betriebsaktive und Mediziner_innen aus der AG Arbeitermedizin gemeinsam abends in ihren privaten Räumen. Er enthielt wesentliche Punkte, die man in heutigen Gefährdungsbeurteilungen wiederfindet, einschließlich vieler Merkmale für psychische Belastungen. ${ }^{9}$ Bereits hier deutet sich an, dass der Anspruch, selbst zum_r Expert_in der eigenen Gesundheit im Betrieb zu werden, in arbeitsregulatorische Prozesse eingreift. Gerade deshalb reagierte das Management prompt mit einer Unterlassungsklage vor Gericht, um die Verteilung des Fragebogens zu unterbinden. „Dann sind wir, also der BR, subversiv geworden“ (Vereinsmitglied, persönliche Kommunikation, 11. Juli 2017). Drei Tage vor der Gerichtsverhandlung nutzte der BR diese Zeit, um möglichst viele Kollegen zu befragen. So hätte man Informationen gehabt, falls das Gericht die Fragebogenaktion untersagen würde. 300 von 800 Beschäftigten füllten den Fragebogen aus. Das Gericht ließ letztlich die Beschäftigtenbefragung durch den BR zu. Daraufhin kamen noch ca. 100 weitere beantwortete Fragebögen hinzu. ${ }^{10}$ Die Daten wurden zu ,eine(r) rationale(n) Grundlage für eine kontinuierliche Diskussion um Gesundheitsfragen am Arbeitsplatz“. Arbeitsbedingte Kündigungen waren in den nächsten Jahren zudem selten: „Das werteten wir damals als kleinen Erfolg“ (Vereinsmitglied, persönliche Kommunikation, 11. Juli 2017).

Diese Aktion zeigt, dass sich bereits hier die Protestkommunikation der AG Arbeitermedizin gegen Fluoremission zu einem Kommunikationshandeln erweiterte, dass das Gefüge im Betrieb veränderte und damit die Regulierung der Arbeitsbedingungen spezifisch beeinflusste. Während die Protestkommunikation diverse Aktive im Gesundheitsladen u. a. darüber miteinander verband, dass andere die Verantwortung tragen und den Missstand zu beseitigen haben, begab sich die Gruppe der Arbeitermedizin mit der Fragebogenaktion in eine andere Rolle. Denn die in der AG aktiven BR-Mitglieder wollten konkrete Veränderungen im Betrieb umsetzen, sahen sich selbst dazu in der Lage und letztlich auch in der Verantwortung (BR-Mitglied, persönliche Kommunikation, 6. Juli 2017) - und zwar auf-

9 Bereits 1977 kooperierten Beschäftigte einer norddeutschen Werft mit Wissenschaftlern der Universität Bremen und des Wissenschaftszentrums Berlin zum Thema Arbeitssicherheit und Belastungen. Hier wurden ebenfalls unter Bezug auf die italienische Arbeitermedizin Daten durch Fragebögen erhoben und strategisch in Verhandlungen mit dem Management eingesetzt (Brock, Funke, Einemann, Abholz \& Hoppensack, 1980, S. 49-75).

10 Beschäftigte mit türkischer Migrationsgeschichte konnten den Fragebogen nicht ausfüllen, da dieser nicht übersetzt war. 
grund ihres qua Recht verliehenen Status' und der damit verbundenen Gestaltungsmacht. Das Besondere scheint hier also zu sein, dass BR-Mitglieder und Arbeitsschützer_innen als Akteur_innen in den NSB ihre Kommunikationsbeziehungen nutzten, um in den sozialen Auseinandersetzungen im Betrieb neue „Sets von Regeln und Ressourcen“ zu schaffen und damit auch unterschiedliche soziale Ebenen miteinander verknüpfen.

Neben rechtlich legitimierter Verhandlungsmacht benötigten die Themen des Arbeitsund Gesundheitsschutzes Fachexpertise - sowohl im medizinischen als auch im rechtlichen Bereich. Über eine informelle Vernetzung auf lokaler Ebene konnte Fachwissen beschafft und erworben werden. So stellte der Leiter der Kooperationsstelle Hochschule/Gewerkschaften einen Kontakt zwischen einem BR-Mitglied der Aluminiumwerke und einem Professor her, der ein portables Massenspektrometer entwickelt hatte. Die im Warmwalzprozess freigesetzten Stoffe konnten gemessen und Indikatoren für hochtoxische Stoffe bestimmt werden. Daraufhin war der BR in der Lage, gezielt ein zugelassenes Messinstitut in den Betrieb zu holen und Einfluss auf die Zusammensetzung der Kühlschmierstoffe zu nehmen.

Dieser Erfolg auf betrieblicher Ebene war begleitet von Konflikten zwischen einem Teil der hauptamtlichen Gewerkschafter_innen und BR-Mitgliedern, die gleichzeitig in NSB und in Gewerkschaften aktiv waren. Die Linien der Auseinandersetzung lassen sich mit der Frage nach den Adressaten des Protests und mit der Frage nach dem Publikum entlang unterschiedlicher Betroffenheitslagen nachzeichnen. Adressat des vom BR initiierten Protests waren neben dem Arbeitgeber auch die Hersteller der Kühlschmierstoffe, BGen und letztlich die Gewerkschaften - die IG Chemie (später BCE) und die IG Metall. Die gesetzlich für Arbeitsgefährdungen zuständigen und von Arbeitgebern finanzierten BGen wurden von den Gewerkschaften als Regulierungsort für den Arbeitsschutz angesehen. Die in der AG Arbeitermedizin Aktiven waren gleichwohl nicht davon überzeugt, dass die BGen das gesamte Spektrum des entsprechenden arbeitsmedizinischen Wissens einschließlich vom Mainstream abweichender kritischer Positionen auch tatsächlich kannten oder nutzten (BRMitglied, persönliche Kommunikation, 6. Juli 2017). Während also Gewerkschaften an dem Selbstverwaltungsprinzip als Teil der tradierten Arbeitsregulation festhielten und seiner Funktionsweise vertrauten, setzte die AG neue Impulse betrieblicher Partizipation.

In der Auseinandersetzung um angemessene Regulierungsformen im Bereich des Arbeits- und Gesundheitsschutzes zeigte sich ein für das Verhältnis zwischen NSB und Gewerkschaften bedeutsamer Dissens: Die Gewerkschaften in den 1970er-Jahren und damit in Zeiten der Deindustrialisierung sahen den Arbeitsplatzerhalt und Tariferhöhungen als Hauptziel in den Verhandlungen und legitimierten dieses mit dem Argument der Standortsicherung. Die im Gesundheitsladen engagierten BR-Mitglieder wählten einen anderen Kurs. Sie stellten, inspiriert von den Erfahrungen auf den Gesundheitstagen, Forderungen nach Mündigkeit, Selbstbestimmung und Partizipation in den Mittelpunkt. Die Beschäftigten sollten über ihr Leben auf der Arbeit verfügen können; das sollte ein um den Gesundheitsschutz erweitertes Verständnis des Arbeitsschutzes leisten. Diese Positionen diffundierten über Mehrfachmitgliedschaften in formalisierte Netzwerkstrukturen der Gewerkschaften, in politischen Ausschüsse, in die Institutionen der BGen. Ein Generationenwechsel der Hauptamtlichen begünstigte, dass Arbeitssicherheit zunehmend als Arbeits- und Gesundheitsschutz verstanden wurde. 
Zusammenfassend lässt sich festhalten, dass Gewerkschaften Themen sozialer Bewegungen dann aufnehmen können, wenn Plausibilitätszonen geschaffen werden, die für die Organisation Gestaltungsoptionen eröffnen. Inwiefern Gewerkschaften selbst Themen von NSB aufgreifen, hängt auch von ihrem wahrgenommenen Bedarf an Ressourcen (Fachwissen, Mitgliederstabilisierung oder -neugewinnung) und dem Ausmaß des öffentlichen Drucks ab. Damit sind Gewerkschaften nicht nur Adressat und Akteur, sondern auch Publikum, das es zu überzeugen gilt oder in dessen Namen die in der Bewegung Aktiven konsensuell zu sprechen gedenken.

Das Agieren in den Plausibilitätszonen wiederum schafft Koalitionsmöglichkeiten im betrieblichen Arbeits- und Gesundheitsschutz. Am Beispiel der Arbeitermedizin zeigt sich, dass sowohl Kommunikationswege zwischen hauptamtlichen Gewerkschafter_innen und Beschäftigten als auch neue und auf die gesamte Bevölkerung bezogene Themen seitens der Gesundheitsbewegung neue Plausibilitätszonen aufspannten, die in Teilen in gewerkschaftliche Programmatiken diffundierten. So griffen in den 1990er-Jahren Gewerkschaften wie die IG BCE den Slogan „Experten in eigener Sache“ auf, der semantisch an die Beschäftigtenumfragen anschloss (Deiß \& Heidling, 2001, S. 73). Auch die Befragungen der IG Metall oder der DGB-Index Gute Arbeit basieren auf dem Instrument der Beschäftigtenumfragen. Die Plausibilitätszone, die durch den verhandelten Erfolg wahrnehmbar wurde, eröffnete Gewerkschaften die Option, in Fragen der Arbeitsregulation durch Vernetzung neue Ressourcen wie Fachwissen zu mobilisieren und bisherige Grenzen des Arbeits- und Gesundheitsschutzes zu hinterfragen, öffentlich dagegen zu protestieren und neu zu verhandeln. So konnte es Arbeit \& Gesundheit gelingen, dass sich auch die Gewerkschaften für die Erweiterung des Arbeitsschutzes zum Arbeits- und Gesundheitsschutz stark machten.

Die Gesundheitsladenbewegung selbst nahm arbeitsregulatorische Fragen des betrieblichen Arbeits- und Gesundheitsschutzes aufgrund ihrer zentralen Sinn stiftenden Themen wie „Enteignung der Gesundheit“ (Illich, 1975) durch das dominante medizinische Krankheitsmodell nur sehr begrenzt auf. Während ein Teil der Bewegung an einer radikalen Veränderung der kapitalistischen Verhältnisse festhielt, konzentrierte sich der größere Teil auf einen Bewusstseinswandel in Richtung einer individuellen Wiederaneignung der eigenen Gesundheit und einer ganzheitlichen Wahrnehmung von Gesundheitsproblemen, teilweise schon im Kontext von Umweltschäden. Arbeitsbedingungen als ein Moment der Arbeitsregulation sind hingegen auf einer Mesoebene angelegt und bedürfen konkreter Handlungen, die die Veränderung betrieblicher Verhältnisse in den Blick nehmen.

Die spezifische Zusammensetzung der AG Arbeitermedizin aus Akteur_innen, die auf den Handlungsort Betrieb schauten, und deren Orientierung auf betriebliche Verhältnisse boten die Voraussetzung, ihr Engagement zu verstetigen, in dem sie Arbeit \& Gesundheit gründeten. Die Vereinsmitglieder waren in der Anerkennung ihrer Kompetenzen auf ein voraussetzungsvolles Wissen der (Natur-)Wissenschaften angewiesen, um von anderen Funktionsbereichen wie der Wirtschaft und dem Staat, aber auch von Organisationen wie den Gewerkschaften gesehen, wahrgenommen und akzeptiert zu werden.

Dass die Aussagen der AG Arbeitermedizin plausibel wurden, verdankte sich auch dem Schritt, über die Vereinsgründung zu einem Akteur zu werden, der rechtssicher war. Welche Rolle rechtliches und fachwissenschaftliches Wissen im Kommunikationshandeln der 
AG Arbeitermedizin innerhalb des Gesundheitsladens und des späteren Vereins Arbeit \& Gesundheit zum Arbeits- und Gesundheitsschutz spielten, wird nun ausführlich analysiert.

\subsection{Regulation im Arbeits- und Gesundheitsschutz: Verrechtlichungs- und Verwissenschaftlichungsprozesse}

Grundsätzlich charakterisiert die Regulierung des Arbeits- und Gesundheitsschutzes ein arbeitsmedizinisches und ein rechtliches Fachwissen. Durch die Zusammenarbeit in der AG Arbeitermedizin verschafften die angehenden Arbeitsmediziner_innen mit ihrer Expertise den BR-Mitgliedern in den Verhandlungsprozessen um gesündere Arbeitsbedingungen eine deutlich bessere Ausgangsposition. Andererseits ermöglichte das präsentierte Fachwissen dem BR Anerkennung, legitimierte seine Forderungen und wurde zum Hebel, Diskussionen zu eröffnen und das Recht zu einem „law in action“ werden zu lassen. Über die Dichte des Netzwerkes und die Erreichbarkeit der vernetzten Personen mit ganz unterschiedlichen Expertisen gelang es dem BR, die „Linien und Fronten der Ausgestaltung von Arbeitsregulation" (Windeler \& Wirth, 2010, S. 584) zugunsten der Erweiterung des Arbeits- und Gesundheitsschutzes zu verschieben und jenseits des etablierten Regelungsinstrumentes ,Tarifvertrag' $\mathrm{zu}$ formalisieren, indem eine innerbetriebliche anerkannte Regelung oder Handlungsoption erarbeitet wurde. Die Bewegung setzte den Impuls. Vernetzung war die Praxis, die zu einem neuen Modus der Interessenregulierung wurde, wie es Windeler und Wirth (2010, S. 589) später als normatives Prinzip fordern. ${ }^{11}$

Als der Verein die Grundlage für eine Beratungsstelle zu Berufskrankheiten und Arbeitsunfällen geschaffen hatte, waren die nun angestellten Akteur_innen in der Lage, sich weiteres Fachwissen anzueignen und über die staatliche Finanzierung legitimiert als Expert_innen gegenüber Gewerkschaften, betrieblichen Akteur_innen, aber auch gegenüber den BGen aufzutreten. So konnten sie einen Einblick in Dokumente und Entscheidungsprozesse anderer Institutionen in der Regulation um betrieblichen Arbeits- und Gesundheitsschutz gewinnen. Die Glaubwürdigkeit einzelner Gründungsmitglieder, ihr wissenschaftlicher Status qua Titel und ihr damit verbundenes Fachwissen, stieß nicht im Gesundheitsladen und damit der Bewegung auf Resonanz, sondern in den Institutionen im Prozess der Verstetigung. Diese Resonanz erhöhte die Chance, rechtlich legitimiert Anträge z.B. auf Fördermittel bewilligt zu bekommen.

Ein Teil der Gruppe Arbeitermedizin durchlief damit selbst eine Institutionalisierung, die ihr Stabilität bzw. zunächst einmal Handlungsoptionen eröffnen sollte. „Als lockeres Plenum hätte das nicht funktioniert“" (Vorstand, persönliche Kommunikation, 6. Juli 2017). Der Vereinsstatus gestattete, als juristisch anerkannte Person Gelder für eine Beratungsstelle, für Forschungsprojekte etc. zu akquirieren. Damit ließ sich erstens als quasi intermediäre Instanz eine Korrekturfunktion hinsichtlich möglicher Fehlentscheidungen von BGen ausüben. Zweitens wurde Beratung weniger zufällig: Es bildeten sich in dem kleinen Kosmos Beratungsstelle Beratungsmuster heraus, die eher eine Gleichbehandlung, Partizipation und Transparenz ermöglichen. Drittens konnte das erworbene Fachwissen der sozial Be-

11 Ende der 1990er-Jahre wurde die Rolle von Expert_innen und Berater_innen für die BR-Arbeit als Frage nach ,innovativen Formen der Mobilisierung von Expertenwissen“ (Deiß \& Heidling, 2001, S. 7) für eine „Mitbestimmung im Wandel“ formuliert. 
wegten professionell durch die öffentliche Förderung legitimiert weitergegeben werden. Diese Anerkennung hatte für die Betroffenen mitunter eine günstigere Verhandlungsposition zur Folge. Viertens führten das Fachwissen und die öffentliche Förderung zur Nominierung von Vereinsmitgliedern in politische Gremien, zu Fördergeldern für Forschungsprojekte und zu verantwortungsvollen Positionen in öffentlichen Projekten. So wurde die Beratungsstelle zu einer anerkannten Quelle für einschlägige Expertisen, deren Beschäftigte die Stadt Hamburg als Ansprechpartner benannte. Die Anerkennung der Expertise führte dazu, dass öffentliche Geldgeber Kooperationen und Vernetzungen auch aktiv einforderten (Berater, persönliche Kommunikation, 17. März 2017). Gleichwohl stehen bspw. divergierende Interessen einiger Partner_innen der Forderung nach Kooperation entgegen (am Bsp. der psychosozialen Versorgung: Kardorff, 2009, S. 215-217).

Die rechtliche Anerkennung des Vereins und die öffentliche Förderung der Beratungsstelle durch den Hamburger Senat war ebenfalls eine Vorbedingung, um als Akteur in den arbeitsregulativen Beziehungen von den Gewerkschaften ernst genommen zu werden. Die finanzielle Förderung repräsentierte Stabilität, weckte andererseits, so einer der Mitbegründer des Vereins, die Begehrlichkeit, die Fachkompetenz der Beratungsstelle für die eigene Organisation ohne Zusatzkosten zu nutzen (Berater, persönliche Kommunikation, 22. Mai 2017). Er folgte der Einladung in den DGB-Arbeitskreis Gefahrstoffe als Experte und nahm das als eine Art Bewährungsprobe wahr. Im Anschluss daran durchlief er mehrere Stufen als Vertreter mit zunehmender Verantwortung (Projektgruppe, Haupt- und Unterausschüsse, europäische Ebene). Dies war nur aufgrund der Etablierung eines Vertrauensverhältnisses möglich. Dass fachliche Vorschläge politisch aufgegriffen wurden, war für ihn einerseits zufallsabhängig: Wer war noch im Ausschuss, wer hauptamtlich, wer verfügte über welche Netzwerke und welches Fachwissen? Andererseits konnte ein Unterfüttern mit Fachkompetenz statt ideologischer Positionierung aus seiner Sicht ebenfalls mehr Gehör erwirken. Damit nahm er explizit eine Knowledge Broker-Position ein, die es erforderte, verschiedene Perspektiven miteinander ins Gespräch zu bringen, eben weil er auch die Fachsprache beherrschte. Wissen zu vermitteln bzw. zu transformieren kann jedoch nur dann gelingen, wenn dieses Angebot der Knowledge Broker auch genutzt wird. Eine ehemalige Betriebs- und Gewerbeärztin (Vereinsmitglied, persönliche Kommunikation, 11. Juli 2017), bot bspw. mit einem Amt in einem Gremium versehenen BR-Mitglieder an, ihnen wichtige arbeitsmedizinische Aspekte für die Gremienarbeit zu vermitteln; diese nutzten das Angebot jedoch nicht.

Fachliche Vorschläge des Beraters mit einer naturwissenschaftlichen Ausbildung (persönliche Kommunikation, 25. Dezember 2017) hatten allerdings durchaus Erfolg: Bspw. wirkte er maßgeblich an der Technischen Regel für Gefahrstoffe (TRGS) 910 mit: das „Risikobezogene Maßnahmenkonzept für Tätigkeiten mit krebserzeugenden Gefahrstoffen“. Im Unterausschuss des Ausschusses für Gefahrstoffe (AGS) wurde über die Regelung von Expositionsgrenzen für krebserzeugende Stoffe am Arbeitsplatz diskutiert. Er kritisierte als nominierter Vertreter der Gewerkschaften, dass in der Regulierung von krebserzeugenden Stoffen am Arbeitsplatz technikbasierte Grenzwerte (Technische Richtkonzentration = TRK) die Basis zur Beurteilung darstellten. Die resultierenden TRK-Werte waren für die betreffenden Stoffe mit quantitativ ganz unterschiedlichen Krebsrisiken (genauer: Eintrittswahrscheinlichkeiten für das Entstehen einer Krebserkrankung) verknüpft, was für die 
resultierenden regulatorischen Folgen jedoch unerheblich war. Die Folgen bestimmten sich nur danach, ob der TRK-Wert eingehalten wurde oder nicht. Anders formuliert lassen sich am TRK-Wert die von Stoff zu Stoff ganz unterschiedlichen Erkrankungswahrscheinlichkeiten nicht ablesen.

Es gelang ihm, ab 1999 - zunächst im entsprechenden DGB-Facharbeitskreis und dann im Unterausschuss - diese Kritik systematisch und konkrete Änderungsvorschläge zu formulieren. Den rechtlichen Regulierungsrahmen steckte die Gefahrstoffverordnung (GefStoffV) ab, die im Zuge einer 1998 verabschiedeten EU-Richtlinie zur Gefährdungsbeurteilung zu überarbeiten war. Die TRK-Werte wiederum ließen eine konsistente Gefährdungsbeurteilung nicht zu, da sie unterschiedliche Risikohöhen aufwiesen; d.h. das Risiko, aufgrund der Tatsache, einem Gefahrstoff ausgesetzt gewesen zu sein, an Krebs zu erkranken, stellte selbst eben nicht die zentrale Bemessungsgrundlage dar.

Nachdem die Fachabteilung des damaligen Bundesministeriums für Wirtschaft und Arbeit mit ihrem Vorschlag, risikobasierte Grenzwerte als Ersatz für die bisherigen TRKWerte zu nutzen, auf heftigen Widerstand der Wirtschaft stieß, und sich der Dissens nicht auflösen ließ, wurden in der novellierten GefStoffV Ende 2004 zwar die TRK-Werte abgeschafft. Nachfolge-Größen gab es jedoch noch keine. Vielmehr wurde der AGS mit der Aufgabe betraut, ein Nachfolge-Konzept (möglichst in Form eines risikobezogenen Konzepts) zu erarbeiten. Aufgrund der ab 2001 bestehenden Mitgliedschaft im AGS gelang es dem Interviewten für die Gewerkschaften diesen Auftrag mitzugestalten und zentrale Impulse zu setzen. Fachpolitisch war dies auf Gewerkschaftsebene möglich, da er die grundsätzliche Diskussion im DGB-Facharbeitskreis seit 1999 angeschoben und intensiv geführt hatte.

Gleichzeitig verdeutlicht das Thema Gefahrstoffe, dass dieses spezifische Wissen immer auch kontrovers im Wechselverhältnis zwischen Expertisen und Gegenexpertisen und als „Politikum“ mit „bewussten Prozessen der Wissensunterdrückung“ (Böschen, 2000, S. 193) gehandhabt wird. Dabei spielen Fragen der Anerkennung von Gefährdungen eine große Rolle (zur Risikogenese am Bsp. v. Dioxin: Böschen, 2000, Kap. 5).

Insgesamt lassen sich die Bewegungen jener Zeit als ambivalente Erfolgsgeschichte lesen. Während einerseits eine institutionelle Stabilisierung Verlässlichkeit schuf, wurde das Engagement verwaltbar, transparenter und damit kontrollierbar. Für die Behörden hatte die Finanzierung der Beratungsstelle auch eine Entlastungsfunktion. Die Unzufriedenheit konnte an bereits mit viel ehrenamtlichem Engagement etablierte und nun städtisch finanzierte Beratungsangebote weitergegeben werden.

Das Format der Förderung von Projekten mit begrenzter Dauer bedeutete jahrzehntelang eine Selbstausbeutung der von Anbeginn Engagierten, die heute zum Hindernis der Verstetigung zu werden droht, da sich Prioritäten im Lebensentwurf verändern. Und dennoch ist zumindest derzeit das Engagement der Nachwuchsgeneration im Verein sehr hoch: hier vor allem im Bereich von Professionalisierung und der Aneignung von Spezialwissen als Voraussetzung zielgerichteter und akzeptierter Interessendurchsetzung. Vorher in der AG Arbeitermedizin Engagierte haben mit ihrer eigenen Professionalisierung andere Orte des Engagements wie das Gewerbeamt oder die Betriebsmedizin gefunden. Die Distanz zur Bewegung, aber auch zur Institution Arbeit \& Gesundheit e.V. nahm bei einigen zu (Vereinsmitglied, persönliche Kommunikation, 11. Juli 2017). Für diese Aktiven bedeutete das 
auch das Ende ihrer Bewegungszeit und in letzter Konsequenz auch das Ende der Bewegung.

Nicht zuletzt waren es auch Zufälle, die einige Interviewte mit Blick auf Entstehung und Bestehen von Arbeit \& Gesundheit e.V. ins Gespräch brachten. Das Bestehen des Vereins, trotz Institutionalisierung und Status einer anerkannten Rechtsperson, war etwa vom Wohlwollen der fördernden Instanz abhängig - dies betraf das Ausmaß, in dem Vernetzung mit den jeweils neuen Positionsinhaber_innen und ihren unterschiedlichen Einstellungen und Prioritäten gestaltet werden konnte -, von der Themenkonjunktur bestimmt - d.h. durch das Fenster, das die Politik aber auch die Öffentlichkeit für solche Themen öffnet. Von derartigen, oft zufälligen Konstellationen sind soziale Bewegungen in weitaus größerem Maße abhängig als gewachsene Organisationen.

\section{Fazit}

Am Beispiel der Erfahrungen der Vereinsmitglieder von Arbeit \& Gesundheit e.V. zeigen sich folgende Erfolgskomponenten, die für neue Allianzen für Gute Arbeit von gesundheitlich beeinträchtigten Arbeitnehmer_innen bedeutsam werden können: Das Feld der Arbeitsregulation ist abhängig von den Aktivitäten, Politiken und Kontextbedingungen, in denen die Akteur_innen handeln (Windeler \& Wirth, 2010, S. 584). Das gilt unisono für den Teilbereich des Arbeits- und Gesundheitsschutzes. Die Kontextbedingungen sind derzeit, insbesondere was das Thema der psychischen Gefährdungen angeht, insofern Erfolg versprechend, als sowohl Politik als auch die Sozialpartner mit Blick auf den demografischen Wandel und Fachkräftemangel Belastungen und ihre gesundheitlichen Folgen aufgreifen und das Thema der nachhaltigen Beschäftigungssicherung für ältere und/oder gesundheitlich beeinträchtigte Beschäftigte auf die Agenda setzen. Indikator dafür sind die zahlreichen Initiativen und Vernetzungen über das Bundesministerium für Arbeit (z. B. die Initiative Neue Qualität der Arbeit).

Auf lokaler Ebene belegt dies die Erweiterung des Beratungsangebotes bei Arbeit \& Gesundheit um die Perspektive Arbeit und Gesundheit, die insb. psychische Belastungen fokussiert. Die nicht auf Dauer gestellten Beratungsstellen oder engagierte Betriebsgruppen weisen häufig eine größere Nähe zu den individuell beeinträchtigten Beschäftigten auf. Das allein reicht jedoch nicht. Es bedarf auch eines Fachwissens - sowohl im rechtlichen als auch im arbeitswissenschaftlichen bzw. -medizinischen Bereich. Die Beratungsstellen mit ihrem Trägerverein haben mit der Position einer juristischen Person eine höhere Chance, gesehen und akzeptiert zu werden. Sie können so ihre Protestkommunikation zu einer auf Dauer angelegten Konfliktkommunikation transformieren. Dabei helfen Netzwerke auf nationaler und europäischer Ebene, die Kontakte und eine Vielfalt an Informationsquellen bereitstellen.

Etablierte Akteure wie die Gewerkschaften müssen die Protest- oder aber Konfliktkommunikation von Bewegungen oder aber Beratungsstellen in ihrer Eigenständigkeit anerkennen, ihre Zielsetzungen als legitim betrachten sowie sich offenen Aushandlungsprozessen stellen. Sich allein über den Arbeitsplatzerhalt als politische Forderung zu positionieren, ist weder innovativ noch ermöglicht es eine umfassende präventive Arbeitsregulation. Dazu kann der Arbeits- und Gesundheitsschutz einen wichtigen Beitrag leisten. 
Der heutige Stand des Rechts (z. B. die Lärm- und Vibrationsverordnung) und aktuelle, gesicherte arbeitswissenschaftliche und -medizinische Erkenntnisse bspw. der Bundesanstalt für Arbeitsschutz und Arbeitsmedizin oder der DGUV gewähren eine umfassendere Arbeitsregulation. Erste Anzeichen sind bspw. im Tarifvertrag der Gewerkschaft Erziehung und Wissenschaft 2009, der eine tarifvertragliche Vereinbarung zum Gesundheitsschutz für die Beschäftigten in der Sozial- und Erziehungsarbeit enthält, sichtbar.

Das Fachwissen der Beratungsstellen wiederum ist ein Wissen, von dem die Gewerkschaften in den paritätisch zu besetzenden Gremien auf nationaler und internationaler Ebene profitieren. Hier ließ sich zeigen, dass die Entwicklung, Bereitstellung und Mobilisierung der Fachexpertise für die AG Arbeitermedizin im Gesundheitsladen die Anerkennung als ernstzunehmender Akteur im Feld bedeutete. Für die Gewerkschaften bedeutete der Rückgriff auf diese Fachexpertisen die Legitimation zur Implementierung neuer rechtlicher Regulierungen.

Dennoch bleibt zu betonen, dass Regelwerke allein nur einen Rahmen bilden. Die Plausibilitätszonen schufen letztlich Gelegenheiten, die sowohl NSB-Akteur_innen als auch Gewerkschaften wechselseitig nutzten. Dass sich der Protest für die Gesundheit in eine auf Dauer angelegte Kommunikation im Arbeits- und Gesundheitsschutz wandelte, bedingte einerseits ein lokales Handeln von informierten Akteur_innen, die selbst Verantwortung übernahmen: Als Broker spielten sie auf unterschiedlichen Klaviaturen, kannten die Differenzen in den Wissensbeständen und leisteten die notwendige Transformation, um zwischen den Institutionen zu vermitteln. Die Verstetigung qua Institutionalisierung als Verein war andererseits der materielle Hebel, der Veränderung bewirkte: Die Ansprüche eines Teils der Gesundheits(laden)Bewegung blieben nicht bloßer Protest - an andere gerichtet und diese zum Handeln auffordernd. Im Gegenteil: Die Beratungsstelle Arbeit \& Gesundheit e.V. hat sowohl im Institutionengefüge bewegt und verschoben als auch, und das war schließlich der Anlass der Gründung, Verantwortung dafür übernommen, dass Menschen, die aufgrund ihres Betriebsalltags erkranken, auf ihrem „Marsch durch die Institutionen“ Unterstützung erfahren.

\section{Literatur}

Altenmüller, I. (2015). 18. Juni 1984: Dioxinskandal schockt Hamburg. Abgerufen von http://www.ndr.de/kultur/geschichte/chronologie/18-Juni-1984-Dioxin-Skandal-schocktHamburg/dioxinskandal128.html

Benford, R. D. \& Snow, D. A. (2000). Framing Processes and Social Movements: An Overview and Assessment. Annual Review of Sociology, 26, 611-639. doi: 10.1146/annurev.soc.26.1.611

Bertazzi, P. A., Bernucci, I., Brambilla, G., Consonni, D. \& Pesatori, A. C. (1998). The Seveso studies on early and long-term effects of dioxin exposure: a review. Environmental Health Perspectives, 106 (2), 625-633. doi: 10.1289/ehp.98106625

Böschen, S. (2000). Risikogenese. Prozesse gesellschaftlicher Gefahrenwahrnehmung: FCKW, DDT, Dioxin und Ökologische Chemie. Opladen: Leske + Budrich. doi: 10.1007/978-3-663-11308-9

Brendstrup, T. (2016). (Incomplete) History of EWHN. Abgerufen von http://www.ewhn.eu/ewhnpress/wp-content/uploads/2016/01/History-of-EWHN_2016.pdf

Brock, A., Funke, H., Einemann, E., Abholz, H. H. \& Hoppensack, E. (1980). Betriebliche Gesundheit und gewerkschaftliche Arbeit in einer norddeutschen Werft - Ansätze einer Arbeitermedizin in der BRD. Das Argument Sonderband, 53, 49-75.

Burt, R. S. (2004). Structural Holes: The Social Structure of Competition. Cambridge: Harvard. University Press. 
Czock, H., Göbel, E. \& Guthke, B. (1990). Lesebuch zu Arbeit und Gesundheit - „Man darf nicht wehleidig sein“. Berlin: Gesundheitsladen.

Deiß, M. \& Heidling, E. (2001). Interessenvertretung und Expertenwissen. Anforderungen und Konsequenzen für Betriebsräte und Gewerkschaften. Düsseldorf: Hans-Böckler-Stiftung.

Fichter, M., Gester, J. \& Zeuner, B. (2004). Externe Herausforderungen - Interne Problemlagen Zukunftsoptionen: Eine internationale Perspektive. In P. Frerichs, W. Pohl, M. Fichter, J. Gerster \& B. Zeuner (Hrsg.). Zukunft der Gewerkschaften. Zwei Literaturstudien. Abgerufen von www.polsoz.fu-berlin.de/polwiss/forschung/oekonomie/gewerkschaftspolitik/materialien/HBS Zukunft/Fichter-Gester-Zeuner-HBS-Zukunft_044.pdf

Foucault, M. (1973). Die Geburt der Klinik. Eine Archäologie des ärztlichen Blicks. München: Carl Hanser.

GAL (Grün-Alternative Liste)-Umweltgruppe (1984). Dioxin in Hamburg. Verursacher, Verantwortliche, Betroffene. Hamburg: Ernst Kabel.

Hauch-Fleck, M.-L. (17. November 1989). Gefährliche Stoffe. Die Zeit, 47. Abgerufen von http://www.zeit.de/1989/47/gefaehrliche-stoffe/komplettansicht

Hien, W. (2017). Körper und Arbeit - Zu den Schattenseiten des Wirtschaftswunders. In Sozial.Geschichte Online, 21, 125-170. Abgerufen von http://duepublico.uni-duisburg-essen.de/servlets/DocumentServlet?id=44662

Illich, I. (1975). Die Enteignung der Gesundheit. „Medical Nemesis.“ Reinbek bei Hamburg: Rowohlt.

Kardorff, E. v. (2009). Kooperation, Koordination und Vernetzung. Anmerkungen zur Schnittstellenproblematik in der psychosozialen Versorgung. In B. Röhrle, G. Sommer \& F. Nestmann (Hrsg.), Netzwerkintervention - Fortschritte der Gemeindepsychologie und Gesundheitsförderung (S. 203-222). Tübingen: dgvt Verlag.

Kardorff, E. v. (1996). Die Gesundheitsbewegung - eine Utopie im Rückspiegel. In GesundheitsAkademie/Landesinstitut für Schule und Weiterbildung, NRW (Hrsg.), Macht. Vernetzung. Gesund? Strategien und Erfahrungen regionaler Vernetzungen im Gesundheitsbereich (S. 15-43). Frankfurt/M.: Mabuse-Verlag.

Kemper, C. (2016). Medizin gegen den Kalten Krieg. Ärzte in der anti-atomaren Friedensbewegung der 1980er-Jahre. Göttingen: Wallstein.

Köhler, B. M. (1983). Toxikologie und Arbeitsmedizin für den Arbeitsschutz. Werkstattbericht des Wissenschaftszentrums Berlin. Berlin: Eigendruck.

Kooperationsstelle Hamburg IFE (2017). Wissens-Datenbanken. Abgerufen von http://www.kooperationsstelle-hh.de/informationsangebote/?lang=de

Leisewitz, A. (1992). Ökologische Spurensuche im Betrieb. „Tatort Betrieb“. Erfahrungen einer Aktion der IG Metall. Frankfurt/M.: Ökologische Briefe.

Lienert, A. (2009). Das Beschwerdewesen für psychiatrische Patienten in Deutschland - Gesundheitspolitischer Kontext und empirische Untersuchung von Patientenfürsprechern und unabhängigen Beschwerdestellen (Dissertation.) Abgerufen von https://mediatum.ub.tum.de/doc/981790/981790.pdf

Meyer, M. (2010). The Rise of the Knowledge Broker. Science Communication, 32 (1), 118-127. doi: $10.1177 / 1075547009359797$

Moody, K. (1997). Workers in a Lean World. London: Verso.

Moritz, N. H. \& Travis, P. (2008). 8 Blickwinkel. USA: Original Film/Relativity Media.

Raehlmann, I. (2015). Entwicklung von Arbeitsorganisationen. Voraussetzungen, Möglichkeiten, Widerstände (2. Aufl). Wiesbaden: Springer VS.

Roth, R. \& Rucht, D. (Hrsg.). (2008). Die sozialen Bewegungen in Deutschland seit 1945. Frankfurt/M.: Campus. 
Rucht, D. (1993). Neue soziale Bewegungen. In U. Andersen, \& W. Wolke (Hrsg.), Handwörterbuch des politischen Systems der Bundesrepublik Deutschland (S. 363-367). Opladen: Leske + Budrich.

Rucht, D. \& Neidhardt, F. (2007). Soziale Bewegungen und kollektive Aktionen. In H. Joas (Hrsg.), Lehrbuch der Soziologie (S. 627-651). Frankfurt/M.: Campus.

Tratschin, L. (2016). Protest und Selbstbeschreibung. Selbstbezüglichkeit und Umweltverhältnisse sozialer Bewegungen. Bielefeld: transcript. doi: 10.14361/9783839436912

Ulich, E., Zink, K. J. \& Kubek, V. (2013). Das Menschenbild in Arbeitswissenschaft und Betriebswirtschaftslehre. Zeitschrift für Arbeitswissenschaft, 67 (1), 15-22. doi: 10.1007/BF03373899

Weick, K. E. (1985). Der Prozeß des Organisierens. Frankfurt/M.: Suhrkamp.

Windeler, A. \& Wirth, C. (2010). Netzwerke und Arbeit. In F. Böhle, G. Voss \& G. Wachtler (Hrsg.), Handbuch Arbeitssoziologie (S. 569-596). Wiesbaden: Springer VS.

doi: 10.1007/978-3-531-92247-8_19

Winter, R. (2017). Gesellschaftliche Konflikte, digitaler Widerstand und die Entstehung des Politischen. In H. Gummert, J. Henkel-Otto \& D. H. Medebach (Hrsg.). Medien und Kulturen des Konflikts. Pluralität und Dynamik von Generationen, Gewalt und Politik (S. 237-252). Wiesbaden: Springer VS. doi: 10.1007/978-3-658-16108-8_10

Wintersberger, H. (1978). Gesundheitskämpfe in Italien. Von der Arbeitsmedizin zur Arbeitermedizin. Argument Sonderband, 27, 151-163.

Wintersberger, H. (1988). Arbeitermedizin in Italien. Eine Kulturrevolution im Spannungsfeld von Arbeit und Gesundheit. Berlin: Edition Sigma. 